\title{
ATILA IAMARINO
}

\section{Análise e Caracterização Molecular, Estrutural e Populacional de Proteases de HIV-1 do Estado de São Paulo}

Tese apresentada ao Programa de PósGraduação em Microbiologia do Instituto de Ciências Biomédicas da Universidade de São Paulo, para obtenção do Título de Doutor em Ciências. 


\section{ATILA IAMARINO}

\section{Análise e Caracterização Molecular, \\ Estrutural e Populacional de Proteases de \\ HIV-1 do Estado de São Paulo}

Tese apresentada ao Programa de PósGraduação em Microbiologia do Instituto de Ciências Biomédicas da Universidade de São Paulo, para obtenção do Título de Doutor em Ciências.

Área de concentração: Microbiologia

Orientador: Prof. Dr. Paolo Marinho de Andrade Zanotto

Versão original

São Paulo

2012 
DADOS DE CATALOGAÇÃO NA PUBLICAÇÃO (CIP)

Serviço de Biblioteca e Informação Biomédica do

Instituto de Ciências Biomédicas da Universidade de São Paulo

reprodução não autorizada pelo autor

Iamarino, Atila.

Análise e caracterização molecular, estrutural e populacional de proteases de HIV-1 do Estado de São Paulo / Atila lamarino. -- São Paulo, 2012.

Orientador: Prof. Dr. Paolo Marinho Andrade Zanotto.

Tese (Doutorado) - Universidade de São Paulo. Instituto de Ciências Biomédicas. Departamento de Microbiologia. Área de concentração: Microbiologia. Linha de pesquisa: Vírus humanos.

Versão do título para o inglês: Molecular, structural and populational analysis and characterization of HIV-1 proteases at São Paulo state.

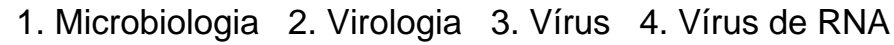

5. Retroviridade 6. HIV I. Zanotto, Prof. Dr. Paolo Marinho Andrade II. Universidade de São Paulo. Instituto de Ciências Biomédicas.

Programa de Pós-Graduação em Microbiologia III. Título. 
Candidato(a):

Título da Tese:

Orientador(a):
Atila lamarino.

Análise e caracterização molecular, estrutural e populacional de proteases de HIV-1 do Estado de São Paulo.

A Comissão Julgadora dos trabalhos de Defesa da Tese de Doutorado, em sessão pública realizada a .... considerou
( ) Aprovado(a)
( ) Reprovado(a)

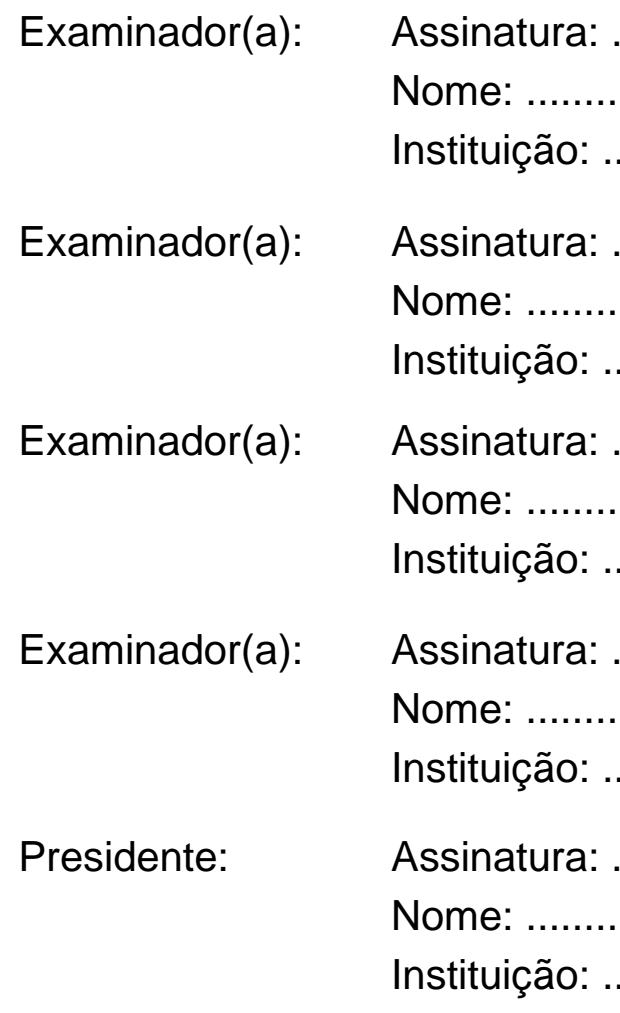


São Paulo, 16 de novembro de 2006.

\section{PARECER 757/CEP}

Prezado Senhor,

Atendendo sua solicitação, a Comissão de Ética em Pesquisas com Seres Humanos do $I C B$, em sua $70^{\text {a }}$ reunião realizada em 14.11.06, analisou o projeto de sua responsabilidade intitulado: "Análise e Caracterização Molecular, Estrutural e Biológica de Transcriptases Reversas de HIV-1 no Estado de São Paulo".

Informo a V.Sa. que, após análise e discussão, o referido projeto foi aprovado por esta Comissão.

Esclareço a V.Sa. que dentro de 12 meses, relatório do referido projeto deverá ser encaminhado à Secretaria deste CEP.

Atenciosamente,

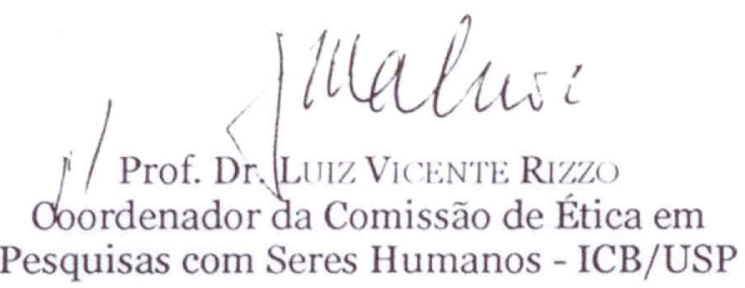

Ilmo. Sr.

ATILA LAMARINO

Departamento de Microbiologia

Instituto de Ciências Biomédicas -USP 
Decl. CEPSH. 024.12

informo que o titulo do Projeto foi alterado para "Análise e Caracterização Molecular, Estrutural e Populacional de Proteases de HIV-1 do Estado de São Paulo" não apresentando restrições quanto às modificações do projeto, que as mesmas não afetam os aspectos éticos da pesquisa.

São Paulo, 25 de junho de 2012.

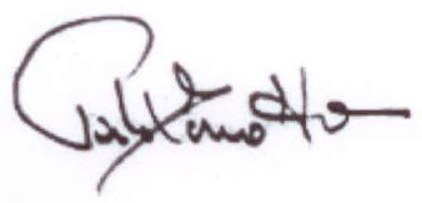

Prof. Dr. PAOlo M.A. ZanOtTO Coordenador da Comissão de Ética em Pesquisas com Seres Humanos - ICB /USP 
À minha esposa Paloma, pelo suporte, incentivo e apoio incondicional. Por estar sempre presente e pelo exemplo de esforço e compromisso.

Aos meus pais, por me darem a melhor formação que eu poderia ter. 


\section{AGRADECIMENTOS}

Ao meu orientador, Paolo Zanotto, pelo apoio incondicional não só ao projeto, mas ao meu crescimento intelectual, como pesquisador e cientista. Pela cobrança necessária. Pelo exemplo de pesquisa, busca de aprimoramento e da ciência acima de tudo. Tenho orgulho de ser mais um aluno do LEMB.

Aos amigos Frank, Camila, Ju Velasco, Coris e Carla por mostrarem do que um pesquisador competente é capaz, por estabelecerem um padrão de pesquisa impossível de ser alcançado, mas inspirador e norteador. Ao amigo Caio por mostrar que o que faz a diferença é a força de vontade e de caráter e o interesse em crescer. Tenho orgulho de ser mais um aluno do LEMB.

A todos os membros do LEMB, antigos e novos, por propiciarem um ambiente rico e desafiador, que me motivou e fez parte de meu desenvolvimento.

Ao pessoal da UFRJ , o professor Pedro Pascutti e os alunos Alan Wilter, Paulo Batista e Rosemberg Soares, ao pessoal do INCOR, o professor Paulo Oliveira e o aluno Tiago Sobreira, pelo apoio e ajuda com a dinâmica molecular.

Ao CNPq eà FAPESP pelo apoio financeiro. 


\section{RESUMO}

lamarino A. Análise e caracterização molecular, estrutural e populacional de proteases de HIV-1 do estado de São Paulo. [tese (Doutorado em Microbiologia)] São Paulo: Instituto de Ciências Biomédicas, Universidade de São Paulo; 2012.

Apesar dos esforços para controlar a infecção por HIV-1, na América do Sul, diversos recombinantes tem sido descritos, principalmente entre os subtipos B e F. Durante a tarefa coordenada de HIV-1 VGDN, foram encontrados diversos novos recombinantes BF no estado de São Paulo, sendo a maioria deles com a protease F. Técnicas filogenéticas usadas em integrases destes pacientes demonstraram que sequências recombinantes com perfis similares surgiram em diferentes eventos de recombinação. Análises filodinâmicas de amostras argentinas apontaram um crescimento contínuo de recombinantes com proteases $F$ após a introdução da terapia intensiva, enquanto o subtipo B deixou de crescer. Dados estruturais e de interação de proteases $\mathrm{F}$ resistentes com o inibidor nelfinavir obtidos por dinâmica molecular sugeriram que polimorfismos do subtipo $\mathrm{F}$ podem atuar como restauradores de atividade ou acentuar a perda de afinidade pelo inibidor. Um vetor recombinante pNL4-3 com parte do gene gag e a protease do subtipo $F$ foi construído, permitindo a comparação de seu efeito no fitness viral.

Palavras-chave: HIV. Protease do HIV-1. Evolução Molecular. Filogenia. Dinâmica Molecular. Recombinação. 


\begin{abstract}
Iamarino, A. Molecular, structural and populational analysis and characterization of HIV-1 proteases at São Paulo state. [PhD thesis (Microbiology)] São Paulo: Instituto de Ciências Biomédicas, Universidade de São Paulo; 2012.

Despite general efforts to control HIV-1 infections, many recombinants have been described among B and F subtype in South America. During the VGDN HIV task in São Paulo state, a large number of new BF recombinants was found, most of which harbor a subtype F protease. Phylogenetic analysis of integrase genes from these patients showed distinct origins for similar recombinant regions. Phylodynamic analysis suggested that after HAART introduction in Argentina BF recombinants with F protease depicted a sustained growth, while subtype B had diminished in growth.. Moreover, structural data from proteases after HAART introduction, while subtype B had diminished growth. Subtype F proteases structure and nelfinavir interaction measured by molecular dynamics suggested that polymorphisms of this subtype may restore enzyme activity or decrease even further inhibitor affinity. A pNL4-3 recombinant vector with most of gag gene and a protease of subtype $F$ was made, which allows the comparison of its effects on viral fitness.
\end{abstract}

Keywords: HIV. HIV-1 protease. Molecular Evolution. Phylogeny. Molecular Dynamics. Recombination. 


\section{SUMÁRIO}

IINTRODUÇÃO

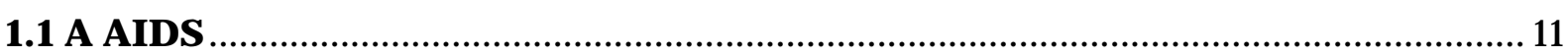

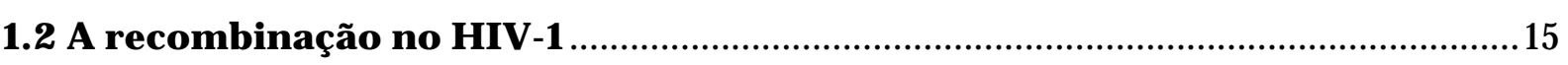

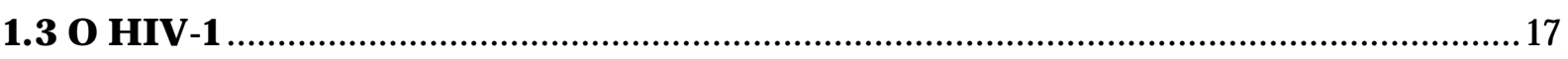

1.3.1 As proteínas de envelope e entrada na célula................................................................18

1.3.2 Desempacotamento e a transcrição reversa ......................................................................19

1.3.4 O complexo de integração e a integrase...................................................................... 22

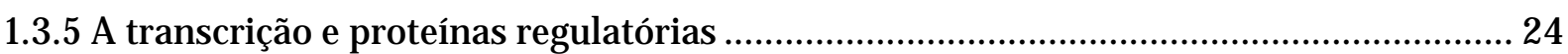

1.3.6 Montagem, brotamento e as proteínas derivadas de Gag..................................................27

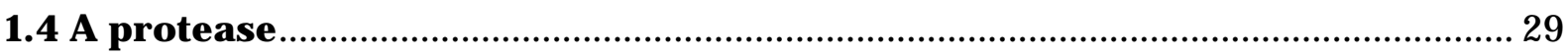

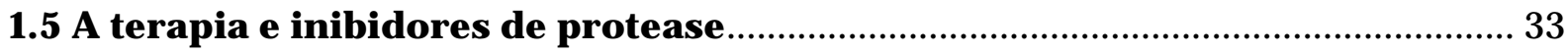

1.6 Outros alvos terapêuticos .................................................................................. 36

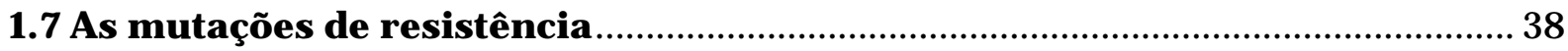

1.7.1 Mutações de resistência a inibidores de transcriptase reversa e integrase....................... 39

1.7.2 Mutações de resistência em protease e Gag...................................................................... 40

1.8 A Epidemia do estado de São Paulo e o projeto VGDN …………………………. 43

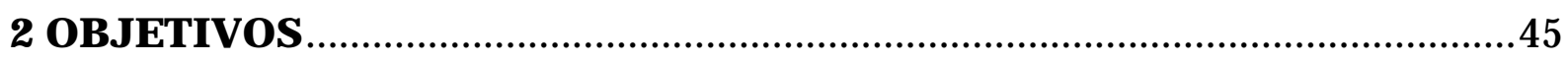

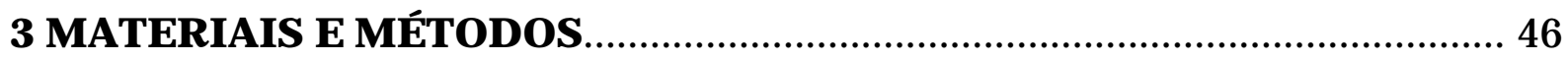

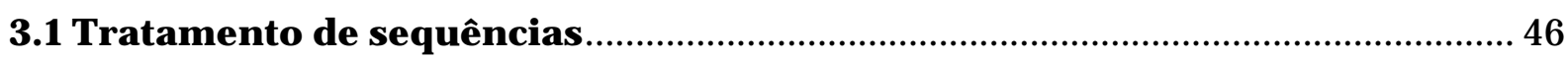

3.1.1 Subtipagem e análise dos perfis de recombinação ……………………………………..... 46

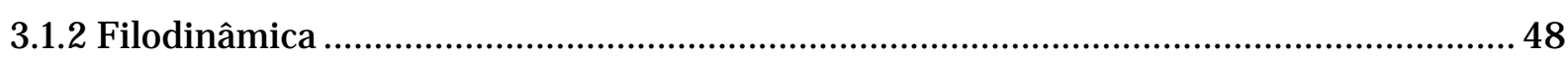

3.1.3 Estimativa de seleção e fitness ............................................................................... 50

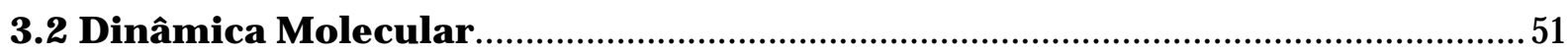

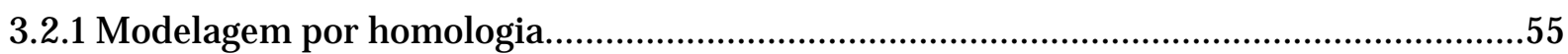

3.2.2 Interação Molecular ............................................................................................. 56

3.2.3 Mecânica Molecular ...............................................................................................57

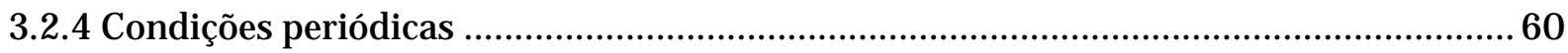

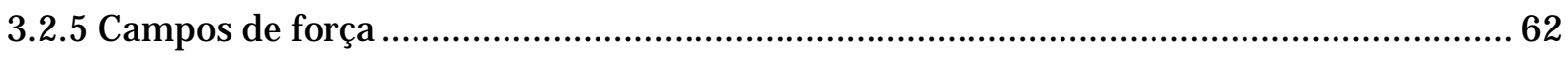

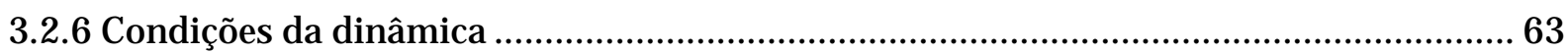

3.2.7 Energia livre de ligação e interação com o ligante ……………………………………..... 64

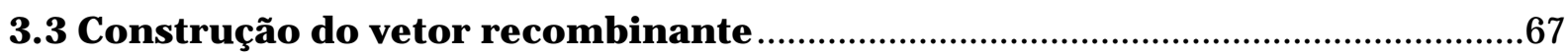

3.3.1 Digestão e ligação dos fragmentos amplificados e do plasmídeo cultivado .......................67 


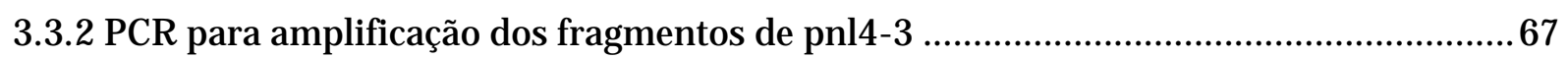

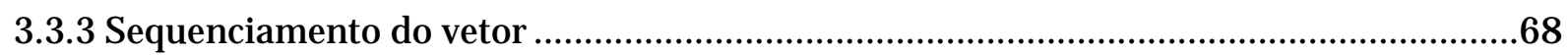

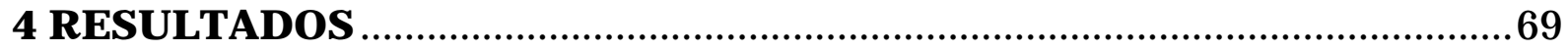

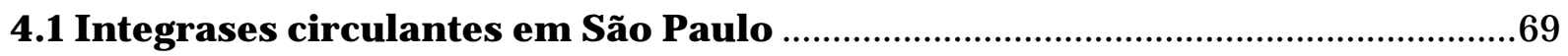

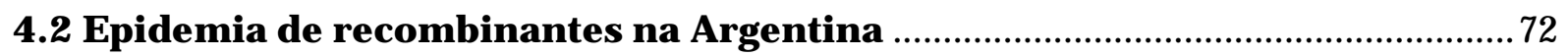

4.3 Dinâmica molecular de proteases B e F resistentes............................................ 74

4.4 Construção de um clone infeccioso de HIV-1 recombinante............................. 77

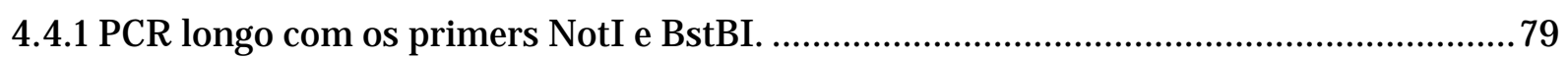

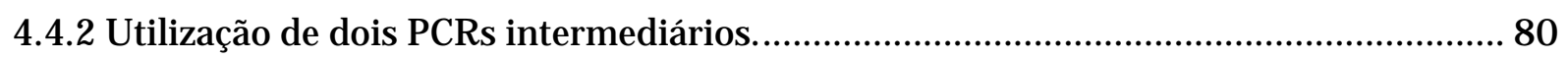

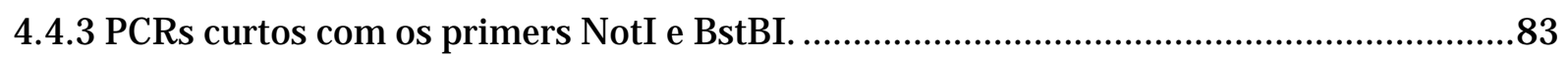

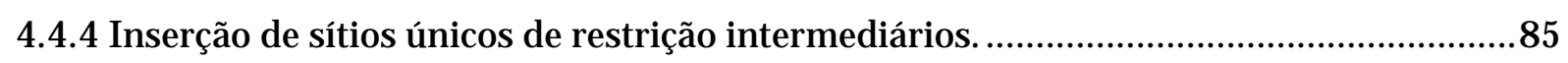

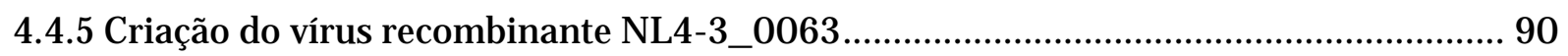

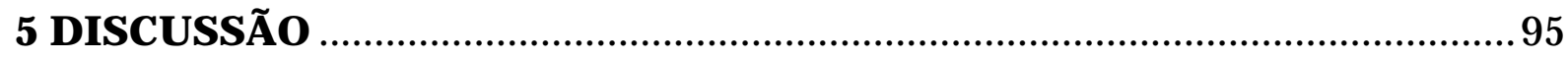

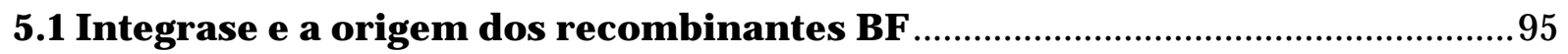

5.2 Crescimento diferencial de recombinantes portadores de protease $F$...........95

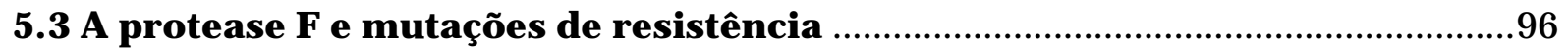

5.4 A importância da recombinação para o HIV ....................................................97

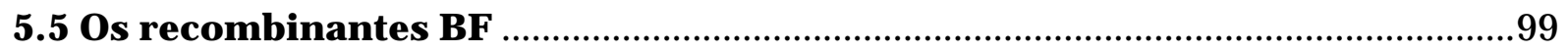

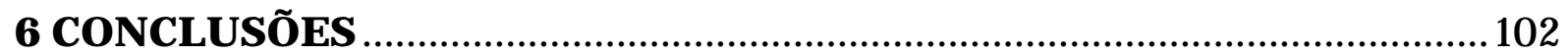

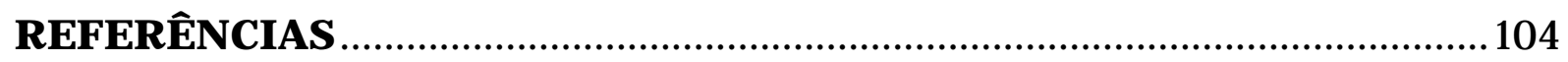

ANEXO A - Sequências das proteases modeladas e tratamento dos

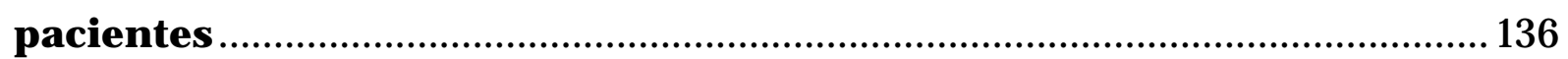

ANEXO B - Arquivos de entrada na Dinâmica Molecular ......................... 139

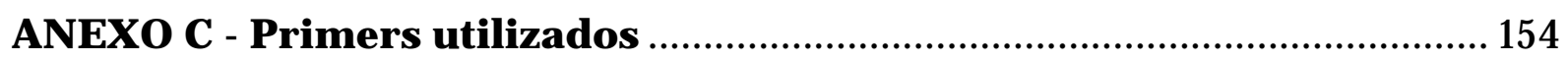

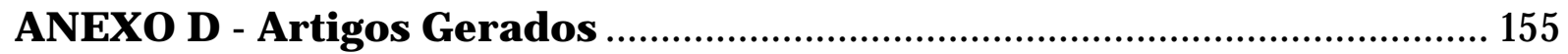

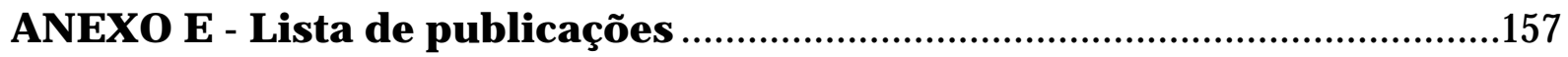




\section{INTRODUÇÃO}

\subsection{A AIDS}

No início da década de 1980, começaram a ser identificados nos Estados Unidos os primeiros casos de infecções oportunistas em adultos, casos de candidíase generalizada, citomegalovírus, pneumonia causada por Pneumocystis carinii e sarcoma a Kaposi, típicos em idosos e recém-nascidos imunocomprometidos (Gottlieb et al., 1981; Pneumocystis..., 1981). Estes casos de imunodeficiência ocorreram principalmente em dois grupos sociais, os gays e entre usuários de drogas injetáveis. Beneficiados pela mudança nos costumes da década anterior, o movimento gay estava em crescimento, e era comum o contato sexual desprotegido com múltiplos parceiros em um curto período de um ano (Garrett, 1995), algo que acabou se tornando essencial para explicar o rápido espalhamento início da epidemia fora da África.

Uma rede de contatos sexuais humana pode apresentar uma distribuição de parceiros que segue uma lei de potência (Liljeros et al., 2001), onde muitas pessoas fazem contato com pouquíssimos parceiros, e alguns indivíduos têm contanto com centenas ou mesmo milhares de parceiros ao longo da vida. Tais indivíduos altamente conectados atuam como verdadeiros hubs ligando diferentes pontos da rede, e sua chance de infecção por um micro-organismo que se espalhe através do contato sexual é diretamente proporcional ao número de ligações que eles estabelecem (PastorSatorras e Vespignani, 2001). Em situações onde o número de contatos é muito grande, quando o expoente a na distribuição cumulativa $\mathrm{P}(\mathrm{k}) \cong \mathrm{k}^{\mathrm{a}}$ para $\mathrm{k}$ parceiros é menor do que três, a chance de transmissão de qualquer doença sexualmente transmissível (DST) se aproxima de um (Newman, 2002). De fato, entre os gays de cidades como São Francisco, por exemplo, a prevalência de DSTs como a mononucleose e hepatite B, era significativamente maior que na população geral já na década de 1970 (Garrett, 1995).

Esta síndrome de imunodeficiência foi inicialmente definida como GRID (GayRelated Immunodeficiency Disease) devido à associação aos gays, mas com a descoberta de casos entre heterossexuais vindos da África e do Haiti, a doença passou a ser chamada de AIDS (Acquired ImmunoDeficiency Syndrome) ou Síndrome da 
Imunodeficiência Adquirida (SIDA) (Grmek et al., 1993). No Brasil, os primeiros casos de AIDS foram reportados em 1982, nos estados de São Paulo (8 casos) e Rio de J aneiro (3 casos) (Bello et al., 2006). Posteriormente, o primeiro caso foi traçado retrospectivamente para um paciente homossexual morto em São Paulo, em 1980 (Bello et al., 2006).

A distribuição de casos sugeria contágio sexual e sanguíneo, provavelmente causado por um agente infeccioso. E, pouco tempo depois, este agente foi isolado e caracterizado através de uma extensa e complicada colaboração entre dois laboratórios. No Instituto Pasteur de Paris, Luc Montagnier e seus alunos isolaram células de linfonodo do pescoço de um paciente com linfadenopatia, e amostra foi chamada de BRU (Montagnier, 2002). Assim, foi detectada a atividade de transcriptase reversa, e com o isolamento de um retrovírus foi possível saber que ele não era reconhecido por anticorpos anti-HTLV, tratando-se de um novo vírus da família lentiviridae nomeado LAV (Lymphadenopathy-Associated Virus) (BarreSinoussi et al., 1983).

Concomitantemente, nos EUA, Robert Gallo conseguiu isolar o HTLV-1 de alguns casos (2 de 33) de pacientes com AIDS, falhando em estabelecer a causa da doença (Gallo et al., 1983). O isolamento do retrovírus responsável por seu grupo ocorreu no ano seguinte, sob o nome de HTLV-3 (Popovic et al., 1984). Através do cultivo viral em células eternizadas que produziam mais partículas virais foi possível desenvolver o teste de bolsas de sangue (Schupbach et al., 1984) e mostrar efetivamente que o HTLV-3 era o causador da AIDS (Gallo et al., 1984). Com o sequenciamento genoma dos vírus LAV e HTLV-3, em 1985 (Marx, 1985), foi descoberto que ambos os isolados diferiam em menos de $2 \%$ dos nucleotídeos do envelope, e provavelmente se tratava de amostras obtidas de um mesmo paciente. A resolução se deu em 1993, quando a Roche demonstrou a pedido do instituto nacional de saúde americano (National Institutes of Health, $\mathrm{NIH}$ ) que o vírus original pertencia a um paciente francês (LAI), e havia contaminado a amostra BRU de Montagnier (Chang et al., 1993). Em 1986, o nome do novo retrovírus foi consolidado como vírus da imunodeficiência humana ou HIV (Human Immunodeficiency Virus) (Coffin et al., 1986).

A diversidade viral encontrada em pessoas vindas da África, muito maior do que a relativa homogeneidade entre amostras americanas e europeias, e a prevalência de casos em heterossexuais (Piot et al., 1984) indicaram uma epidemia mais bem 
estabelecida neste continente (Brun-Vezinet et al., 1984), sugerindo uma origem africana do HIV. Com a descoberta de um novo tipo de HIV na África ocidental, que passou a ser chamado de HIV-2 (Clavel et al., 1986), este cenário se mostrou ainda mais provável. Em pouco tempo, se viu que o HIV-2 era mais similar ao retrovírus símio (SIVmac) recém-isolado de macacos reso (Macaca mulatta) (Daniel et al., 1985) do que do HIV-1, o que indicava uma origem símia deste retrovírus. Esta associação foi reforçada com a descoberta $1 \mathrm{~m} 1989$ de um SIV (SIVcpz-gab1) similar ao HIV-1 (Peeters et al., 1989). No mesmo ano, se viu que o HIV-2 tinha como origem o SIV de macaco mangabei (Cercocebus atys) (Hirsch et al., 1989), primata do qual saltou pelo menos oito vezes para humanos (Tebit e Arts, 2011). A busca por SIVs em primatas e por novas linhagens de HIV entre humanos na África acabou revelando um cenário complexo e com diferentes saltos de símios para humanos (Figura 1). Mais de 30 espécies de símios africanos possuem SIVs próprios (Tebit e Arts, 2011).

Quanto ao HIV-1, ele atualmente é classificado em quatro grupos: M (main) e N (new) originados em dois eventos de transmissão para humanos (Gao et al., 1999; Sharp et al., 2001), O (outlier) (Robertson et al., 2000) e o recentemente proposto $\mathrm{P}$ (Plantier et al., 2009), ambos provavelmente derivados do SIV de gorilas (Gorilla gorilla) (Van Heuverswyn et al., 2006). Os grupos O, N, e P são responsáveis por menos de $5 \%$ das infecções em todo o mundo (Lal et al., 2005). Já o grupo M, mais prevalente, pode ser dividido em diferentes subtipos (A-D, F-H, J e K) (Robertson et al., 2000) e tem uma origem estimada para o começo do século XX, entre 1884 e 1924 (Sharp e Hahn, 2008). Além dos subtipos, são reconhecidas 51 formas circulantes recombinantes ou (Circulating Recombinant Forms, CRFs [http:/ / www.hiv.lanl.gov/ ]), vírus derivados do evento de recombinação de dois ou mais subtipos diferentes encontrados em mais de três indivíduos sem relação epidemiológica. 
Figura 1- Eventos de formação das linhagens de HIV

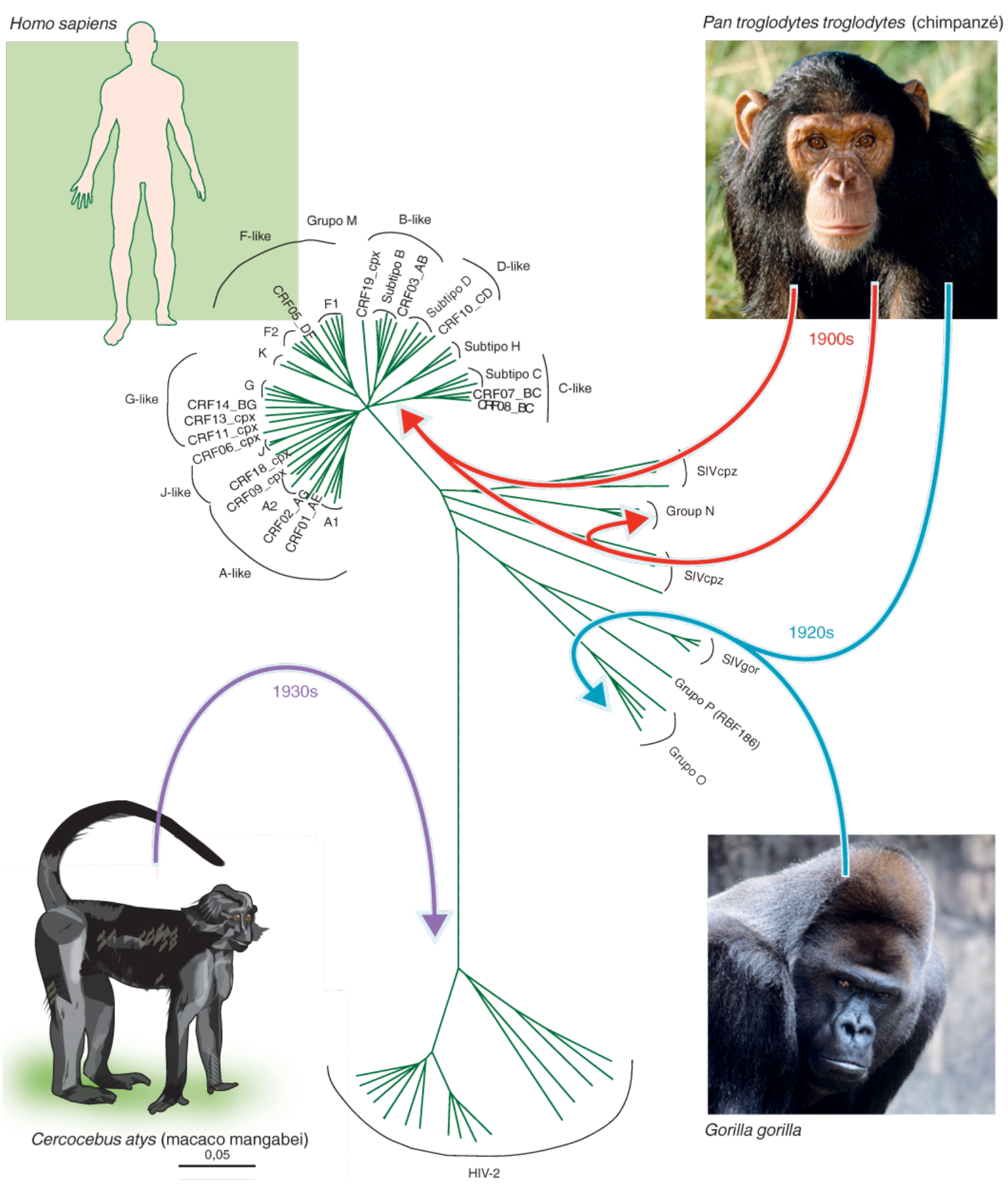

Os saltos de diferentes linhagens de SIV de outros primatas para humanos e grupos de HIV formados a partir deles, com a consequente diversidade genética.

Fonte: Modificado de Tebit e Arts (2011). Com permissão.

Até o momento, o HIV já causou mais de 600 mil casos de AIDS no Brasil (Ministério da Saúde do Brasil, 2011), e já são mais de 33 milhões de infectados no mundo (J oint United Nations Programme on HIV/ AIDS, World Health Organization, 2010). 


\subsection{A recombinação no HIV-1}

De maneira similar aos EUA e Europa, os primeiros casos de HIV no Brasil ocorreram em grandes centros urbanos, principalmente entre homens que fazem sexo com homens (HSHs), causados pelo subtipo B (Morgado et al., 2002). Mas, diferentemente de Estados Unidos e Europa, na década de 1990 surgiram as primeiras sequências discordantes. O subtipo F, inicialmente descrito no Gabão, passou a ser encontrado no Brasil (Louwagie et al., 1993; 1994), e posteriormente na Argentina (Aulicino et al., 2011). Em pouco tempo formas recombinantes BF passaram a ser descritas (Sabino et al., 1994), e a primeira CRF BF, a CRF12_BF foi descrita em 2001 na Argentina (Carr et al., 2001). As reconstruções filodinâmicas apontam para uma entrada anterior do subtipo B, ao fim da década de 1960 (Bello et al., 2006, 2007), seguido na próxima década do subtipo $F$ (Aulicino et al., 2007) e do surgimento da CRF12_BF (Dilernia et al., 2011).

Os recombinantes aumentam em frequência no Brasil desde então. Embora atinjam menores proporções em cidades com epidemias mais antigas e bem estabelecidas, em localidades onde a epidemia é mais recente ou dinâmica, já chegam a quase 30\% dos novos casos (de Souza et al., 2008; Teixeira et al., 2010). Em Santos, por exemplo, recombinantes $\mathrm{BF}$ foram identificados em metade dos casos de infeç̧ões atuais (Sucupira et al., 2007b). Na Argentina, a expansão dos recombinantes $\mathrm{BF}$ foi muito mais acentuada, dividida em duas epidemias, uma causada pelo subtipo B em HSHs, e outra causada pelos recombinantes BF em usuários de drogas injetáveis (UDIs) e heterossexuais (Avila et al., 2002). Desde 1996, os UDIs e heterossexuais passaram a constituir o maior grupo de risco (Rossi et al., 2006), e o crescimento dos recombinantes foi um dos maiores registrados para o HIV-1 (Aulicino et al., 2007), gerando novas formas recombinantes e chegando a 85\% dos casos de infecção infantil (Aulicino et al., 2011).

A epidemia brasileira e a argentina também diferem nos recombinantes BF mais importantes. Enquanto na Argentina ainda predominam variantes derivadas da CRF12_BF com linhagens definidas (Aulicino et al., 2011), o Brasil possui diversas CRFs com origens distintas (Thomson et al., 2004), e muita diversidade de URFs (Brindeiro et al., 1999; Tanuri et al., 1999; Vicente et al., 2000; Sa Filho et al., 2005, 2006; Sanabani et al., 2006; Guimaraes et al., 2010). Ao contrário de CRFs mais bem estabelecidas, que causam grandes epidemias bem definidas, como as CRF01_AE e 
CRF02_AG (Carr et al., 1996, 1998; Gao et al., 1996; Tebit e Arts, 2011), os recombinantes $\mathrm{BF}$ compõe diversas $\mathrm{CRFs}$ com múltiplos pontos de quebra. E muitas sequências classificadas como CRF_BF são URFs com pontos de quebra discordantes erroneamente classificadas (Zhang et al., 2010). Das 51 CRFs registradas até o momento, 11 são recombinantes $\mathrm{BF}$, das quais 5 são encontrados no Brasil (CRF28, CRF29, CRF39,CRF40 e CRF46) (De Sa Filho et al., 2006; Guimaraes et al., 2008; Sanabani et al., 2010). Das demais, duas ocorrem na Argentina (CRF12_BF e CRF17_BF) (Carr et al., 2001; Delgado et al., 2010), duas no Uruguai (CRF12_BF e CRF38_BF) (Carr et al., 2001; Ruchansky et al., 2009), uma no Chile (CRF44_BF) (Delgado et al., 2010) e duas na Europa (CRF42_BF, CRF47_BF) (Fernández-García et al., 2010). Nos outros países da América do Sul, circulam BFs derivados destas CRFs (Hierholzer et al., 2002; Sierra et al., 2005; Guimaraes et al., 2012).

A recombinação em HIV é dependente de uma série de eventos em seu ciclo replicativo, e recombinantes inter-subtipos dependem antes de tudo de uma coinfecção (dois vírus distintos em um intervalo de tempo próximo) ou superinfecção (uma segunda infecção por outro subtipo em recipiente com infecção já estabelecida) do paciente por mais de um subtipo. Do acompanhamento de pacientes recéminfectados, se viu que a chance de superinfecção chega a 5\% (Smith et al., 2004; Chohan et al., 2005; Lavreys et al., 2006), um valor muito próximo da chance de infecção primária em grupos de risco (Harro et al., 2004; Smith et al., 2005), indicativo de que a resposta imune provê pouca ou nenhuma barreira contra o vírus (Piantadosi et al., 2007), favorecendo eventos de recombinação em uma infecção crônica. Eventos de co-infecção e superinfecção seguidos de recombinação podem ocorrer até em progressores lentos (Casado et al., 2007) e controladores de elite (Clerc et al., 2010), mesmo 5 anos após a seroconversão (Piantadosi et al., 2007).

J á foram descritos casos de pacientes infectados por HIV-1 de diferentes grupos (Heyndrickx et al., 1996; Takehisa et al., 1997), diferentes subtipos (J anini et al., 1996, 1998) ou do mesmo subtipo (Zhu et al., 1995). No caso dos recombinantes BF, ainda em 1995, foram detectados pacientes co-infectados por mais de um subtipo no Brasil, entre eles os subtipos B e F, mas não foi possível diferenciar entre um evento de co-infecção ou superinfecção (Pieniazek et al., 1995).

No paciente com mais de uma linhagem viral, uma mesma célula precisa ser coinfectada e sofrer a integração de mais de um provírus diferente. Embora o HIV-1 seja capaz de induzir a retirada do receptor CD4 da superfície celular, mecanismo que 
evitaria a co-infecção, múltiplos provírus podem ser encontrados em uma mesma célula (Gratton et al., 2000), em até 3 ou 4 cópias por núcleo (J ung et al., 2002). Tal frequência pode ocorrer devido à infecção celular através das sinapses virológicas entre uma célula infectada e outra sadia, que permite a transmissão eficaz de múltiplas partículas virais simultaneamente (Del Portillo et al., 2011). Após a coinfecção da célula, dois genomas distintos devem ser incorporados na partícula nascente, algo bastante comum na encapsidação do HIV (Onafuwa-Nuga e Telesnitsky, 2009). Esta partícula heterogênea precisa infectar uma nova célula onde, durante a retrotranscrição, a transcriptase reversa (RT) salta de um genoma para outro, produzindo um provírus composto de fragmentos dos diferentes genomas originais (Hu e Temin, 1990; Stuhlmann e Berg, 1992; Galetto e Negroni, 2005).

\subsection{HIV-1}

O HIV-1 é um retrovírus envelopado (Figura 2), com uma partícula esférica de diâmetro entre 125 e 145 nm (Briggs et al., 2003; 2006) mantida neste formato por uma matriz composta da proteína MA (p17, matrix) derivada da poliproteína Gag. Seu capsídeo maduro tem um formato cônico, e é composto de cerca de 1500 subunidades da proteína CA (p24, capsid) organizadas em cerca de 250 hexâmeros fechados acima e abaixo por 12 pentâmeros ( 5 na porção mais fina e 7 na mais larga) (Li et al., 2000a). Dentro deste capsídeo estão duas cópias de seu genoma de RNA fitas simples de cerca de 9200 bases envolvidas pelas subunidades NC (p7, nuclocapsid) de Gag (Morellet et al., 1998). 


\section{Figura 2 - Partícula do HIV}

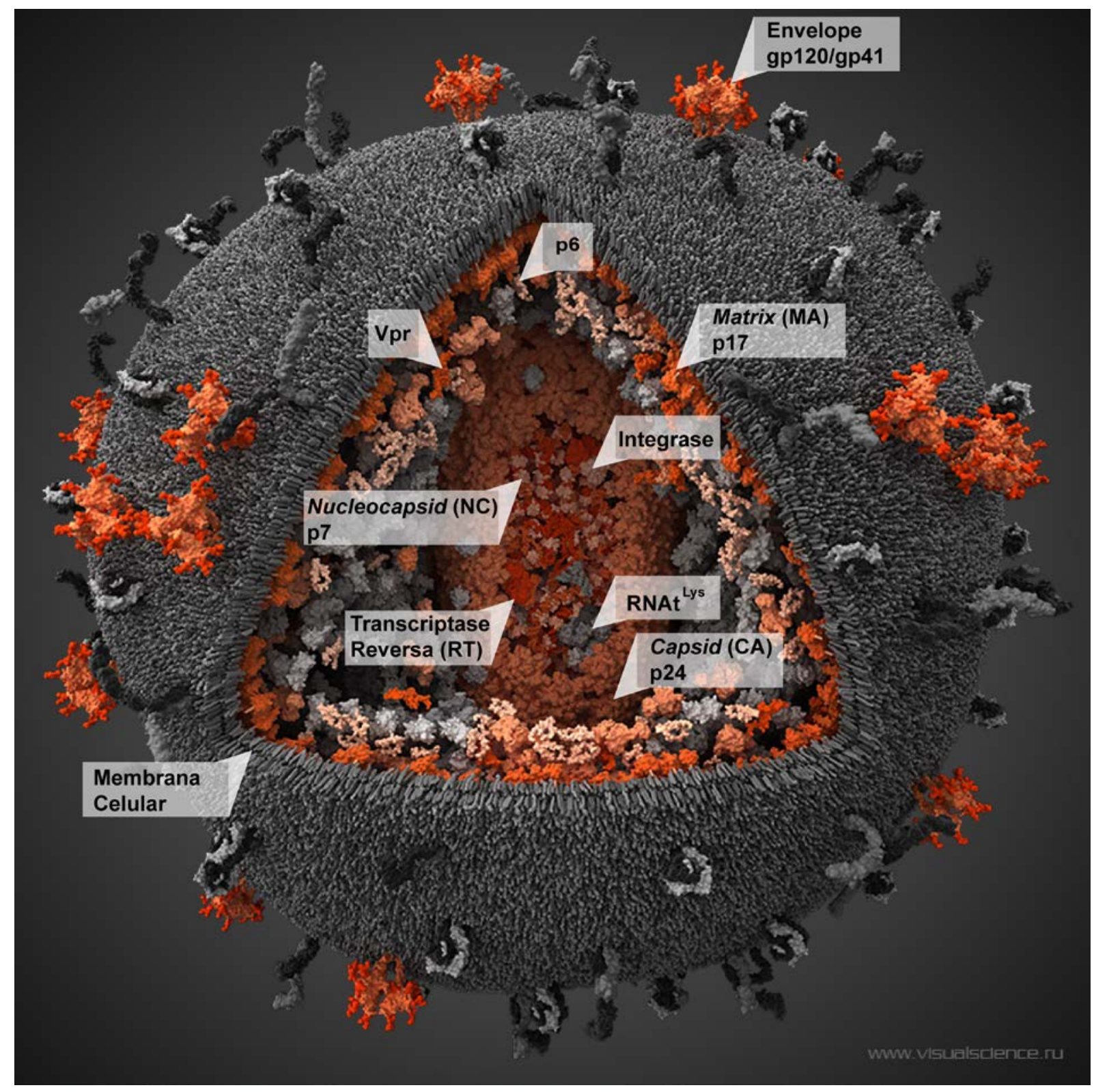

Fonte: Modificado de Visual Science (2010-2012). Com permissão. CVisual Science

\subsubsection{As proteínas de envelope e a entrada na célula}

Processo de ligação e entrada do vírus na célula é uma etapa fundamental do ciclo viral. Dissolvida no envelope viral está glicoproteína gp160 do HIV, glicosilada e clivada dentro do retículo endoplasmático rugoso em duas subunidades, a subunidade transmembrânica gp41 e a subunidade de superfície gp120, que permanecem associadas não covalentemente uma à outra, organizadas em trios na membrana viral (Gallo et al., 2003). Os carboidratos adicionados no retículo facilitam a evasão do sistema imune pela proteína de superfície, mais exposta a anticorpos 
(Reitter et al., 1998). Embora o HIV também possa entrar na célula através do mecanismo de endocitose dependente de clatrina e da fusão direta com a membrana plasmática, e a importância de cada uma das vias ainda não está clara (Permanyer et al., 2010), o reconhecimento celular pelo envelope é o maior determinante do tropismo viral. A subunidade gp120 é responsável pelo reconhecimento do receptor CD4 e um co-receptor (Feng et al., 1996), um entre vários receptores de citocina, mais comumente CXCR4 ou CCR5 (Choe et al., 1996; Deng et al., 1996; Dragic et al., 1996). Sua ligação ao receptor expõe o sítio de ligação do co-receptor (Rizzuto et al., 1998), seguida da mudança conformacional da subunidade gp41, que se liga à membrana celular e promove a fusão entre as duas camadas lipídicas (Chan e Kim, 1998), promovendo a entrada do vírion na célula (Pierson et al., 2004). O HIV-1 coencapsida duas fitas de RNA positivo de aproximadamente 9,8 kb, com duas regiões promotoras (LTR, long terminal repeats).

\subsubsection{Desempacotamento e a transcrição reversa}

Assim que o HIV entra na célula, têm início dois processos complexos e concomitantes: o desempacotamento viral e a transcrição reversa. Ainda não está clara a dinâmica espaço-temporal do desempacotamento (Arhel, 2010). Uma das hipóteses propõe que o desempacotamento se dá imediatamente após a fusão do vírus com a membrana plasmática, e a transcrição reversa se dá em seguida, no citoplasma (Lehmann-Che e Saib, 2004; Suzuki e Craigie, 2007). Outra sugere um desempacotamento gradual, em paralelo à transcrição reversa e o transporte para o núcleo (McDonald et al., 2002; Warrilow et al., 2009). Por último, também se propõe que o desempacotamento ocorre apenas na membrana nuclear, depois da transcrição reversa completa, e somente seu término determina a desorganização do capsídeo (Klarmann et al., 1993).

A proteína celular TRIM5 $\alpha$ é capaz de reconhecer o capsídeo de retrovírus e promover o desempacotamento precoce, abortando a transcrição reversa (Stremlau et al., 2006; Black e Aiken, 2010). O que demonstra a importância de um capsídeo íntegro para a formação do DNA viral de dupla fita, mantendo um ambiente com moléculas importantes como NC, trascriptase reversa, integrase (IN), Vpr e o transportador RNAtLys trazido da célula anteriormente infectada (Ott, 2008) (Figura 
2). Não à toa, tanto TRIM5 $\alpha$ quando a Gag viral possuem marcas genéticas de uma longa batalha coevolutiva (J ohnson e Sawyer, 2009).

Quem sintetiza o cDNA viral é a enzima transcriptase reversa, uma polimerase de DNA capaz de utilizar como molde os dois tipos de substrato, tanto DNA quando $\mathrm{RNA}$, além de ter atividade de RNase $\mathrm{H}$. Ela consiste em um heterodímero de subunidades assimétricas, uma de 560 (p66) e outra de 440 aminoácidos (p51) (Kohlstaedt et al., 1992). A subunidade p66 possui o domínio de RNase H que corresponde à região que não está presente em p51, e os outros quatro domínios são relacionados à atividade de polimerase. Por sua estrutura semelhante a uma mão os domínios são chamados de: connection (conexão), que faz a ligação com a região da RNase $\mathrm{H}$, palm (palma) que se liga à fita de ácido nucléico, fingers (dedos) e thumb (dedão) que estão relacionados com a incorporação de novos nucleotídeos e ligação do primer (Kohlstaedt et al., 1992; Huang et al., 1998). A subunidade p51 é formada pelos mesmos aminoácidos e também possui os 4 domínios, mas sua estrutura é bem mais fechada e ela é inativa, provendo apenas apoio estrutural (Wang et al., 1994). 
Figura 3 - Representação esquemática da transcrição reversa.

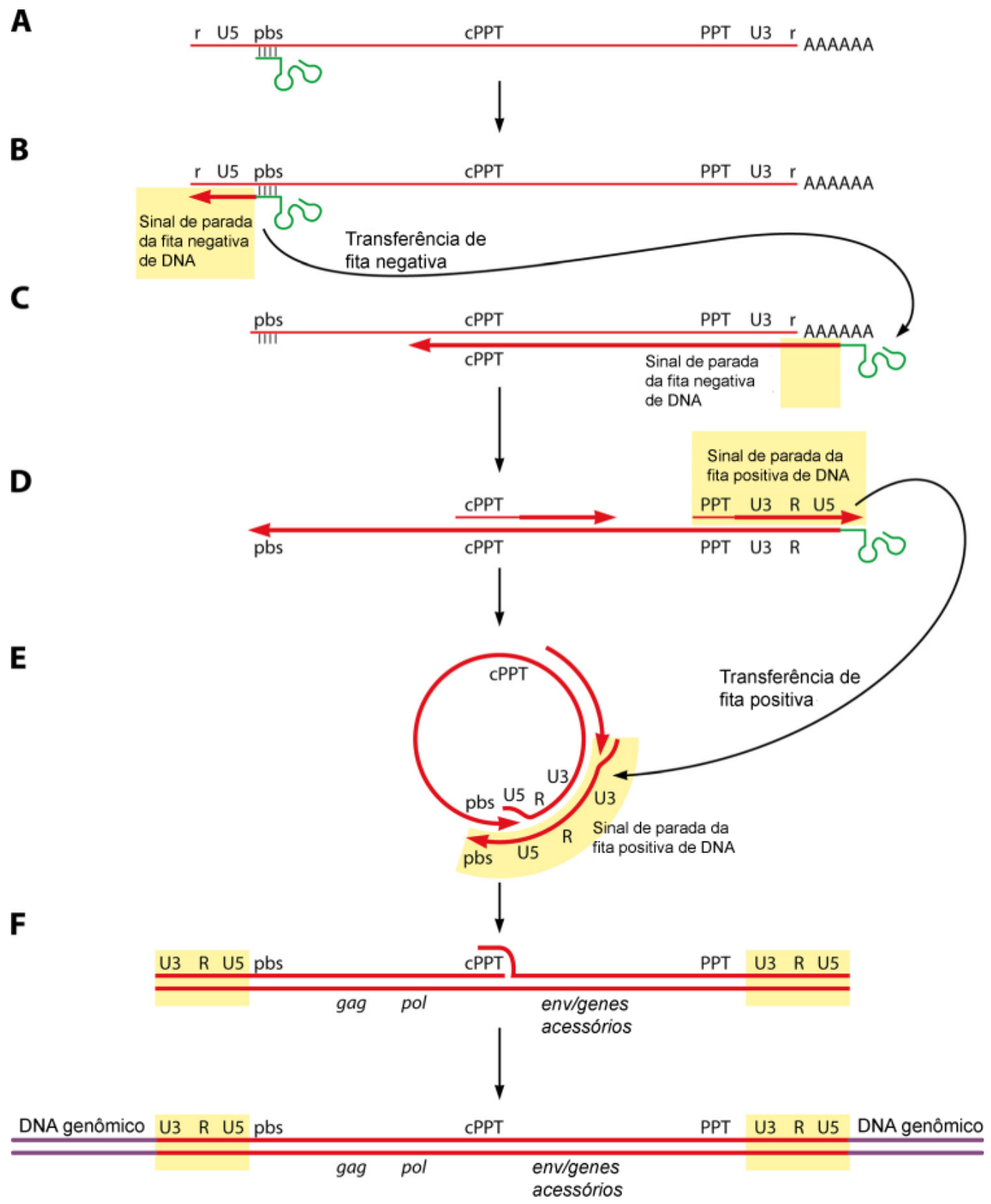

A - ligação do RNAt ${ }^{\mathrm{Lys}}$ ao genoma viral. B - Síntese da primeira porção genômica. C - Salto de fita molde e síntese da fita negativa. D - Síntese da fita complementar a partir dos PPTs. E - Sobreposição de fitas e síntese da LTR 5’. F - Degradação do iniciador de PPT e integração do provírus no DNA genômico do hospedeiro.

Fonte: Modificado de Onafuwa-Nuga e Telesnitsky (2009). Com permissão.

A transcrição reversa (Figura 3) tem início com a ligação de um iniciador de cadeia, o RNAtLys ao sítio complementar PBS (primer binding site) localizado no inicio do genoma viral, próximo à região repetitiva (LTR, long terminal repeats) da porção 5' (Figura 3A). Durante esta primeira etapa, apenas a porção inicial do genoma é sintetizada, do sítio PBS ao início da LTR 5’, ao mesmo tempo em que a RNase H degrada o genoma (RNAg) molde (Figura 3B). Na próxima etapa, a porção 
LTR 5' se liga à região complementar LTR 3' ao final do RNAg e a síntese da fita negativa de DNA prossegue até o sítio PBS, que agora representa o final do genoma (Figura 3C). A RNase H degrada novamente o RNAg, com exceção de duas regiões PPTs (polypurine tract), que servem de iniciadores da cadeia positiva e complementar de DNA (Figura 3D). A região LTR 5', perdida ao se ligar à LTR 3' e iniciar a síntese da fita complementar, é recuperada com a sobreposição da porção PBS da fita nascente (Onafuwa-Nuga e Telesnitsky, 2009) (Figura 3E). As duas etapas de transferência de fita, durante a ligação da LTR 5' de DNA com a LTR 3' complementar (Figura 3B), e a síntese da fita complementar (Figura 3D), provocam paradas de síntese e saltos de fita molde especialmente propícios à recombinação (Temin, 1993).

Outra proteína celular capaz de abortar a infecção viral durante este estágio é a APOBEC3G/ F (apolipoprotein B mRNA-editing enzyme-catalytic polypeptide-like). Esta citidina deaminase celular reconhece fitas simples de DNA no citoplasma, deaminando desoxicitidinas para desoxiuridinas, mutando citosinas em uracilas, o que promove a degradação do DNA e a hipermutação de $\mathrm{G} \rightarrow \mathrm{A}$ na dupla fita resultante. Este mecanismo de imunidade inata foi descoberto através da restrição da replicação do HIV-1 sem a proteína acessória Vif (viral infectivity factor) em determinadas linhagens traçada aos genes da família APOBEC (J armuz et al., 2002; Sheehy et al., 2002). A proteína Vif, carregada dentro do capsídeo viral (Liu et al., 1995), impede a incorporação da APOBEC3G no vírion nascente e promove sua posterior degradação (Goila-Gaur e Strebel, 2008), permitindo a ligação do RNAt ${ }^{\mathrm{Lys}} \mathrm{e}$ a transcrição reversa (Guo et al., 2006). Assim como outros mecanismos de imunidade inata, como TRIM5 $\alpha$ e Gag, Vif e as APOBECs também estão sujeitas à coevolução entre primatas e retrovírus (Meyerson e Sawyer, 2011).

\subsubsection{O complexo de integração ea integrase}

A integração ocorre de maneira única nos lentivírus, uma vez que estes são capazes de se replicar em células que não estão em divisão (Weinberg et al., 1991), e por isso o genoma viral precisa atravessar a membrana nuclear. Quem coordena este processo é a integrase, a última proteína codificada pelo gene Pol. Ela é formada por três domínios, um domínio N-terminal (NTD, N-terminal domain) com resíduos de histidina e cisteína que interagem com um átomo de zinco necessário para a ligação 
ao DNA, um domínio catalítico (CCD, catalytic core domain) que realiza a integração, e um domínio C-terminal (CTD, C-terminal domain) que se liga ao DNA de forma inespecífica (Krishnan et al., 2010). Os resíduos Asp116, Asp64 e Glu152 formam o sítio ativo e são necessários para o correto posicionamento do grupo $\mathrm{OH}$ do DNA alvo e dos íons 2+ $\left(\mathrm{Mg}^{2+}\right.$ e $\left.\mathrm{Mn}^{2+}\right)$ necessários para a quebra da fita (Krishnan et al., 2010). Ela possui duas atividades, uma de processamento da extremidade 3' do DNA e outro de transferência de fita, e sua ação dentro do núcleo depende da entrada do complexo pré-integração (PIC, pre-integration complex) (Maertens et al., 2010).

O PIC se forma logo após a transcrição reversa e está intimamente associado a ela devido à interação entre a integrase e a transcriptase reversa (Engelman, 2010). Ele se dirige para o núcleo durante o desempacotamento por um mecanismo dependente de actina e microtúbulos (Arhel et al., 2006). Associadas ao complexo, além do DNA viral e da integrase, estão as proteínas MA, Vpr e fatores celulares (Suzuki e Craigie, 2007). Com tantos componentes, o genoma do HIV de 3,3 $\mu \mathrm{m}$ é empacotado em um PIC de 56 nm (Miller et al., 1997), enquanto as moléculas que atravessam o poro nuclear por difusão passiva precisam ter um tamanho menor do que 9 nm (Mattaj e Englmeier, 1998), e sua entrada depende da ação das proteínas Vpr e CA (Lee et al., 2010) e da carioferina TNPO3 (Brass et al., 2008).

Vpr (viral protein R) é uma proteína viral incorporada dentro da partícula durante o empacotamento por se associar ao domínio p6 de Gag (Kondo et al., 1995). Bastante conservada entre HIV e SIV, ela não possui homólogos fora dos Lentivírus (Tristem et al., 1998), e é capaz de paralisar o ciclo celular no final da fase G2 e impedir a apoptose (Le Rouzic e Benichou, 2005), promovendo a importação do PIC, associando-se a porinas e importinas nucleares na membrana externa do núcleo (Suzuki e Craigie, 2007).

Para completar a integração, o DNA viral precisa se associar a dois dímeros de integrase, sendo que uma subunidade de cada dímero reconhece uma ponta do genoma, formando o intassomo. Apenas recentemente a estrutura do intassomo foi reconhecida (Hare et al., 2010; Maertens et al., 2010), o que permitiu um melhor entendimento do mecanismo de inserção do provírus (Cherepanov et al., 2011). O domínio catalítico das duas subunidades de integrase ativas age na porção 3’ de uma LTR, clivando o dinucleotideo C-A e expondo o fosfato 5', que será inserido no cromossomo hospedeiro. A outra extremidade do genoma viral é reconhecida por enzimas de reparo celulares e ligada à fita complementar (Cherepanov et al., 2011). 
Esta integração tende a ocorrer em sítios com transcrição ativa (Ciuffi, 2008) principalmente por causa da associação da integrase ao fator de crescimento ligante de cromatina LEDGF/p75 (Engelman e Cherepanov, 2008).

\subsubsection{A transcrição e proteínas regulatórias}

Uma vez integrado em uma porção transcricionalmente ativa do genoma, a transcrição do HIV começa por ação do promotor U3 localizado na LTR. A LTR viral atua como uma unidade de transcrição eucariótica, e contém elementos promotores como TATA box e sítios Sp1 (Taube et al., 1999) que recrutam o complexo de transcrição e a RNA polimerase II. Normalmente, a transcrição não cobre o genoma completo do HIV, são formados apenas transcritos curtos de cerca de $2 \mathrm{~kb}$ que dão origem a proteínas regulatórias como Tat e Rev, e acessórias como Nef (Wu, 2004) (Figura 4). Parte destes transcritos pode ser formada antes da integração do provírus, como demonstrado por vírus com a integrase defectiva que ainda produziam partículas viáveis (Engelman et al., 1995).

Nef (Negative Regulatory Factor) é uma pequena proteína sem função enzimática mas com atividade pleiotrópica, capaz de interferir em diversas vias de sinalização celulares. Ela promove a degradação do receptor CD4, o que diminui a concentração dessa proteína na superfície celular e possivelmente evita a superinfecção celular através da via dependente de endocitose (Garcia e Miller, 1991; Lundquist et al., 2002). Da mesma forma, Nef também promove a internalização e degradação do complexo de histocompatibilidade de classe I (MHC I) (Schwartz et al., 1996) ao reconhecer sua porção intracelular (Wonderlich et al., 2008), diminuindo as chances de uma resposta citotóxica contra a célula infectada (Collins et al., 1998). Por fim, ele é capaz de promover a ativação de linfócitos T (Simmons et al., 2001), e com isso aumentar a infectividade viral (Luo et al., 1997).

Tat (transcription trans-activator) é uma pequena proteína regulatória composta por entre 86 e 101 aminoácidos, que contém um domínio de ativação e ligação a cofatores e outro domínio (este básico) com um sinal de importação nuclear capaz de se ligar a RNA, e é necessária para a elongação do tamanho dos transcritos do provírus (Strebel, 2003). Ela é capaz de reconhecer as moléculas de RNA nascentes através da região responsiva TAR (trans-activation response) e recrutar uma quinase celular capaz de fosforilar a RNA polimerase II, promovendo a 
elongação e poliadenilação dos transcritos (Wei et al., 1998), e aumentando sua própria expressão (Charnay et al., 2009).

O HIV-1, assim como muitos outros vírus, precisa de uma forma de produzir transcritos diferentes a partir de um mesmo genoma. Enquanto os transcritos menores são prontamente exportados e traduzidos, os RNAs completos ou quase completos gerados por ação da Tat necessitam da ligação da proteína regulatória Rev (regulator of expression of virion proteins) (Cullen, 2003). Rev reconhece e se associa ao elemento responsivo RRE (Rev responsive element) localizado na região codante do gene env, e ao fator de exportação nuclear CRM1 para sair do núcleo (Daugherty et al., 2010b). Sua ligação ao RNA se dá de forma cooperativa, montando dímeros que se associam em um multímero crescente (Daugherty et al., 2010a) e promovendo a exportação nuclear de transcritos maiores, com cerca de 4 e $9 \mathrm{~kb}$ (Pollard e Malim, 1998) (Figura 4). 
Figura 4 - Transcritos do genoma do HIV-1 sem e com a regulação promovida por Rev.

Fase Inicial (sem/pouco Rev)

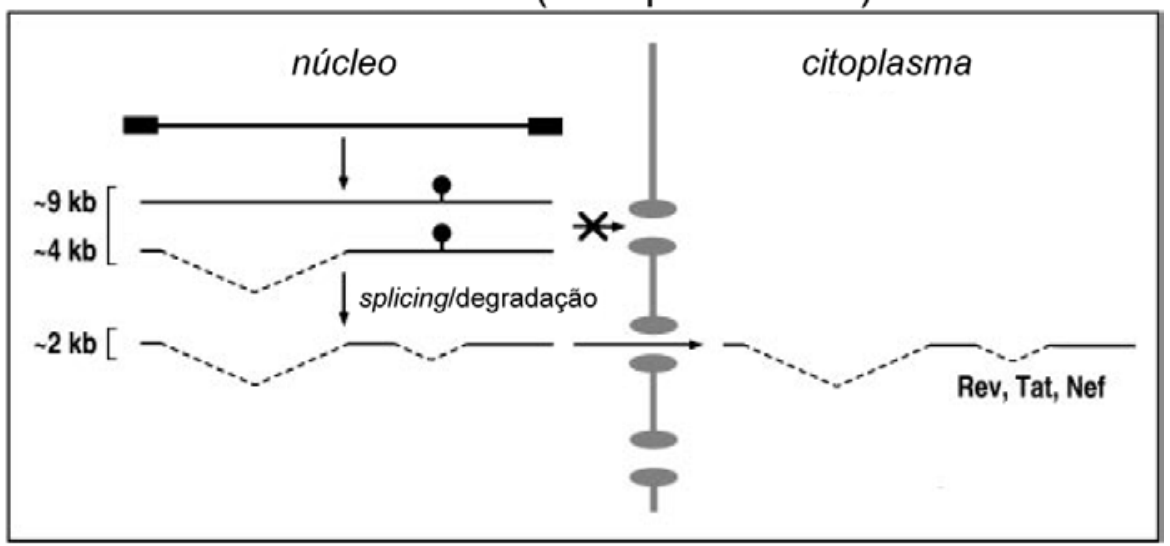

Fase Final (muito Rev)

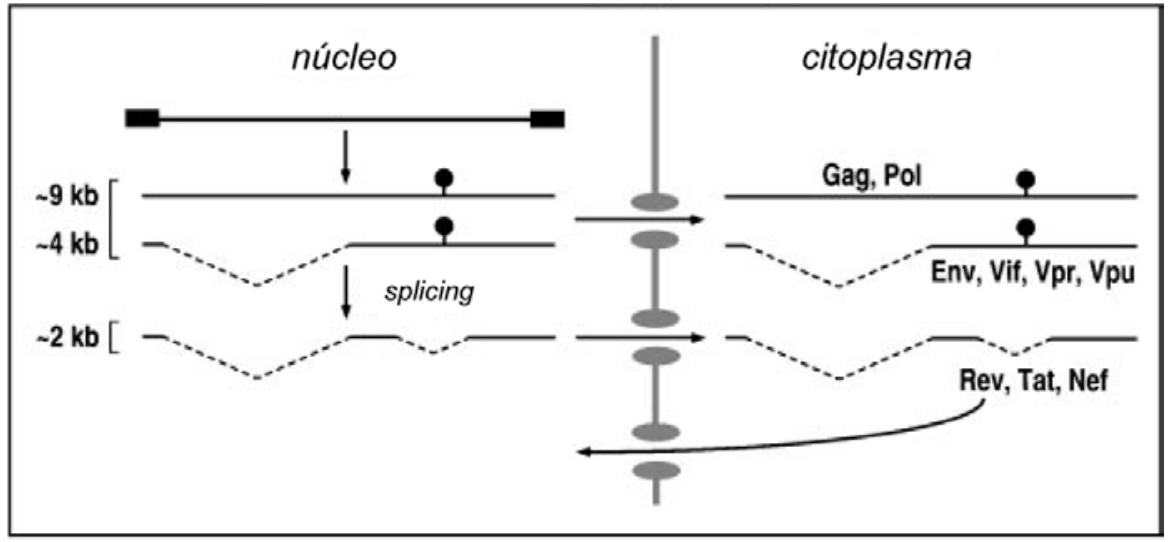

Inicialmente, apenas genes regulatórios são transcritos e exportados. Com o acúmulo de Rev no RNA nascente, mensageiros maiores contendo genes para proteínas estruturais são exportados e expressos.

Fonte: Modificado de Polland e Malim (1998). Com permissão.

O grande transcrito processado de $4 \mathrm{~kb}$ codifica as proteínas Env, Vif, Vpr e $\mathrm{Vpu}$, enquanto o transcrito não processado de $9 \mathrm{~kb}$ codifica também Gag e Pol (Seelamgari et al., 2004). As 15 proteínas que o HIV codifica são expressas a partir de 9 janelas de leitura, permanecem ligadas e dependem de processamento posterior para formarem as unidades ativas (Frankel e Young, 1998). Gag precisa ser clivada em MA, CA, NC e p6, enquanto Pol precisa ser processada em protease (PR), transcriptase reversa e integrase, pela ação da protease. Env também precisa ser processada, e é expressa, glicosilada e clivada em gp120, gp41 e peptídeo sinal (SP, signal peptide) no retículo endoplasmático, promovida pela sinalização do SP (Li et al., 2000b), para ser transportada para a porção externa da membrana celular.

A estrutura secundária do RNAm codante para as junções entre estes domínios (MA-CA-NC-p6, PR-RT-IN e SP-gp120-gp41) é altamente estruturada, formando 
grampos que podem retardar a tradução pelo ribossomo e permitir o tempo necessário para o dobramento proteico (Watts et al., 2009). O mesmo tipo de dobramento secundário do RNAm viral, desta vez formada por três hélices, parece prover a estrutura para que ocorra a mudança de fase de leitura (Watts et al., 2009) necessária para a expressão de pol ao fim de gag (Wilson et al., 1988).

\subsubsection{Montagem, brotamento e as proteínas derivadas de Gag}

A principal proteína responsável pelo brotamento e formação do capsídeo do HIV é Gag, capaz de formar partículas in vitro mesmo na ausência dos outros componentes virais (Campbell e Rein, 1999) (Figura 5). A poliproteína expressa tem em sua extremidade $\mathrm{N}$-terminal a subunidade MA, com seu topo globular miristilado com preferência por fosfolipídios ácidos, especialmente $\mathrm{PI}(4,5) \mathrm{P}_{2}$ (Saad et al., 2006), o que explica seu direcionamento para a porção inferior da membrana da célula (J ouvenet et al., 2006). A subunidade CA forma os oligômeros que aproximam Gag sob a membrana e ditam o formato da partícula brotando, enquanto NC traz os dímeros de RNAg que serão incorporados (Ganser-Pornillos et al., 2008), embora outros RNAs possam ser incorporados (Lu et al., 2011). A dimerização do RNAg e seu reconhecimento por Gag se dá pela região $\psi$ da LTR, e a complementaridade da sequência dita a chance de empacotamento entre genomas distintos, inclusive de subtipos discordantes (Onafuwa-Nuga e Telesnitsky, 2009). A subunidade p6 da extremidade C-terminal recruta a proteína celular ESCRT (Bieniasz, 2006). ESCRT e suas proteínas associadas são necessárias para formar e cortar o anel lipídico entre o envelope viral e a membrana celular, liberando a partícula formada (Bieniasz, 2009). O processo de brotamento leva cerca de 5 minutos (J ouvenet et al., 2008), e cada partícula possui cerca de 5000 cópias de Gag (Briggs et al., 2004), formando a matriz esférica sob a membrana celular carregada. 
Figura 5 - Representação esquemática de Gag e micrografias por crioeletroscopia da partícula de HIV-1 em maturação.

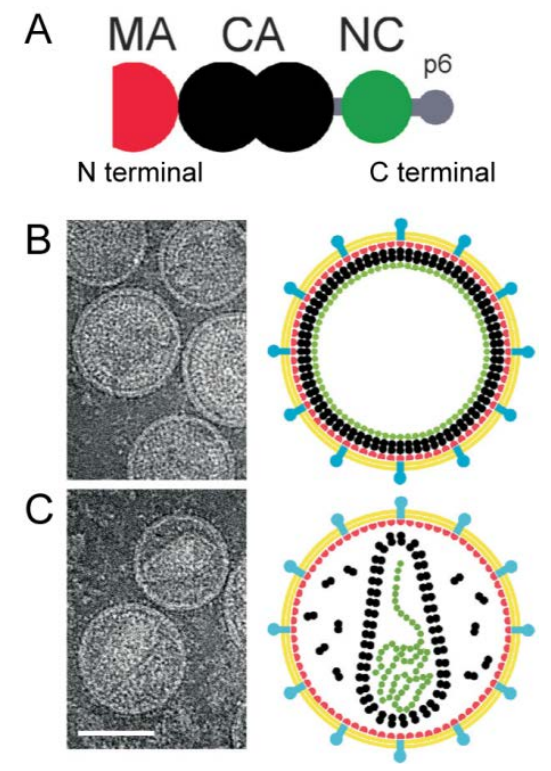

A - proteína Gag e suas porções de matriz (MA, em vermelho), capsídeo (CA, em preto), nucleocapsídeo (NC, em verde) e p6 (cinza). B - vírion imaturo com as proteínas de membrana em azul e a bicamada lipídica em amarelo. C - partícula madura pela ação da protease, com o capsídeo formado e NC ligada ao genoma viral. A barra de escala representa $100 \mathrm{~nm}$.

FONTE: Modificado de Briggs et al. (2004). Com permissão.

Após o brotamento, Gag e Gag-Pol são clivadas pela protease viral no processo de maturação, necessário para que as partículas sejam infecciosas. A protease do HIV-1 é uma aspartil-protease necessária para a clivagem da poliproteína precursora Gag-Pol, necessária para a maturação da partícula viral (Vogt, 1996) através do reconhecimento dos sítios p17-p24(CA), p24-p2, p2-p7(NC), p7-p1 e p1-p6 (Pettit et al., 1998). A protease é liberada de Pol por autocatálise, liberando RT e IN no processo. Em seguida é liberada a subunidade NC, que forma o complexo NC/ RNA estabilizando o genoma viral, seguida da clivagem de CA (Pettit et al., 1998), que multimeriza e forma o capsídeo. Etapa explorada por inibidores que competem com o substrato pelo sítio ativo da enzima e geram partículas imaturas e inviáveis (Ashorn et al., 1990). Sua especificidade, com propriedades como o reconhecimento de ligações Tyr-Pro e Phe-Pro, que não ocorre em peptidases de mamíferos (Wlodawer e Vondrasek, 1998), e o papel fundamental no ciclo viral fizeram dela um dos primeiros alvos de sucesso no desenvolvimento de medicamentos antirretrovirais.

Outra etapa da imunidade inata celular foi descoberta através da investigação de células não permissivas ao vírus com a deleção do gene vpu (Terwilliger et al., 1989), que mantinham as partículas formadas em sua membrana, liberadas pela clivagem 
com proteases (Neil et al., 2006). A responsável pela ação é a colerina (Neil et al., 2008; Van Damme et al., 2008), uma proteína extracelular com suas extremidades N e C-terminal inseridas na membrana, que funciona como uma âncora capaz de prender o envelope viral da partícula formada à membrana celular (Perez-Caballero et al., 2009), mecanismo inespecífico que atua em diversos vírus envelopados como os Filovírus (Kaletsky et al., 2009). Vpu (viral protein u) é uma pequena proteína com um domínio $\mathrm{N}$-terminal transmembrânico e uma cauda citoplasmática (Terwilliger et al., 1989), que impede o direcionamento da colerina à membrana e promove sua degradação pelo proteossomo (Goffinet et al., 2009), bem como a degradação do receptor CD4 (Magadan et al., 2010). A exemplo das outras proteínas celulares de resposta antiviral, a colerina registra grandes valores de seleção positiva, e a deleção da região reconhecida pela proteína viral Nef de SIV, como ocorre em outros primatas, atesta para a competição evolutiva entre patógeno e hospedeiro (Meyerson e Sawyer, 2011).

\subsection{A protease}

Descoberta em 1988 (Seelmeier et al., 1988), embora proteases retrovirais já fossem conhecidas (Crawford e Goff, 1985), a protease do HIV-1 é um homodímero constituído de dois monômeros de 99 aminoácidos (Figura 6). Classificada como aspartil-protease, possui em seu sítio ativo uma tríade catalítica formada pelos aminoácidos aspartato 25, treonina 26 e glicina 27. É a única aspartil-protease com um sítio ativo formado por duas subunidades. Possui grande flexibilidade, e parte de suas interações, tanto com o substrato quanto com si mesma, são mediadas por moléculas de água. Sua estrutura é composta por nove folhas $\beta$ : $\beta$ a aminoácidos 1 a 4 ; ßb aminoácidos 9 a 15; $\beta c$ aminoácidos 16 a 27, região que termina na tríade catalítica; $\beta \mathrm{d}$ aminoácidos 30 a 35; $\beta \mathrm{a}$ aminoácidos 43 a 49; $\beta \mathrm{b}$ ' aminoácidos 52 a 66, esta folha beta forma, junto ao loop anterior o flap da protease; $\beta c^{\prime}$ aminoácidos 69 a 78; $\beta \mathrm{d}^{\prime}$ aminoácidos 83 a 85; e a região $\beta$ C-terminal responsável pela dimerização da enzima (Wlodawer e Erickson, 1993). Seu sítio ativo possui um centro altamente hidrofóbico (subsítios S1 e S1', Figura 7) e sete subsítios capazes de reconhecer as regiões P3 a P4' do substrato (Prabu-J eyabalan et al., 2000, 2002). 
Figura 6 - Protease do HIV-1.

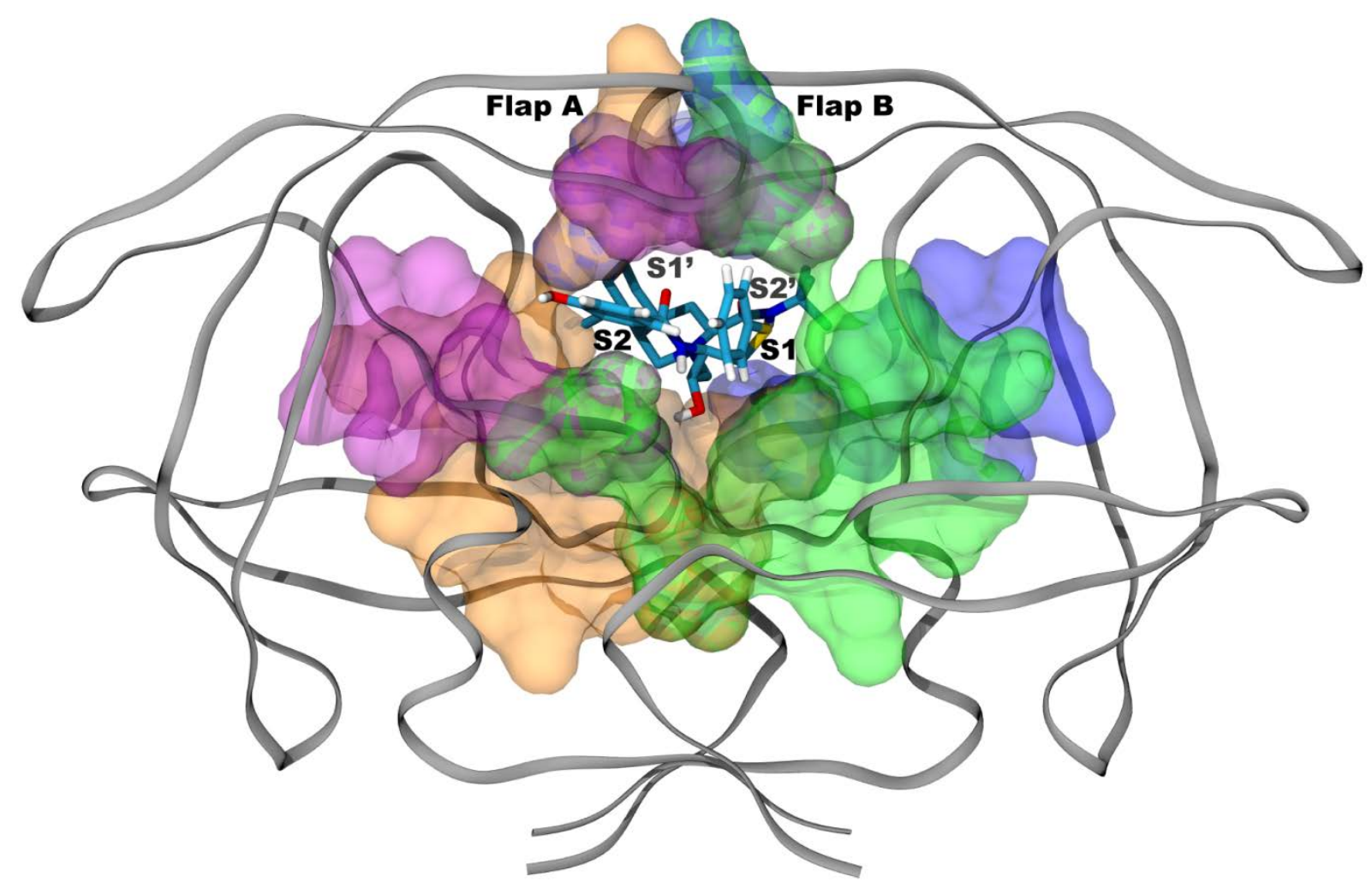

A protease é composta por duas cadeias idênticas de 99 aminoácidos (Cadeia A à esquerda). Os subsítios de ligacão ao substrato, neste caso o inibidor nelfinavir, S1 (em verde), S2 (em roxo), S1' (em laranja) e S2' (em azul) aparecem em destaque.

Fonte: Iamarino (2012).

Figura 7 - Protease em vista superior.

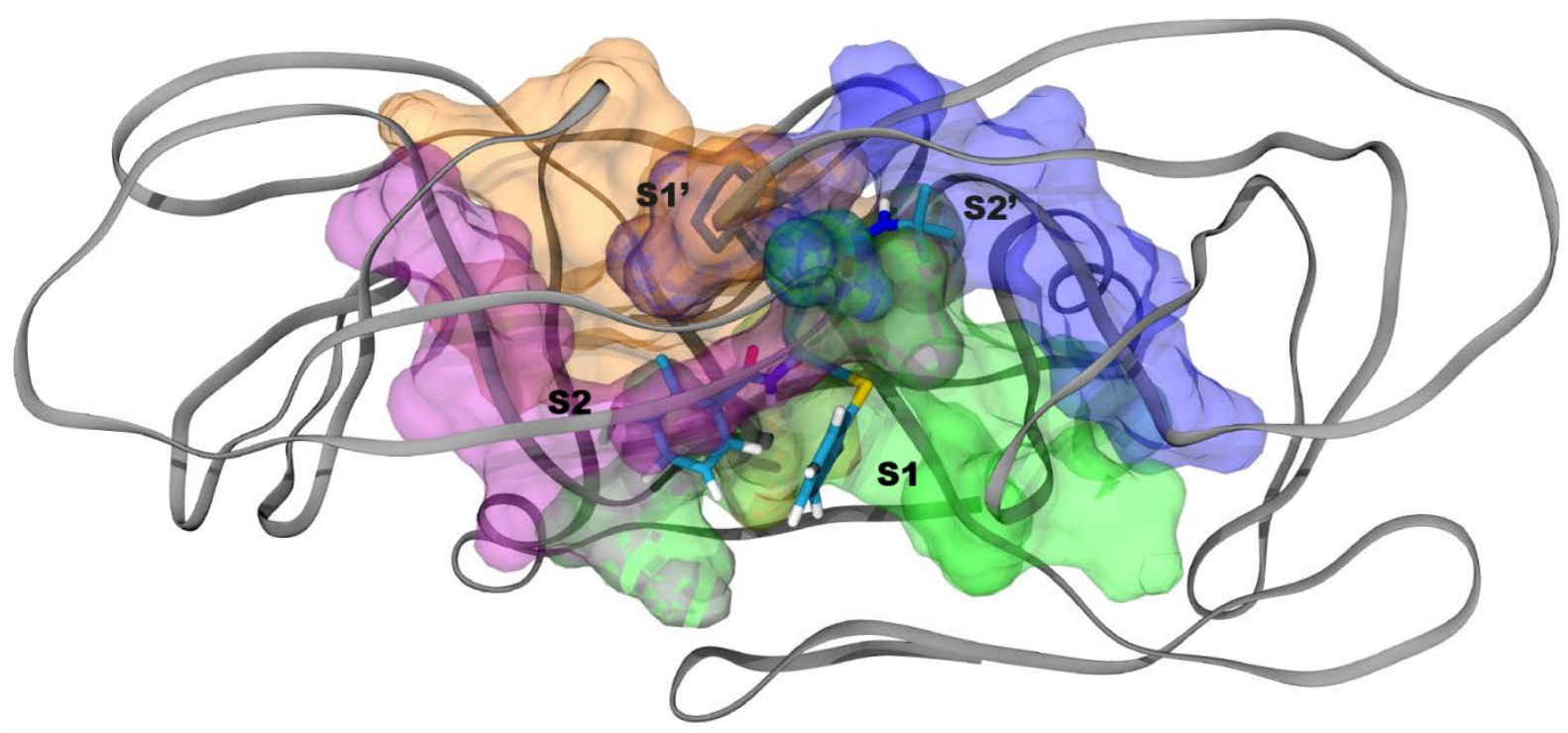

Vista superior da protease ligada ao nelfinavir destacando os subsítios S1 (em verde), S2 (em roxo), S1' (em laranja) e S2' (em azul).

Fonte: Iamarino (2012). 
A ligação com o substrato se dá pela região dos flaps (Scott e Schiffer, 2000) (Figura 6), grampos beta formados pelas duas cadeias que envolvem uma cavidade catalítica bastante hidrofóbica. Eles estão abertos na enzima livre (Wlodawer et al., 1989) e se fecham quando ela está ligada a um substrato (Fitzgerald et al., 1990), e também sob ação de inibidores (Heal et al., 2012). Simulações in silico demonstraram grande flexibilidade e um movimento de abertura de até $25 \AA$ (Collins et al., 1995), que permitiria a entrada das grandes proteínas que servem como substrato (Hornak et al., 2006). Esta flutuação dos flaps ocorre em dois períodos, dos nanossegundos e dos milissegundos, e já foi captada através da resolução estrutural através de ressonância magnética nuclear (Freedberg et al., 2002; Katoh et al., 2003). Sua atividade autocatalítica está relacionada com a maturação do vírus após o brotamento, clivando a poliproteína Pol e a poliproteína Gag (Seibold e Cukier, 2007).

O mecanismo de clivagem se dá pela ação dos resíduos de asparagina catalíticos, uma das quais precisa estar protonada (Pearl e Blundell, 1984), a Asp25 segundo o modelo corrente de catálise (Davies, 1990) (Figura 8). O estado de protonação dos resíduos Asp25 e Asp25' foi alvo de intensa investigação durante mais de duas décadas (Pearl e Blundell, 1984; Piana et al., 2001; Wittayanarakul et al., 2008), uma vez que a cristalografia de raios $\mathrm{X}$ não permite a inferência do estado de protonação. Apenas técnicas mais recentes de cristalografia de nêutrons e raios $\mathrm{X}$ apontam para a protonação da Asp25 (Adachi et al., 2009). 
Figura 8 - O modelo mais aceito para o mecanismo de catálise da protease do HIV incorporando a mudança de conformação dos flaps e a estrutura assimétrica da protease.

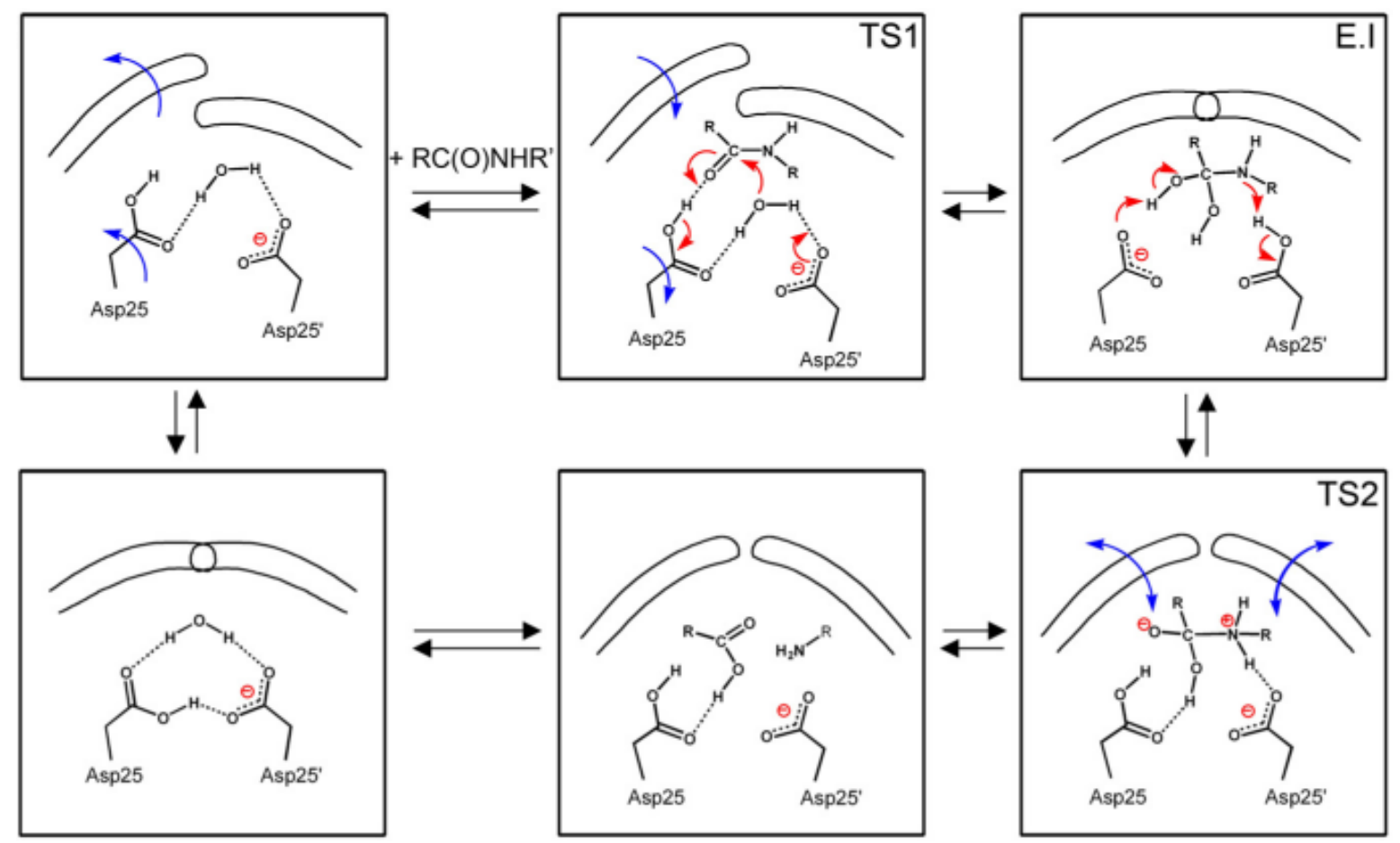

O resíduo desprotonado Asp25' age como uma base e remove um próton da molécula de água 301 (Miller et al., 1989) enquanto o ácido aspártico protonado Asp25 doa um próton ao oxigênio carbonil da ligação peptídica durante o primeiro estado de transição (TS1), formando o complexo enzimático com o intermediário tetraédrico (EI). No segundo estado de transição (TS2), a ligação peptídica é quebrada e o flap se abre novamente, liberando a amina e o ácido carboxílico, e admitindo a entrada de uma nova molécula de água. Fonte: Modificado de Torbeev et al. (2011). Com permissão.

O papel dos flaps no mecanismo de catálise foi reavaliado através da troca dos resíduos desta região por análogos que alteraram sua flexibilidade (Torbeev et al., 2011), mostrando que o movimento de abertura e fechamento serve não apenas para o correto posicionamento do substrato sobre a molécula de água nucleofílica (Torbeev et al., 2009), mas também para a mudança conformacional do resíduo Asp25 necessário para a catálise. Em seguida, o aspartato desprotonado Asp-25’ atua como base e remove um próton da molécula de água nucleofílica, enquanto o ácido aspártico protonado doa um próton para o oxigênio carbonila da ligação peptídica (Figura 8). 


\subsection{A terapia e inibidores de protease}

Devido à grande demanda pela terapia para pacientes que não tinham alternativas além do tratamento paliativo de infecções oportunistas à medida que a imunodeficiência se instalava, a busca por antirretrovirais eficazes contra o HIV foi bastante intensa. Por se tratar de uma enzima sem função essencial em eucariotos, a transcriptase reversa se revelou um alvo especialmente interessante, respeitando o princípio terapêutico de atacar um alvo específico do patógeno e minimizar os efeitos colaterais do tratamento (Cohen, 1977).

O terminador de cadeia zidovudina ou AZT, sintetizado durante a década de 1960 e inicialmente desenhado para elucidar o mecanismo da replicação do DNA (Kornberg, 1982), foi depois usado como uma droga antitumoral, mas abandonada pela baixa eficiência em camundongos. O AZT é um análogo de nucleosídeo, que compete com o nucleotídeo timina pela incorporação no DNA nascente mas possui um grupo 3'azida que impede a ligação fosfodiéster, pois não propicia ataque nucelofílico do fostato 5’ do próximo nucleotídeo `a hidroxila 3’ do último nucloetídio incorporado . O AZT se revelou capaz de conter a replicação de retrovírus ainda em 1974 (Ostertag et al., 1974), o que a tornava um candidato muito promissor. Testado contra o HIV em 1985 (Mitsuya et al., 1985), o AZT foi o primeiro fármaco antirretroviral disponibilizado para pacientes, em 1987, mas em poucos meses se viu que o vírus deixava de responder ao tratamento e variantes resistentes eram selecionadas (Fischl et al., 1987). Em pouco tempo, outros análogos de nucleosídeos terminadores de cadeia foram desenvolvidos e adotados como agentes antirretrovirais, entre eles didanosine e zalcitabine (Mitsuya e Broder, 1986), e logo em seguida o stavudine (Martin et al., 2010b).

Com o teste de substratos baseados nos sítios de clivagem de Gag, foi possível determinar a especificidade de cada região do sítio ativo da protease do HIV-1 cristalizada pouco tempo antes (McKeever et al., 1989), e com isso resolver sua estrutura tridimensional quando ligada ao substrato (Miller et al., 1989; Navia et al., 1989). De posse da estrutura e da afinidade do sítio ativo da protease, iniciou-se uma busca ativa por inibidores específicos desenhados para ela (Roberts et al., 1990). Pela primeira vez se fez o desenvolvimento inteligente de antivirais: ao invés de uma busca por um composto ativo entre vários candidatos, como foi o caso do AZT, os inibidores de protease (PIs) foram construídos intencionalmente para serem reconhecidos com 
grande afinidade pela protease do HIV-1, com a ligação peptídica clivada pela tríade catalítica substituída por um grupo hidroxietileno que não pode ser clivado (Kuntz, 1992) (Figura 9).

Figura 9 - Ligação peptídica substituída
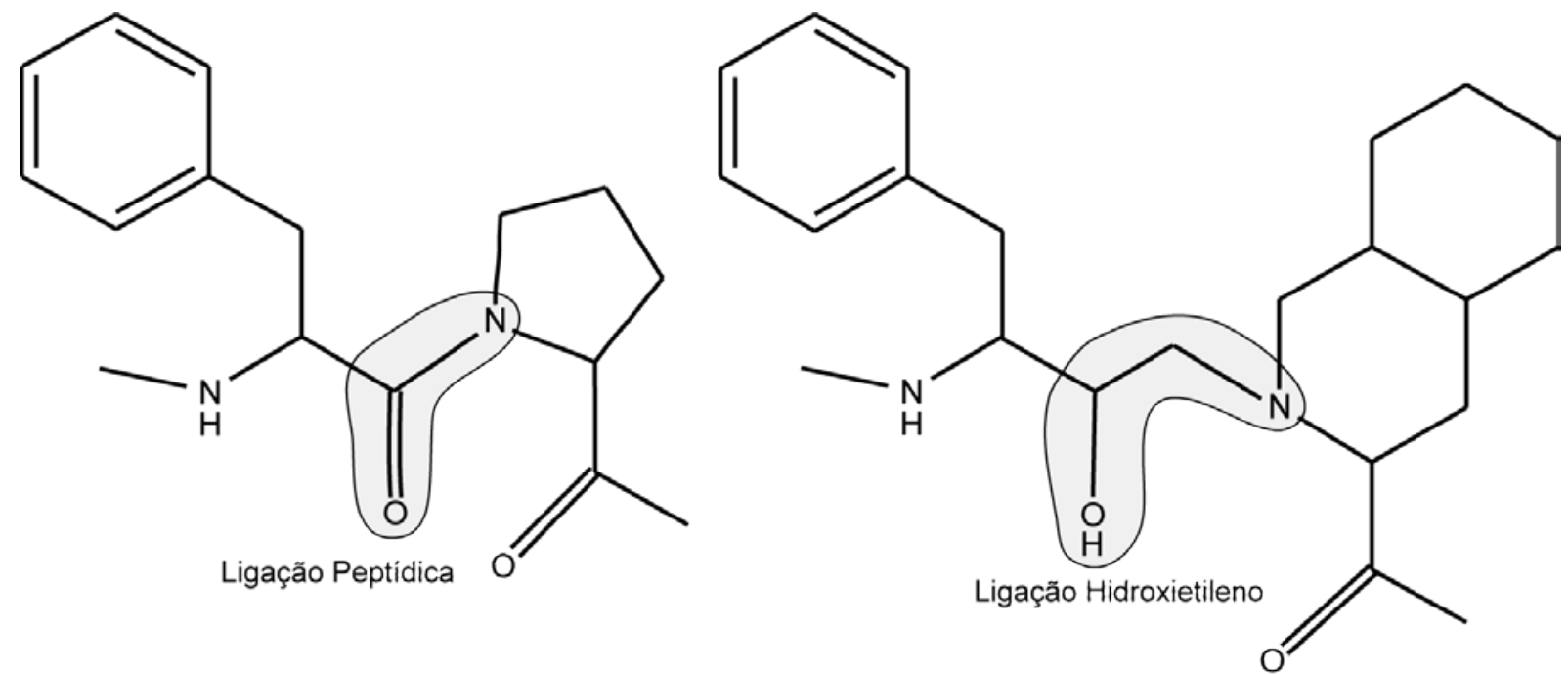

Representação da ligação peptídica do substrato à esquerda, mimetizada e modificada pelo hidroxietilieno não hidrolisável em quase todos inibidores de protease.

Fonte: Iamarino (2012).

Assim, o primeiro inibidor de protease foi lançado em 1995, ainda baseado na capacidade de clivagem de endopeptidases de mamíferos (Wlodawer e Vondrasek, 1998), o saquinavir (Roberts et al., 1990; Craig et al., 1991). Enquanto a protease é capaz de reconhecer até sete resíduos do substrato, através dos subsítios S3 a S4' (Prabu-J eyabalan et al., 2000, 2002), os inibidores mimetizam peptídeos menores, e normalmente compreendem apenas a região entre S2 e S2' (Figura 7 e Figura 10) (Wlodawer e Vondrasek, 1998).

Apesar da nova classe de antivirais, já se esperava que mutações de resistência ocorressem, e já haviam sido observadas para PIs (Condra et al., 1995). Desenvolvido antes das primeiras estruturas de protease serem resolvidas, o saquinavir foi substituído por outros antirretrovirais, os inibidores de segunda geração, também devido à sua baixa biodisponibilidade por via oral e rápido surgimento de mutações de resistência. Para tanto, centenas de cristais da protease tiveram suas estruturas resolvidas, com diversas mutações de resistência, em diferentes condições, e complexadas com muitos inibidores (Erickson e Burt, 1996).

Os inibidores de primeira geração, como o saquinavir e o indinavir, foram desenhados para ter uma alta afinidade pelo sítio ativo da protease através da 
maximização de interações hidrofóbicas com os subsítios S1 e S1'. Para isso, foram desenhados com largos grupos apolares nas regiões P1 e P1' (Figura 10), enquanto fazem poucas interações polares (Wlodawer e Vondrasek, 1998). Devido a estas propriedades, a maioria das mutações de resistência primária a estes inibidores ocorrem em resíduos localizados no sítio ativo, como D30, G48, I50, V82 e I84, ou em resíduos com influência indireta no sítio ativo, como M46 e L90 (Shafer e Schapiro, 2008). O mais comum são mudanças por aminoácidos com cadeias laterais que mantém a mesma polaridade, mas são maiores ou menores, interferindo na geometria do sítio ativo (Sanches et al., 2007b).

Já os PIs de segunda geração tiveram seu desenvolvimento baseado em informações estruturais, e se baseiam menos em interações hidrofóbicas e mais em interações, polares. As regiões P1 e P1' são menores e acomodam uma maior mudança do sítio ativo (Martinez-Cajas e Wainberg, 2007), enquanto vários átomos polares foram acrescentados para mimetizar intermediários da catálise e fazer interações com átomos polares do esqueleto proteico, que não podem ser evitadas com mutações (Ghosh et al., 2006).

Figura 10 - Estrutura do inibidor nelfinavir

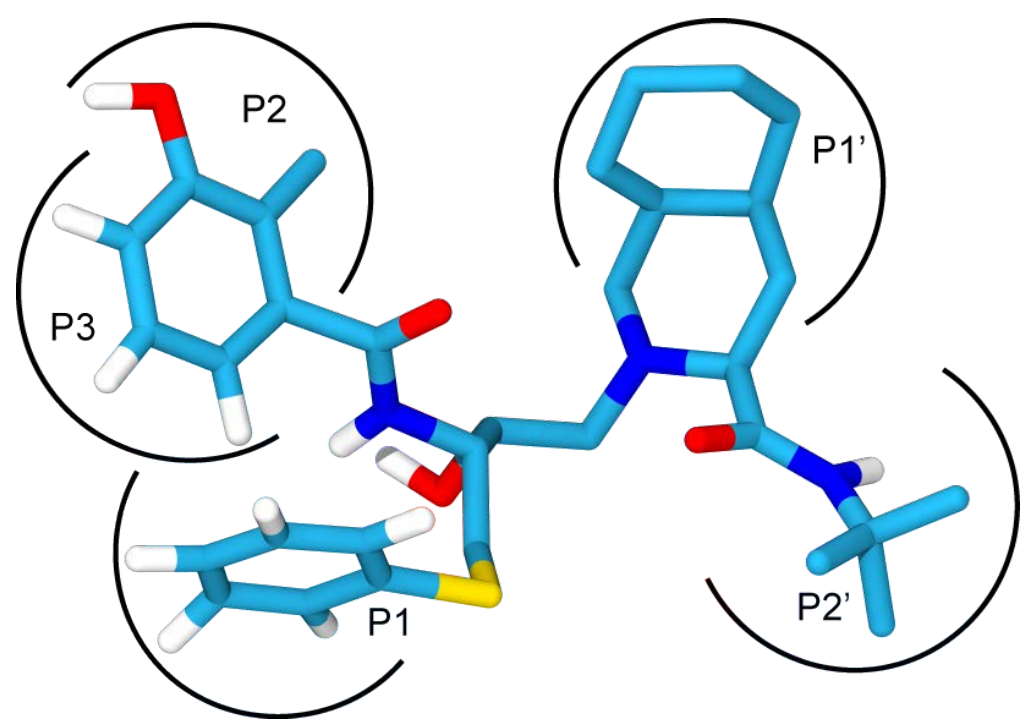

Estrutura tridimensional do inibidor destacando as regiões P1, P2, P1' e P2', que interagem com os respectivos subsítios da protease do HIV-1. Átomos de carbono estão coloridos em azul claro, átomos de nitrogênio em azul escuro, oxigênio em vermelho, enxofre em amarelo e hidrogênio em branco.

Fonte: Iamarino (2012).

O nelfinavir (Figura 10) foi o quarto inibidor de protease a ser lançado (Wlodawer e Vondrasek, 1998), em 1997 (Kaldor et al., 1997). No período, foi o PI 
com maior eficácia (Easterbrook et al., 2001) e maior aderência pelos pacientes (Ledergerber et al., 1999), possivelmente por apresentar menos efeitos adversos (Pai e Nahata, 1999). No Brasil, foi adotado em 1998 e se tornou um dos principais inibidores de protease utilizados, até ser substituído em torno de 2004 por inibidores desenvolvidos posteriormente (Nunn et al., 2007), como o lopinavir/r e o atazanavir.

Prolongar o período efetivo da terapia, antes do surgimento de mutações de resistência, foi possível após a adoção da estratégia de terapia antirretroviral altamente ativa (HAART - High Active Antiretroviral Therapy), proposta em 1996 (Ho, 1995), capaz de manter o vírus sob controle e prolongar a vida do paciente por anos com o uso simultâneo de duas ou mais classes de antirretrovirais. Graças à HAART, o número de mortes relacionadas à AIDS tem declinado desde 2004 (UNAIDS/WHO, 2010), o que implica em um número crescente de pacientes que dependem da eficácia da terapia para sobrevivência.

No Brasil, o AZT passou a ser distribuído gratuitamente em 1991, e a HAART foi adotada como tratamento garantido em 1996 (Marins et al., 2003), cobrindo 100\% dos pacientes (Chequer et al., 2002). Após esta medida, o número de mortes causadas por AIDS declinou sensivelmente (Teixeira et al., 2004) e, atualmente, mais de 190 mil pacientes estão sob terapia (Ministério da Saúde do Brasil, 2011). Situação similar ocorreu na Argentina, que adotou a HAART ao final de 1996, o que causou um declínio no número de novos casos (Boletín ..., 2002).

\subsection{Outros alvos terapêuticos}

Existem diversas etapas da replicação do HIV-1 que podem ser alvo de terapia, não apenas a maturação promovida pela protease (Figura 11). Dentro do ciclo do HIV, os inibidores que atuam na fase mais precoce são os inibidores de ligação e fusão. A entrada do HIV na célula alvo CD4+ depende da ligação da proteína gp120 com o receptor CD4 e a um dos co-receptores, para em seguida ocorrer a fusão do envelope viral à membrana celular, promovida pela proteína gp41 (Westby e van der Ryst, 2005). Por atuarem na parte exterior da célula, inibidores de fusão atingem alvos potencialmente mais acessíveis e não dependem do processamento celular para se tornarem metabolicamente ativos. 
Figura 11 - Ciclo replicativo do HIV-1 e alvos terapêuticos

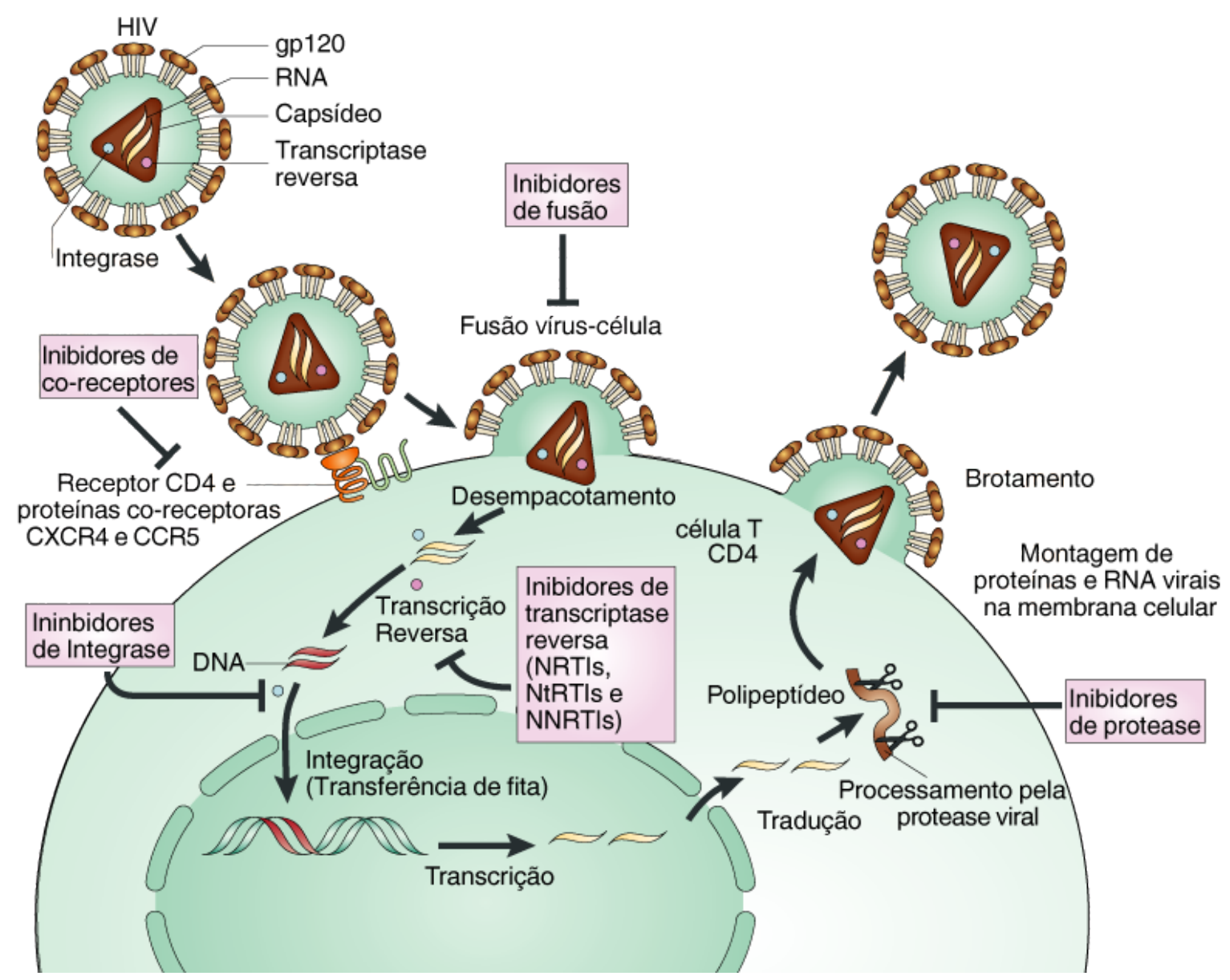

Alvos de terapias antirretrovirais em uso corrente estão em destaque.

Fonte: Modificado de De Clercq (2007). Com permissão.

O primeiro antirretroviral a bloquear este processo foi o inibidor de fusão enfuvirtide, um peptídeo injetável de 36 aminoácidos análogo ao peptídeo de fusão conservado na proteína gp41, que impede sua mudança conformacional e a fusão de membranas (Matthews et al., 2004). A ligação ao co-receptor também pode ser atacada, e a deleção natural de uma porção do gene CCR5 $(\Delta 32)$ capaz de prover resistência ao HIV CCR5-trópico (Liu et al., 1996) inspirou o posterior desenvolvimento do maraviroc (Westby e van der Ryst, 2005), um inibidor bastante seletivo de CCR5 capaz de se ligar à gp120 (Dorr et al., 2005).

A classe mais diversa e numerosa de antirretrovirais são os inibidores da replicação genômica, todos possuem ação sobre a polimerase de DNA dependente de RNA. Os inibidores da transcriptase reversa podem ser divididos em inibidores nucleosídicos (NRTIs, nucleoside reverse trancriptase inhibitors) e inibidores não nucleosídicos (NNRTIs, non-nucleoside reverse trancriptase inhibitors). Os NNRTIs (efavirenz, nevirapine, delavirdine, etravirine e o mais recente rilpivirine) se ligam a 
um bolso hidrofóbico formado próximo ao sítio ativo da transcriptase reversa (Kohlstaedt et al., 1992), e com isso causam mudanças conformacionais na enzima que impedem a síntese do DNA (Esnouf et al., 1995) e a ação da RNase H (Hang et al., 2007).

Como explicado acima para o AZT, os NRTIs são moléculas que atuam como terminadoras de cadeia, pois impedem a replicação por não possuírem o grupo 3’hidroxila da ribose (ou pseudo-ribose) que faz a ligação fosfodiéster, impedindo portanto o ataque nucleofílico do fosfato $5^{\prime}$ do nucleotídeo a ser adicionado à hidroxila 3', e consequentemente a extensão da cadeia nascente, e se aproveitam do fato de que a trancriptase reversa, assim como as RNA polimerases RNA dependentes, não é capaz de reparar bases erroneamente incorporadas (VivetBoudou et al., 2006). São análogos de nucleosídeos que competem com os dNTPs celulares e são reconhecidos pelas quinases celulares, e requerem três passos de fosforilação celular para serem convertidos nos metabólitos ativos (i.e., nucleotídeos). Sete inibidores desta classe foram aprovados até o momento, zidovudina, didanosine, zalcitabine, stavudine, lamivudine, abacavir e emtricitabine. Inibidores de transcriptase análogos de nucleotídeos, NtRTIs, já possuem um grupo fosforilado e requerem apenas dois passos para serem ativados. Apenas um NtRTI foi aprovado para uso médico até o momento, o tenofovir.

Além da transcrição reversa, outro alvo durante a replicação do genoma do HIV é a integração de seu DNA no genoma da célula hospedeira, através dos inibidores da integrase (INIs). Os inibidores raltegravir e elvitegravir (este ainda em testes) são capazes de se ligar aos dois íons $\mathrm{Mg}^{2+}$ do sítio ativo e interromper a transferência de nucleotídeos entre o complexo de integração e o cromossomo (Hare et al., 2010), impedindo a formação do provírus. Seu uso é direcionado para a combinação com outros antirretrovirais no resgate terapêuticos de pacientes com vírus multirresistentes (Croxtall e Keam, 2009).

\subsection{As mutações de resistência}

Pouco tempo após a distribuição do AZT, em menos de seis meses de tratamento em alguns casos, a terapia com este antirretroviral começou a dar sinais de falha, com o surgimento de linhagens completamente resistentes ao tratamento (Fischl et al., 1987). Logo a causa deste fenômeno foi reconhecida. O surgimento 
precoce de linhagens resistentes se deve à sua rápida taxa de evolução, causada por vários fatores: uma grande população viral em um único paciente, com cerca de $10^{10}$ partículas produzidas por dia (Ho et al., 1989; Perelson et al., 1996); a alta incorporação de erros de sua transcriptase reversa que, por não possuir atividade reparadora, incorpora cerca de um nucleotídeo errado por ciclo de replicação (Preston et al., 1988; Mansky e Temin, 1995); o tempo curto de geração viral de 1 a 2 dias (Ho et al., 1995; Wei et al., 1995); e sua alta taxa de recombinação, com cerca de 2 a 3 eventos por ciclo replicativo, que favorece a combinação de mutações de resistência favoráveis (Zhuang et al., 2002).

Mutações que conferem resistência direta a drogas frequentemente têm um efeito negativo no fitness viral por interferirem na atividade da enzima alvo (Coffin, 1995) de maneira que, para que uma mutação de resistência seja fixada, ela precisa ser acompanhada de mutações secundárias, que não necessariamente conferem diretamente resistência, mas compensam as perdas causadas pela mutação primária. Estas mutações não precisam ocorrer em ordem temporal, primárias seguidas de secundárias, e algumas mutações secundárias são polimorfismos naturais que já estão presentes na população antes mesmo do tratamento. Assim, existem vários mecanismos de escape à droga que podem ocorrer, e podem ou não estar relacionados com o subtipo viral (Shafer, 2002).

Mesmo sob intensa terapia, a variação genética contínua do HIV (Frenkel et al., 2003) e o surgimento de variantes resistentes sugerem uma replicação residual (Grossman et al., 1999), em baixos níveis mas presentes, conforme demonstrada pela formação de epissomos não integrados em pacientes sob HAART tratados com o inibidor de integrase raltegravir (Buzon et al., 2010). Esta replicação pode ocorrer em compartimentos onde a concentração de inibidores não atinge valores necessários (Pierson et al., 2000), ou em regiões onde a transmissão célula a célula e a concentração de partículas derivadas das múltiplas infecções permite a perda de sensibilidade ao inibidor, independente de mutações de resistência (Sigal et al., 2011).

\subsubsection{Mutações de resistência a inibidores de transcriptase reversa eintegrase}

As mutações de resistência a NRTIs podem causar resistência de três maneiras principais: (i) as NAMs ou nucleoside-associated mutations diminuem a susceptibilidade para quase todos os NRTIs, menos 3TC, aumentando a remoção dos 
análogos (pirofosforólise) incorporados na cadeia de DNA em formação e liberando a extensão (Meyer et al., 1998; Meyer et al., 1999), (ii) as mutações $184 \mathrm{~V}$ e $74 \mathrm{~V}$ modificam a conformação da RT de maneira que análogos como 3TC e ddI deixam de ser incorporados (Loveday, 2001), aumentando a fidelidade da transcriptase reversa e diminuindo sua processividade (Nikolenko et al., 2004) e, (iii) mutações que não necessariamente ocorrem na RT, mas aumentam a incorporação de moléculas de RT por virion (Peters et al., 2001; Soriano e Mendoza, 2002).

Como todos NNRTIs têm um mecanismo de ação parecido e agem no bolso hidrofóbico próximo ao sítio ativo da transcriptase reversa, causando uma inibição alostérica por deslocamento do sítio ativo (Kohlstaedt et al., 1992; Huang et al., 1998), mutações que conferem resistência se localizam quase todas nessa região, nos códons de 98 a 108, 179 a 190 e 225 a 236 (Shafer et al., 2000). Mutações de resistência emergem rapidamente, sugerindo que sejam pré-existentes na população de vírus não exposta à droga (Havlir et al., 1996). O grupo O do HIV-1 e o HIV-2 são intrinsecamente resistentes à maioria dos NNRTIs (Larder et al., 1989), já o grupo M do HIV-1 tende a ter maior variabilidade em relação à resistência a NNRTIs do que NRTIs e PIs (Brown et al., 2000).

Os inibidores de integrase, por serem mais recentes, ainda possuem poucas mutações de resistência primária e acessórias conhecidas, e suas possíveis consequências ainda são pouco claras (Ceccherini-Silberstein et al., 2010). São conhecidos três caminhos de resistência a raltegravir dependentes de duas ou mais mutações, que dependem das mutações primárias Y143R, Q148H/K/R e N155H, todas muito raramente encontradas em pacientes não tratados (CeccheriniSilberstein et al., 2009).

\subsubsection{Mutações de resistência em protease e Gag}

Na protease do HIV, mutações primárias geralmente ocorrem no entorno do sítio ativo podendo mudar polaridade, flexibilidade e o formato do sítio ativo. O mais comum são mudanças por aminoácidos com cadeias laterais que mantém a mesma polaridade, mas são maiores ou menores, interferindo na geometria do sítio ativo (Sanches et al., 2007b). Tais mudanças implicam em uma menor afinidade pelo inibidor e pelo substrato. Já foram catalogados quase 30 resíduos capazes de sofrer mais de 50 mutações associadas à resistência na protease (Shafer e Schapiro, 2008). 
Os sítios diretamente envolvidos em resistência podem ocorrem em diferentes regiões: os aminoácidos 23, 30, 32, 47, 48, 50, 82 e 84 se situam no entorno do sítio de ligação do substrato; os aminoácidos 46 e 54 se situam no flap; e os aminoácidos 76, 66 e 90 se situam na região interna da protease (Shafer e Schapiro, 2008). Para restaurar a atividade enzimática, são necessárias mutações no entorno do sítio ativo e na região dos flaps. Como forma de compensar as mutações de resistência, a segunda geração de inibidores de protease foi desenhada com base na afinidade de proteases resistentes, buscando o resgate de terapia em pacientes que já não estavam sob alcance (Hou et al., 2008).

A resistência a nelfinavir geralmente pode ocorrer por diferentes padrões de mutações. No subtipo B a forma mais frequente se dá pela mutação D30N, que possui uma pequena barreira genética, uma mutação de guanina para adenina (Patick et al., 1998; Perrin e Mammano, 2003). A asparagina na posição 30 possui um grupo menos carregado na cadeia lateral e não tem a capacidade de manter pontes de hidrogênio com o substrato e mediadas por água no subsítio S2, ela é altamente específica do tratamento com nelfinavir e pode ser seguida da mutação restauradora N88D (Ode et al., 2005). O outro caminho de resistência ocorre pela mutação L90M. Embora o aminoácido 90 esteja fora do sítio ativo, ele se localiza logo abaixo do ácido aspártico 25, responsável pela formação dos intermediários de catálise na degradação do substrato. A cadeia lateral mais volumosa da metionina faz mais contatos com os aminoácidos 24 a 26, interferindo na flexibilidade do bolso S1/S1' e na interação do aminoácido Asp25 com o inibidor (Calazans et al., 2005). A mutação V82A introduz uma cadeia lateral menor que causa uma assimetria entre os subsítios S1 e S1' diminuindo as interações hidrofóbicas entre o aminoácido 82 e a região P1 do substrato. Está associada à resistência a nelfinavir na presença de outras mutações (Clemente et al., 2004a).

Embora diferentes subtipos apresentem as mesmas mutações que o subtipo B, o padrão em que as mutações ocorrem pode ser diferente (Kantor et al., 2005), principalmente na região da protease, como demonstrado por um trabalho realizado com base em 583 sequencias argentinas, dos subtipos B e BF (Carobene et al., 2004). Nenhum dos polimorfismos que diferenciam o subtipo F do subtipo B ocorre em resíduos envolvidos diretamente na interação com o substrato. Porém, são sítios frequentemente relacionados com mutações secundárias, de maneira que proteases $\mathrm{F}$ têm naturalmente aminoácidos que mantém a atividade catalítica apesar de mutações 
primárias ocorridas posteriormente (Sanches et al., 2007b). Como consequência todos PIs são menos eficazes contra elas (Krauchenco et al., 2009).

A mutação M36I, por exemplo, é considerada uma mutação acessória no subtipo B ocorrendo em $6 \%$ das suas proteases, mas é o aminoácido consenso em outros subtipos ocorrendo em 83\% das sequencias do não B do grupo M (Pieniazek et al., 2000), nas quais facilita a ocorrência de resistência a inibidores, embora possua $o$ efeito contrário para o subtipo B (Lisovsky et al., 2010). A mutação L90M, por outro lado, é comum no subtipo B sob tratamento com PIs, mas o mesmo não acontece em outros subtipos, para os quais a mutação L89M é facilmente encontrada. A baixa ocorrência de ambas as mutações $89 \mathrm{M}$ e $90 \mathrm{M}$ e a similaridade entre as estruturas sugere que ambas as mutações tenham o mesmo efeito, diminuindo o espaço disponível para o inibidor nos subsítios S1/S1' (Sanches et al., 2007b). A baixa atividade de proteases duplo mutantes e a grande frequência de proteases não B com o polimorfismo 89M atuam como uma barreira genética para o aparecimento de L90M (Calazans et al., 2005).

Além das mutações primárias e secundárias, a poliproteína Gag também exerce papel no desenvolvimento de resistência a antivirais. Com a presença de sítios de clivagem reconhecidos pela protease, várias mutações em Gagjá foram relacionadas a vírus resistentes a protease, tanto em sítios de clivagem como fora deles (Gatanaga et al., 2002; Tamiya et al., 2004). Tais mutações devem ajudar a compensar a mudança na atividade catalítica das proteases resistentes, uma vez que, como os inibidores mimetizam os peptídeos reconhecidos como substrato, mutações que reduzam afinidade da protease pelos antivirais também modificam sua especificidade. Isto é suportado pela constatação de que vírus resistentes possuem perfis diferentes de acumulação de poliproteínas parcialmente processadas (Dauber et al., 2002).

Desde 1977, simulações de dinâmica de proteínas têm permitido uma melhor compreensão do funcionamento das mesmas (McCammon et al., 1977). A protease do HIV-1, modelada e simulada pela primeira vez em 1992 (Harte et al., 1992), segue como um dos principais exemplos de sucesso do desenvolvimento inteligente de inibidores baseados em propriedades estruturais e de ligação. Para se entender o efeito estrutural das mutações na protease, e sua interação com os inibidores, diversas simulações in silico foram realizadas, demonstrando características, como o efeito de mutações de resistência na menor afinidade por inibidores (Piana et al., 2002; Chen et al., 2004), a influência de seu estado de protonação (Czodrowski et al., 
2007; Tripathi et al., 2007), pontes de hidrogênio (Trylska et al., 2004) e influência de polimorfismos de diferentes subtipos na influência de mutações de resistência (Batista et al., 2006). Estudos que contribuíram para desenvolvimento de novas abordagens de simulação molecular (Kalra et al., 2001) e predição de mecanismos de resistência (Hou et al., 2009).

\subsection{A Epidemia do estado de São Paulo e o projeto VGDN}

Durante o projeto da Rede de Diversidade Genética Viral VGDN (Pardini et al., 2008), realizado em parte pelo laboratório, foram coletadas 1279 amostras de pacientes de diferentes regiões do Estado de São Paulo: os municípios de Araçatuba, Botucatu, Presidente Prudente, Ribeirão Preto, São J osé do Rio Preto, São Paulo, São Vicente e Sorocaba. Dos 1083 pacientes que tiveram alguma região gênica sequenciada, 152 foram classificados como recombinantes $\mathrm{BF}$, inferidos com base em fragmentos com evidência de recombinação entre um ou mais subtipos, ou com dois ou mais fragmentos puros, mas de subtipos discordantes entre si (Melo, 2011). Entre estes, duas CRFs e outras URFs BF constituem os únicos isolados de BF até o momento (Melo et al., 2011). São Vicente apresentou cerca de 30\% de amostras recombinantes $\mathrm{BF}$, cenário esperado para região (de Souza et al., 2008; Teixeira et al., 2010), enquanto Sorocaba apresentou surpreendentes $22,6 \%$ de recombinantes, e os demais municípios 15\% ou menos (Melo, 2011). E parte das amostras de Sorocaba classificadas como puras tiveram apenas uma região sequenciada, o envelope do subtipo F, e possivelmente são recombinantes em outras porções do genoma.

A prevalência inesperada de recombinantes BF na cidade de Sorocaba, e números altos para outras cidades do interior do estado que também passam por uma epidemia mais nova, com datas de HIV+ mais recentes, revelam a importância de se observar a epidemia de HIV-1 no Brasil fora das capitais e regiões próximas, alvo da maioria dos estudos realizados (Melo, 2011). Junto da classificação das regiões de vírus sequenciados em apenas uma porção com fragmentos puros de recombinantes, e a evidência de eventos independentes e dispersos de recombinação gerando URFs continuamente, os resultados apontam para uma epidemia de recombinantes subestimada (Melo, 2011).

Dos 152 recombinantes $\mathrm{BF}, 101$ possuem um ponto de quebra estimado dentro do gene pol, grande parte deles com uma protease do subtipo F (Melo, 2011). 
Constatação concordante com a noção de que pol seria uma região propensa à recombinação, especialmente entre os subtipos B e F na região da América do Sul (Zhang et al., 2010). Mas, preocupante, por sugerir que recombinantes de origens distintas convergiram para manter uma protease $\mathrm{F}$, possivelmente por possuir valor evolutivo. 


\section{OBJ ETIVOS}

compreender a dinâmica de geração de recombinantes $\mathrm{BF}$ amostrados na epidemia do estado de São Paulo, se eles são derivados de um fenômeno de recombinação comum ou de eventos distintos e convergentes

entender o espalhamento dos recombinantes portadores da protease $\mathrm{F}$, se eles possuem uma vantagem evolutiva que pode ajudar a explicar seu crescimento apesar de uma epidemia do subtipo B já estabelecida

avaliar propriedades da protease $\mathrm{F}$ encontrada com frequência em recombinantes que possam explicar sua presença

construir um clone infeccioso recombinante $\mathrm{BF}$ com a protease $\mathrm{F}$ que permita avaliar o fitness viral e o desempenho da protease sob desafio de inibidores 


\section{MATERIAIS E MÉTODOS}

\subsection{Tratamento de sequências}

\subsubsection{Subtipagem e análise dos perfis de recombinação}

Para a escolha e agrupamento de sequências para análise da dinâmica evolutiva, é necessária uma reavaliação da subtipagem e do perfil de recombinação das sequências de HIV-1 do projeto VGDN e referências depositadas no banco de dados de HIV de Los Alamos (http://www.hiv.lanl.gov). Estas sequências foram alinhadas com o programa CLUSTAL W (Larkin et al., 2007), e os alinhamentos foram editados manualmente no programa Se-Al (Rambaut, 1996) em casos de erros do algoritmo de alinhamento progressivo. A análise de perfil de recombinação foi feita com o programa jpHMM (jumping profile hidden Markov model) (2006; Schultz et al., 2009). A detecção de sequências de DNA recombinantes depende da amostragem das sequências parentais ou linhagens relacionadas a elas, que permitam recuperar a informação sobre ancestralidade, e da presença de polimorfismos informativos que permitam sua diferenciação no mosaico formado. Também é necessário que o evento de recombinação seja recente o suficiente para que tais polimorfismos continuem presentes.

Os algoritmos de detecção de recombinação podem ser agrupados de acordo com a metodologia utilizada. De maneira geral, quase todos seguem o método da janela deslocante, um intervalo de nucleotídeos da sequência testada que são analisados em relação à mesma posição em sequências de referência. A indicação da recombinação ocorre quando uma destas janelas apresenta mais afinidade com uma sequência parental discordante da mais próxima para o restante do genoma (Salminen e Martin, 2009).

A comparação par a par, como a encontrada em métodos de distância empregados em programas como SimPlot (Salminen et al., 1995; Lole et al., 1999), detecta mudanças no padrão de distância genética e assume que as sequências da janela de amostragem mais parecidas são evolutivamente relacionadas, o que não necessariamente ocorre entre sequências muito variáveis (Salminen e Martin, 2009), deixando a desejar na reconstrução da ancestralidade. Além de estar muito sujeita à 
escolha de sequências candidatas a parentais utilizadas na comparação. Métodos estatísticos baseados em mutações, como a detecção de distribuição de substituições utilizada nos programas GENECONV (Sawyer, 1989) e RDP3 (Martin et al., 2010a), e métodos de compatibilidade, possuem a vantagem de detectar recombinação mesmo quando não há suporte filogenético, mas assumem que sítios idênticos são filogeneticamente próximos, sofrendo o mesmo problema com a inferência de ancestralidade de métodos de distância. Já os métodos baseados em reconstrução filogenética, implementados em programas como DualBrothers (Suchard et al., 2002; Minin et al., 2005) e RDP3, tem como princípio a relação evolutiva, mas perdem a resolução em regiões da janela móvel onde o suporte filogenético é baixo, sofrendo com a falta de polimorfismos informativos.

Por outro lado, o programa jpHMM cria um perfil HMM (hidden Markov model) de transição de estados - neste caso polimorfismos - ao longo de um caminho - o genoma completo de sequências de referência de cada subtipo utilizado. Assim, são criados perfis HMM de cada subtipo baseados nas sequências de referência adotadas, o que possibilita a inclusão de informação populacional de polimorfismos na geração de um perfil probabilístico ao invés de contar somente com parentais putativos sem relação de descendência coerente. A sequência testada para recombinação é alinhada e tem seu perfil HMM determinado para a região de interesse, podendo saltar entre os perfis de referência, sem depender do sinal contido em uma região de janela móvel (Schultz et al., 2006). Dos saltos de seu perfil, regiões onde ele é mais compatível com um grupo de referência do que outro é possível determinar a sequência parental de cada região, permitindo a estimativa de um ponto de quebra e regiões de incerteza em seu entorno (Schultz et al., 2009) que definem porções onde o subtipo parental não pode ser determinado com precisão (Figura 12). 
Figura 12 - Exemplo de arquivo de saída do programajpHMM, com as probabilidades de perfil de cada subtipo para uma porção da sequência.

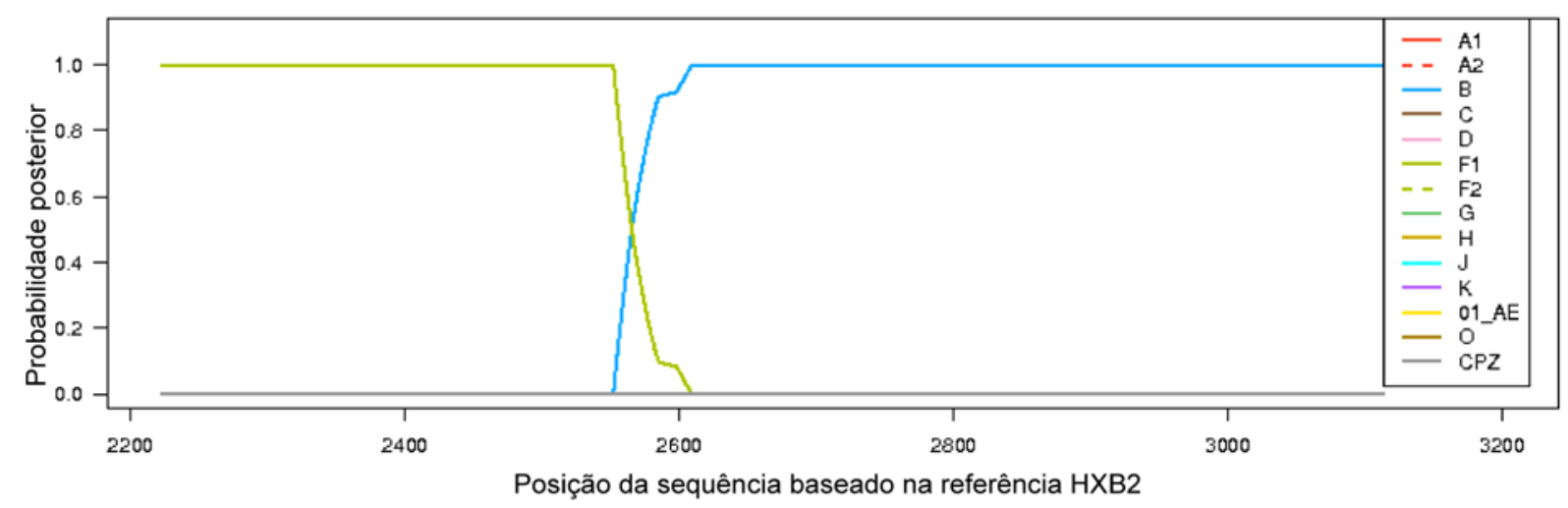

Regiões de incerteza são aquelas com probabilidade posterior inferior a 0,95. Fonte: Iamarino (2012).

Da comparação com o SimPlot, o jpHMM foi significativamente mais acurado para determinar os pontos de quebra, tanto sua posição quanto regiões de incerteza ao redor, e ambos foram melhores do que os demais programas usados para o HIV (Schultz et al., 2006). Outra vantagem do programa jpHMM é que o perfil de HMM usado é construído com base em diferentes alinhamentos. Sua região de menor acurácia são as pontas dos genomas (Schultz et al., 2009), que não formam perfis informativos, e não foram utilizadas nas análises aqui descritas, visto que as regiões sequenciadas dos pacientes analisados pertencem aos genes gag, pol e env. Dadas estas vantagens sobre os outros métodos, as análises de recombinação das sequências utilizadas foram feitas pelo programajpHMM.

\subsubsection{Filodinâmica}

Diferentes métodos podem ser empregados para estabelecer a relação de ancestralidade de sequências, a reconstrução filogenética. O método de parcimônia se baseia na minimização dos eventos de substituição (mudanças de estado) ao longo da árvore (Hennig, 1966), assumindo que sequências com menor distância genética são as mais próximas. Porém, no caso de sequências divergentes e taxas de substituição como as do HIV, a parcimônia sofre de agrupamentos artificiais de taxa, o fenômeno da atração dos ramos longos (Felsenstein, 1988). A máxima parcimônia é útil quando há pouca informação acerca da natureza probabilística do processo de mudança de estado de caracteres, como a reconstrução de caracteres morfológicos ou movimento entre localidades geográficas. Os métodos de distância dependem em sua maioria de 
taxas de substituição uniformes, e são métodos de reconstrução que não permitem a exploração de diferentes topologias, além de reduzir a informação que pode ser extraída da reconstrução à distância entre sequências (Steel et al., 1988). Tais métodos são úteis quando há pouca estrutura em árvores filogenéticas, característica de processos onde a incorporação serial de sinapomorfias é mínima, comum em processos demográficos de crescimento intenso.

Outro método, a máxima verossimilhança também busca o menor número de eventos para reconstruir uma árvore filogenética, mas permite diferentes modelos de substituição, e pode ser mais robusto e acurado do que os outros métodos em condições particulares (Kuhner e Felsenstein, 1994; Huelsenbeck, 1995). Além disso, ele permite o teste de hipótese através da comparação dos valores de verossimilhança (likelihood ratio test, LRT) (Neyman e Pearson, 1933) entre parâmetros estimados a partir genealogias virais reconstruídas utilizando diferentes parâmetros, e também permite a reconstrução de caracteres como localidades geográficas por programas como o MIGRATE (Beerli e Felsenstein, 2001). Através do algoritmo de otimização de parâmetros da reconstrução por máxima verossimilhança implementado no programa Garli 2 (Genetic Algorithm for Rapid Likelihood Inference) (Zwickl, 2006), foi possível a rápida reconstrução da relação filogenética e o teste de hipótese de monofilia de regiões puras das sequências aqui descritas.

Um método mais recente, a análise Bayesiana proposta em 1996 (Rannala e Yang, 1996) também permite a estimativa da probabilidade posterior de diferentes parâmetros. Por não se basear na busca por uma melhor árvore, e sim o conjunto de árvores visitado em estacionariedade durante corridas de Monte Carlo por cadeia de Markov (MCMC) que melhor informam o denominador da fórmula de Bayes para o cálculo da probabilidade posterior, ela permite a variação e estimativa de diversos parâmetros como o tamanho efetivo de população, taxa de substituição e tempo de divergência. O uso de análise Bayesiana em HIV já demonstrou, por exemplo, que o intervalo de transmissão entre homossexuais (6 meses) (Lewis et al., 2008) é mais curto do que o de heterossexuais (14 meses) (Hughes et al., 2009), e pode explicar a rápida dinâmica da epidemia neste grupo de risco. Estes métodos estão implementados no programa BEAST 1.6.2 (Drummond e Rambaut, 2007), utilizado para a reconstrução filodinâmica das sequências aqui analisadas (Bello et al., 2012). A convergência de valores das corridas foi estimada através de valores de tamanho de amostra efetivo (Effective Sample Size, ESS) maiores do que 200, e os testes de 
parâmetros como modelo de crescimento da população foram comparados através de valores logarítmicos de Bayes factor (Bf) maiores do que 20, ambos implementados no programa TRACER (Rambaut e Drummond, 2007).

Após a reavaliação das sequências e determinação dos perfis de recombinação dos mosaicos BF, foi possível separar as sequências recombinantes em regiões puras utilizadas na análise filodinâmica para estimativas de origem ancestral dos fragmentos $\mathrm{B}$ e $\mathrm{F}$ dos recombinantes, teste de monofilia de recombinantes que compartilham pontos de quebra similares, e estimativas populacionais de crescimento.

\subsubsection{Estimativa de seleção e fitness}

A partir das estimativas de relação filogenética e crescimento de porções puras de recombinantes, foi possível estimar importantes parâmetros evolutivos indicadores do papel destes vírus na epidemia. Uma das estimativas foi a medida de seleção $(\omega)$ dos códons, através da razão do número de substituições não sinônimas (dN, representa substituições que implicam na mudança do aminoácido codificado) e o número de substituições sinônimas (dS, substituições que não implicam em mudança de aminoácido), levando em conta a posição do sítio na sequência codante. Regiões sob ataque do sistema imune sofrem pressão diversificadora para se diferenciarem e deixarem de ser reconhecidas, registrando mais substituições não sinônimas do que sinônimas $(\mathrm{dN} / \mathrm{dS}$ ou $\omega>1)$. Ao passo que regiões que desempenham funções importantes e dependentes de aminoácidos conservados registram mais mutações sinônimas do que não sinônimas $(\omega<1)$. Estas análises foram realizadas pelo programa HyPhy (Pond et al., 2005), que corrige a estimativa dos coeficientes de seleção $\omega$ usando a relação filogenética, através de métodos de análise como FEL (fixed effect likelihood) e REL (randon effect likelihood), que estimam as taxas por sítio, e o SLAC (single likelihood ancestor counting), que leva em conta uma sequência ancestral estimada.

Além da relação filogenética entre as sequências, os valores de população efetiva estimados (Ne.g) pelo programa BEAST permitem o cálculo do coeficiente de seleção $\mathrm{s}$ e do fitness absoluto $\mathrm{w}_{\text {abs }}$ dos fragmentos, medidas de reprodução diferencial que apontam quais alelos são mais favorecidos em relação aos correspondentes de outros subtipos, ou apenas carregados como consequência de eventos de recombinação sem 
valor evolutivo. Um alelo sendo propagado sob neutralidade em uma população haplóide é fixado em média após $2 \mathrm{Ne}$ gerações, e quanto menor o tempo $t$ de fixação em relação ao esperado sob neutralidade, maior o coeficiente de seleção s atuando na fixação daquele alelo, aproximada pela razão $s=\log _{e}(2 N) / t$, esperada em populações ideais de Wright e Fisher (Nei, 1987). Como a diferença observada no gene nef, com substituições fixadas em um paciente hemofílico em um período de 30 meses, mais rápido do que o esperado de $\sim 89$ meses sob neutralidade (Zanotto et al., 1999). Já o fitness absoluto $\left(\mathrm{w}_{\text {abs }}\right)$ pode ser calculado pela diferença entre o tamanho de população efetiva de uma geração em relação à geração anterior ( $w_{\text {abs }}=N e \cdot g_{t} / N e . g_{t}$ 1) (Hartl e Clark, 1989), empregado para a comparação entre populações do subtipo $B$ e recombinantes $\mathrm{BF}$.

\subsection{Dinâmica Molecular}

Informações sobre a função e estrutura de uma proteína interagindo com um substrato podem ser obtidas por métodos como a difração de raios X. Porém, o método de difração fornece uma imagem estática derivada da média das posições atômicas do sistema, e o processo de cristalização induz a formação de complexos e dobramentos estruturais que não necessariamente correspondem a estruturas que ocorrem naturalmente. Por outro lado, simulações da interação entre proteínas e o substrato através de dinâmica molecular são ferramentas computacionais de grande auxílio na compreensão de sua interação. Ao contrário da cristalografia de raios X, a dinâmica molecular produz dados ao longo do tempo, o que permite a observação de flutuações atômicas, formação de pontes de hidrogênio, mudanças de conformação e de torção de ligações, bem como medidas diretas de afinidade como a energia de ligação. Por ser um processo interativo, permite mudanças de condições de corrida como: $\mathrm{pH}$, temperatura, substratos, solvatação, etc. Ademais a dinâmica molecular permite o uso de estimadores das incertezas do posicionamento atômico, o que permite uma análise mais completa, quando embasada em informações experimentais acerca das moléculas de referência. 
Tabela 1 - Proteases B e F escolhidas (pacientes nomeados de acordo com o número de referência dentro do projeto VGDN) e o perfil de subtipo por região genômica e genotipagem de resistência para cada inibidor de protease

\begin{tabular}{cccccccccc} 
& \multicolumn{1}{c}{ Subtipo por região genômica } & \multicolumn{8}{c}{ Grau de resistência a PIs } \\
\hline Paciente & gag & protease & polimerase & env & ATV & IDV & LPV & NFV & SQV \\
\hline $\mathbf{0 0 6 3}$ & - & F & B & B & 3 & 1 & 2 & $\mathbf{3}$ & 4 \\
$\mathbf{0 0 8 7}$ & - & F & F & - & 3 & 0 & 2 & $\mathbf{3}$ & 4 \\
$\mathbf{0 4 5 0}$ & F & F & F & F & 3 & 1 & 2 & $\mathbf{3}$ & 4 \\
$\mathbf{0 7 3 2}$ & - & F & BF & B & 3 & 0 & 2 & $\mathbf{3}$ & 4 \\
$\mathbf{0 4 4 9}$ & - & B & B & F & 3 & 1 & 3 & $\mathbf{3}$ & 4 \\
$\mathbf{0 8 0 5}$ & B & B & B & B & 4 & 4 & 4 & $\mathbf{4}$ & 4 \\
$\mathbf{1 1 2 0}$ & - & B & BF & - & 2 & 1 & 2 & $\mathbf{3}$ & 3 \\
$\mathbf{1 2 1 8}$ & B & B & B & - & 3 & 4 & 3 & $\mathbf{4}$ & 3 \\
$\mathbf{1 2 2 7}$ & - & B & B & - & 4 & 4 & 3 & $\mathbf{4}$ & 4 \\
\hline
\end{tabular}

Grau de resistência de acordo com Stanford University HIV Drug Resistance Database:

0 - sensível

1 - possivelmente sensível

2 - 0 baixo grau de resistência

3 - grau intermediário de resistência

4 - alto grau de resistência

PIs:

ATV: atazanavir

IDV: indinavir

LPV: lopinavir

NFV: Nelfinavir

SQV: saquinavir

Fonte: Iamarino (2012).

Para comparar as propriedades conferidas por mutações de resistência primária e a influência de polimorfismos e mutações secundárias na resistência a drogas em proteases do subtipo $\mathrm{BF}$, foram escolhidas proteases $\mathrm{F}$ de recombinantes e proteases B com mutações de resistência primárias similares (ANEXO A). Estudos anteriores de dinâmica de protease e resistência a inibidores tiveram suas sequências determinadas artificialmente, substituindo-se os aminoácidos de interesse em um backbone comum, a estrutura de determinadas proteases resolvidas por cristalografia de raios X (Ode et al., 2005; Batista et al., 2006; Kozisek et al., 2007). Embora sejam elucidativos, tais estudos ignoram as mutações secundárias envolvidas na restauração da atividade enzimática e criam combinações de aminoácidos que não necessariamente ocorreriam in vivo. Para evitar tal viés, foram escolhidas para a dinâmica molecular apenas sequências extraídas de pacientes, que reconhecidamente ocorreram em conjunto. 
Tabela 2 - Mutações primárias e mutações associadas à resistência de cada protease escolhida de acordo com Stanford University HIV Drug Resistance Database.

\begin{tabular}{|c|c|c|c|c|c|c|c|c|c|c|}
\hline \multirow[b]{2}{*}{ Paciente } & \multirow[b]{2}{*}{ protease } & \multicolumn{5}{|c|}{ Mutações primárias por região } & \multicolumn{4}{|c|}{ Mutações associadas à resistência } \\
\hline & & $\mathbf{F}$ & $\mathbf{P}$ & $\mathbf{F}$ & $\mathbf{P}$ & I & & & & \\
\hline 0063 & $\mathbf{F}$ & & & $154 \mathrm{~V}$ & & L90M & L10V & & & \\
\hline 0087 & $\mathbf{F}$ & M46L & & & V82A & & & & & \\
\hline 0450 & $\mathbf{F}$ & & G48V & I54T & V82A & & L10V & & & T74S \\
\hline 0732 & $\mathbf{F}$ & M46L & & & V82A & & & & & T74S \\
\hline 0449 & B & M46I & & & & L90M & L10। & & G73S & \\
\hline 0805 & B & M46I & & $154 \mathrm{~V}$ & V82A & L90M & L10। & & G73S & \\
\hline 1120 & B & & & $154 \mathrm{~V}$ & V82A & & L10I & A71T & & \\
\hline 1218 & B & M46L & & $154 \mathrm{~V}$ & V82A & & L10F L24I L33F Q58E & A71V & & \\
\hline 1227 & B & & G48V & $154 \mathrm{~V}$ & V82A & & L10I & A71V & & T74S \\
\hline
\end{tabular}

Pacientes nomeados de acordo com o número de referência dentro do projeto VGDN Regiões:

F - flap

$\mathrm{P}$ - próximo ao bolso do substrato

I - interior da protease

Fonte: Iamarino (2012).

A parametrização e estrutura do inibidor escolhido para a simulação, o nelfinavir, foi desenhada e gentilmente cedida pelo grupo do professor Pedro Pascutti (Silva, 2003). As proteases foram submetidas à genotipagem de resistência no servidor da Stanford University HIV Drug Resistance Database (http:// hivdb.stanford.edu). Quatro proteases F apresentaram resistência a nelfinavir e foram selecionadas (Tabela 1). Para comparação com o subtipo B, foram escolhidas proteases B com as combinações mais próximas das mutações de resistência do subtipo $\mathrm{F}$, originadas em vírus do subtipo B ou recombinantes BF (Tabela 2). Nem todos os pacientes escolhidos foram tratados com este nelfinavir, ou mesmo com PIs em geral (Tabela 3 e ANEXO A). 
Tabela 3 - Tratamento antirretroviral contendo inibidor de protease a que os pacientes foram submetidos.

\begin{tabular}{|c|c|c|c|c|c|c|c|c|c|c|c|c|c|c|c|c|}
\hline \multirow[b]{2}{*}{ Paciente } & \multirow[b]{2}{*}{ protease } & \multicolumn{3}{|c|}{ Primeiro tratamento } & \multicolumn{3}{|c|}{ Segundo tratamento } & \multicolumn{3}{|c|}{ Terceiro tratamento } & \multicolumn{3}{|c|}{ Quarto tratamento } & \multicolumn{3}{|c|}{ Quinto tratamento } \\
\hline & & PI & início & fim & PI & início & fim & PI & início & fim & PI & início & fim & PI & início & fim \\
\hline 0063 & $\mathbf{F}$ & IDV & Fev/97 & Nov/98 & RTVISQV & Nov/99 & Abr/00 & NFV & Jun/00 & Mar/01 & & & & & & \\
\hline 0087 & $F$ & IDV & Nov/96 & Fev/98 & RTVISQV & Ago/98 & Mai/99 & SQVINFV & Mai/99 & Jul/99 & NFV/IDV & Jul/99 & Mar/01 & & & \\
\hline 0450 & $F$ & SQV & Mai/96 & Fev/98 & IDV & Fev/98 & Jun/02 & LPV & Jun/02 & Ago/03 & & & & & & \\
\hline 0732 & $\mathbf{F}$ & sem tratan & ento com & inibidor d & le protease & & & & & & & & & & & \\
\hline 0449 & B & NFV & Mai/00 & Ago/03 & & & & & & & & & & & & \\
\hline 0805 & B & SQV & Fev/97 & $?$ & NFV & Mai/99 & Out/01 & RTV/IDV & Out/01 & Abr/02 & RTVISQV & Nov/03 & Jan/04 & IDV & Jan/04 & Ago/04 \\
\hline 1120 & B & RTV & Ago/97 & Jul/98 & IDV & $\mathrm{Jul} / 98$ & Mai/03 & * & Mai/03 & Ago/04 & & & & & & \\
\hline 1218 & B & RTV & Out/97 & Set/99 & LPVr & Dez/03 & Mar/04 & & & & & & & & & \\
\hline 1227 & B & RTV/IDV & Set/01 & Mai/04 & RTVIATV & Jun/04 & Ago/04 & & & & & & & & & \\
\hline
\end{tabular}

O último tratamento antes da amostragem está em itálico. O paciente 0732 nunca foi tratado com PIs.

PIs:

ATV: atazanavir

IDV: indinavir

LPV: lopinavir

LPVr: lopinavir + ritonavir

NFV: Nelfinavir

RTV: ritonavir

SQV: saquinavir

*sem PIs no tratamento no período

Fonte: Iamarino (2012). 


\subsubsection{Modelagem por homologia}

Uma grande vantagem da dinâmica molecular e sua parametrização de propriedades de moléculas biológicas é a simulação de biomoléculas e compostos de estrutura ainda não caracterizada. Dentre as moléculas biológicas, devido à grande variedade de aminoácidos, as proteínas podem adotar as mais variadas conformações, o que ainda impossibilita a estimativa de sua estrutura com base apenas na composição dos resíduos para cadeias mais longas do que pequenos peptídeos (Baker e Sali, 2001).

Evolutivamente, a estrutura tridimensional de proteínas é mais estável e resistente a mudanças do que a sequência nucleica que a codifica (Chothia e Lesk, 1986; Sander e Schneider, 1991), de maneira que sequências similares correspondem a estruturas bastante parecidas. Isso permite a reconstrução de proteínas que ainda não tiveram sua estrutura resolvida por difração de raios X ou ressonância magnética nuclear a partir de moléculas de sequência similar de estrutura conhecida, através da modelagem por homologia (Krieger et al., 2005).

A similaridade necessária para a modelagem com acurácia varia entre 20 e 30\% de identidade, para proteínas com 100 ou mais aminoácidos (Rost, 1999), enquanto sequências com mais de $90 \%$ de homologia podem ser reconstruídas com precisão bastante próxima de estruturas reconstruídas por cristalografia (Chothia e Lesk, 1986). A modelagem por homologia começa com o alinhamento da sequência alvo com uma ou mais proteínas molde com estrutura tridimensional resolvida, com a maior homologia possível. Com base neste alinhamento é desenhado o esqueleto proteico do modelo, com as estruturas secundárias mais conservadas, como folhas $\beta$ e $\alpha$-hélices. Sobre este esqueleto são adicionados os loops, estruturas mais flexíveis e variáveis, as cadeias laterais são acrescentadas posteriormente. O modelo é otimizado através de minimização energética, para eliminar torções e conformações de cadeia lateral desfavoráveis.

Para contornar as diferentes conformações que os loops podem adotar, pode ser usada a estrutura de outros loops de sequência similar que já tenham a estrutura resolvida, ou a minimização energética durante a otimização estrutural. Já as possíveis conformações de rotâmeros de cadeia lateral podem ser eliminadas com o uso de bancos de conformações baseados no posicionamento do esqueleto proteico de dados empíricos (Dunbrack e Karplus, 1994; Chinea et al., 1995). 
A validação dos modelos foi feita com base na estrutura tridimensional, através de diferentes métodos, como a comparação com a estrutura molde, a conservação de estruturas importantes e validação estereoquímica (Marti-Renom et al., 2000). Programas como o PROCKECK (Laskowski et al., 1993) avaliam propriedades estruturais como tamanho, ângulo de ligação e de torção de ligações, bem como a quiralidade e posicionamento de cadeia lateral dos aminoácidos.

As proteases escolhidas foram desenhadas no programa MODELLER (Sali e Blundell, 1993). A protease controle B adotada foi o cristal resolvido com o inibidor nelfinavir 1OHR (Kaldor et al., 1997), e as proteases B de pacientes foram posteriormente modeladas com base em sua estrutura. Já a protease $\mathrm{F}$ foi baseada no cristal da protease F selvagem de código PDB 2P3C (Sanches et al., 2007b), que possui as mutações I15V, E35D, M36I, S37A, R41K, R57K, D60E, Q61N, I62V, L63S, I64L, e L89M. A protonação dos resíduos de asparagina segue seu pI, levando-se em conta o pH ótimo da protease como 5. A validação dos modelos foi feita através do programa Procheck (Laskowski et al., 1996) e visualização através do programa VMD (Humphrey et al., 1996). As moléculas de água presentes na estrutura resolvida foram mantidas na modelagem.

\subsubsection{Interação Molecular}

Existem diversos métodos para se representar, simular e estudar a interação entre moléculas, entre eles a mecânica quântica (QM), Monte Carlo, mecânica molecular (MM) e sua aplicação, a dinâmica molecular (MD). A diferença entre eles está na complexidade dos modelos atômicos e dos campos de força utilizados, escolhidos de acordo com o tipo de propriedade a ser estudada e o custo computacional envolvido. O cálculo das interações é feito em intervalos de tempo definidos. Intervalos de tempo muito curtos cobrem apenas uma fase da interação, e intervalos muito longos podem violar distâncias de interação e introduzir instabilidades devido à sobreposição de átomos (Leach, 2001).

O método de Monte Carlo é a técnica mais antiga, usada nas primeiras simulações (Leach, 2001). Ele consiste em mudanças aleatórias e correções de orientação e conformação nos átomos do sistema estudado. A partir destas posições, é possível calcular a energia potencial do sistema sem precisar considerar a variável tempo. Porém, sua aplicação direta é limitada a sistemas simples constituídos por 
moléculas relativamente rígidas, como gases. Em sistemas com moléculas complexas, como biopolímeros, as mudanças de posição feitas em cada passo são muito pequenas para cobrir todas as conformações possíveis, além de causarem alterações drásticas em outros pontos de uma longa cadeia de átomos (Leach, 2001), a não ser que grandes restrições sejam incorporadas.

Apenas a mecânica quântica permite o estudo de propriedades derivadas da distribuição eletrônica do átomo (Leach, 2001), além de levar em conta a estrutura nuclear (Schlick, 2010). Ela é capaz de simular formas intermediárias de reações e a formação e quebra de ligações atômicas, incluindo aquelas que ocorrem durante a catálise enzimática (Warshel et al., 2006; Zhang, 2006). Porém, o volume de cálculos necessários limita sua aplicação a sistemas mais simples, com poucos átomos (Schlick, 2010). Da combinação de métodos de QM e MM, é possível o estudo de sistemas maiores do que apenas algumas moléculas (caso de QM) e ainda obter parâmetros atômicos, que possibilitam, por exemplo, o estudo de intermediários de reações enzimáticas (Warshel, 2002) de grande importância para sistemas biológicos (Boero et al., 2007). Para isso, uma pequena parte do sistema é representada em detalhes por QM, enquanto regiões menos importantes ao seu redor são descritas apenas pela mecânica molecular (Acevedo eJ orgensen, 2010).

\subsubsection{Mecânica Molecular}

A mecânica molecular considera o átomo como uma partícula única em um sistema newtoniano, ignorando a configuração eletrônica, e calcula a energia do sistema com base apenas no movimento e conservação de momento das partículas (Leach, 2001) (Figura 13). Por mais que esta abordagem mais simplificada não forneça informação sobre interações que dependem dos elétrons, o aumento de desempenho proporcionado permite que sejam estudados sistemas com muito mais átomos do que aqueles viáveis em mecânica quântica. Por este motivo, o método empregado para estimar a interação entre as proteases de interesse e o inibidor nelfinavir, um dos principais PIs adotados pelo Brasil durante o período anterior à coleta do projeto VGDN (Nunn et al., 2007), foi a dinâmica molecular, aplicação da mecânica molecular, usando o programa GROMACS versão 3.3.3 (Van Der Spoel et al., 2005). 
Figura 13 - Molécula de propano e potencias locais considerados na mecânica molecular.

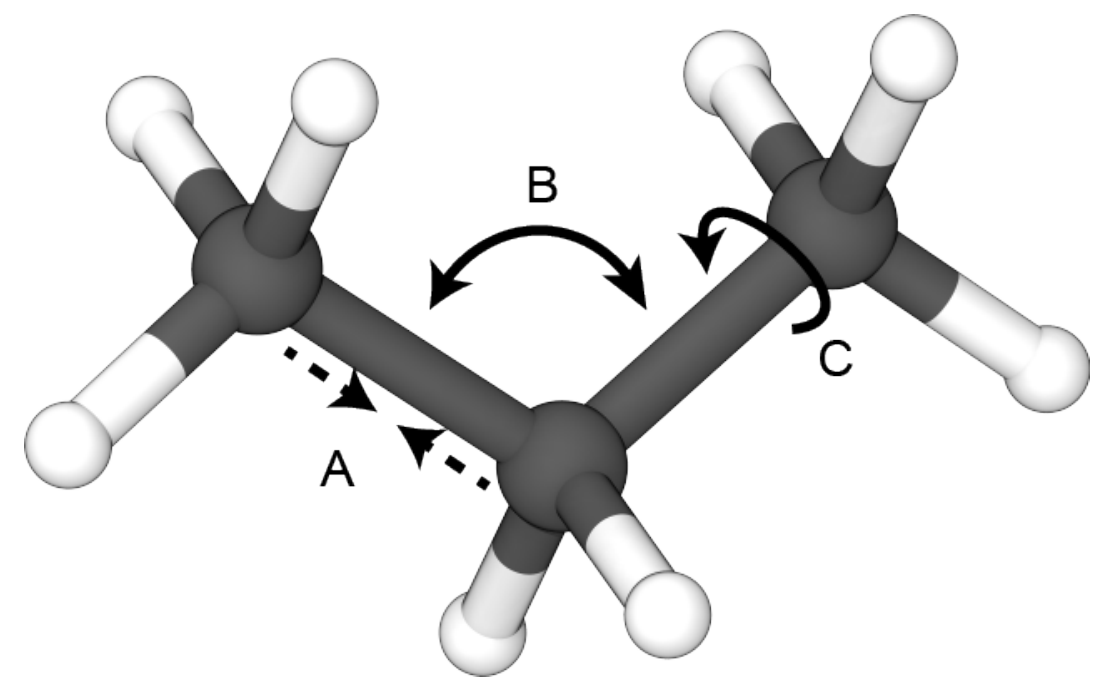

O potencial elástico de ligação (A), o potencial de mudança angular (B) e o potencial de torção da ligação (C).

Fonte: Iamarino (2012).

A mecânica molecular se baseia em campos de força construídos com base na aplicação de medidas obtidas em sistemas mais simples. As interações e a energia molecular são medidas com base em energias de ação local: potenciais harmônicos de rotações e mudanças angulares de ligações, e o potencial harmônico da elasticidade da ligação; e energias de ação distante: os potenciais de Lennard-Jones e de Coulomb. Separar as energias em local e distante permite que os programas de dinâmica molecular otimizem seus valores em frequências distintas e otimizem os ciclos de cálculo (Schlick, 2010). Da mesma forma, podem ser usadas restrições de ângulos de torção e distância de interação para reduzir o espaço amostral e graus de liberdade necessários e acelerar as simulações. 
Figura 14 - Gráfico do Potencial de Lennard-J ones.

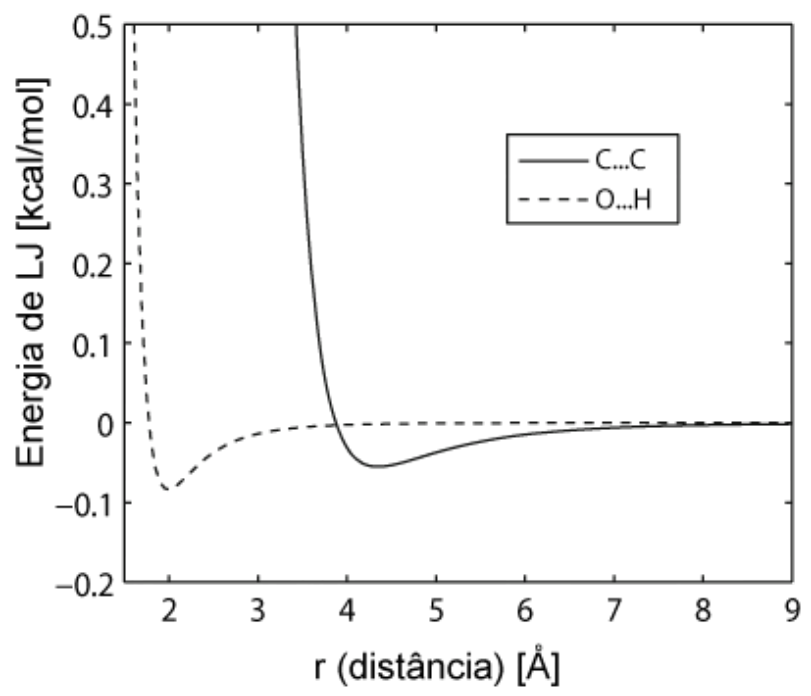

Energia potencial entre dois pares de átomos (carbono/ carbono e oxigênio/ hidrogênio.

Fonte: Iamarino (2012).

O potencial de Lennard-J ones (LJ) mede a formação temporária de dipolo decorrente da flutuação na distribuição de elétrons ao redor do núcleo conforme dois átomos se afastam (força de van der Waals) e deixam de sofrer a repulsão entre elétrons e internuclear (repulsão de Pauli). Como o potencial diminui rapidamente com a distância entre átomos (Figura 14), ele tende a ser considerado apenas dentro de um cutoff que costuma ser de 8 a $9 \AA$ (Mackerell, 2004). Para as análises aqui descritas, foi adotado o campo de força GROMOS96 (Van Der Spoel et al., 2005), que assume um cutoff de $16 \AA$. 
Figura 15 - Gráfico do Potencial de Coulomb.

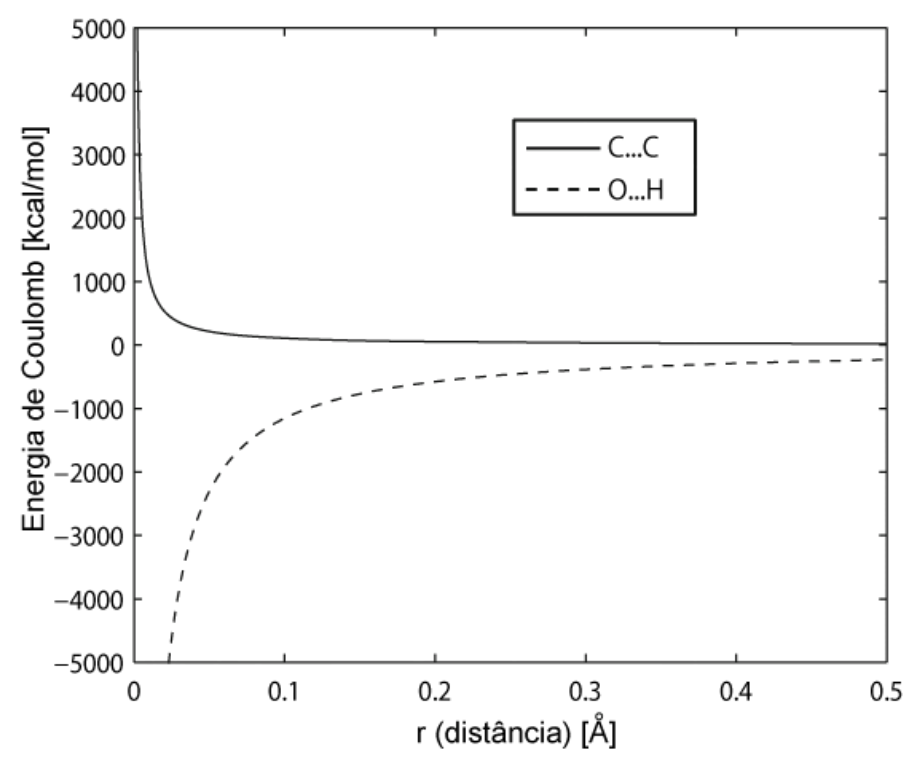

Energia potencial entre pares de átomos de mesma carga (carbono/ carbono) e cargas opostas (oxigênio/ hidrogênio).

Fonte: Iamarino (2012).

O potencial de Coulomb provém da energia de partículas carregadas, através da interação iônica. Essa energia é positiva para partículas de mesma carga, e negativa para partículas de carga oposta. O maior problema da interação eletrostática em simulações está na representação matemática da distribuição de cargas, especialmente a carga negativa, gerada pela nuvem elétrons, que deveria ser uniforme ao longo de todo átomo, mas podem ser representadas como multipolares ou bipolares sem grandes perdas (Sagui e Darden, 1999). Por atuar a uma distância maior do que o potencial de LJ (Figura 15) é mais importante para estabilização de solventes e para interação entre resíduos distantes, e seu valor de cutoff costuma ser igual ou maior do que $12 \AA$ (Schlick, 2010). O campo de força GROMOS96 (Van Der Spoel et al., 2005) aqui usado assume um cutoff de $14 \AA$.

\subsubsection{Condições periódicas}

Com o aumento exponencial de átomos em sistemas mais complexos, a adoção do cutoff de interação interatômica é necessária para a redução do volume de cálculos, especialmente ao considerar a distância de ação do potencial de Coulomb (Warshel e Russell, 1984). Este método de corte pode ser abrupto (truncation), diminuir a partir de um ponto sem alterar as condições próximas do átomo (switch) 
ou diminuir gradualmente até a fronteira (shift) (Steinbach e Brooks, 1994). Independente da distância, é preciso respeitar a conservação de energia e evitar mudanças abruptas como as provocadas pelo método mais simples, que consiste em uma esfera de corte (truncation).

Um sistema molecular simulado é constituído por um número finito de moléculas, mas é sujeito a forças como o potencial de Coulomb de ação a distâncias teoricamente infinitas, daí a importância de criar condições de fronteira ao redor da simulação, para além das quais as forças são desconsideradas. Estas condições de fronteiras podem ser periódicas ou não periódicas. Em condições não periódicas, o sistema precisa incorporar regiões sob vácuo ao redor do ponto de maior interesse (onde ocorrem as interações modeladas), onde o solvente não atua e não há átomos recebendo a ação de forças, ou regiões onde o solvente é considerado implicitamente pelo modelo de representação de moléculas adotado.

Já sob condições periódicas, as moléculas de interesse são contidas em uma célula, que pode ser um simples cubo de solvente, com suas bordas replicadas infinitamente, de maneira que os átomos na fronteira de uma face interagem com aqueles da face oposta (Figura 16). O formato desta célula pode ser bastante variado, como um cubo, octaedro ou um prisma hexagonal (este último preferível no caso de uma molécula alongada como o DNA). Para evitar a chance de átomos da molécula de interesse interagirem com eles mesmos em uma imagem periódica, são adotados pelo menos $10 \AA ̊$ de moléculas de água ao seu redor (de Souza e Ornstein, 1997). 
Figura 16 - Representação bidimensional de uma caixa periódica em cubo ilustrando como cada porção terminal interage com a interface oposta.

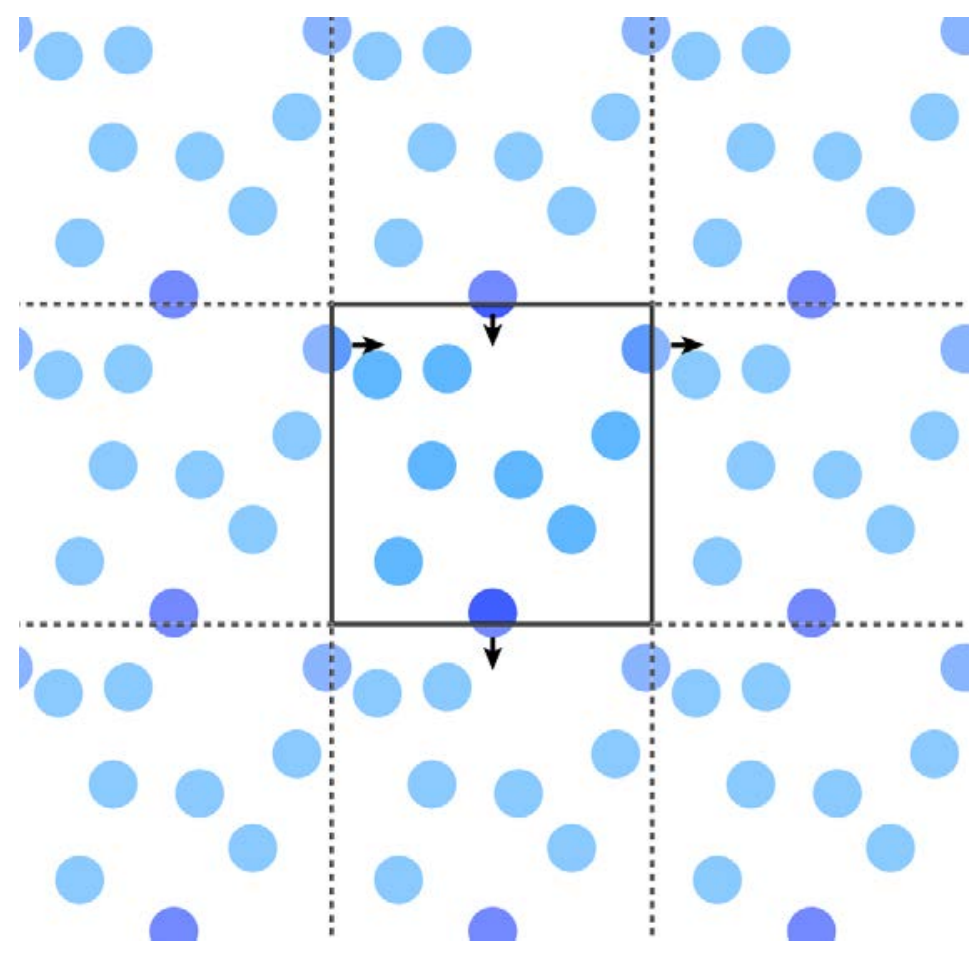

Fonte: Iamarino (2012).

Para que sejam computadas as interações de longa distância sem que um átomo interaja com sua própria imagem, e para que o volume de cálculo seja otimizado, são usados métodos de interpolação dos potenciais em uma trama de cargas ao redor da partícula, que diminui ainda mais a complexidade dos cálculos (Schlick, 2010), como P3M (Hockney e Eastwood, 1981) e aplicações da soma de Ewald que transformam a carga do átomo em uma medida finita e tratável (Sagui e Darden, 1999), como o Particle Mesh Edwald (PME) (Darden et al., 1993; Essmann et al., 1995).

\subsubsection{Campos de força}

A interação entre as moléculas na mecânica molecular é medida através da dinâmica molecular. Para isso, são empregados campos de força, que descrevem a relação entre a estrutura e propriedades das moléculas, como elas vibram, como as ligações se comportam e o valor destas interações (Leach, 2001). Os principais campos de força utilizados para dinâmica molecular de moléculas biológicas, AMBER (Cornell et al., 1995), CHARMM (Brooks et al., 1983), GROMOS (Scott et al., 1999) e OPLS (J orgensen e Tirado-Rives, 1988) utilizam a mesma equação (1) para o cálculo da energia levando em conta os termos para distância e ângulo de ligação ( $E_{\text {lig }}$ e 
Elang), o potencial de torção do ângulo ( $\left.E_{\text {tor }}\right)$ e os potenciais de longa distância de Lennard-J ones $\left(E_{\mathrm{LJ}}\right)$ e de Coulomb ( $\left.E_{\text {coul }}\right)$ :

$$
E=E_{\text {lig }}+E_{\text {lang }}+E_{\text {tor }}+E_{L J}+E_{\text {coul }}
$$

A complexidade do campo dita as aproximações e a quantidade de cálculos necessários, a ligação com o hidrogênio pode ser implícita, e mesmo assim ter sua influência bem calculada (Mackerell, 2004). Da mesma forma, os campos de força podem considerar o solvente (geralmente a água) implícita ou explicitamente. Dentre os modelos explícitos de água, o TIP3P é o mais comum, embora tenha limitações para interações eletrostáticas de longa distância (Feller et al., 1996), efeito corrigido o modelo SPC (Berendsen et al., 1981) implementado no campo de força GROMOS e adotado nas simulações aqui descritas.

No caso das proteínas, os parâmetros do esqueleto peptídico, como medidas de distância, angulares e de giro, são derivados de estudos de mecânica quântica do dipeptídeo de alanina, complementado com medidas de torção de dipeptídeos de prolina e glicina, que não possuem o backbone padrão (Mackerell, 2004). Já os inibidores de protease e outras moléculas orgânicas diferentes daquelas já desenhadas para os campos de força precisam ter estrutura, propriedades e cargas estimadas para cada campo de força através de programas como o Gaussian (Shoichet e Kuntz, 1993).

\subsubsection{Condições da dinâmica}

Para as dinâmicas aqui descritas foi empregado o solvente explícito, um octaedro de água formando uma camada de no mínimo $15 \AA$ ao redor do complexo protease+ligante, composto de entre 10 e 15 mil moléculas de $\mathrm{H}_{2} \mathrm{O}$. Para que a energia livre de ligação possa ser estimada, íons positivos $\left(\mathrm{Na}^{+}\right)$e negativos $\left(\mathrm{Cl}^{-}\right)$ foram adicionados, de maneira a neutralizar a carga do sistema. Com a adição das moléculas de água, foram criadas diversas distâncias interatômicas e pontes de hidrogênio artificiais, artefato que introduz forças e torções que perturbariam o sistema caso a dinâmica fosse iniciada em seguida. Para que o sistema estudado não comece com valores energéticos artificiais foi necessária a minimização energética.

A primeira etapa consistiu em uma minimização energética pelo método de máximo declive (steepest descent) de 5000 passos, onde os átomos foram 
reacomodados em perturbações de $0,01 \mathrm{~nm}$ a cada passo buscando uma diminuição da energia potencial do sistema, com a restrição de posição dos átomos da protease e do ligante, para permitir que o solvente e íons adicionados se acomodassem ao redor das moléculas desenhadas (ANEXO B.1). Em seguida, foi realizada outra etapa de minimização energética pelo método de máximo declive de 5000 passos com perturbações de $0,01 \mathrm{~nm}$, mas desta vez sem a restrição de posição, buscando a minimização energética de todo o sistema e acomodação das moléculas dentro do espaço proteico (ANEXO B.2).

O método de máximo declive não leva em conta interações anteriores, e consiste apenas em passos de perturbação que são aceitos caso diminuam a energia total do sistema, sendo bastante prático como primeira abordagem, mas bastante ineficiente quando próximo do mínimo energético. Após estas duas etapas, foi usado o algoritmo de gradiente conjugado (conjugate gradient), mais custoso computacionalmente, mas mais eficiente para atingir um mínimo energético do que o máximo declive, para equilibrar o sistema usando o método de PME para interações de longa distância e mantendo temperatura e pressão constantes de $300 \mathrm{~K}$ e $1 \mathrm{~atm}$ ao longo de 10 ps de simulação pelo método de acoplamento térmico e de pressão de Berendsen (Berendsen et al., 1984), que permitiu o cálculo de energia livre de Gibbs (ANEXO B.3).

Em seguida, foi realizada a dinâmica molecular, com 500 ps de restrição posicional da protease para completar a solvatação e $10 \mathrm{~ns}$ da simulação completa, sem restrição de posição (ANEXO B.4 e ANEXO B.5). Novamente, o sistema foi mantido em $300 \mathrm{~K}$ e $1 \mathrm{~atm}$, as interações de longa distância foram tratadas pelo método de reaction field (Schreiber e Steinhauser, 1992) e uma constante dielétrica de 54 (Smith e Vangunsteren, 1994). O uso do algoritmo de constrição LINCS (Hess et al., 1997), que permitiu um passo de integração de 2 fs, totalizando 5 milhões de passos de dinâmica irrestrita. Conforme descrito anteriormente, os raios de corte das interações de LJ e de Coulomb foram, respectivamente, $16 \AA$ e $14 \AA$.

\subsubsection{Energia livre de ligação e interação com o ligante}

A energia livre de ligação é uma medida direta da afinidade de interação entre duas moléculas. Este valor permite a comparação de afinidade e eficiência de ligação entre dois ou mais sistemas próximos, como a comparação entre diferentes inibidores 
de uma enzima, ou da ação de diferentes enzimas sobre um mesmo ligante. Ela pode ser descrita pela função de Gibbs, G, mais indicada para sistemas onde temperatura, pressão e o número de partículas são constantes (Leach, 2001), condição experimental da maioria das simulações de dinâmica molecular.

No caso das macromoléculas, o cálculo da energia livre é dificultado pela grande quantidade de configurações possíveis separadas por barreiras de baixa energia, especialmente no caso de sistemas complexos descritos por métodos de otimização como Monte Carlo e dinâmica molecular (Leach, 2001). Para estes métodos, uma aproximação possível é o cálculo de energia livre pela diferença entre sistemas em equilíbrio. No caso da interação entre uma enzima e seu ligante, pode ser usada a diferença de energia entre um sistema da enzima solvatada com ou sem o ligante.

Uma das abordagens mais utilizadas é a perturbação de energia livre (FEP - free energy perturbation), que calcula a energia livre através da diferença de energia $\Delta \mathrm{G}_{2}{ }^{-}$ $\Delta \mathrm{G}_{1}=\Delta \mathrm{G}_{4}-\Delta \mathrm{G}_{3}$ entre simulações que variam entre pelo menos quatro estados: um ligante $L_{1}$ ligado ao um receptor $R\left(L_{1} R\right)$, o ligante desligado $\left(L_{1}+R\right)$, outro ligante e o receptor $\left(\mathrm{L}_{2} \mathrm{R}\right)$, que pode ser o mesmo ligante $\mathrm{L}$, mas sem interações moleculares, e o outro ligante desligado $\left(\mathrm{L}_{2}+\mathrm{R}\right.$ ). . A diferença entre os estados não pode ser drástica, o que limita a comparação entre vários ligantes ou entre mutações de uma mesma enzima (Aqvist et al., 2002).

$$
\begin{array}{ccc}
L_{1}+R & \stackrel{\Delta G_{1}}{\rightarrow} & L_{1}-R \\
\Delta G_{3} \downarrow & & \downarrow \Delta G_{4} \\
L_{2}+R & \stackrel{\Delta G_{2}}{\longrightarrow} & L_{2}-R
\end{array}
$$

Outro método de aproximação foi apresentado por Åqvist e colaboradores foi introduzido em 1994, para o estudo da energia livre de ligação de inibidores de uma pepsina (Aqvist et al., 1994). Através do método semi-empírico de energia linear de interação (LIE, linear interaction energy, Equação 3), a energia livre de ligação $\left(\Delta \mathrm{G}_{\text {lig }}\right.$ ) é dada pela mudança de estado entre a interação do ligante (l) em solução (w) e o ligante dentro de seu receptor proteico (p) (Aqvist et al., 2002). Para condições onde o ligante e o receptor são bem estudados, há grande ganho computacional e boa aproximação de energias medidas (Stjernschantz et al., 2006).

$$
\Delta G_{\text {lig }}(\mathrm{l})=\Delta G_{\text {sol }}^{\mathrm{p}}(\mathrm{l})-\Delta G_{\mathrm{sol}}^{\mathrm{w}}(\mathrm{l})(3)
$$


A energia de ligação $\Delta$ Glig viria então da diferença $\Delta$ da soma das energias não polar (força de van der Waals, $\left\langle V_{l-s}^{v d w}\right\rangle$ ) e polar (eletrostática, $\left\langle V_{l-s}^{e l}\right\rangle$ ) calculadas em simulações do ligante e seu entorno (l-s) em solução livre e ligado ao receptor (Equação 4). Para a interação hidrofóbica, a relação entre a área de contato e o tamanho de cadeia de hidrocarbonetos foi corrigido com um valor de $\alpha$ de 0,0161 inicialmente, para que as medidas de energia fossem compatíveis com a escala de valores experimentais. Da resposta linear entre o solvente e um íon em solvatação, o parâmetro de correção $\beta$ da interação eletrostática considerado tem valor 0,5 e pode variar de acordo com o número de grupos $\mathrm{OH}$ do ligante $(0,43,0,37$ e 0,33 para zero, um e dois ou mais grupos $\mathrm{OH}$, respectivamente) (Hansson et al., 1998).

$$
\Delta G_{\text {lig }}=\alpha \Delta\left\langle V_{l-s}^{v d w}\right\rangle+\beta \Delta\left\langle V_{l-s}^{e l}\right\rangle
$$

Aplicações posteriores do método para a hidratação de diversas moléculas orgânicas implementaram uma constante $\gamma$ para adequar os valores de energia, ao considerar a cavitação causada pela molécula, corrigindo a equação com a área de superfície acessível ao solvente ( $\gamma \mathrm{SASA}$ - solvent-accessible surface area, Equação 5) (Carlson e J orgensen, 1995). Esta constante também pode ser adotada e variar de acordo com a hidrofobicidade do sítio receptor (Wang et al., 1999).

$$
\Delta G_{\text {lig }}=\alpha \Delta\left\langle V_{l-s}^{v d w}\right\rangle+\beta \Delta\left\langle V_{l-s}^{e l}\right\rangle+\gamma S A S A
$$

A aplicação do método de energia linear de interação para estimar a energia livre de interação entre a protease do HIV e três inibidores foi realizada no campo de força GROMOS modificado (Aqvist et al., 1994) e comparada ao método mais extenso FEP revelou valores muito próximos em acordo com dados experimentais (Hansson e Aqvist, 1995). Os valores de $\alpha$ e $\beta$ adotados para o cálculo de energia livre de ligação por LIE foram respectivamente 0,181 e 0,33, de acordo com a metodologia sugerida para ligantes neutros com 2 ou mais grupos $\mathrm{OH}$, caso do nelfinavir (Hansson et al., 1998; Aqvist et al., 2002). Estes parâmetros geraram valores de $\Delta \mathrm{G}$ similares aos da simulação de proteases complexadas com saquinavir (Aruksakunwong et al., 2006), mas um pouco inferiores aos medidos empiricamente para a protease selvagem complexada ao nelfinavir por calorimetria (Kozisek et al., 2007). Foram consideradas pontes de hidrogênio interações entre hidrogênio e átomos de O e N próximos 3,5 ou menos em um ângulo máximo de $120^{\circ}$. 


\subsection{Construção do vetor recombinante}

\subsubsection{Digestão e ligação dos fragmentos amplificados e do plasmídeo cultivado}

O plasmídeo pNL4-3 foi gentilmente doado pelo programa AIDS Research and Reference Reagent Program. Para obtenção de DNA para os procedimentos de digestão, ligação e amplificação, ele foi transformado e mantido em bactérias Escherichia coli DH5 alpha termocompetentes. Um volume de $150 \mu \mathrm{l}$ de bactérias foi pré-incubado com $1 \mu \mathrm{l}$ de plasmídeo ou $15 \mu \mathrm{l}$ de ligação por 30 minutos em gelo. Em seguida, as bactérias são colocadas em banho molhado a $42{ }^{\circ} \mathrm{C}$ por 1 minuto e novamente no gelo por 2 minutos. Após a incubação, $150 \mu \mathrm{l}$ de meio SOC foram adicionados e as bactérias foram agitadas a $37^{\circ} \mathrm{C}$ e $180 \mathrm{RPM}$ por 1 hora, e em seguida plaqueadas em meio LB-Amp com IPTG eX-gal.

A purificação do DNA bacteriano foi obtida de acordo com o protocolo do kit GeneJ ET ${ }^{\mathrm{Tm}}$ Plasmid Miniprep Fermentas (Fermentas International Inc., Burlington, Ontario, Canadá), usando $5 \mathrm{~mL}$ de E. coli DH5 alpha cultivadas em agitação a $28{ }^{\circ} \mathrm{C}$ por 12 horas. A purificação dos produtos de PCR foi realizada de acordo com o protocolo do kit NucleoSpin ${ }^{\circledR} 8$ Extract II (MACHEREY-NAGEL, Düren, Dürem, Alemanha). A digestão e ligação foram realizadas de acordo com o protocolo das enzimas NEB (New England Biolabs, Ipswich, Massachusetts, Estados Unidos), nas respectivas temperaturas ótimas durante 4 horas. A ligação foi feita com $100 \mathrm{ng}$ de vetor e uma concentração de insertos de 1:1, a $16{ }^{\circ} \mathrm{C}$ por 12 horas.

\subsubsection{PCR para amplificação dos fragmentos de pnl4-3}

Uma vez que a construção dos primers para criação dos sítios de restrição ao redor da protease limitou a similaridade dos mesmos com a sequência alvo, a ciclagem realizada usada foi um protocolo de touchdown, com um ciclo inicial de 94 ${ }^{\circ} \mathrm{C}$ por 2 minutos, 15 ciclos de $94{ }^{\circ} \mathrm{C}$ por 20 segundos, 20 ciclos de $62{ }^{\circ} \mathrm{C}$ por 30 segundos (diminuindo $1{ }^{\circ} \mathrm{C}$ a cada 2 ciclos) e $65^{\circ} \mathrm{C}$ por 9 minutos, e 20 ciclos de $94{ }^{\circ} \mathrm{C}$ por 20 segundos, $55^{\circ} \mathrm{C}$ por 30 segundos e $65^{\circ} \mathrm{C}$ por 9 minunots, com uma extensão final de $65{ }^{\circ} \mathrm{C}$ por 10 minutos. A mistura de reação e os primers encontram-se no ANEXO C. A ciclagem em touchdown foi escolhida por diminuir a formação de produtos inespecíficos, uma vez que os primeiros ciclos de amplificação são realizados em uma temperatura de anelamento mais estringente (62 $\left.{ }^{\circ} \mathrm{C}\right)$. A 
amplificação dos fragmentos esperados foi confirmada por gel de agarose $0,8 \%$, corado com brometo de etídeo.

\subsubsection{Sequenciamento do vetor}

As reações de sequenciamento foram realizadas pelo método de terminação de cadeia (método de Sanger), utilizando-se o dideoxinucleotideo dye terminator (Big Dye v.3.0 - Applied Biosystem, Foster City, Califórnia, Estados Unidos). Para a reação de sequenciamento são utilizados 50-150 ng do produto de PCR, 1ml de BDT, 3pl de tampão de sequenciamento, $3.2 \mathrm{pmol}$ do primer e $\mathrm{H}_{2} \mathrm{O}$ para $10 \mathrm{ml}$. O programa de ciclagem foi: $96{ }^{\circ} \mathrm{C}$ por 2 minutos, seguido de 35 ciclos de $96{ }^{\circ} \mathrm{C}$ por 30 segundos, 52 ${ }^{\circ} \mathrm{C}$ por 30 segundos e $60{ }^{\circ} \mathrm{C}$ por 4 minutos. Os primers estão descritos no ANEXO C. Os produtos obtidos na reação de sequenciamento foram precipitados em isopropanol e etanol para a remoção dideoxinucleotideos não incorporados. Seguindo as recomendações do fabricante, foi adicionado $40 \mu \mathrm{l}$ de isopropanol 65\% aos $10 \mu \mathrm{l}$ da reação de sequenciamento. A reação foi então incubada por 15 minutos em temperatura ambiente. Após este período a amostra foi centrifugada por 30 minutos a $3.000 \mathrm{x} \mathrm{g}$, e o sobrenadante foi retirado por inversão. Posteriormente, foram adicionados $150 \mathrm{\mu l}$ de etanol $60 \%$ e centrifugado por 10 minutos a 3.800x g. O sobrenadante foi retirado por inversão e o pellet mantido a $96{ }^{\circ} \mathrm{C}$ por 2 minutos, para eliminação do etanol residual. O DNA precipitado foi ressuspendido em $10 \mu \mathrm{l}$ de Formamida Hi-Di (Applied Biosystems) e denaturado por 3 minutos a $96{ }^{\circ} \mathrm{C}$, em seguida mantido em gelo por 5 minutos. Posteriormente as amostras foram analisadas no sequenciador automático ABI-PRISM 3100 (Applied Biosystems). 


\section{RESULTADOS}

\subsection{Integrases circulantes em São Paulo}

O sequenciamento e análise do gene da integrase (IN), entre as posições 4230 a 5093 do genoma do vírus HXB2, permitiu a detecção de novos recombinantes BF entre os pacientes recrutados pelo projeto VGDN. Das 157 integrases de pacientes VGDN, 128 foram classificadas como pertencentes ao subtipo B, 17 ao subtipo F, 1 ao subtipo $\mathrm{C}$ e 11 recombinantes $\mathrm{BF}$. Ao total, 31 vírus $\mathrm{BF}$ foram detectados por possuírem regiões genômicas discordantes - 8 integrases F e 23 integrases B em vírus BF - e 11 portadores de integrases recombinantes. Destes, 8 pacientes não eram reconhecidos como recombinantes antes do sequenciamento desta região (Tabela 4) e apresentaram uma integrase de subtipo discordante dos demais fragmentos, demonstrando a potencial subestimativa de recombinantes conhecidos com base no sequenciamento comum de pequenas regiões.

Tabela 4 - Perfil dos fragmentos dos novos recombinantes detectados devido à integrase de subtipo discordante.

\begin{tabular}{ccccc}
\hline Paciente & gag & pro-pol & integrase & env \\
\hline 0534 & B & B & F & B \\
0634 & B & B & F & B \\
0518 & - & B & F & B \\
1413 & - & B & F & B \\
1094 & B & B & F & B \\
1027 & F & - & B & F \\
1023 & - & - & B & F \\
1038 & - & - & B & F \\
\hline
\end{tabular}

Pacientes numerados de acordo com o código VGDN.

Fonte: Iamarino (2012).

Entre as integrases recombinantes, 4 das 11 amostras apresentaram regiões de incerteza e pontos de quebra concordantes preditos entre a posição 4900 e inéditos em CRFs descritas até o momento no continente (conforme descrito em ANEXO D, artigo 1 [Iamarino et al., 2012]). Tal característica permitiria a interpretação de que se trata de uma mesma forma recombinante, de acordo com métodos de classificação tradicionais, baseados em pontos de quebra concordantes entre recombinantes dos mesmos subtipos. Para testar esta hipótese, o trecho de 500 bases do subtipo B comum a todas foi utilizado na construção de árvores filogenéticas para a 
reconstrução de monofilia. Em um set de 5000 árvores geradas em duas corridas independentes de 20 milhões de passos, o estado "recombinante" foi reconstruído como um evento que surgiu independentemente, e em todos os casos os ramos pertencentes a integrases recombinantes foram agrupados separadamente (Figura 17). A mesma interpretação é apontada pela análise de ancestralidade das integrases $\mathrm{B}$ e $\mathrm{F}$ puras de vírus recombinantes encontradas na reconstrução por máxima verossimilhança, com poucos grupos distintos formados exclusivamente por sequências de recombinantes (Figura 18).

Figura 17 - Árvore filogenética das primeiras 500 bases do subtipo B de integrases

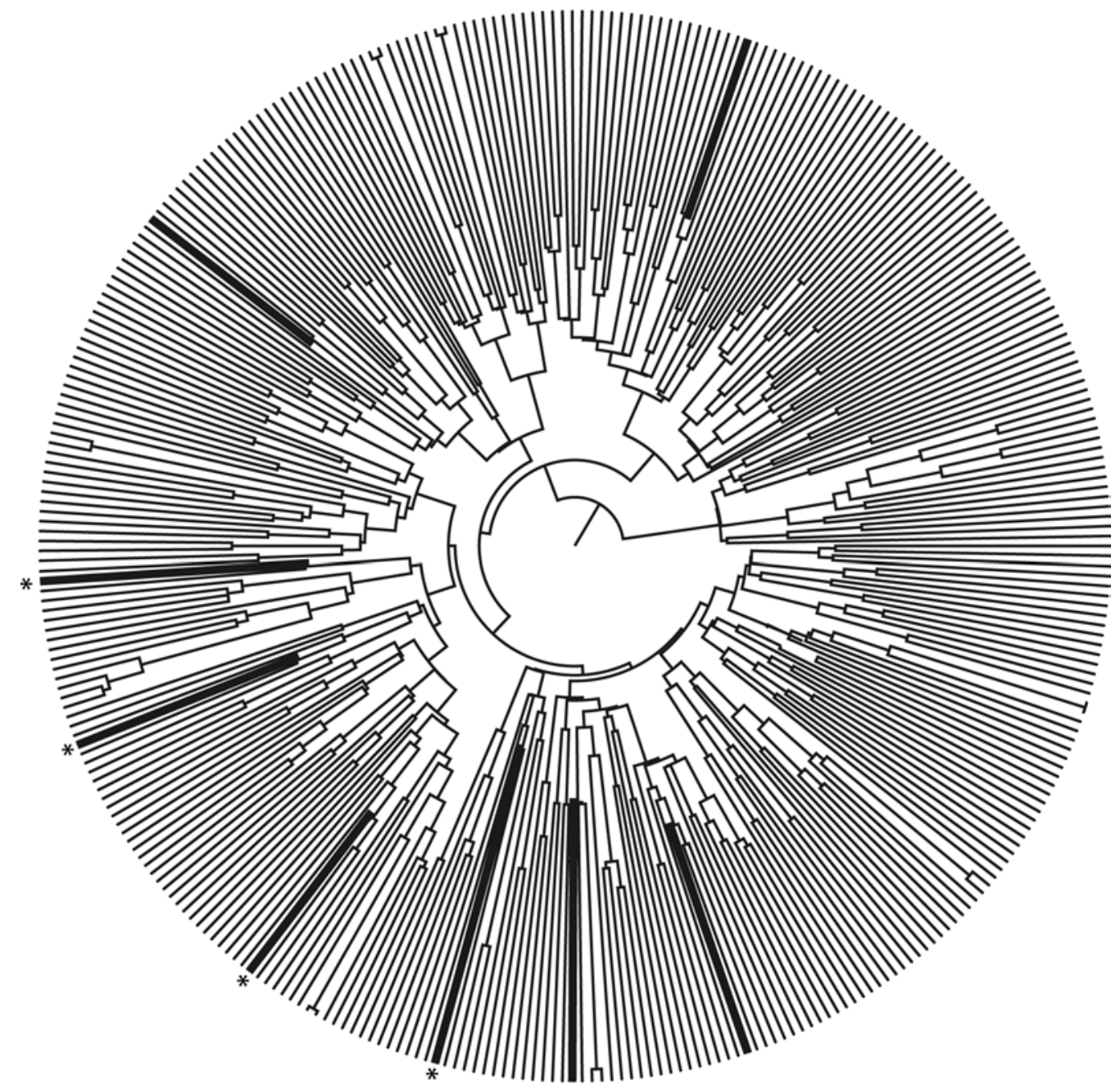

O cladograma resume a árvore de máxima credibilidade de clado (MCC) do segmento de 500 bases de subtipo B compartilhado por integrases puras e recombinantes BF. Os clados espessos destacam a reconstrução do estado "recombinante" usando a reconstrução de caracteres discretos do programa BEAST (conforme descrito em ANEXO D, artigo 1 [Iamarino et al., 2012]), e sequências recombinantes com ponto de quebra em comum estão marcadas com asteriscos.

Fonte: Iamarino et al. (2012). 
Figura 18 - Reconstrução filogenética por máxima verossimilhança de integrases do Brasil

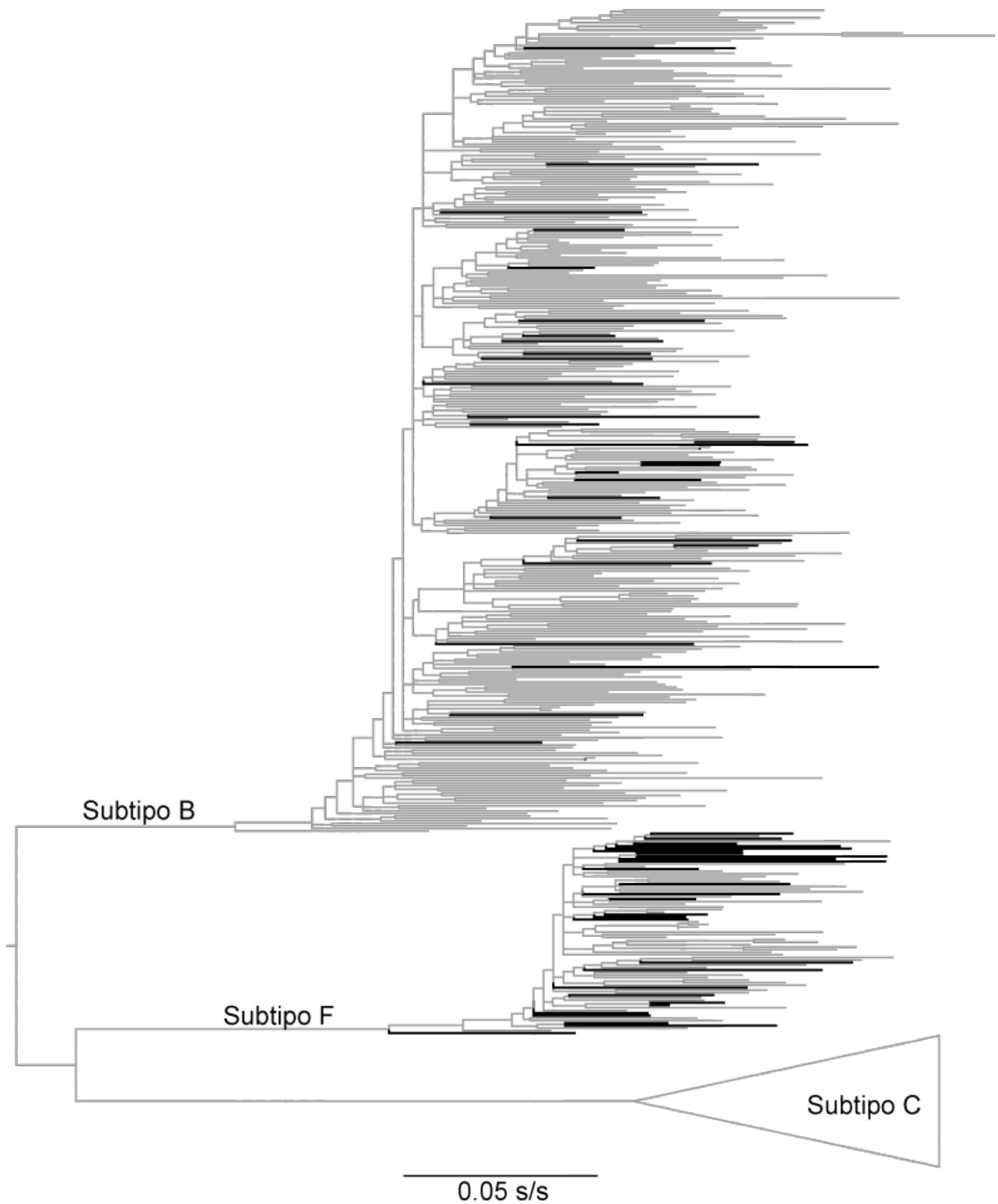

Integrases puras de 145 pacientes VGDN e 314 obtidas de outros estudos usando o programa GARLI (conforme descrito em ANEXO D, artigo 1[Iamarino et al., 2012]). Ramos espessos representam sequências de vírus recombinantes de acordo com outras regiões genômicas. Fonte: Iamarino et al. (2012).

A estimativa de seleção entre as integrases revelou uma quantidade significativamente maior de sítios positivamente selecionados em sequencias do subtipo B (Figura 1 do ANEXO D [Iamarino et al., 2012]), cenário condizente com a 
entrada mais recente do subtipo F no país (Bello et al., 2006; 2007). Embora quase 86\% dos pacientes estivessem sob HAART, dado o período de amostragem do projeto anterior à disponibilidade de inibidores de integrase, nenhum deles fora medicado com INIs. Conforme o esperado (Passaes et al., 2009; Arruda et al., 2010), mutações associadas à resistência a raltegravir e elvitegravir foram encontradas, mas em nenhum dos casos tratava-se de uma mutação de resistência primária (66I, 92Q, 140A/ S, 143R/ C, 147G, 148H/R/K, e 155H).

\subsection{Epidemia de recombinantes na Argentina}

Da análise de 133 sequências do gene pol (cobrindo a protease e o início da polimerase) do HIV-1 de pacientes da Argentina amostrados em 1999 e 2000, foi possível analisar a mudança de predominância entre grupos de risco ocorrida pouco antes do ano 2000. As amostras formaram dois grupos distintos, um com 83 de sequências do subtipo $\mathrm{B}$ e outro com 23 recombinantes $\mathrm{BF}$ similares à CRF12_BF que compartilhavam o mesmo ponto de quebra, com uma protease do subtipo $\mathrm{F}$ e polimerase do subtipo $B$. As demais sequências também pertencem a recombinantes BF, mas estes não formaram grupos grandes o suficiente para possibilitar a análise filodinâmica. 
Figura 19 - Reconstrução demográfica de amostras de HIV do subtipo B e recombinantes BF (CRF12-like) argentinas adaptada de ANEXO D (artigo 2, Figura 1)

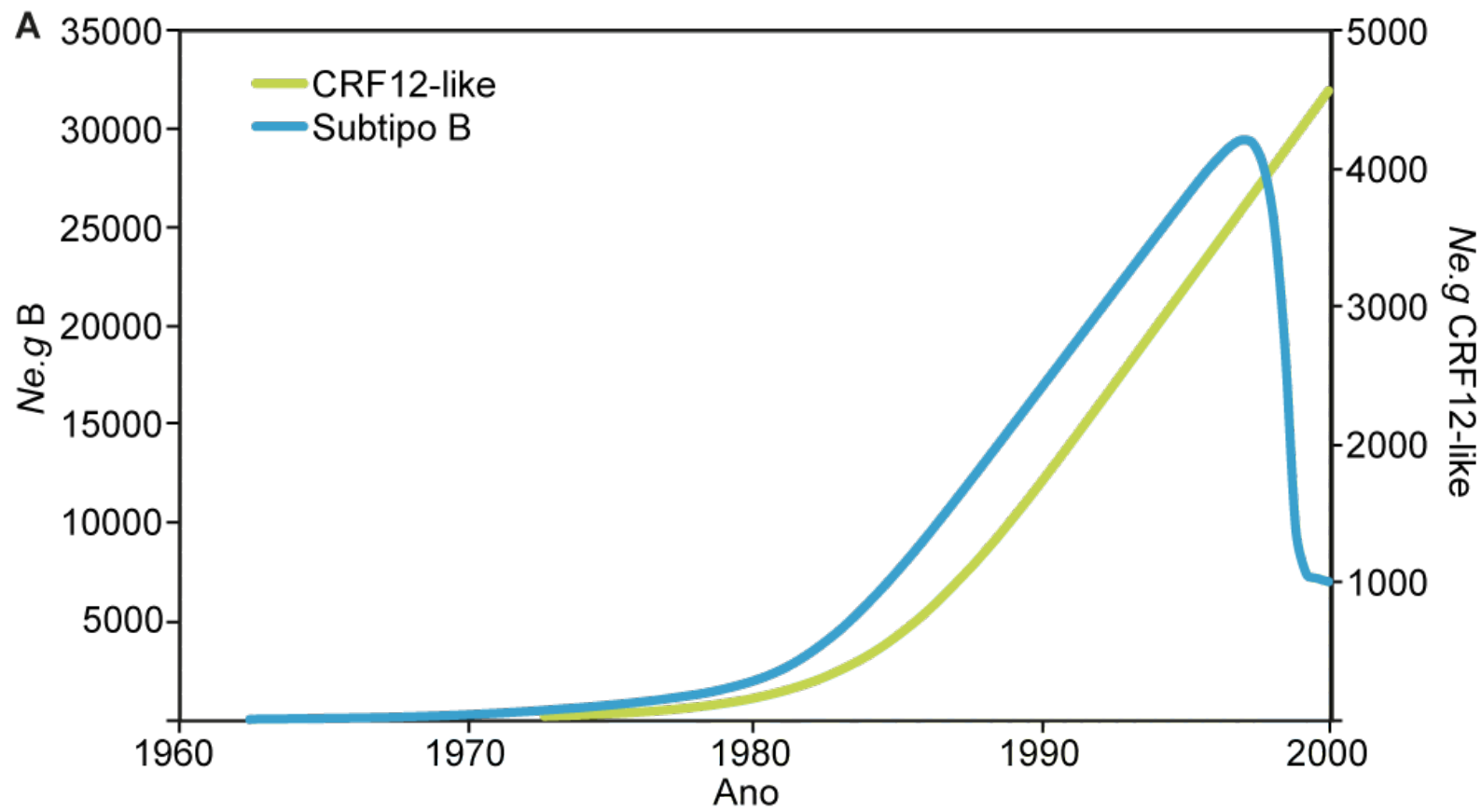

B

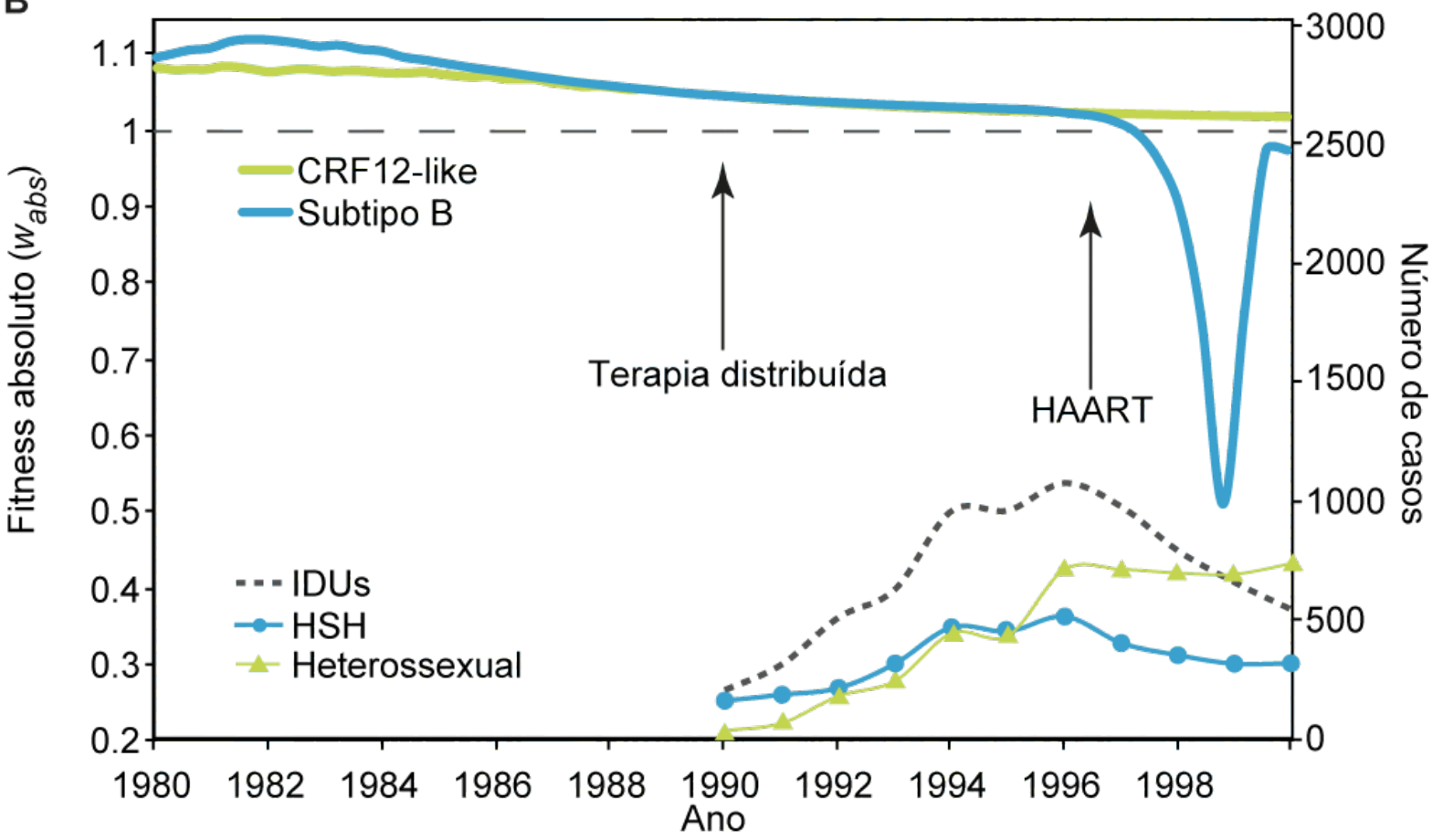

O crescimento de cada grupo estimado pelo tamanho efetivo da população (Ne.g estimado pelo programa BEAST) está representado em $\mathrm{A}$. O fitness absoluto $\left(\mathrm{w}_{\mathrm{abs}}\right)$ calculado pela comparação do crescimento viral de um ano frente ao ano anterior representado em $B$ relaciona esta tendência com a implementação da terapia antirretroviral grátis em 1990 e da HAART em 1996, e é corroborado por dados epidemiológicos (Boletín ..., 2002) (apresentados na região inferior direita do gráfico). Fonte: Iamarino et al. (2012, ANEXO D, artigo 2). 
A partir da inferência da dinâmica evolutiva das linhagens B e recombinantes BF (CRF12-like), foi possível observar que o crescimento dos recombinantes foi mais bem descrito pelo modelo exponencial, enquanto a dinâmica do subtipo $\mathrm{B}$ foi complexa demais para ser descrita por um modelo simples. Uma análise mais cuidadosa do tamanho de população do subtipo B demonstrou uma grande queda na população efetiva (Ne.g), que aproxima o número de novas infecções deste subtipo durante a segunda metade da década de noventa. O mesmo efeito não foi observado nas populações recombinante (Figura 19).

O declínio do subtipo B ressaltado pela medida de fitness absoluto (Wabs) é concordante com os dados epidêmicos da Argentina (Figura 19). A epidemia argentina apresenta uma segregação entre modo de transmissão e subtipo durante o período amostrado de maneira similar à África do Sul, onde o subtipo B foi associado à transmissão entre HSHs e o subtipo C à transmissão heterossexual (van Harmelen et al., 1997). Enquanto HSHs soropositivos eram portadores do subtipo B e predominantes durante o início da epidemia, os heterossexuais, grupo de risco em crescimento durante o período, (Boletín ..., 2002) foram infectados principalmente por recombinantes BF (Avila et al., 2002). E a dinâmica observada de diminuição do crescimento do subtipo B e crescimento sustentado de CRF12-like é compatível com este cenário.

\subsection{Dinâmica molecular de proteases B e F resistentes}

As proteases B e F foram modeladas e simuladas, permitindo a comparação entre a influência dos polimorfismos de cada subtipo nas mutações de resistência primária. A flutuação de carbono a (RMSF, Root Mean Square Fluctuation) da protease controle do subtipo $\mathrm{F}$ (CtrlF) foi menor do que a registrada para a protease $\mathrm{B}$ selvagem (CtrlB), conforme demonstrado na Figura 20. Além de registrar uma flutuação menor, mesmo sem mutações de resistência primária, esta protease registrou uma afinidade muito menor pelo inibidor nelfinavir (Tabela 5). Tal diferença também pode ser vista pelo número menor de pontes de hidrogênio formadas entre o resíduo catalítico Asp25 e o inibidor (Tabela 5) e pela RMSF dos átomos das regiões P1, P2 e P2' do nelfinavir (ANEXO D, artigo 3, Figuras 2 e 3). 
Tabela 5 - Medidas de interação colhidas após 4 ns de simulação.

\begin{tabular}{cc|rc|rrr|r}
\hline & \multicolumn{4}{c}{ Distância do flap } & \multicolumn{2}{c}{ Pontes de hidrogênio } & \multicolumn{1}{c}{ Ligação } \\
\hline Mutações & \multicolumn{3}{c}{ Asp25 - Ile50 } & Asp25' - Ile50' & \multicolumn{1}{c}{ Asp25 } & \multicolumn{1}{c}{ Asp25' } & \multicolumn{1}{c}{$\Delta \mathbf{G ~ k J / m o l ~}$} \\
\hline & $\mathbf{C t r I B}$ & $1,31 \pm 0,05$ & $1,74 \pm 0,09$ & $1,93 \pm 0,49$ & $0,06 \pm 0,24$ & $-44,02 \pm 8,67$ \\
& CtrIF & $1,35 \pm 0,08$ & $1,71 \pm 0,05$ & $1 \pm 0,14$ & $0,12 \pm 0,33$ & $-27,04 \pm 7,87$ \\
\hline G48V, & $\mathbf{1 1 2 0}$ & $1,55 \pm 0,01$ & $1,82 \pm 0,06$ & $1,61 \pm 0,61$ & $0 \pm 0,07$ & $-30,77 \pm 9,7$ \\
I54T & $\mathbf{1 2 2 7}$ & $1,35 \pm 0,05$ & $1,74 \pm 0,05$ & $1,09 \pm 0,39$ & $0,22 \pm 0,41$ & $-29,66 \pm 8,47$ \\
e V82A & $\mathbf{0 4 5 0}$ & $1,3 \pm 0,05$ & $1,8 \pm 0,09$ & $1,73 \pm 0,51$ & $0,2 \pm 0,41$ & $-32,08 \pm 7,53$ \\
\hline & $\mathbf{1 2 1 8}$ & $1,44 \pm 0,06$ & $1,72 \pm 0,04$ & $0,01 \pm 0,08$ & $1 \pm 0,03$ & $-32,55 \pm 7,27$ \\
M46L e & $\mathbf{0 0 8 7}$ & $1,32 \pm 0,05$ & $1,77 \pm 0,06$ & $1 \pm 0,14$ & $0,84 \pm 0,36$ & $-20,09 \pm 8,73$ \\
V82A & $\mathbf{0 7 3 2}$ & $1,63 \pm 0,11$ & $1,78 \pm 0,05$ & $1,17 \pm 0,43$ & $0,14 \pm 0,35$ & $-22,85 \pm 7,19$ \\
\hline & $\mathbf{0 4 4 9}$ & $1,46 \pm 0,18$ & $1,72 \pm 0,05$ & $1,64 \pm 0,53$ & $0,88 \pm 0,57$ & $-39,34 \pm 8,36$ \\
I54V e & $\mathbf{0 8 0 5}$ & $1,45 \pm 0,14$ & $1,59 \pm 0,1$ & $1,13 \pm 0,38$ & $0,04 \pm 0,2$ & $-34,3 \pm 9,09$ \\
L90M & $\mathbf{0 0 6 3}$ & $1,28 \pm 0,04$ & $1,73 \pm 0,1$ & $1,92 \pm 0,32$ & $0,04 \pm 0,19$ & $-31,64 \pm 6,87$ \\
\hline
\end{tabular}

As proteases estão agrupadas de acordo com as mutações primárias. Proteases F estão em cinza. A distância entre do flap corresponde ao RMSF em nm da distância entre o carbono $\alpha$ do resíduo da ponta do flap (Ile50) ao carbono $\beta$ do resíduo catalítico (Asp25) da cadeia correspondente. Ligação representa energia livre de ligação estimada entre nelfinavir e protease.

Fonte: Iamarino et al. (2012, ANEXO D, artigo 3).

Da interação entre a protease com a mutação de resistência G48V e o inibidor saquinavir foram inferidas energias de ligação de $-37.3 \mathrm{kcal} / \mathrm{mol}$ para a protease monoprotonada em Asp25 (Aruksakunwong et al., 2006). Para o nelfinavir ligado à protease selvagem e com as mutações D30N, D30N/A71V, D30N/L90M e D30N/N88D os valores de $\Delta \mathrm{G}$ obtidos por calorimetria foram respectivamente $-54,4 \pm 0,2 \mathrm{~kJ} / \mathrm{mol},-48,6 \pm 0,4 \mathrm{~kJ} / \mathrm{mol},-43,1 \pm 0,4 \mathrm{~kJ} / \mathrm{mol},-41 \pm 0,3 \mathrm{~kJ} / \mathrm{mol}$ e $-38,9 \pm 0,4 \mathrm{~kJ} / \mathrm{mol}$ (Kozisek et al., 2007), todos valores são próximos aos obtidos através da dinâmica molecular aqui empregada, que podem ser considerados sem a necessidade de um fator de correção $\gamma$ (Tabela 5). 
Figura 20 - Flutuação do carbono $\alpha$ de cada resíduo (RMSF) em relação ao controle B após 4 nanosegundos de simulação.
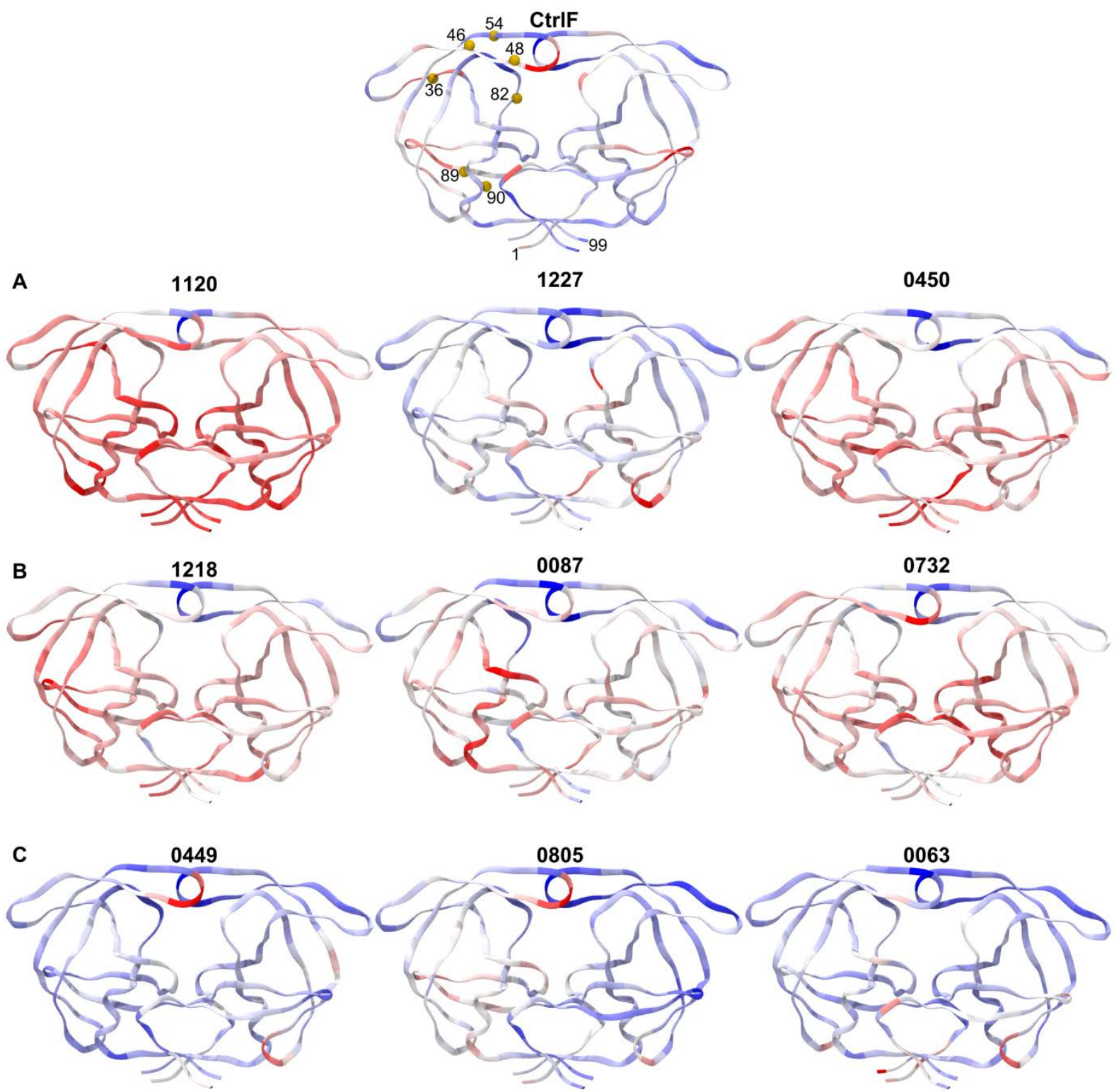

Os resíduos foram coloridos de acordo com a diferença de RMSF de carbono $\alpha$ em relação ao resíduo correspondente na protease controle do subtipo B, de um mínimo de -0,1 nm (azul escuro) a um máximo de $0,2 \mathrm{~nm}$ (em vermelho). Flutuações sem diferença foram coloridas em branco. As posições dos resíduos que podem sofrer as mutações de resistência consideradas estão marcados em amarelo, e as proteases foram agrupadas de acordo com o grupo de mutações apresentadas: (A) Proteases com G48V, I54T/V e V82A. (B) Proteases com M46I/L e V82A. (C) Proteases com I54V e L90M.

Fonte: Iamarino et al. (2012, ANEXO D, artigo 2).

Entre as proteases agrupadas pelas mutações G48V, I54T/V e V82A (0450, 1227 e 1120), foi possível observar o efeito das mutações G48V e I54T em comprometer a flexibilidade do flap (Dirauf et al., 2010) (Figura 19). A protease B 1120, que não possui a mutação G48V, apresentou a maior RMSF nesta região (Figura 19) e 
distância entre os flaps (representados pelo resíduo Ile50) e o sítio ativo (Tabela 5). Esta protease também apresentou os maiores efeitos da mutação V82A, conhecida por causar uma assimetria entre os subsítios S1 e S1' (Clemente et al., 2004a), o que permitiu diferentes conformações das regiões correspondentes P1 e P1' (ANEXO D, artigo 3, Figura 3). Já a protease F 0450, mesmo apresentando uma flutuação dos átomos da região S1 e S1' e de nelfinavir similar à de CtrlB (ANEXO D, artigo 3, Figura Suplementar 1), manteve a menor afinidade pelo inibidor de acordo com a energia livre de ligação (Tabela 5).

Para a comparação das mutações M46I/L e V82A as proteases F 0087 e 0732 foram comparadas à protease B 1218. A mutação M46L é conhecida por alterar a conformação dos flaps e agir de forma sinérgica com V82A diminuindo a afinidade por PIs (Clemente et al., 2004b). Efeito este que foi significativamente mais acentuado nas proteases $\mathrm{F}$, como foi observado pela flutuação das regiões S1/ S1' e S2/S2' (ANEXO D, artigo 3, Figura Suplementar 1), regiões P1 e P2 de nelfinavir (ANEXO D, artigo 3, Figura 3) e, principalmente, pela energia livre de ligação (Tabela $5)$.

As duas proteases B (0449 e 0805) agrupadas na comparação com a protease F 0063 do efeito das mutações I54V e L90M apresentaram uma maior flutuação dos flaps (Figura 19) e da região P1 do nelfinavir (ANEXO D, artigo 3, Figura 2). Por outro lado, a protease F 0063 apresentou a menor afinidade pelo nelfinavir (Tabela 5), mesmo com distância de flaps e número de pontes de hidrogênio mais similares ao de CtrlB (Tabela 5).

\subsection{Construção de um clone infeccioso de HIV-1 recombinante.}

Dado os resultados da dinâmica molecular, indicadores de uma afinidade diferente para proteases $F$ portadoras de mutações de resistência primárias similares às do subtipo $\mathrm{B}$, o próximo passo para o estudo do efeito destas mutações foi o ensaio in vitro do desempenho de uma protease F em um genoma do subtipo B. Para tal, o primeiro passo foi a construção de um "esqueleto" que permitisse a rápida substituição da região genômica da protease com base em um vetor montado sobre o clone infeccioso pNL4-3 (Adachi et al., 1986). O pNL4-3 é uma construção feita a partir de dois isolados de HIV inseridos em um plasmídeo pUC18 muito eficiente para transfecção de diversas linhagens celulares. 
O vetor consiste no vírus do subtipo B com a sua protease flanqueada pelos sítios de digestão NotI e BstBI que, ao ser digerido, libera o espaço para que proteases do subtipo F já modeladas sejam ligadas. Para a inserção de novas proteases, seria necessária a criação de dois sítios de restrição únicos ao redor do gene da protease, que precisassem do menor número de modificações de nucleotídeos possível. Os dois candidatos foram a criação do sítio NotI no início do gene e BstBI ao final (Figura 21).

Para a introdução destes sítios, foram desenhados primers que inserem mutações silenciosas na região de interesse, criando regiões de reconhecimento pelas respectivas enzimas de restrição, sem que a composição de aminoácidos da protease seja alterada. Os primers do sítio NotI são capazes de reconhecer sequências do subtipo B e F introduzindo apenas mutações silenciosas. Por outro lado, no sítio BstBI, o primeiro aminoácido da polimerase do subtipo B, uma prolina é substituída por uma arginina, polimorfismo comum na polimerase do subtipo $F$ que, espera-se, não cause efeitos na atividade da transcriptase reversa. Este efeito é reproduzido no vírus controle, o pNL4-3 com sua protease recolocada usando os mesmos sítios de restrição, desta forma portando as mesmas mutações silenciosas e o mesmo resíduo de arginina em sua transcriptase reversa. 
Figura 21 - Mapa do vetor pNL4-3 modificado buscado

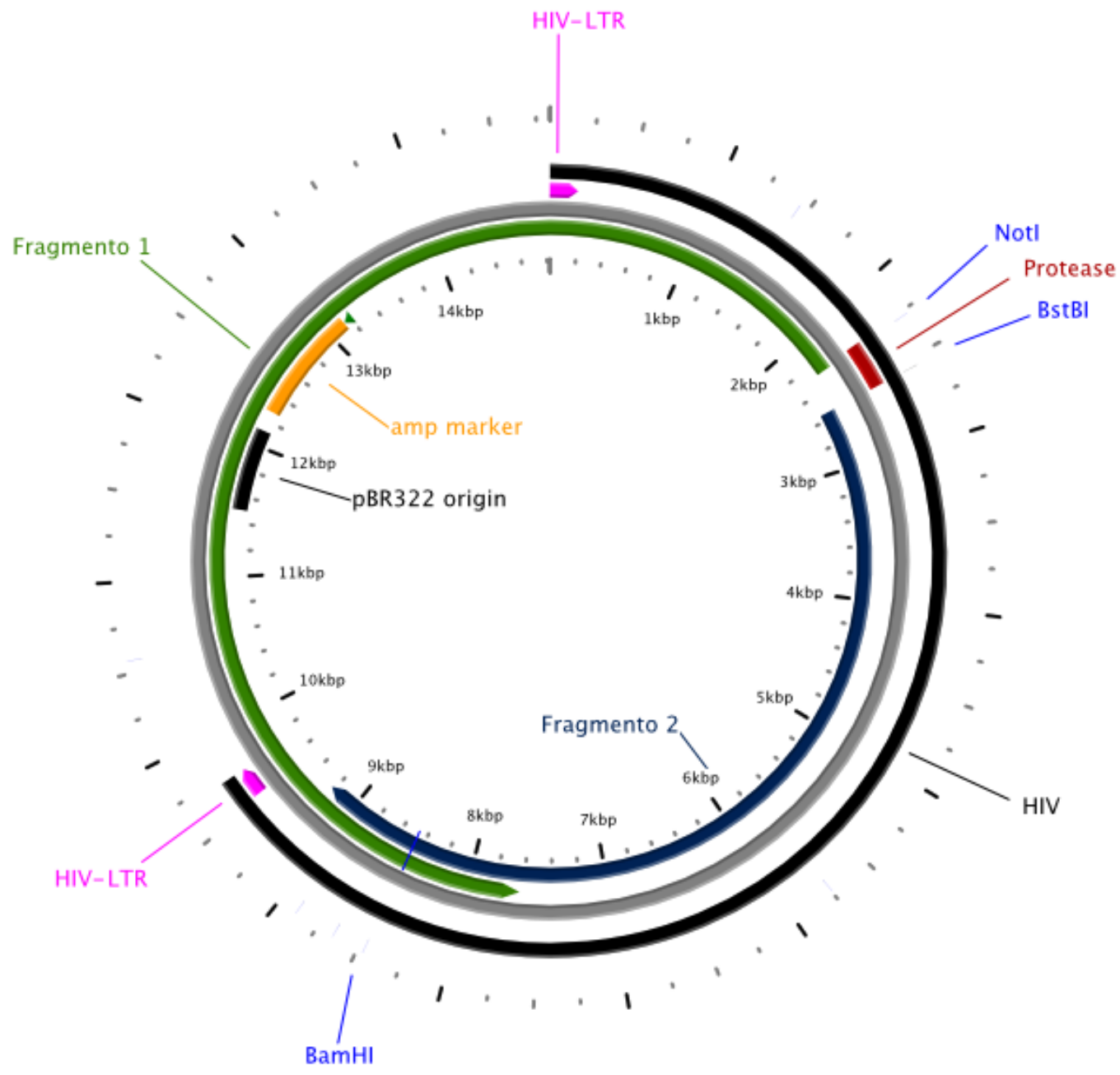

O genoma do vírus NL4-3 marca a primeira base. Ao redor da protease estão os sítios de digestão NotI e BstBI, em azul. Aos 8466 pares de base, está o sítio de digestão por BamHI. Fonte: Iamarino (2012).

\subsubsection{PCR longo com os primers NotI e BstBI.}

A primeira estratégia para a construção do vetor foi a amplificação do fragmento de 300pb da protease com primers NotI 5' e BstBI 3' e um PCR longo com os primers NotI 3' e BstBI 5'. Para a amplificação da protease foram utilizadas duas fontes de DNA, o plasmídeo pNL4-3 e o vírus padrão para testes com o subtipo F BZ126, ambos fornecidos pelo Programa NIH AIDS Research \& Reference Reagent. Ambas as proteases foram amplificadas, embora a reação com pNL4-3 como substrato tenha originado produtos inespecíficos: 
Figura 22 - Proteases amplificadas.

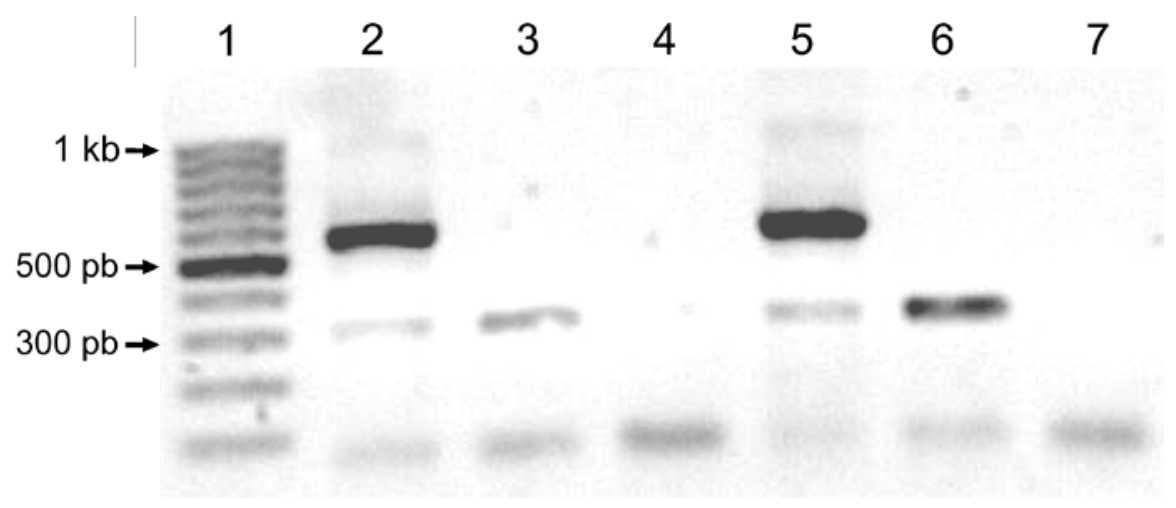

No poço 1, o marcador de peso molecular. Nos poços 4 e 7, o controle sem cDNA (branco). Nos poços 2 e 5 está a protease B e, nos poços 3 e 6, a protease F. Foram testadas duas concentrações de $\mathrm{MgCl}_{2}, 1 \mathrm{mM}$ (poços 2 a 4) e $2 \mathrm{mM}$ (poços 5 a 7), para diferentes especificidades de reação. Ambas as proteases foram mais bem amplificadas, mas a reação mais específica ocorreu com $2 \mathrm{mM}$ de $\mathrm{MgCl}_{2}$.

Fonte: Iamarino (2012).

Conforme esperado dada a similaridade de nucleotídeos do primer, a amplificação da protease $\mathrm{F}$ foi obtida com mais facilidade (Figura 22). Como os primers precisam criar os sítios NotI e BstBI introduzindo mutações silenciosas, há a possibilidade de amplificações não específicas como as observadas para a protease B, que precisou ser recortada do gel e purificada para os procedimentos posteriores.

O PCR longo não foi bem sucedido em nenhuma das várias condições testadas, produzindo apenas bandas inespecíficas com tamanho menor do que o esperado, apesar do uso de uma enzima específica para reações longas capaz de amplificar fragmentos de cerca de $10 \mathrm{~kb}$ em experimentos prévios do laboratório e recomendada para amplificação de grandes regiões genômicas do HIV-1 (Nadai et al., 2008). Tal falha provavelmente ocorreu por conta do tamanho da amplificação, mais de $14 \mathrm{~kb}$, e pela ligação incompleta dos primers, com cerca de $80 \%$ de identidade com o substrato. O longo período de extensão necessário, de 12 minutos, também deve ter contribuído para que ocorra a re-ligação das fitas de DNA e consequente terminação da formação da nova cadeia.

\subsubsection{Utilização de dois PCRs intermediários.}

Como alternativa à estratégia anterior, foram desenhados primers mais internos para amplificação de dois fragmentos intermediários, 1 e 2 (em azul e verde, respectivamente, na Figura 21), que são digeridos e ligados através do sítio BamHI 
para formação do vetor sem a protease. O fragmento 1 é formado pelos primers NotI 3' e F15', que abrangem do início da protease até o nucleotídeo 7631 do NL4-3, com o tamanho de 9446 pb e contendo um sítio de restrição por BamHI na posição 837 (Figura 21). O fragmento 2 é formado pelos primers BstBI 5' e F1 3', compondo um fragmento de 6679 pb do final da protease até o nucleotídeo 9228 do vírus, com um sítio de restrição BamHI na posição 5916 (Figura 21).

A partir dos fragmentos amplificados, a protease $F$ (que apresentou melhor rendimento), fragmento 1 e fragmento 2 , foram realizadas as etapas de digestão e ligação. Todos os fragmentos foram purificados através da extração do DNA cortado do gel de agarose, mantendo apenas a banda de tamanho esperado e descartando fragmentos inespecíficos (Figura 23).

Figura 23 - Fragmentos amplificados e purificados antes de serem submetidos à digestão

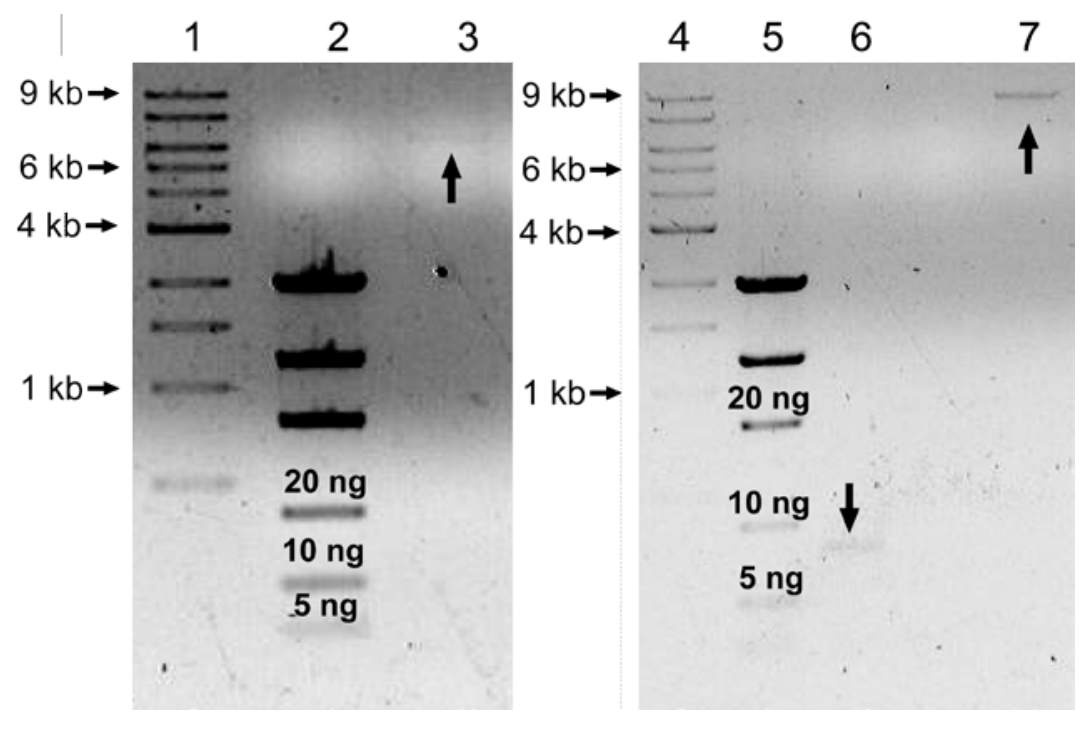

Nos poços 1 e 4, o marcador de peso molecular. Nos poços 2 e 5, o marcador de quantidade de DNA. Nos demais, Fragmento 1 (poço 3), Fragmento 2 (poço 7) e protease (poço 6). Fonte: Iamarino (2012).

Os fragmentos 1 e 2 foram então submetidos à dupla digestão com as enzimas correspondentes às extremidades de interesse: Protease F digerida com NotI e BstBI; Fragmento 1 digerido com NotI e BamHI; e fragmento 2 com BstBI e BamHI. Todas as digestões resultaram em fragmentos do tamanho esperado (Figuras 24 e 25). 
Figura 24 - Digestão do fragmento 1

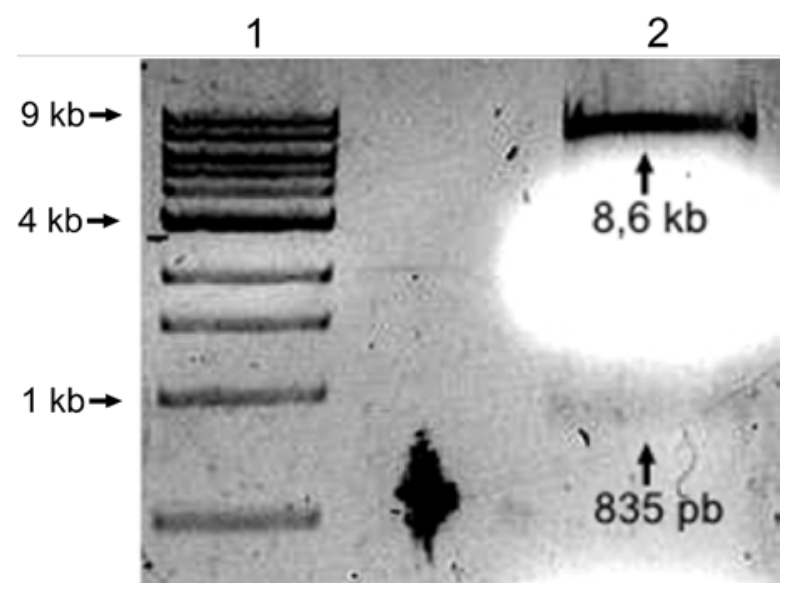

No poço 1, o marcador de peso molecular. A região amplificada por PCR contém $\sim 9,45 \mathrm{~kb}$, das quais 8611 bases (poço 2) correspondem à região de interesse para ligação e foram recortadas do gel e purificadas.

Fonte: Iamarino (2012).

Figura 25 - Digestão do fragmento 2

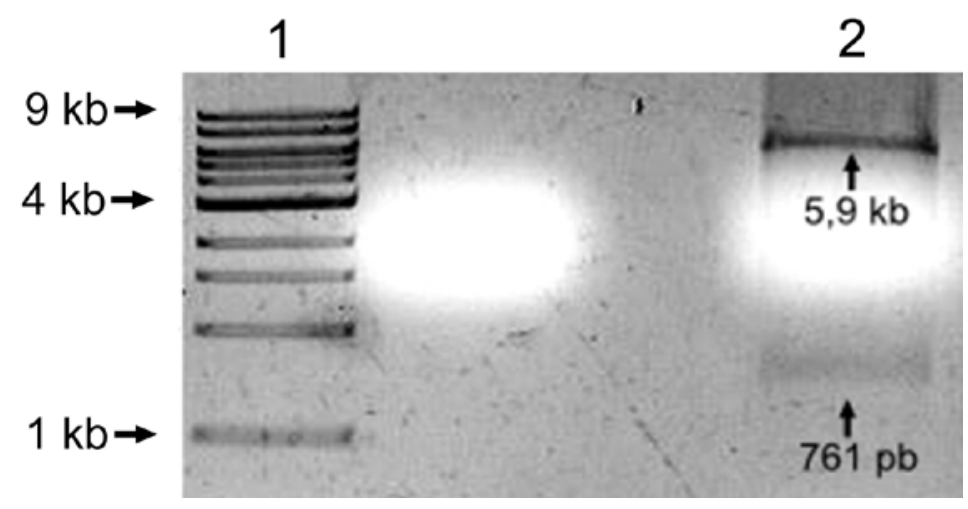

No poço 1, o marcador de peso molecular. O produto de PCR de $\sim 6,6 \mathrm{~kb}$ foi digerido, produzindo dois fragmentos (poço 2), o fragmento maior de 5,9 kb que foi utilizado na ligação depois de purificado e um fragmento de $761 \mathrm{pb}$. Fonte: Iamarino (2012).

Os três fragmentos resultantes da digestão foram ligados e transformados em bactérias E. coli competentes. Porém, não houve colônias transformadas. Em paralelo à construção do vetor pNL4-3 modificado utilizando diretamente os fragmentos amplificados por PCR, foi adotada a estratégia de ligar os produtos de PCR em um vetor intermediário. Neste experimento, os produtos de PCR foram purificados e ligados ao vetor pGEM-T, e em seguida transformados. A extração do plasmídeo e posterior linearização do mesmo com a enzima PstI revelou que os fragmentos 1 e 2 não foram inseridos e transformados com sucesso, uma vez que o vetor carregando estas sequências deveria ter um tamanho maior do que $10 \mathrm{~kb}$. Além 
disso, á a complicação de que no caso do fragmento 1 ocorre mais de um sítio de origem no vetor.

4.4.3 PCRs curtos com os primers NotI e BstBI.

Figura 26 - Mapa do vetor pNL4-3 usado na estratégia de PCRs curtos

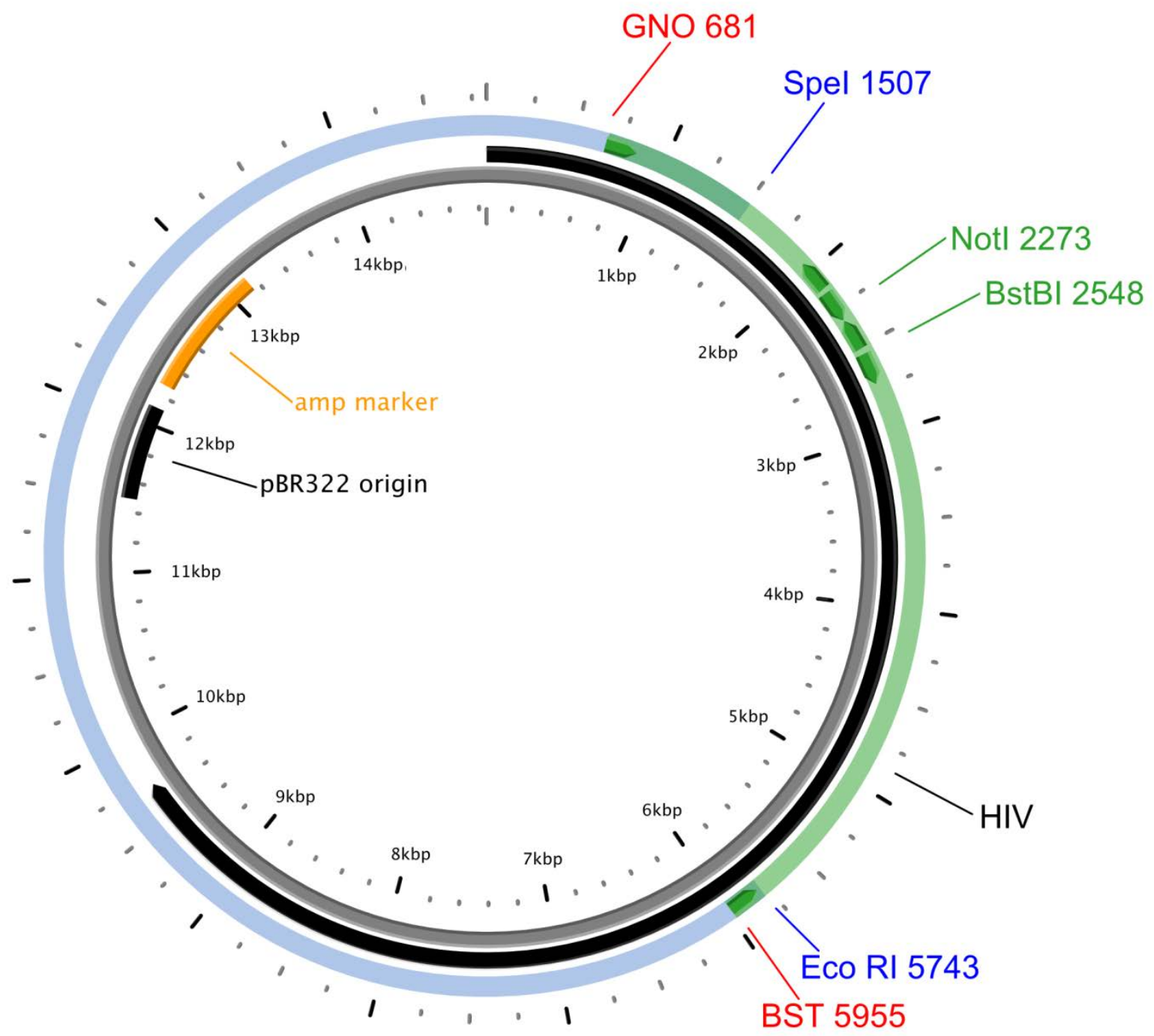

O genoma do vírus NL4-3 marca a primeira base. Ao redor da protease estão em verde os sítios de digestão NotI e BstBI a serem amplificados e inseridos. Em vermelho estão os nomes e posição dos primers, e em azul o nome e posição dos sítios únicos de digestão utilizados para amplificar e ligar os fragmentos.

Fonte: Iamarino (2012).

Visando aumentar o rendimento obtido com os ciclos de PCR e diminuir a região a ser amplificada do plasmídeo, e reduzir a chance de inserção de erros na construção, foram desenhados novos primers para o uso de fragmentos menores e a 
redução de passos intermediários. Seguindo esta estratégia, ao invés de amplificar toda a construção, os primers geram produtos iniciados pouco antes de sítios únicos de restrição (ver Figura 26) ao redor da protease. Assim, os produtos NotI-GNO, com 1572 bp, que contém o sítio de restrição Spel (Figuras 26 e 27); NotI-BstBI que contém a protease e ambos os sítios nas pontas, com 300 bp (Figuras 26 e 28); e BstBI-BST com 3405 bp, que contém o sítio EcoRI (Figura 27) foram amplificados. Três fragmentos, que foram ligados a um fragmento de 10588 bp, correspondente ao plasmídeo pNL4-3 selvagem digerido com as enzimas SpeI e EcoRI (Figura 29).

Figura 27 - Fragmentos amplificados com PCRs curtos

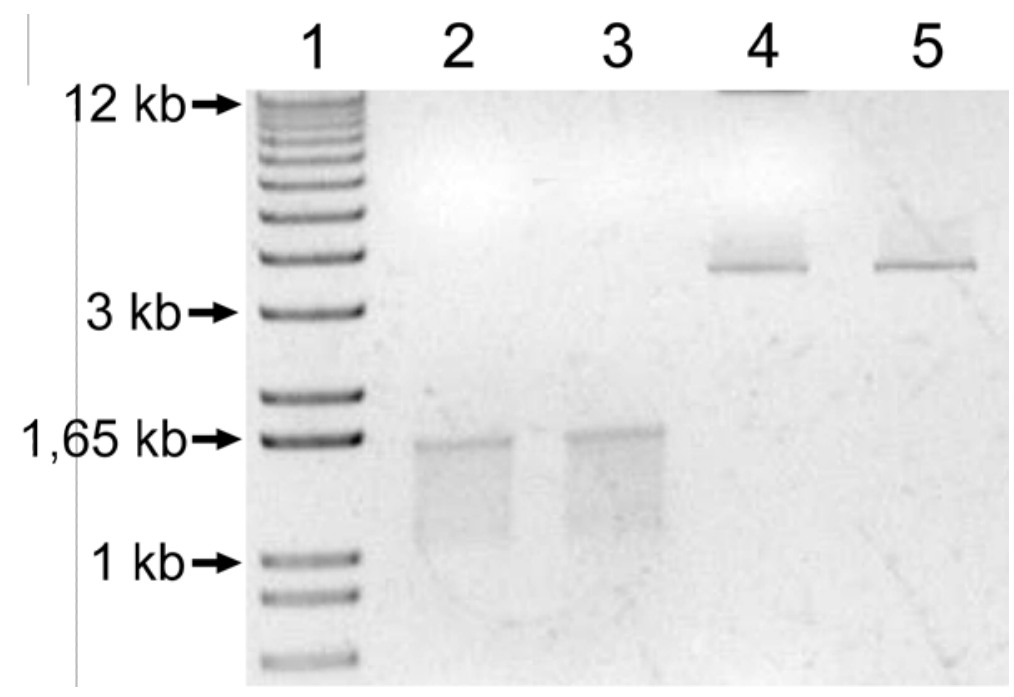

No poço 1, o marcador de peso molecular. Fragmentos NotI-GNO (1572 bp) nos poços 2 e 3, e BstBI-BST (3405 bp) nos poços 4 e 5.

Fonte: Iamarino (2012).

Figura 28 - Protease amplificada para nova estratégia.

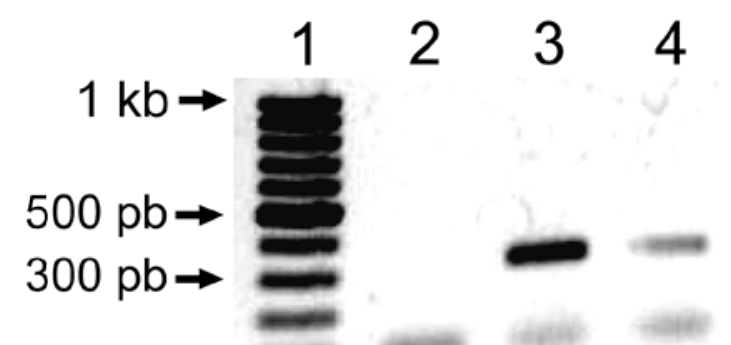

No poço 1, o marcador de peso molecular. No poço 2, reação sem produto formado. Nos poços 3 e 4 , o fragmento NotI- BstBI (protease, $300 \mathrm{bp}$ ) amplificado. Fonte: Iamarino (2012). 
Figura 29 - Vetor nNL4-3 digerido

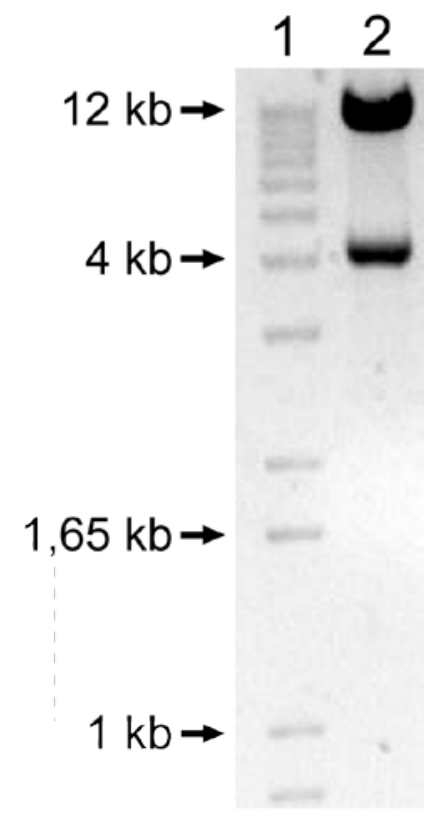

No poço 1, o marcador de peso molecular. No poço 2, o vetor pNL4-3 digerido com as enzimas Eco RI e SpeI, gerando dois fragmentos, o menor com 4236 bp, descartado, e o maior com 10588 bp, purificado para a ligação.

Fonte: Iamarino (2012).

Esta tática também se mostrou malsucedida, provavelmente por depender da ligação completa de quatro fragmentos. Para reduzir o número de fragmentos a serem ligados, a estratégia foi dividida em mais etapas.

\subsubsection{Inserção de sítios únicos de restrição intermediários.}

Devido à maior eficiência na amplificação de produtos de PCR, o sítio escolhido para o primeiro passo foi o BstBI. Com isso, foram necessários apenas três fragmentos para etapa ligação (descritos na Figura 30): um fragmento BstBI-BST de 3405 bp, a ser digerido com EcoRI (Figura 27); um fragmento BstBI-GNO, com 1872 bp, digerido com SpeI (Figura 31); e, por fim, o pNL4-3 selvagem digerido com SpeI e Eco RI (Figura 29). Todos fragmentos foram amplificados com sucesso, digeridos (Figura 32) e ligados. A ligação foi realizada e transformada com eficiência, e o plasmídeo pNL4-3 com o sítio BstBI foi criado (Figuras 33 e 34). A partir dele, se deu a etapa de inserção do sítio NotI. 
Figura 30 - Mapa do vetor utilizado para a criação do primeiro sítio

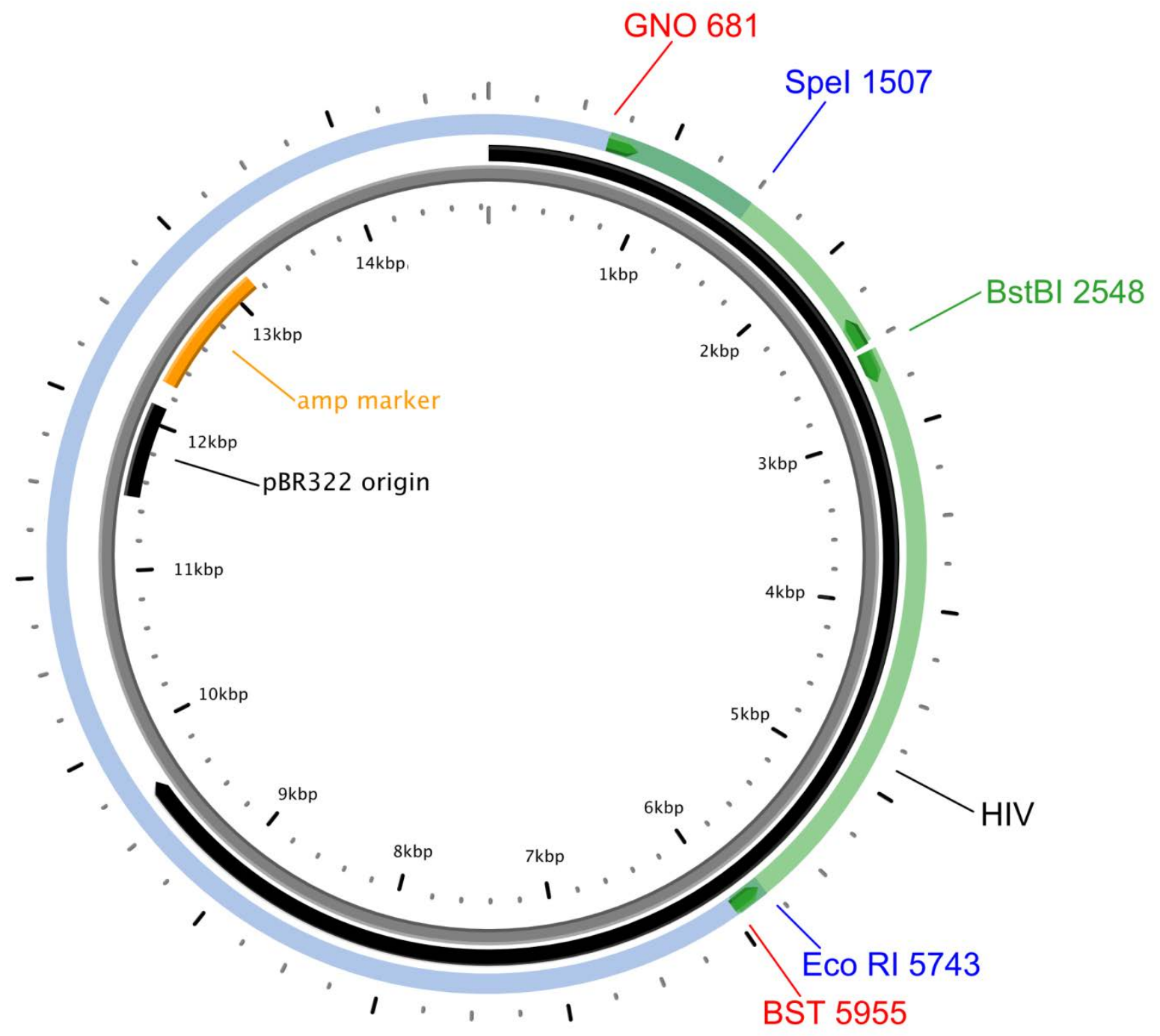

BstBI. Em vermelho estão os primers utilizados, em azul os sítios de restrição e em verde o sítio a ser criado.

Fonte: Iamarino (2012). 
Figura 31 - Fragmento BstBI-GNO amplificado

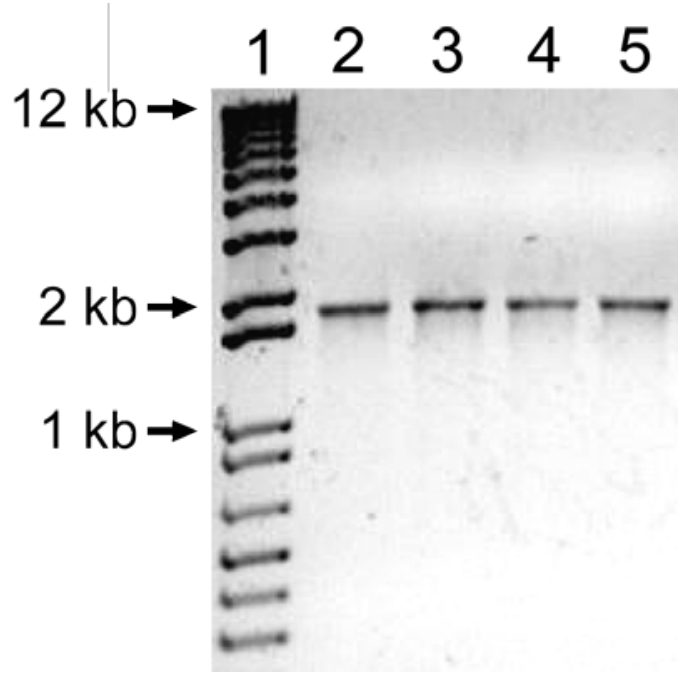

No poço 1, o marcador de tamanho. Nos poços 2 a 5, o fragmento BstBI-GNO (1872 bp) para a criação do sítio BstBI apenas.

Fonte: Iamarino (2012).

Figura 32 - Fragmentos da construção digeridos e purificados em gel para quantificação

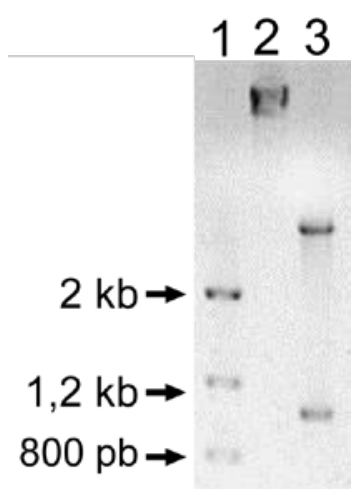

No poço 1, o marcador de peso e tamanho, com $100 \mathrm{ng}$ (2 kb), $60 \mathrm{ng}(1,2 \mathrm{~kb})$ e $40 \mathrm{ng}$ (800 pb) . No poço 2, o vetor pNL4-3 digerido com EcoRI e SpeI (10588 bp). No poço 3, fragmentos BstBI-GNO digerido com BstBI e SpeI (1046 bp) e BstBI-BST digerido com EcoRI e BstBI (3193 bp).

Fonte: Iamarino (2012). 
Figura 33 - Vetor pNL4-3 modificado com o sítio BstBI e digestão para confirmar a criação do sítio

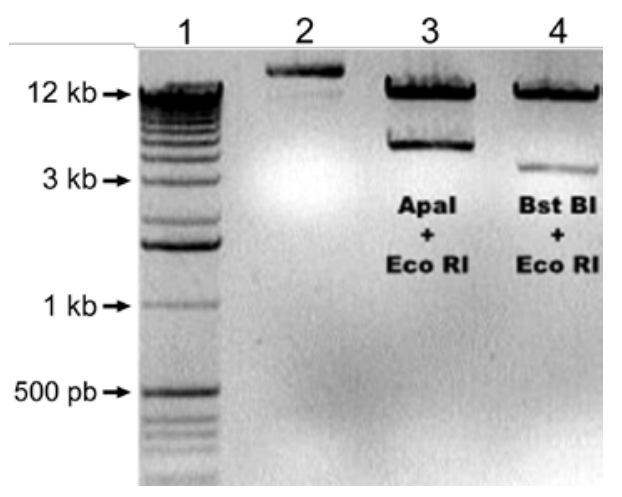

No poço 1, o marcador de peso molecular. No poço 2, o vetor não digerido. No poço 3, a digestão com ApaI e EcoRI, que gera um fragmento esperado menor de $3736 \mathrm{bp}$. No poço 4, a digestão com EcoRI e BstBI, sítio inexistente no vetor selvagem, gerando um fragmento menor de $3193 \mathrm{bp}$.

Fonte: Iamarino (2012).

Figura 34 - Mutações encontradas no vírus NL4-3_BstBI construído

Pn14-3

Pn14-3 BstBI

Primer_BstBI

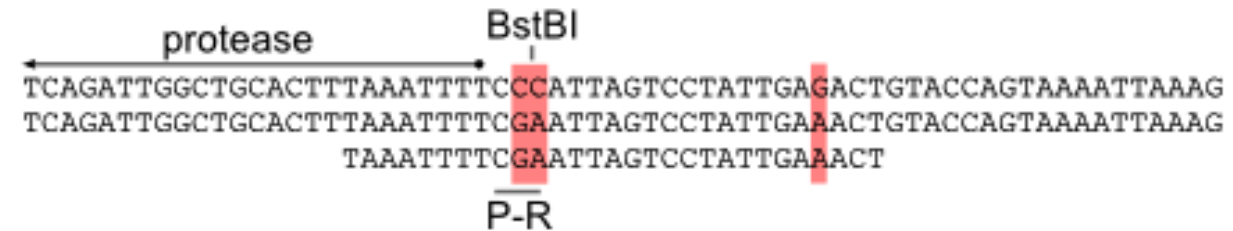

$\overline{\mathrm{P}-\mathrm{R}}$

As mudanças correspondem a bases propositalmente trocadas com o uso do primer desenhado (Primer_BstBI), para criação do sítio de clivagem único foi necessária a mutação do primeiro aminoácido da transcriptase reversa, de uma prolina para uma arginina. A segunda mudança corresponde a uma mutação silenciosa introduzida para facilitar o pareamento do primer com sequencia do subtipo $\mathrm{F}$.

Fonte: Iamarino (2012).

Para a inserção do sítio NotI foram amplificados dois fragmentos, de maneira similar à criação de BstBI: um fragmento NotI-GNO, digerido com SpeI; um fragmento NotI-BST amplificado a partir do plasmídeo construído com o sítio BstBI digerido com EcoRI; e o fragmento maior foi gerado com a digestão de pNL4-3 com SpeI e EcoRI. Não foi possível digerir e purificar o fragmento NotI-SpeI, uma vez que as duas metades desta digestão possuem um tamanho bastante similar, o que impossibilitou a separação de bandas e purificação do gel de agarose.

Para contornar estes problemas, novos sítios únicos de restrição foram utilizados, com os seguintes fragmentos: o produto da amplificação NotI-GNO foi digerido com NotI e ApaI, gerando dois fragmentos de tamanho bastante diferente; NotI-BstBI, que consiste da protease e já foi amplificado com sucesso anteriormente; 
e o plasmídeo pNL4-3 com o sítio BstBI construído anteriormente digerido com ApaI e BstBI (Figura 35). Porém, esta nova estratégia apresentou outra dificuldade. Enquanto a digestão anterior de EcoRI e SpeI gera dois fragmentos de tamanhos que permitem fácil separação no gel de agarose, uma vez que o vetor digerido possui 10580 bases e se distancia bastante do vetor não digerido com 14825 bases, o vetor digerido com BstBI e ApaI gera um fragmento menor descartado de 540 bases e o fragmento maior de 14385 bases, muito próximo do plasmídeo não digerido.

Figura 35 - Mapa do vetor utilizado para a criação do segundo sítio NotI utilizando outros primers e sítios de restrição

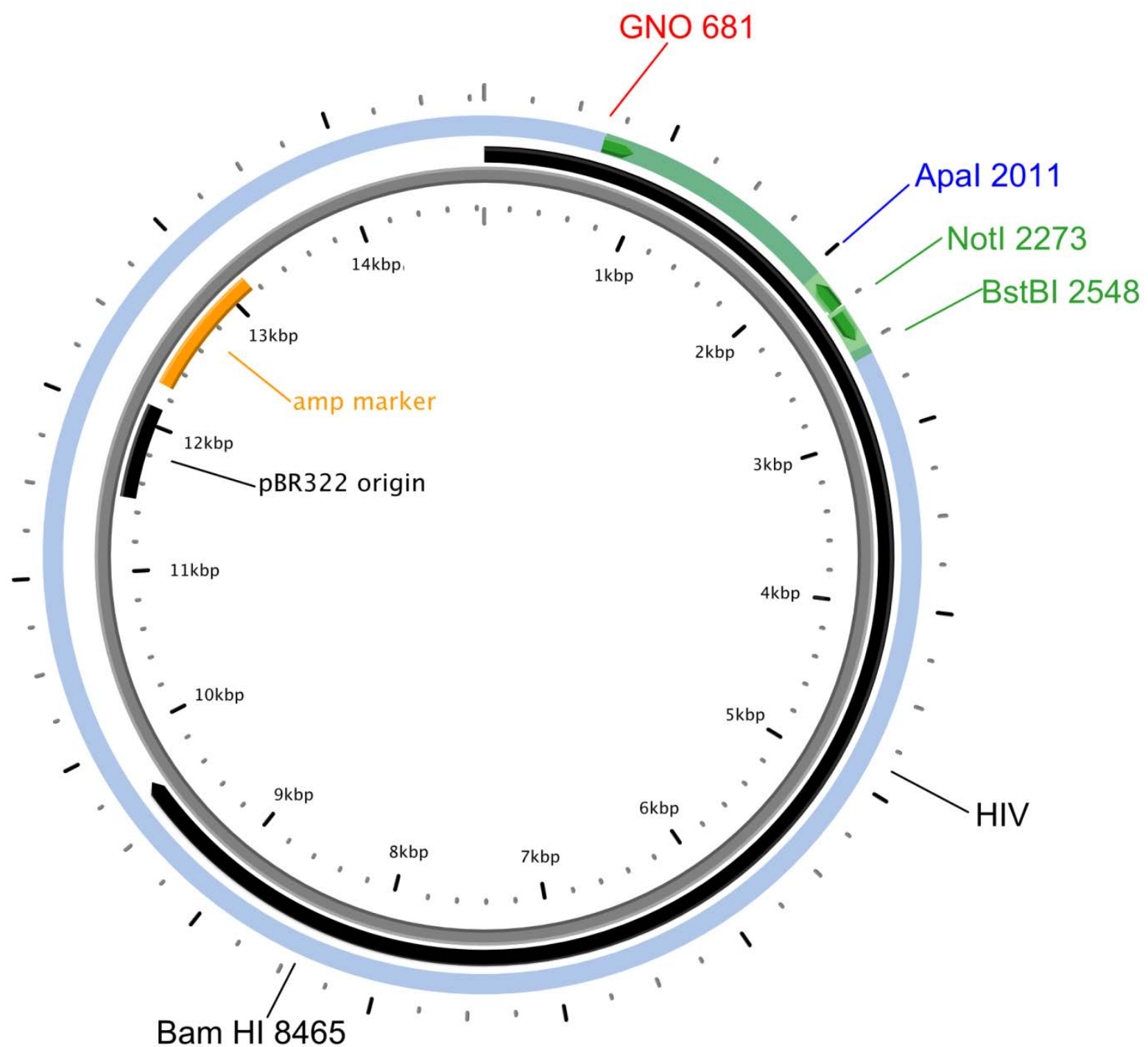

O sítio ApaI se localiza mais próximo do início da protease e gera dois fragmentos com uma diferença de tamanho menor.

Fonte: Iamarino (2012). 
Como última estratégia, foi utilizada uma terceira enzima, BamHI (Figura 35), que gerou dois fragmentos com um tamanho que permite uma melhor separação. Apesar deste outro sítio de restrição, não foi possível inserir o sítio NotI no vírus NL4-3. Assim, foi adotada a estratégia de inserir uma região de interesse que abrange do sítio único de restrição SpeI, que já ocorre no pNL4-3 na posição 1508 bp, até o final da protease, usando o sítio BstBI criado.

\subsubsection{Criação do vírus recombinante NL4-3_0063}

Com a utilização de um fragmento SpeI-BstBI, foi possível a criação de um vetor recombinante com a protease de interesse, bem como seu substrato, grande parte do gene gag portando quase todos os sítios de digestão pela enzima. Tal construção tem a vantagem de carregar no vírus recombinante o substrato original da protease, com a presença dos sítios de clivagem reconhecidos p24-p2, p2-p7, p7-p1 e p1-p6. Várias mutações em Gagjá foram relacionadas a vírus resistentes a protease, tanto em sítios de clivagem como fora deles (Gatanaga et al., 2002; Tamiya et al., 2004), e devem ajudar a compensar a mudança na atividade catalítica das proteases resistentes. Ao utilizar esta região, apenas o sítio p17-p24 não é incluso na gag construída, um dos sítios menos relevantes no surgimento de resistência a PIs (Dauber et al., 2002; Verheyen et al., 2006; Malet et al., 2007).

Figura 36 - Fragmento amplificado do paciente 0063

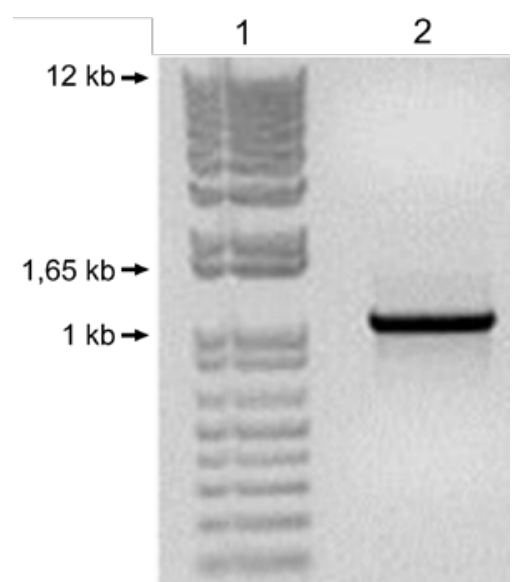

No poço 1, o marcador de peso molecular. No poço 2, o fragmento do paciente 0063. Fonte: Iamarino (2012).

O cDNA proviral do paciente 0063 foi utilizado (Figura 36) para a construção do vírus recombinante. Diferentemente da sequência da protease utilizada na modelagem e dinâmica molecular descritas no artigo anexo (ANEXO D, artigo 3), a 
sequência amplificada para a construção não contava com mutações de resistência, provavelmente tratando-se de um provírus integrado antes do início da terapia. Desta forma, o vetor recombinante construído conta com a sequência "naïve" de um vírus BF sabidamente capaz de sofrer mutações de resistência, que pode ser comparado em cultura com o controle B.

Figura 37 - Digestão do vetor pGEM-T contendo a sequência do paciente 0063

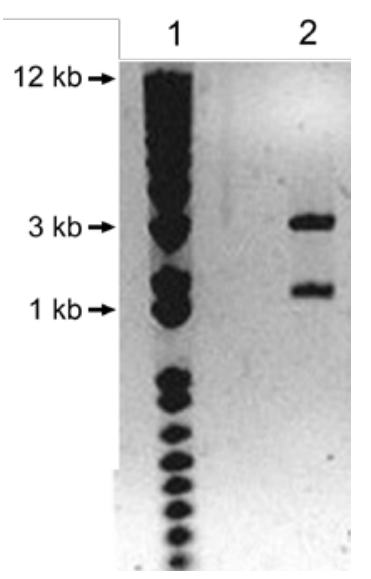

No poço 1, o marcador de peso molecular. No poço 2, a digestão com SpeI e BstBI do vetor pGEM-T ligado ao fragmento do paciente 0063, com dois fragmentos de tamanho esperado, cerca de $1 \mathrm{~kb}$ para a região SpeI-BstBI e cerca de $3 \mathrm{~kb}$ do vetor vazio.

Fonte: Iamarino (2012).

O fragmento amplificado foi ligado ao vetor pGEM. Com esta inserção, o fragmento gag-protease só pôde ser liberado do vetor com a clivagem de suas extremidades, garantindo que a digestão foi realizada (Figura 37). O fragmento foi digerido do pGEM e ligado aos fragmentos que integram o vetor pNL4-3 modificado, SpeI-EcoRI e BstBI-EcoRI, evitando o problema de contaminação com o vetor selvagem não digerido encontrado em etapas anteriores. Foram obtidas colônias transformadas com plasmídeo do tamanho esperado (Figura 38), e a digestão com EcoRI/ BstBI e EcoRI/ SpeI confirmou a presença dos sítios esperados (Figura 39). 
Figura 38 - DNA obtido das colônias transformadas

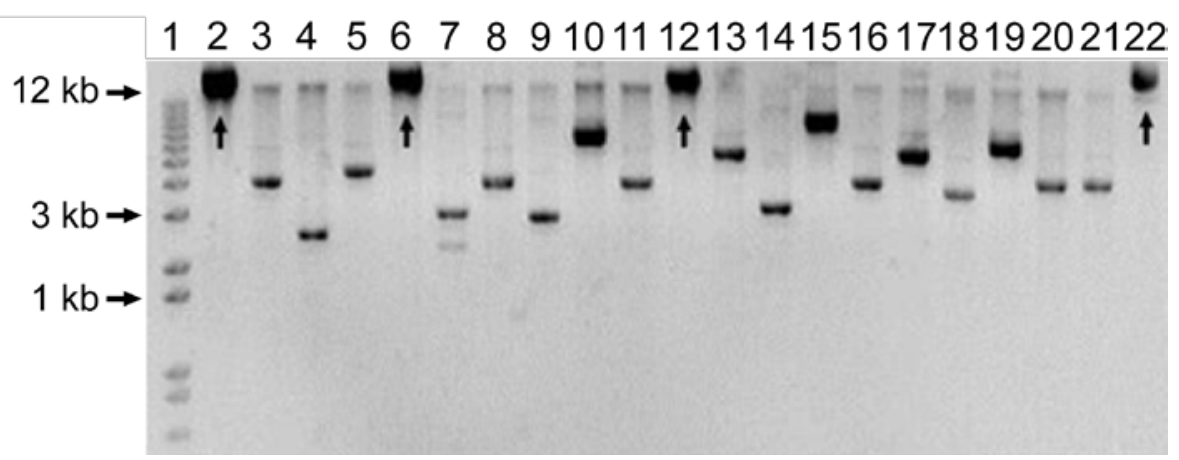

No poço 1, o marcador de peso molecular. Nos poços 2 a 22, a miniprep das colônias obtidas com a ligação do fragmento $0063 \mathrm{em} \mathrm{pNL} 4-3$. As setas indicam os plasmídeos com o tamanho esperado nos poços 2, 6, 12 e 22 .

Fonte: Iamarino (2012).

Figura 39 - Digestão dos transformantes de interesse

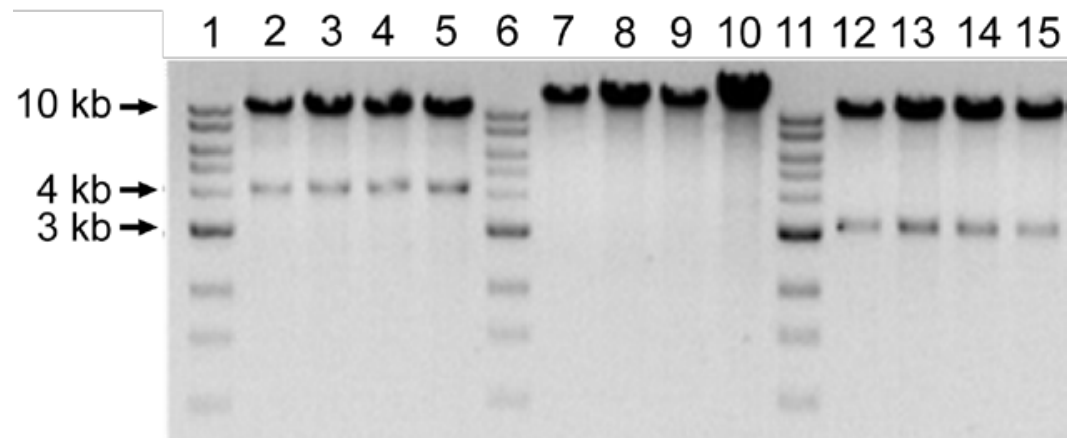

Nos poços 1, 6 e 11, o marcador de peso molecular. Digestão com SpeI/ EcoRI (poços 2 a 5) e BstBI/EcoRI (poços 12 a 15) dos plasmídeos obtidos das quatro colônias (Figura 38 não digeridos nos poços 7 a 10), revelando fragmentos de tamanho esperado: SpeI/ EcoRI com aproximadamente 4,2 kb e BstBI/ EcoRI com cerca de 3,2 kb.

Fonte: Iamarino (2012).

Para a confirmação de que se tratava da construção do vírus pNL4-3 recombinante com o fragmento do paciente 0063, e que o trecho inserido não sofreu deleções ou mutações que comprometessem a viabilidade viral, foi feito o sequenciamento da região de interesse. O sequenciamento realizado de 1200 a 3138 bp, que compreende o sítio SpeI utilizado e o sítio BstBI criado (ANEXO C), confirmou a criação do vírus recombinante (Figura 40). O fragmento originado do paciente 0063 possui uma protease sem mutações de resistência, e as mutações secundárias encontradas correspondem a polimorfismos típicos do subtipo F, L10V, M36I e L89M (Figura 41). A análise do perfil de recombinação revelou um trecho gag-protease recombinante BF, portador da protease inteira F (Figura 42), confirmando a construção. 
Figura 40 - Alinhamento sequências obtidas para montagem de contig pelo programa CodonCode

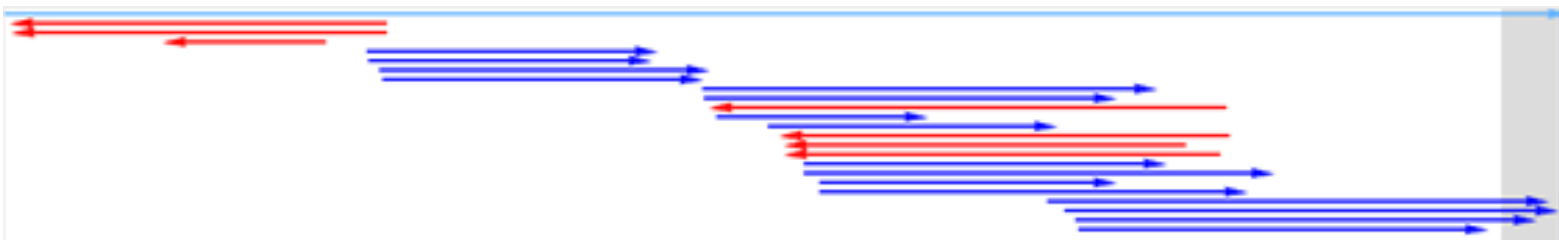

O trecho correspondente à região entre 1400 bp e 3300 bp do genoma do vírus NL4-3. Fonte: Iamarino (2012).

Figura 41 - Alinhamento de proteínas traduzidas do vírus construído com o paciente 0063 e o vírus NL4-3

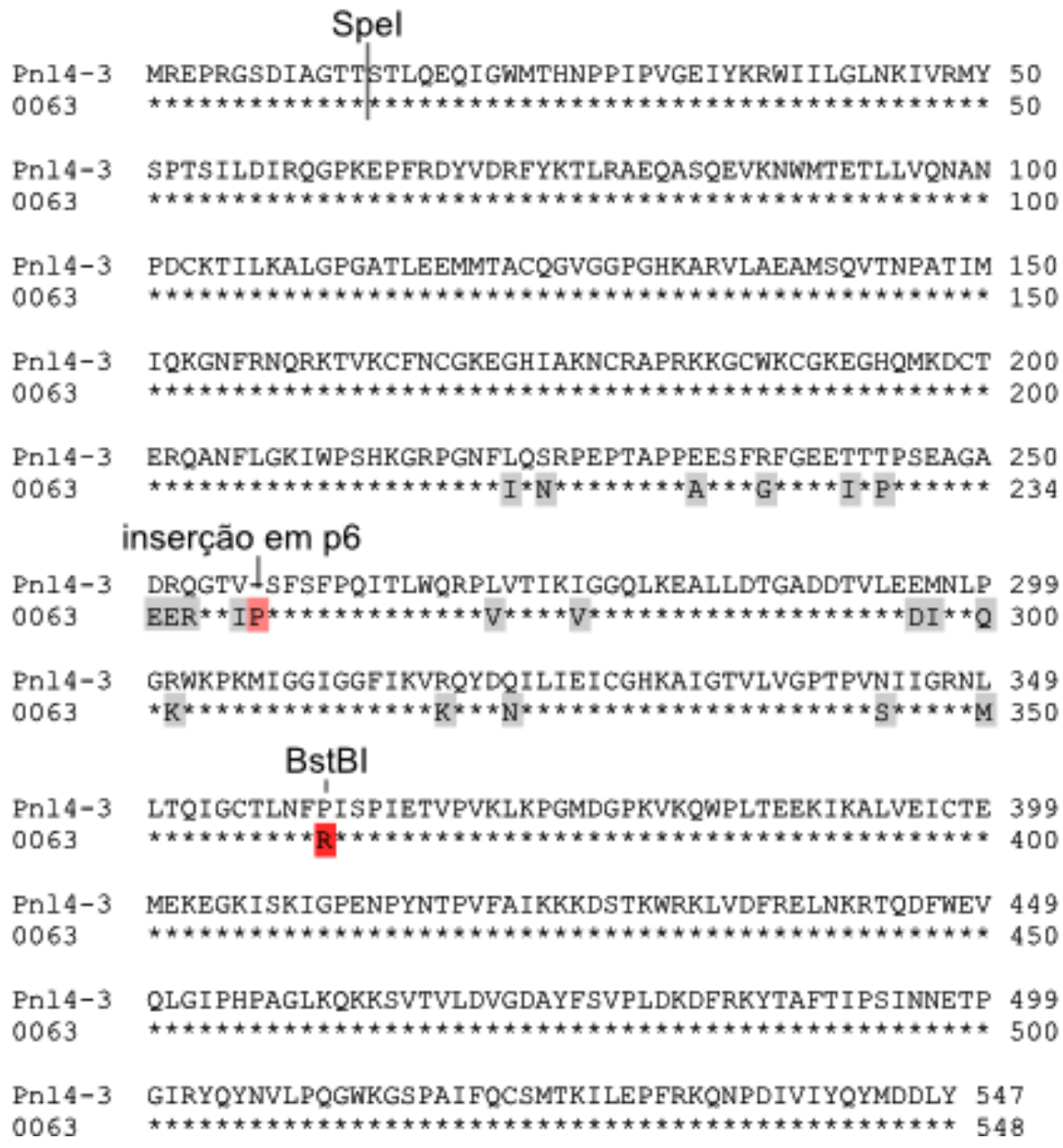

Os asteriscos representam regiões onde os aminoácidos são idênticos. A região p6 de Gag apresentou a inserção de uma prolina, marcada em vermelho. Também em vermelho está a mudança correspondente ao sítio de clivagem único criado no primeiro aminoácido da transcriptase reversa. Fonte: Iamarino (2012). 
Figura 42 - Perfil de recombinação do vírus NL4-3_0063 construído determinado pelo programajpHMM

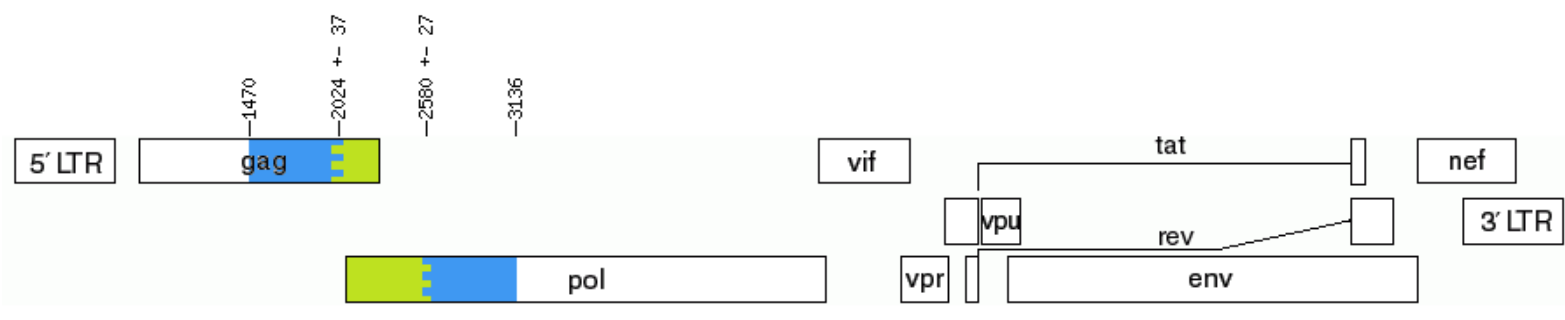

O começo do gene gag possui um trecho do subtipo B correspondente ao vetor (1470 a 1508 bp) e outro originário do paciente 0063 ( 1509 a 2042 bp). Em seguida um trecho correspondente ao final de gag e à protease do subtipo F, até o fim da região inserida (2553 bp).

Fonte: Iamarino (2012). 


\section{DISCUSSÃo}

\subsection{Integrase e a origem dos recombinantes BF}

O acréscimo de uma nova região ao sequenciamento já realizado pelo projeto VGDN permitiu a descoberta de 8 novos recombinantes BF entre 157 sequências analisadas $(\sim 5 \%)$. Este número ilustra bem a quantidade de recombinantes sendo gerada na região (Zhang et al., 2010), que não é amostrada quando poucos genes são sequenciados, caso da genotipagem. Outro fato que corrobora esta noção é o achado de que as 4 integrases recombinantes que compartilham um mesmo ponto de quebra estimado não possuem uma origem comum, sendo reconstruídas em ramos bastante distantes em todas as árvores filogenéticas construídas (Figura 17).

Este achado, associado à maior seleção positiva encontrada entre sequências do subtipo $\mathrm{B}$, indica uma rápida expansão de fragmentos do subtipo $\mathrm{F}$ dentro de uma epidemia já estabelecida, sem tempo ou pressão seletiva para que haja grande variabilidade, sugerindo algum valor evolutivo intrínseco em sequências do subtipo $F$ (Iamarino et al., 2012).

\subsection{Crescimento diferencial de recombinantes portadores de protease $F$}

A dinâmica de espalhamento diferencial do subtipo F é corroborada pela análise da epidemia de HIV-1 ocorrida na Argentina. Este país presenciou uma sobreposição do subtipo B por recombinantes BF como o subtipo mais prevalente encontrado durante a segunda metade da década de 1990 (Avila et al., 2002), associado ao aumento de casos entre heterossexuais, enquanto a epidemia entre homossexuais se manteve estável (Boletín ..., 2002).

Os resultados da dinâmica evolutiva destes vírus amostrados até o ano de 2000 suporta a interpretação de que esta mudança não se deu por competição entre linhagens, mas sim pela exploração de diferentes nichos e o crescimento diferencial de linhagens após a introdução da terapia intensiva (HAART) em 1996. Tal diferença pode ser vista pela súbita queda no tamanho efetivo da população do subtipo B ocorrido na segunda metade da década de 1990 (Figura 19), concordante com a mudança de grupo de risco mais comum no país. 
Como fator comum, que pode ajudar a compreender a resposta diferente entre os subtipos frente à terapia, todas as sequências analisadas portam a protease do subtipo F. Algo não exclusivo destas sequências, mais de $80 \%$ dos amostrados na Argentina possuem a protease deste subtipo (Petroni et al., 2006), correlacionada em 2005 por Brígido et al. com indivíduos com histórico de muitos tratamentos (Brigido et al., 2005). A protease é a região genômica do HIV-1 onde são encontradas as maiores diferenças em frequência de mutação entre subtipos (Carobene et al., 2004).

\subsection{A protease $F$ e mutações de resistência}

Simulações por dinâmica molecular já demonstraram diferenças estruturais da protease, como mudança nos flaps e na cavidade do sítio ativo (Seibold e Cukier, 2007). Mesmo a introdução manual de um inibidor dentro do sítio catalítico da proteína em sua conformação aberta foi capaz de induzir o fechamento dos flaps e a formação de pontes de hidrogênio que reproduzem dados estruturais empíricos (Hornak et al., 2006), indicando a fidelidade deste tipo de abordagem em demonstrar a interação entre proteína e ligante.

Curiosamente, mesmo sem mutações primárias, a protease selvagem do subtipo $\mathrm{F}$ apresentou uma menor afinidade pelo nelfinavir, similar às proteases do subtipo $\mathrm{B}$ resistentes, conforme a medida de energia livre de ligação (Tabela 5). Possivelmente, trata-se do efeito de resíduos específicos do subtipo F, como M36I e L89M, capazes de diminuir a interação com inibidores. A mutação M36 compromete a flexibilidade dos flaps (Sanches et al., 2007a) e pode favorecer o efeito de mutações primárias de resistência (Ode et al., 2007), especialmente entre outros subtipos que não o B (Lisovsky et al., 2010). Efeito observado na dinâmica molecular pelo menor RMSF dos resíduos do flap (Figura 20 e ANEXO D, artigo 3, Figura Suplementar 1), enquanto a mutação L89M possui um efeito análogo ao de L90M, ao diminuir os subsítios S1 e S1' (Sanches et al., 2007b).

Quanto às proteases resistentes, puderam ser observados dois tipos de efeito diferentes de mutações primárias em proteases F: em alguns casos, como o da protease 0450, a perda de afinidade pelo inibidor foi similar às proteases do subtipo B (Tabela 5), mas propriedades estruturais como a flutuação dos átomos da região S1 e S1' e de nelfinavir sugeriram um comportamento mais similar ao de proteases selvagens; e em outros casos, como as mutações M46L e V82A, as mesmas mutações 
provocaram uma maior perda de afinidade em proteases F (Tabela 5), conforme estimado pela energia de ligação.

Além da diferença em afinidade, um dos pacientes portadores de protease F, o 0732, possui uma protease com mutações de resistência primárias, mesmo nunca tendo sido tratado com PIs. Muito provavelmente se trata da transmissão de uma linhagem viral resistente. Dada sua data de diagnóstico, dezembro de 2002, e a data de coleta do material sequenciado no projeto VGDN, outubro de 2003, as mutações foram conservadas por pelo menos dez meses sem a terapia (Tabela 3 e ANEXO A). Embora a possibilidade de sequenciamento de um provírus integrado precocemente, ainda com as mutações, não possa ser descartada, a conservação destas mutações após o longo período de tempo indica que proteases $\mathrm{F}$ são capazes de manter a atividade catalítica mesmo na presença de mutações de resistência primária.

A simulação de proteases B e F derivadas de pacientes tratados e não tratados, portadoras de mutações de resistência primária similares que ocorreram in vivo, ajuda a esclarecer o que pode estar promovendo a dispersão do subtipo $\mathrm{F}$ entre sequências B. O método de estimativa de energia livre de ligação por LIE é indicado para casos como este, por suportar situações mais variáveis do que o método de FEP onde proteínas com diferentes resíduos são comparadas (Aqvist et al., 2002), e proteína e ligante são bastante conhecidos (Stjernschantz et al., 2006).

Ademais, estes achados são concordantes com resultados anteriores de dinâmica molecular (Batista et al., 2006), cristalografia de raios X (Sanches et al., 2007b) e ensaios enzimáticos da protease F purificada (Sanches et al., 2007b) demonstrando que, não só a protease F é capaz de reduzir sensivelmente mais sua afinidade por PIs na presença de mutações de resistência, com é naturalmente mais resistente a estes inibidores mesmo sem a presença de mutações primárias.

\subsection{A importância da recombinação para o HIV}

O papel da recombinação na evolução ainda é bastante debatido (Burt, 2000). Vírus de RNA, por exemplo, recombinam em grande frequência. $\mathrm{O}$ valor deste processo ainda não está claro na maioria dos casos, e o tamanho populacional e taxa de mutação parecem ser muito mais relevantes para sua dinâmica (Elena e Sanjuán, 2007). Já para o vírus da imunodeficiência humana, sua função é evidente. A 
recombinação é um evento comum entre retrovírus (Galetto e Negroni, 2005), e já era conhecida antes de ser observada no HIV (Ramirez et al., 2008). Mas, mesmo dentre os retrovírus, o HIV é especialmente recombinogênico, de dez a cem vezes mais do que outros como o MLV (Simon-Loriere e Holmes, 2011).

Para que a recombinação apresente uma vantagem evolutiva que possa ser selecionada, um dos pré-requisitos é a epistasia (Malmberg, 1977). A epistasia ocorre quando o efeito cumulativo de dois ou mais alelos (de genes inteiros a polimorfismos dentro de um mesmo gene) no fenótipo do organismo - fitness no caso dos vírus - é diferente do esperado pela contribuição individual de cada um deles. A epistasia pode ser positiva, quando a ocorrência de dois alelos sabidamente benéficos contribui mais para o fitness do que cada um deles individualmente, ou quando alelos negativos são menos prejudiciais para o fitness quando juntos. Já a epistasia negativa ocorre quando dois alelos benéficos juntos contribuem menos do que o esperado para o fitness, ou quando dois alelos negativos possuem um efeito maior no fitness quando combinados. Com a recombinação, pares de mutações que possuem um efeito atenuado ou acentuado podem ser transmitidos preferencialmente, ao invés de precisarem ocorrer de novo, passo a passo, acelerando a evolução do organismo.

Embora seus efeitos em organismos complexos ainda sejam discutidos (Macia et al., 2012), a epistasia positiva (Bonhoeffer et al., 2004) e negativa (Parera et al., 2009; Martinez et al., 2011) já foi demonstrada em HIV. Seu efeito aqui está diretamente relacionado com o surgimento de mutações associadas à resistência (Bonhoeffer et al., 2004), uma vez que a pressão seletiva imposta pelos antirretrovirais é suficientemente intensa, e a recombinação pode facilitar a ocorrência de pares favoráveis de alelos (Carvajal-Rodriguez et al., 2007).

Assim, o HIV possui as propriedades que permitem a recombinação: genoma diploide, uma transcriptase reversa propensa a troca de fita molde, e infeç̧ões crônicas que favorecem a co-infecção e superinfecção de pacientes. Além disso, ele está sujeito às pressões evolutivas que podem favorecer a recombinação, tais como epistasia e uma enorme pressão seletiva por parte do sistema imune e da terapia antirretroviral. Ademais, o HIV sofre variações exponenciais de tamanho de população viral em um paciente em curto espaço de tempo (Perelson et al., 1996), que implicam em uma relação complexa entre seleção e deriva nos mecanismos de estabelecimento (Brown, 1997; Zanotto et al., 1999) e transmissão de formas 
recombinantes. Sob certas circunstâncias, particularmente na competição em enormes populações, formas recombinantes precisariam ser providas de um grande fitness para sua fixação. De fato, o aumento de fitness decorrente da recombinação em HIV (Vijay et al., 2008) está diretamente associado ao surgimento de resistência a antirretrovirais (Moutouh et al., 1996; Carvajal-Rodriguez et al., 2007; Nora et al., 2007) e ao escape imune (Streeck et al., 2008).

Dentre os recombinantes $\mathrm{BF}$, também há evidências de vantagem adaptativa, tanto para um único vírion in vitro quanto populacional. A proteína Tat de recombinantes $\mathrm{BF}$ (CRF12_BF) apresentou maior capacidade de transativação da LTR, quando comparada com o subtipo B (Turk et al., 2006). E quando genes vpu de origem B ou $\mathrm{BF}$ foram introduzidos num vetor $\mathrm{B}$, observou-se uma maior capacidade replicativa dos vírus portadores do gene BF (De Candia et al., 2010). A epidemia causada pela CRF12_BF na Argentina se deu com uma taxa de crescimento populacional muito elevada (Aulicino et al., 2007), e taxas de crescimento aceleradas também foram descritas para recombinantes BF circulantes no Brasil (Leal et al., 2008) e no Uruguai (Bello et al., 2010).

\subsection{Os recombinantes BF}

Os motivos para a convergência de regiões de recombinação com origens distintas podem estar em propriedades virais que propiciam eventos de troca de fita molde em certas porções do genoma enquanto restringem em outros. A estrutura secundária de seu genoma de RNA altera a processividade da transcriptase reversa, gerando pontos mais propícios à parada e salto de fita molde, ao mesmo tempo em que torna certas regiões recombinantes inviáveis por depender de uma grande complementaridade de bases para formar os elaborados dobramentos (Watts et al., 2009). A variabilidade genética também pode influenciar, especialmente em porções mais conservadas do genoma (Magiorkinis et al., 2003). Porém, mais interessantes do que os motivos que proporcionam determinadas regiões de recombinação são as forças evolutivas que favorecem sua fixação na população.

O rápido espalhamento e a evolução do HIV se revelam em sua filogenia em formato de estrela. Em contato com uma enorme população suscetível e sem precisar enfrentar imunidade protetora ou qualquer terapia que impedisse sua transmissão durante as primeiras décadas, o vírus se espalhou livre de barreiras e possivelmente 
sem uma pressão evolutiva direcionadora. Tais características, combinados ao fato de que o subtipo B, predominante no começo da epidemia de HIV-1 em países desenvolvidos, ocorre em uma pequena fração da população em sua região de origem (menos de $2 \%$ dos casos na África Central (Los Alamos HIV database)) são fortes indicativos de um efeito fundador, que deu à primeira linhagem a circular espaço para que ela se tornasse a forma dominante (Tebit e Arts, 2011). O que não necessariamente reflete um fitness elevado, que permita sua propagação preferencial frente a competidores.

Uma vez presentes as condições que permitiram o espalhamento do HIV-1 em primeiro lugar, ondas seguintes provocadas por outras linhagens que não o subtipo $\mathrm{B}$ começaram a ocorrer, inclusive suplantando este subtipo. Na região Sul do país, por exemplo, o subtipo C já é responsável pela maioria dos novos casos, apesar de sua introdução e do espalhamento recente (Bello et al., 2012). Já a região Sudeste do Brasil sofreu uma epidemia repetida em parte pela Argentina alguns anos depois. Uma primeira onda entre HSHs e UDIs causada pelo subtipo B (Avila et al., 2002; Morgado et al., 2002), seguida quase uma década depois pela entrada do subtipo F. Aqui acaba parte desta semelhança.

Retrospectivamente, o subtipo $\mathrm{F}$ e recombinantes derivados foram encontrados muito antes na Argentina, com evidências de 1985 (Aulicino et al., 2011). No Brasil, as primeiras sequências deste subtipo foram encontradas quase uma década depois (Louwagie et al., 1993, 1994) - embora um dos pacientes recombinantes estudado aqui (0063) tenha sido diagnosticado em 1985 (Melo et al., 2011), não se pode afirmar com certeza que ele tenha sido infectado inicialmente por um vírus recombinante. Ao entrar no Brasil, o subtipo $F$ que se espalhou rapidamente pela população heterossexual argentina, possivelmente encontrou uma população em risco que já estava em grande parte colonizada pelo subtipo B. O que provocou a geração de muitas linhagens recombinantes $\mathrm{BF}$ que, tipadas com base em seu ponto de quebra, foram tidas como CRFs, quando nem todo o genoma é sequenciado e a convergência dos pontos de quebra não implica em ancestralidade comum.

Desta forma, recombinantes BF seguem como um dos maiores responsáveis por novos casos na América do Sul (Sucupira et al., 2007a; de Souza et al., 2008; Teixeira et al., 2010; Aulicino et al., 2011), gerando novas URFs e CRFs, como a reavaliação de recombinantes BF realizada por Zhang et al. (Zhang et al., 2010) indica, e dando 
sinais de que podem responder de maneira diferente ao tratamento. Evento que possui consequências inclusive em outros continentes, com a recente exportação dos recombinantes para a Europa (Bruselles et al., 2009; Gonzalez-Alba et al., 2011). Compreender seu espalhamento e a dinâmica formação de novos mosaicos, quais regiões são mais favoravelmente transmitidas e selecionadas, e como cada linhagem recombinante respondeu à introdução do HAART no Brasil e Argentina é de grande importância para o planejamento do combate à epidemia de AIDS. 


\section{CONCLUSÕES}

Apesar de compartilharem um ponto de quebra em comum, as integrases recombinantes mostram que o surgimento de recombinantes $\mathrm{BF}$ é um processo contínuo na epidemia local do HIV-1, e formas recombinantes com o mesmo perfil podem ser fruto de eventos distintos de recombinação, sem relação filogenética óbvia.

O crescimento contínuo de recombinantes BF e a queda do subtipo B coincidente com o aumento no número de casos de HIV-1 entre heterossexuais na epidemia argentina após a introdução do HAART não são compatíveis com a hipótese de competição, e sugerem um melhor desempenho de vírus portadores da protease $\mathrm{F}$ na presença da terapia.

A protease $\mathrm{F}$, quando comparada com proteases do subtipo B portadoras das mesmas mutações de resistência primária, possui um comportamento diferente, e pode apresentar uma afinidade muito menor pelo inibidor ou apresentar afinidade similar a proteases $\mathrm{B}$ resistentes mas manter uma conformação similar à protease selvagem.

A partir do cDNA do vírus BF isolado do paciente 0063 foi possível construir um clone infeccioso recombinante, com o esqueleto genômico do subtipo B proveniente do vírus NL4-3 e a porção terminal de gag e a protease do subtipo F sem mutações de resistência, que agora pode ser comparado ao subtipo B selvagem.

As propriedades da protease $\mathrm{F}$ medidas por dinâmica molecular apontam para uma enzima prontamente resistente a PIs e com maior vitalidade, ou seja, capaz de restaurar sua atividade apesar de mutações primárias que deveriam comprometer sua afinidade pelo substrato e processividade. O crescimento contínuo de recombinantes BF na Argentina e a geração constante de novas URFs no Brasil, em grande parte portadoras de protease $F$ (Brigido et al., 2005), apontam para um melhor desempenho destes recombinantes, mesmo sob a terapia intensiva implementada em ambos os países.

Juntos, tais fatos sugerem uma vantagem adaptativa de recombinantes $\mathrm{BF}$ sob terapia, que explicaria a predominância da protease $\mathrm{F}$ e uma região como Argentina e Brasil, onde a terapia antirretroviral é amplamente distribuída e possui uma 
cobertura de quase $100 \%$ dos casos. Desta forma, recombinantes BF podem estar se propagando mesmo em pacientes tratados, o que explicaria o crescimento contínuo de vírus $\mathrm{BF}$, indiferente aos fatores que provocaram a diminuição do crescimento do subtipo B observado na Argentina. Caso a epidemia se comporte desta maneira, o uso dos atuais inibidores de protease em pacientes portadores de protease $F$ não seria recomendável. Ao mesmo tempo, antirretrovirais que atacam outros alvos seriam preferíveis, e INIs poderiam ser adotados como terapia inicial para pacientes portadores de vírus recombinantes, e não como terapia de resgate. 


\section{REFERÊNCIAS *}

Acevedo O, Jorgensen WL. Advances in quantum and molecular mechanical $(\mathrm{QM} / \mathrm{MM})$ simulations for organic and enzymatic reactions. Acc Chem Res. 2010;43(1):142-51.

Adachi A, Gendelman HE, Koenig S, Folks T, Willey R, Rabson A, Martin MA. Production of acquired immunodeficiency syndrome-associated retrovirus in human and nonhuman cells transfected with an infectious molecular clone. J Virol. 1986;59(2):284-91.

Adachi M, Ohhara T, Kurihara K, Tamada T, Honjo E, Okazaki N, Arai S, Shoyama Y, Kimura K, Matsumura H, Sugiyama S, Adachi H, Takano K, Mori Y, Hidaka K, Kimura T, Hayashi Y, Kiso Y, Kuroki R. Structure of HIV-1 protease in complex with potent inhibitor KNI-272 determined by high-resolution X-ray and neutron crystallography. Proc Natl Acad Sci U S A. 2009;106(12):4641-6.

Aqvist J , Luzhkov VB, Brandsdal BO. Ligand binding affinities from MD simulations. Acc Chem Res. 2002;35(6):358-65.

Aqvist J, Medina C, Samuelsson JE. A new method for predicting binding affinity in computer-aided drug design. Protein Eng. 1994;7(3):385-91.

Arhel N. Revisiting HIV-1 uncoating. Retrovirology. 2010;7:96.

Arhel N, Genovesio A, Kim KA, Miko S, Perret E, Olivo-Marin JC, Shorte S, Charneau P. Quantitative four-dimensional tracking of cytoplasmic and nuclear HIV-1 complexes. Nat Methods. 2006;3(10):817-24.

Arruda LB, Fonseca LA, Duarte AJ, Casseb J. Genetic diversity on the integrase region of the pol gene among HIV type 1-infected patients naive for integrase inhibitors in Sao Paulo City, Brazil. AIDS Res Hum Retroviruses. 2010;26(1):105-7.

Aruksakunwong O, Wittayanarakul K, Sompornpisut P, Sanghiran V, Parasuk V, Hannongbua S. Structural and dynamical properties of different protonated states of mutant HIV-1 protease complexed with the saquinavir inhibitor studied by molecular dynamics simulations. J Mol Graph Model. 2006;25(3):324-32.

Ashorn P, McQuade TJ, Thaisrivongs S, Tomasselli AG, Tarpley WG, Moss B. An inhibitor of the protease blocks maturation of human and simian immunodeficiency viruses and spread of infection. Proc Natl Acad Sci USA. 1990;87(19):7472-6.

Aulicino PC, Bello G, Guimaraes ML, Ruchansky D, Rocco C, Mangano A, Morgado MG, Sen L. Longitudinal analysis of HIV-1 BF1 recombinant strains in vertically infected children from Argentina reveals a decrease in CRF12_BF pol gene mosaic patterns and high diversity of BF unique recombinant forms. Infect Genet Evol. 2011;11(2):349-57.

\footnotetext{
*De acordo com:

International Committee of Medical Journal Editors. Uniform requirements for manuscripts submitted to Biomedical Journal: sample references. Available from: http:// www.icmje.org [2011J uly 15]
} 
Aulicino PC, Holmes EC, Rocco C, Mangano A, Sen L. Extremely rapid spread of human immunodeficiency virus type $1 \mathrm{BF}$ recombinants in Argentina. J Virol. 2007;81(1):427-9.

Avila MM, Pando MA, Carrion G, Peralta LM, Salomon H, Carrillo MG, Sanchez J , Maulen S, Hierholzer J, Marinello M, Negrete M, Russell KL, Carr J K. Two HIV-1 epidemics in Argentina: different genetic subtypes associated with different risk groups. J Acquir Immune Defic Syndr. 2002;29(4):422-6.

Baker D, Sali A. Protein structure prediction and structural genomics. Science. 2001;294(5540):93-6.

Barre-Sinoussi F, Chermann J C, Rey F, Nugeyre MT, Chamaret S, Gruest J , Dauguet C, Axler-Blin C, Vezinet-Brun F, Rouzioux C, Rozenbaum W, Montagnier L. Isolation of a T-lymphotropic retrovirus from a patient at risk for acquired immune deficiency syndrome (AIDS). Science. 1983;220(4599):868-71.

Batista PR, Wilter A, Durham EH, Pascutti PG. Molecular dynamics simulations applied to the study of subtypes of HIV-1 protease common to Brazil, Africa, and Asia. Cell Biochem Biophys. 2006;44(3):395-404.

Beerli P, Felsenstein J . Maximum likelihood estimation of a migration matrix and effective population sizes in $\mathrm{n}$ subpopulations by using a coalescent approach. Proc Natl Acad Sci U S A. 2001;98(8):4563-8.

Bello G, Aulicino PC, Ruchansky D, Guimaraes ML, Lopez-Galindez C, Casado C, Chiparelli H, Rocco C, Mangano A, Sen L, Morgado MG. Phylodynamics of HIV-1 circulating recombinant forms 12 BF and 38_BF in Argentina and Uruguay. Retrovirology. 2010; 7:22.

Bello G, Eyer-Silva WA, Couto-Fernandez JC, Guimaraes ML, Chequer-Fernandez SL, Teixeira SL, Morgado MG. Demographic history of HIV-1 subtypes B and F in Brazil. Infection, Genetics and Evolution. 2007;7(2):263-70.

Bello G, Guimaraes ML, Morgado MG. Evolutionary history of HIV-1 subtype B and F infections in Brazil. AIDS. 2006;20(5):763-8.

Bello G, Zanotto PM, Iamarino A, Graf T, Pinto AR, Couto-Fernandez J C, Morgado MG. Phylogeographic Analysis of HIV-1 Subtype C Dissemination in Southern Brazil. Plos One. 2012;7(4):e35649.

Berendsen HJ C, Postma JPM, Gunsteren WFv, DiNola A, Haak JR. Molecular dynamics with coupling to an external bath. J Chem Phys. 1984;81(8):3684-90.

Berendsen HJ C, Postma J PM, van Gunsteren WF, Hermans J . Interaction models for water in relation to protein hydration. Intermolecular Forces. 1981:331-42.

Bieniasz PD. Late budding domains and host proteins in enveloped virus release. Virology. 2006;344(1):55-63. 
Bieniasz PD. The cell biology of HIV-1 virion genesis. Cell Host Microbe. 2009;5(6):550-8.

Black LR, Aiken C. TRIM5alpha disrupts the structure of assembled HIV-1 capsid complexes in vitro. J Virol. 2010;84(13):6564-9.

Boero M, Park J M, Hagiwara Y, Tateno M. First principles molecular dynamics study of catalytic reactions of biological macromolecular systems: toward analyses with QM/ MM hybrid molecular simulations. J Phys Condens Matter. 2007;19(36):365217.

Boletín sobre el SIDA en la República Argentina. Buenos Aires: Ministry of Health, National AIDS Program, August 2002. [Acessado em 2011 Mar 03] Disponível em: http:// www.msal.gov.ar/ sida/ boletines-anteriores.html. 2002.

Bonhoeffer S, Chappey C, Parkin NT, Whitcomb J M, Petropoulos CJ. Evidence for positive epistasis in HIV-1. Science. 2004;306(5701):1547-50.

Brass AL, Dykxhoorn DM, Benita Y, Yan N, Engelman A, Xavier RJ, Lieberman J, Elledge SJ. Identification of host proteins required for HIV infection through a functional genomic screen. Science. 2008;319(5865):921-6.

Briggs JA, Grunewald K, Glass B, Forster F, Krausslich HG, Fuller SD. The mechanism of HIV-1 core assembly: insights from three-dimensional reconstructions of authentic virions. Structure. 2006;14(1):15-20.

Briggs J A, Simon MN, Gross I, Krausslich HG, Fuller SD, Vogt VM, J ohnson MC. The stoichiometry of Gag protein in HIV-1. Nat Struct Mol Biol. 2004;11(7):672-5.

Briggs JA, Wilk T, Welker R, Krausslich HG, Fuller SD. Structural organization of authentic, mature HIV-1 virions and cores. EMBO J . 2003;22(7):1707-15.

Brigido LF, Franco HM, Custodio RM, Oliveira CA, JL PF, Eira M, Bergel F, Araujo F, Carvalheiro JR, Rodrigues R. Molecular characteristics of HIV type 1 circulating in Sao Paulo, Brazil. AIDS Res Hum Retroviruses. 2005;21(7):673-82.

Brindeiro R, Vanderborght B, Caride E, Correa L, Oravec RM, Berro O, Stuyver L, Tanuri A. Sequence diversity of the reverse transcriptase of human immunodeficiency virus type 1 from untreated Brazilian individuals. Antimicrob Agents Chemother. 1999;43(7):1674-80.

Brooks BR, Bruccoleri RE, Olafson BD, States DJ, Swaminathan S, Karplus M. CHARMM: A program for macromolecular energy, minimization, and dynamics calculations. J Comput Chem. 1983;4(2):187-217.

Brown AJ . Analysis of HIV-1 env gene sequences reveals evidence for a low effective number in the viral population. Proc Natl Acad Sci U S A. 1997;94(5):1862-5.

Brown AJ, Precious HM, Whitcomb J M, Wong JK, Quigg M, Huang W, Daar ES, D'Aquila RT, Keiser PH, Connick E, Hellmann NS, Petropoulos CJ, Richman DD, Little SJ . Reduced susceptibility of human immunodeficiency virus type 1 (HIV-1) from patients with primary HIV infection to nonnucleoside reverse transcriptase 
inhibitors is associated with variation at novel amino acid sites. J Virol. 2000;74(22):10269-73.

Brun-Vezinet F, Rouzioux C, Montagnier L, Chamaret S, Gruest J, Barre-Sinoussi F, Geroldi D, Chermann J C, McCormick J, Mitchell S, et al. Prevalence of antibodies to lymphadenopathy-associated retrovirus in African patients with AIDS. Science. 1984;226(4673):453-6.

Bruselles A, Rozera G, Bartolini B, Prosperi M, Del Nonno F, Narciso P, Capobianchi MR, Abbate I. Use of massive parallel pyrosequencing for near full-length characterization of a unique HIV Type $1 \mathrm{BF}$ recombinant associated with a fatal primary infection. AIDS Res Hum Retroviruses. 2009;25(9):937-42.

Burt A. Perspective: sex, recombination, and the efficacy of selection--was Weismann right? Evolution. 2000;54(2):337-51.

Buzon MJ, Massanella M, Llibre J M, Esteve A, Dahl V, Puertas MC, Gatell J M, Domingo P, Paredes R, Sharkey M, Palmer S, Stevenson M, Clotet B, Blanco J, Martinez-Picado J. HIV-1 replication and immune dynamics are affected by raltegravir intensification of HAART-suppressed subjects. Nat Med. 2010;16(4):4605.

Calazans A, Brindeiro R, Brindeiro P, Verli H, Arruda MB, Gonzalez LM, Guimaraes JA, Diaz RS, Antunes OA, Tanuri A. Low accumulation of L90M in protease from subtype F HIV-1 with resistance to protease inhibitors is caused by the L89M polymorphism. J Infect Dis. 2005;191(11):1961-70.

Campbell S, Rein A. In vitro assembly properties of human immunodeficiency virus type 1 Gag protein lacking the p6 domain. J Virol. 1999;73(3):2270-9.

Carlson HA, J orgensen WL. An Extended Linear Response Method for Determining Free Energies of Hydration. J Phys Chem. 1995;99(26):10667-73.

Carobene MG, Rubio AE, Carrillo MG, Maligne GE, Kijak GH, Quarleri JF, Salomon $\mathrm{H}$. Differences in frequencies of drug resistance-associated mutations in the HIV-1 pol gene of B subtype and BF intersubtype recombinant samples. J Acquir Immune Defic Syndr. 2004;35(2):207-9.

Carr J K, Avila M, Gomez Carrillo M, Salomon H, Hierholzer J, Watanaveeradej V, Pando MA, Negrete M, Russell KL, Sanchez J, Birx DL, Andrade R, Vinoles J, McCutchan FE. Diverse BF recombinants have spread widely since the introduction of HIV-1 into South America. AIDS. 2001;15(15):F41-7.

Carr JK, Salminen MO, Albert J, Sanders-Buell E, Gotte D, Birx DL, McCutchan FE. Full genome sequences of human immunodeficiency virus type 1 subtypes $G$ and $A / G$ intersubtype recombinants. Virology. 1998;247(1):22-31.

Carr JK, Salminen MO, Koch C, Gotte D, Artenstein AW, Hegerich PA, St Louis D, Burke DS, McCutchan FE. Full-length sequence and mosaic structure of a human immunodeficiency virus type 1 isolate from Thailand. J Virol. 1996; 70(9):5935-43. 
Carvajal-Rodriguez A, Crandall KA, Posada D. Recombination favors the evolution of drug resistance in HIV-1 during antiretroviral therapy. Infect Genet Evol. 2007;7(4):476-83.

Casado C, Pernas M, Alvaro T, Sandonis V, Garcia S, Rodriguez C, del Romero J, Grau E, Ruiz L, Lopez-Galindez C. Coinfection and superinfection in patients with long-term, nonprogressive HIV-1 disease. J Infect Dis. 2007;196(6):895-9.

Ceccherini-Silberstein F, Malet I, D'Arrigo R, Antinori A, Marcelin AG, Perno CF. Characterization and structural analysis of HIV-1 integrase conservation. AIDS Rev. 2009;11(1):17-29.

Ceccherini-Silberstein F, Malet I, Fabeni L, Dimonte S, Svicher V, D'Arrigo R, Artese A, Costa G, Bono S, Alcaro S, Monforte A, Katlama C, Calvez V, Antinori A, Marcelin AG, Perno CF. Specific HIV-1 integrase polymorphisms change their prevalence in untreated versus antiretroviral-treated HIV-1-infected patients, all naive to integrase inhibitors. J Antimicrob Chemother. 2010;65(11):2305-18.

Chan DC, Kim PS. HIV entry and its inhibition. Cell. 1998;93(5):681-4.

Chang SY, Bowman BH, Weiss J B, Garcia RE, White TJ . The origin of HIV-1 isolate HTLV-IIIB. Nature. 1993;363(6428):466-9.

Charnay N, Ivanyi-Nagy R, Soto-Rifo R, Ohlmann T, Lopez-Lastra M, Darlix J L. Mechanism of HIV-1 Tat RNA translation and its activation by the Tat protein. Retrovirology. 2009;6:74.

Chen X, Weber IT, Harrison RW. Molecular dynamics simulations of 14 HIV protease mutants in complexes with indinavir. J Mol Model. 2004;10(5-6):373-81.

Chequer P, Cuchi P, Mazin R, Garcia Calleja J M. Access to antiretroviral treatment in Latin American countries and the Caribbean. AIDS. 2002;16 Suppl 3:S50-7.

Cherepanov P, Maertens GN, Hare S. Structural insights into the retroviral DNA integration apparatus. Curr Opin Struct Biol. 2011;21(2):249-56.

Chinea G, Padron G, Hooft RWW, Sander C, Vriend G. The use of position-specific rotamers in model building by homology. Proteins: Structure, Function, and Bioinformatics. 1995;23(3):415-21.

Choe H, Farzan M, Sun Y, Sullivan N, Rollins B, Ponath PD, Wu L, Mackay CR, LaRosa G, Newman W, Gerard N, Gerard C, Sodroski J. The beta-chemokine receptors CCR3 and CCR5 facilitate infection by primary HIV-1 isolates. Cell. 1996;85(7):1135-48.

Chohan B, Lavreys L, Rainwater SM, Overbaugh J . Evidence for frequent reinfection with human immunodeficiency virus type 1 of a different subtype. J Virol. 2005;79(16):10701-8.

Chothia C, Lesk AM. The relation between the divergence of sequence and structure in proteins. EMBO J . 1986;5(4):823-6. 
Ciuffi A. Mechanisms governing lentivirus integration site selection. Curr Gene Ther. 2008;8(6):419-29.

Clavel F, Guetard D, Brun-Vezinet F, Chamaret S, Rey MA, Santos-Ferreira MO, Laurent AG, Dauguet C, Katlama C, Rouzioux C, et al. Isolation of a new human retrovirus from West African patients with AIDS. Science. 1986;233(4761):343-6.

Clemente J C, Moose RE, Hemrajani R, Whitford LR, Govindasamy L, Reutzel R, McKenna R, Agbandje-McKenna M, Goodenow MM, Dunn BM. Comparing the accumulation of active- and nonactive-site mutations in the HIV-1 protease. Biochemistry. 2004a;43(38):12141-51.

Clemente JC, Moose RE, Hemrajani R, Whitford LRS, Govindasamy L, Reutzel R, McKenna R, Agbandje-McKenna M, Goodenow MM, Dunn BM. Comparing the Accumulation of Active- and Nonactive-Site Mutations in the HIV-1 Proteaset. Biochemistry. 2004b;43(38):12141-51.

Clerc O, Colombo S, Yerly S, Telenti A, Cavassini M. HIV-1 elite controllers: beware of super-infections. J Clin Virol. 2010;47(4):376-8.

Coffin J, Haase A, Levy J A, Montagnier L, Oroszlan S, Teich N, Temin H, Toyoshima $\mathrm{K}$, Varmus H, Vogt P, Weiss R. Human Immunodeficiency Viruses. Science. 1986;232(4751):697.

Coffin J M. HIV population dynamics in vivo: implications for genetic variation, pathogenesis, and therapy. Science. 1995;267(5197):483-9.

Cohen SS. A strategy for the chemotherapy of infectious disease. Science. 1977;197(4302):431-2.

Collins JR, Burt SK, Erickson JW. Flap opening in HIV-1 protease simulated by 'activated' molecular dynamics. Nat Struct Biol. 1995;2(4):334-8.

Collins KL, Chen BK, Kalams SA, Walker BD, Baltimore D. HIV-1 Nef protein protects infected primary cells against killing by cytotoxic T lymphocytes. Nature. 1998;391(6665):397-401.

Condra J H, Schleif WA, Blahy OM, Gabryelski LJ, Graham DJ, Quintero JC, Rhodes A, Robbins HL, Roth E, Shivaprakash M. In vivo emergence of HIV-1 variants resistant to multiple protease inhibitors. Nature. 1995;374(6522):569-71.

Cornell WD, Cieplak P, Bayly CI, Gould IR, Merz KM, Ferguson DM, Spellmeyer DC, Fox T, Caldwell JW, Kollman PA. A Second Generation Force Field for the Simulation of Proteins, Nucleic Acids, and Organic Molecules. J Am Chem Soc. 1995;117(19):5179-97.

CraigJ C, Duncan IB, Hockley D, Grief C, Roberts NA, Mills J S. Antiviral properties of Ro 31-8959, an inhibitor of human immunodeficiency virus (HIV) proteinase. Antiviral Res. 1991;16(4):295-305. 
Crawford S, Goff SP. A deletion mutation in the 5' part of the pol gene of Moloney murine leukemia virus blocks proteolytic processing of the gag and pol polyproteins. J Virol. 1985;53(3):899-907.

Croxtall JD, Keam SJ. Raltegravir: a review of its use in the management of HIV infection in treatment-experienced patients. Drugs. 2009;69(8):1059-75.

Cullen BR. Nuclear mRNA export: insights from virology. Trends Biochem Sci. 2003;28(8):419-24.

Czodrowski P, Sotriffer CA, Klebe G. Atypical protonation states in the active site of HIV-1 protease: a computational study. J Chem Inf Model. 2007;47(4):1590-8.

Daniel MD, Letvin NL, King NW, Kannagi M, Sehgal PK, Hunt RD, Kanki PJ, Essex M, Desrosiers RC. Isolation of T-cell tropic HTLV-III-like retrovirus from macaques. Science. 1985;228(4704):1201-4.

Darden T, York D, Pedersen L. Particle mesh Ewald: An N [center-dot] $\log (\mathrm{N})$ method for Ewald sums in large systems. The Journal of Chemical Physics. 1993;98(12):10089-92.

Dauber DS, Ziermann R, Parkin N, Maly DJ, Mahrus S, Harris JL, Ellman JA, Petropoulos C, Craik CS. Altered substrate specificity of drug-resistant human immunodeficiency virus type 1 protease. J Virol. 2002;76(3):1359-68.

Daugherty MD, Booth DS, Jayaraman B, Cheng Y, Frankel AD. HIV Rev response element (RRE) directs assembly of the Rev homooligomer into discrete asymmetric complexes. Proc Natl Acad Sci U S A. 2010a;107(28):12481-6.

Daugherty MD, Liu B, Frankel AD. Structural basis for cooperative RNA binding and export complex assembly by HIV Rev. Nat Struct Mol Biol. 2010b;17(11):1337-42.

Davies DR. The structure and function of the aspartic proteinases. Annu Rev Biophys Biophys Chem. 1990;19:189-215.

De Candia C, Espada C, Duette G, Ghiglione Y, Turk G, Salomon H, Carobene M. Viral replication is enhanced by an HIV-1 intersubtype recombination-derived Vpu protein. Virol J. 2010; 7:259.

De Clercq E. The design of drugs for HIV and HCV. Nat Rev Drug Discov. 2007;6(12):1001-18.

De Sa Filho DJ, Sucupira MC, Caseiro MM, Sabino EC, Diaz RS, Janini LM. Identification of two HIV type 1 circulating recombinant forms in Brazil. AIDS Res Hum Retroviruses. 2006;22(1):1-13.

de Souza AC, de Oliveira CM, Rodrigues CL, Silva SA, Levi J E. Short communication: Molecular characterization of HIV type $1 \mathrm{BF}$ pol recombinants from Sao Paulo, Brazil. AIDS Res Hum Retroviruses. 2008;24(12):1521-5. 
de Souza ON, Ornstein RL. Effect of periodic box size on aqueous molecular dynamics simulation of a DNA dodecamer with particle-mesh Ewald method. Biophys J . 1997; 72(6):2395-7.

Del Portillo A, Tripodi J, Najfeld V, Wodarz D, Levy DN, Chen BK. Multiploid inheritance of HIV-1 during cell-to-cell infection. J Virol. 2011;85(14):7169-76.

Delgado E, Ríos M, Fernández J, Pérez-Álvarez L, Nájera R, Thomson MM. Identification of a New HIV Type 1 BF Intersubtype Circulating Recombinant Form (CRF44_BF) in Chile. AIDS Res Hum Retroviruses. 2010;26(7):821-6.

Deng H, Liu R, Ellmeier W, Choe S, Unutmaz D, Burkhart M, Di Marzio P, Marmon S, Sutton RE, Hill CM, Davis CB, Peiper SC, Schall TJ, Littman DR, Landau NR. Identification of a major co-receptor for primary isolates of HIV-1. Nature. 1996;381(6584):661-6.

Dilernia DA, J ones LR, Pando MA, Rabinovich RD, Damilano GD, Turk G, Rubio AE, Pampuro S, Gomez-Carrillo M, Salomon H. Analysis of HIV type 1 BF recombinant sequences from South America dates the origin of CRF12_BF to a recombination event in the 1970s. AIDS Res Hum Retroviruses. 2011;27(5):569-78.

Dirauf P, Meiselbach H, Sticht H. Effects of the V82A and I54V mutations on the dynamics and ligand binding properties of HIV-1 protease. J Mol Model. 2010.

Dorr P, Westby M, Dobbs S, Griffin P, Irvine B, Macartney M, Mori J, Rickett G, Smith-Burchnell C, Napier C, Webster R, Armour D, Price D, Stammen B, Wood A, Perros M. Maraviroc (UK-427,857), a potent, orally bioavailable, and selective smallmolecule inhibitor of chemokine receptor CCR5 with broad-spectrum anti-human immunodeficiency virus type 1 activity. Antimicrob Agents Chemother. 2005;49(11):4721-32.

Dragic T, Litwin V, Allaway GP, Martin SR, Huang Y, Nagashima KA, Cayanan C, Maddon PJ, Koup RA, Moore JP, Paxton WA. HIV-1 entry into CD4+ cells is mediated by the chemokine receptor CC-CKR-5. Nature. 1996;381(6584):667-73.

Drummond AJ, Rambaut A. BEAST: Bayesian evolutionary analysis by sampling trees. BMC Evol Biol. 2007; 7:214.

Dunbrack RL, Jr., Karplus M. Conformational analysis of the backbone-dependent rotamer preferences of protein sidechains. Nat Struct Biol. 1994;1(5):334-40.

Easterbrook PJ, Newson R, Ives N, Pereira S, Moyle G, Gazzard BG. Comparison of virologic, immunologic, and clinical response to five different initial protease inhibitor-containing and nevirapine-containing regimens. J Acquir Immune Defic Syndr. 2001;27(4):350-64.

Elena SF, Sanjuán R. Virus Evolution: Insights from an Experimental Approach. Annual Review of Ecology, Evolution, and Systematics. 2007;38(1):27-52.

Engelman A. Reverse transcription and integration. In: Kurth R, Bannert N, editors. Retroviruses: molecular biology, genomics and pathogenesis 
Norfolk: Caister Academic Press; 2010. p. 129-59.

Engelman A, Cherepanov P. The lentiviral integrase binding protein LEDGF/p75 and HIV-1 replication. PLoS Pathog. 2008;4(3):e1000046.

Engelman A, Englund G, Orenstein JM, Martin MA, Craigie R. Multiple effects of mutations in human immunodeficiency virus type 1 integrase on viral replication. J Virol. 1995;69(5):2729-36.

Erickson JW, Burt SK. Structural mechanisms of HIV drug resistance. Annu Rev Pharmacol Toxicol. 1996;36:545-71.

Esnouf R, Ren J , Ross C, J ones Y, Stammers D, Stuart D. Mechanism of inhibition of HIV-1 reverse transcriptase by non-nucleoside inhibitors. Nat Struct Biol. 1995;2(4):303-8.

Essmann U, Perera L, Berkowitz ML, Darden T, Lee H, Pedersen LG. A smooth particle mesh Ewald method. The Journal of Chemical Physics. 1995;103(19):857793.

Feller SE, Pastor RW, Rojnuckarin A, Bogusz S, Brooks BR. Effect of Electrostatic Force Truncation on Interfacial and Transport Properties of Water. The J ournal of Physical Chemistry. 1996;100(42):17011-20.

Felsenstein J. Phylogenies from Molecular Sequences: Inference and Reliability. Annu Rev Genet. 1988;22(1):521-65.

Feng Y, Broder CC, Kennedy PE, Berger EA. HIV-1 entry cofactor: functional cDNA cloning of a seven-transmembrane, G protein-coupled receptor. Science. 1996;272(5263):872-7.

Fernández-García A, Pérez-Álvarez L, Cuevas MT, Delgado E, Muñoz-Nieto M, Cilla G, Iribarren JA, Pinilla M, Ocampo A, Miralles C, Pérez-Castro S, González-Galeano M, De Castro RO, Trigo M, García V, Sánchez AM, Thomson MM. Identification of a New HIV Type 1 Circulating BF Intersubtype Recombinant Form (CRF47_BF) in Spain. AIDS Res Hum Retroviruses. 2010;26(7):827-32.

Fischl MA, Richman DD, Grieco MH, Gottlieb MS, Volberding PA, Laskin OL, Leedom JM, Groopman JE, Mildvan D, Schooley RT, et al. The efficacy of azidothymidine (AZT) in the treatment of patients with AIDS and AIDS-related complex. A double-blind, placebo-controlled trial. N Engl J Med. 1987;317(4):185-91.

Fitzgerald PM, McKeever BM, VanMiddlesworth J F, Springer JP, Heimbach JC, Leu CT, Herber WK, Dixon RA, Darke PL. Crystallographic analysis of a complex between human immunodeficiency virus type 1 protease and acetyl-pepstatin at 2.0-A resolution. J Biol Chem. 1990;265(24):14209-19.

Frankel AD, Young JA. HIV-1: fifteen proteins and an RNA. Annu Rev Biochem. 1998;67:1-25. 
Freedberg DI, Ishima R, Jacob J, Wang YX, Kustanovich I, Louis J M, Torchia DA. Rapid structural fluctuations of the free HIV protease flaps in solution: relationship to crystal structures and comparison with predictions of dynamics calculations. Protein Sci. 2002;11(2):221-32.

Frenkel LM, Wang Y, Learn GH, McKernan JL, Ellis GM, Mohan KM, Holte SE, De Vange SM, Pawluk DM, Melvin AJ, Lewis PF, Heath LM, Beck IA, Mahalanabis M, Naugler WE, Tobin NH, Mullins J I. Multiple viral genetic analyses detect low-level human immunodeficiency virus type 1 replication during effective highly active antiretroviral therapy. J Virol. 2003;77(10):5721-30.

Galetto R, Negroni M. Mechanistic features of recombination in HIV. AIDS Rev. 2005; 7(2):92-102.

Gallo RC, Salahuddin SZ, Popovic M, Shearer GM, Kaplan M, Haynes BF, Palker TJ , Redfield R, Oleske J, Safai B, et al. Frequent detection and isolation of cytopathic retroviruses (HTLV-III) from patients with AIDS and at risk for AIDS. Science. 1984;224(4648):500-3.

Gallo RC, Sarin PS, Gelmann EP, Robert-Guroff M, Richardson E, Kalyanaraman VS, Mann D, Sidhu GD, Stahl RE, Zolla-Pazner S, Leibowitch J , Popovic M. Isolation of human T-cell leukemia virus in acquired immune deficiency syndrome (AIDS). Science. 1983;220(4599):865-7.

Gallo SA, Finnegan CM, Viard M, Raviv Y, Dimitrov A, Rawat SS, Puri A, Durell S, Blumenthal R. The HIV Env-mediated fusion reaction. Biochim Biophys Acta. 2003; 1614(1):36-50.

Ganser-Pornillos BK, Yeager M, Sundquist WI. The structural biology of HIV assembly. Curr Opin Struct Biol. 2008;18(2):203-17.

Gao F, Bailes E, Robertson DL, Chen Y, Rodenburg CM, Michael SF, Cummins LB, Arthur LO, Peeters M, Shaw GM, Sharp PM, Hahn BH. Origin of HIV-1 in the chimpanzee Pan troglodytes troglodytes. Nature. 1999;397(6718):436-41.

Gao F, Robertson DL, Morrison SG, Hui HX, Craig S, Decker J , Fultz PN, Girard M, Shaw GM, Hahn BH, Sharp PM. The heterosexual human immunodeficiency virus type 1 epidemic in Thailand is caused by an intersubtype (A/E) recombinant of African origin. J Virol. 1996;70(10):7013-29.

Garcia JV, Miller AD. Serine phosphorylation-independent downregulation of cellsurface CD4 by nef. Nature. 1991;350(6318):508-11.

Garrett L. A próxima peste: as doenças de um mundo em desequilíbrio. Rio de J aneiro: Editora Nova Fronteira; 1995.

Gatanaga H, Suzuki Y, Tsang H, Yoshimura K, Kavlick MF, Nagashima K, Gorelick RJ, Mardy S, Tang C, Summers MF, Mitsuya H. Amino acid substitutions in Gag protein at non-cleavage sites are indispensable for the development of a high multitude of $\mathrm{HIV}-1$ resistance against protease inhibitors. J Biol Chem. 2002;277(8):5952-61. 
Ghosh AK, Sridhar PR, Leshchenko S, Hussain AK, Li J, Kovalevsky AY, Walters DE, Wedekind JE, Grum-Tokars V, Das D, Koh Y, Maeda K, Gatanaga H, Weber IT, Mitsuya H. Structure-based design of novel HIV-1 protease inhibitors to combat drug resistance. J Med Chem. 2006;49(17):5252-61.

Goffinet C, Allespach I, Homann S, Tervo HM, Habermann A, Rupp D, Oberbremer L, Kern C, Tibroni N, Welsch S, Krijnse-Locker J , Banting G, Krausslich HG, Fackler OT, Keppler OT. HIV-1 antagonism of CD317 is species specific and involves Vpumediated proteasomal degradation of the restriction factor. Cell Host Microbe. 2009;5(3):285-97.

Goila-Gaur R, Strebel K. HIV-1 Vif, APOBEC, and intrinsic immunity. Retrovirology. 2008;5:51.

Gonzalez-Alba J M, Holguin A, Garcia R, Garcia-Bujalance S, Alonso R, Suarez A, Delgado R, Cardenoso L, Gonzalez R, Garcia-Bermejo I, Portero F, de Mendoza C, Gonzalez-Candelas F, Galan J C. Molecular surveillance of HIV-1 in Madrid, Spain: a phylogeographic analysis. J Virol. 2011;85(20):10755-63.

Gottlieb MS, Schroff R, Schanker HM, Weisman JD, Fan PT, Wolf RA, Saxon A. Pneumocystis carinii pneumonia and mucosal candidiasis in previously healthy homosexual men: evidence of a new acquired cellular immunodeficiency. $\mathrm{N}$ Engl J Med. 1981;305(24): 1425-31.

Gratton S, Cheynier R, Dumaurier M-J, Oksenhendler E, Wain-Hobson S. Highly restricted spread of HIV-1 and multiply infected cells within splenic germinal centers. Proceedings of the National Academy of Sciences. 2000;97(26):14566-71.

Grmek MD, Maulitz RC, Duffin J . History of AIDS: emergence and origin of a modern pandemic. NewJ ersey: Princeton University Press; 1993.

Grossman Z, Polis M, Feinberg MB, Levi I, Jankelevich S, Yarchoan R, Boon J, de Wolf F, Lange J M, Goudsmit J, Dimitrov DS, Paul WE. Ongoing HIV dissemination during HAART. Nat Med. 1999;5(10):1099-104.

Guimaraes ML, Couto-Fernandez JC, Eyer-Silva Wde A, Teixeira SL, ChequerFernandez SL, Morgado MG. Analysis of HIV-1 BF pr/rt recombinant strains from Rio de J aneiro/ Brazil reveals multiple unrelated mosaic structures. Infect Genet Evol. 2010;10(7):1094-100.

Guimaraes ML, Eyer-Silva WA, Couto-Fernandez J C, Morgado MG. Identification of two new CRF_BF in Rio de J aneiro State, Brazil. AIDS. 2008;22(3):433-5.

Guimaraes ML, Velarde-Dunois KG, Segurondo D, Morgado MG. The HIV-1 epidemic in Bolivia is dominated by subtype B and CRF12_BF "family" strains. Virol J. 2012;9:19.

Guo F, Cen S, Niu M, Saadatmand J, Kleiman L. Inhibition of tRNA3Lys-primed reverse transcription by human APOBEC3G during human immunodeficiency virus type 1 replication. J Virol. 2006;80(23):11710-22. 
Hang J Q, Li Y, Yang Y, Cammack N, Mirzadegan T, Klumpp K. Substrate-dependent inhibition or stimulation of HIV RNase $\mathrm{H}$ activity by non-nucleoside reverse transcriptase inhibitors (NNRTIs). Biochem Biophys Res Commun. 2007;352(2):34150.

Hansson T, Aqvist J. Estimation of binding free energies for HIV proteinase inhibitors by molecular dynamics simulations. Protein Eng. 1995;8(11):1137-44.

Hansson T, Marelius J, Aqvist J. Ligand binding affinity prediction by linear interaction energy methods. J Comput Aided Mol Des. 1998;12(1):27-35.

Hare S, Gupta SS, Valkov E, Engelman A, Cherepanov P. Retroviral intasome assembly and inhibition of DNA strand transfer. Nature. 2010;464(7286):232-6.

Harro CD, Judson FN, Gorse GJ, Mayer KH, Kostman J R, Brown SJ, Koblin B, Marmor M, Bartholow BN, Popovic V. Recruitment and baseline epidemiologic profile of participants in the first phase $3 \mathrm{HIV}$ vaccine efficacy trial. J Acquir Immune Defic Syndr. 2004;37(3):1385-92.

Harte WE, J r., Swaminathan S, Beveridge DL. Molecular dynamics of HIV-1 protease. Proteins. 1992;13(3):175-94.

Hartl DL, Clark AG. Principles of population genetics. 2nd ed. Sunderland, Mass.: Sinauer Associates; 1989.

Havlir DV, Eastman S, Gamst A, Richman DD. Nevirapine-resistant human immunodeficiency virus: kinetics of replication and estimated prevalence in untreated patients. J Virol. 1996;70(11):7894-9.

Heal JW, Jimenez-Roldan JE, Wells SA, Freedman RB, Romer RA. Inhibition of HIV-1 protease: the rigidity perspective. Bioinformatics. 2012;28(3):350-7.

Hennig W. Phylogenetic systematics: University of Illinois Press, Urbana; 1966.

Hess B, Bekker H, Berendsen HJ C, Fraaije J GEM. LINCS: A linear constraint solver for molecular simulations. J Comput Chem. 1997;18(12):1463-72.

Heyndrickx L, Alary M, Janssens W, Davo N, van der Groen G. HIV-1 group O and group M dual infection in Benin. Lancet. 1996;347(9005):902-3.

Hierholzer J , Montano S, Hoelscher M, Negrete M, Hierholzer M, Avila MM, Carrillo MG, Russi J C, Vinoles J, Alava A, Acosta ME, Gianella A, Andrade R, Sanchez J L, Carrion G, Russell K, Robb M, Birx D, McCutchan F, Carr JK. Molecular Epidemiology of HIV Type 1 in Ecuador, Peru, Bolivia, Uruguay, and Argentina. AIDS Res Hum Retroviruses. 2002;18(18):1339-50.

Hirsch VM, Olmsted RA, Murphey-Corb M, Purcell RH, Johnson PR. An African primate lentivirus (SIVsm) closely related to HIV-2. Nature. 1989;339(6223):389-92.

Ho DD. Time to hit HIV, early and hard. N Engl J Med. 1995;333(7):450-1. 
Ho DD, Moudgil T, Alam M. Quantitation of human immunodeficiency virus type 1 in the blood of infected persons. N Engl J Med. 1989;321(24):1621-5.

Ho DD, Neumann AU, Perelson AS, Chen W, Leonard JM, Markowitz M. Rapid turnover of plasma virions and CD4 lymphocytes in HIV-1 infection. Nature. 1995;373(6510):123-6.

Hockney RW, Eastwood. Computer simulation using particles: MacGraw-Hill; 1981.

Hornak V, Okur A, Rizzo RC, Simmerling C. HIV-1 protease flaps spontaneously open and reclose in molecular dynamics simulations. Proc Natl Acad Sci U S A. 2006;103(4):915-20.

Hou T, McLaughlin WA, Wang W. Evaluating the potency of HIV-1 protease drugs to combat resistance. Proteins. 2008;71(3):1163-74.

Hou T, Zhang W, Wang J, Wang W. Predicting drug resistance of the HIV-1 protease using molecular interaction energy components. Proteins. 2009;74(4):837-46.

Hu WS, Temin HM. Genetic consequences of packaging two RNA genomes in one retroviral particle: pseudodiploidy and high rate of genetic recombination. Proc Natl Acad Sci U S A. 1990;87(4):1556-60.

Huang H, Chopra R, Verdine GL, Harrison SC. Structure of a covalently trapped catalytic complex of HIV-1 reverse transcriptase: implications for drug resistance. Science. 1998;282(5394):1669-75.

Huelsenbeck JP. The robustness of two phylogenetic methods: four-taxon simulations reveal a slight superiority of maximum likelihood over neighbor joining. Mol Biol Evol. 1995;12(5):843-9.

Hughes GJ , Fearnhill E, Dunn D, Lycett SJ , Rambaut A, Leigh Brown AJ. Molecular phylodynamics of the heterosexual HIV epidemic in the United Kingdom. PLoS Pathog. 2009;5(9):e1000590.

Humphrey W, Dalke A, Schulten K. VMD: visual molecular dynamics. J Mol Graph. 1996;14(1):33-8, 27-8.

Iamarino A, de Melo FL, Braconi CT, Zanotto PM. BF Integrase Genes of HIV-1 Circulating in Sao Paulo, Brazil, with a Recurrent Recombination Region. Plos One. 2012; 7(4):e34324.

J anini LM, Pieniazek D, Peralta J M, Schechter M, Tanuri A, Vicente ACP, Torre ND, Pieniazek NJ, Luo C-C, Kalish ML, Schochetman G, Rayfield MA. Identification of single and dual infections with distinct subtypes of human immunodeficiency virus type 1 by using restriction fragment length polymorphism analysis. Virus Genes. 1996;13(1):69-81.

Janini LM, Tanuri A, Schechter M, Peralta J M, Vicente ACP, Torre ND, Pieniazek NJ, Luo C-c, Ramos A, Soriano V, Schochetman G, Rayfield MA, Pieniazek D. Horizontal 
and Vertical Transmission of Human Immunodeficiency Virus Type 1 Dual Infections Caused by Viruses of Subtypes B and C. The Journal of Infectious Diseases. 1998;177(1):227-31.

J armuz A, Chester A, Bayliss J, Gisbourne J , Dunham I, Scott J , Navaratnam N. An anthropoid-specific locus of orphan C to U RNA-editing enzymes on chromosome 22. Genomics. 2002;79(3):285-96.

Johnson WE, Sawyer SL. Molecular evolution of the antiretroviral TRIM5 gene. Immunogenetics. 2009;61(3):163-76.

J oint United Nations Programme on HIV/ AIDS WHO. Report on the global AIDS epidemic. 2010 [2012 Mar 05]; Available at: http:// www.unaids.org.

Jorgensen WL, Tirado-Rives J. The OPLS [optimized potentials for liquid simulations] potential functions for proteins, energy minimizations for crystals of cyclic peptides and crambin. J Am Chem Soc. 1988;110(6):1657-66.

J ouvenet N, Bieniasz PD, Simon SM. Imaging the biogenesis of individual HIV-1 virions in live cells. Nature. 2008;454(7201):236-40.

J ouvenet N, Neil SJ D, Bess C, Johnson MC, Virgen CA, Simon SM, Bieniasz PD. Plasma membrane is the site of productive HIV-1 particle assembly. Plos Biol. 2006;4(12):2296-310.

J ung A, Maier R, Vartanian J-P, Bocharov G, Jung V, Fischer U, Meese E, WainHobson S, Meyerhans A. Recombination: Multiply infected spleen cells in HIV patients. Nature. 2002;418(6894): 144.

Kaldor SW, Kalish VJ , Davies J F, 2nd, Shetty BV, Fritz JE, Appelt K, Burgess JA, Campanale KM, Chirgadze NY, Clawson DK, Dressman BA, Hatch SD, Khalil DA, Kosa MB, Lubbehusen PP, Muesing MA, Patick AK, Reich SH, Su KS, Tatlock JH. Viracept (nelfinavir mesylate, AG1343): a potent, orally bioavailable inhibitor of HIV1 protease. J Med Chem. 1997;40(24):3979-85.

Kaletsky RL, Francica J R, Agrawal-Gamse C, Bates P. Tetherin-mediated restriction of filovirus budding is antagonized by the Ebola glycoprotein. Proc Natl Acad Sci U S A. $2009 ; 106(8): 2886-91$.

Kalra P, Reddy TV, Jayaram B. Free energy component analysis for drug design: a case study of HIV-1 protease-inhibitor binding. J Med Chem. 2001;44(25):4325-38.

Kantor R, Katzenstein DA, Efron B, Carvalho AP, Wynhoven B, Cane P, Clarke J, Sirivichayakul S, Soares MA, Snoeck J , Pillay C, Rudich H, Rodrigues R, Holguin A, Ariyoshi K, Bouzas MB, Cahn P, Sugiura W, Soriano V, Brigido LF, Grossman Z, Morris L, Vandamme AM, Tanuri A, Phanuphak P, Weber J N, Pillay D, Harrigan PR, Camacho R, Schapiro J M, Shafer RW. Impact of HIV-1 subtype and antiretroviral therapy on protease and reverse transcriptase genotype: results of a global collaboration. PLoS Med. 2005;2(4):e112. 
Katoh E, Louis J M, Yamazaki T, Gronenborn AM, Torchia DA, Ishima R. A solution NMR study of the binding kinetics and the internal dynamics of an HIV-1 proteasesubstrate complex. Protein Sci. 2003;12(7):1376-85.

Klarmann GJ, Schauber CA, Preston BD. Template-directed pausing of DNA synthesis by HIV-1 reverse transcriptase during polymerization of HIV-1 sequences in vitro. J Biol Chem. 1993;268(13):9793-802.

Kohlstaedt LA, Wang J , Friedman J M, Rice PA, Steitz TA. Crystal structure at 3.5 A resolution of HIV-1 reverse transcriptase complexed with an inhibitor. Science. 1992;256(5065):1783-90.

Kondo E, Mammano F, Cohen EA, Gottlinger HG. The p6gag domain of human immunodeficiency virus type 1 is sufficient for the incorporation of Vpr into heterologous viral particles. J Virol. 1995;69(5):2759-64.

Kornberg A. DNA replication. New York: W.H. Freeman; 1982.

Kozisek M, Bray J, Rezacova P, Saskova K, Brynda J, Pokorna J, Mammano F, Rulisek L, Konvalinka J. Molecular analysis of the HIV-1 resistance development: enzymatic activities, crystal structures, and thermodynamics of nelfinavir-resistant HIV protease mutants. J Mol Biol. 2007;374(4):1005-16.

Krauchenco S, Martins NH, Sanches M, Polikarpov I. Effectiveness of commercial inhibitors against subtype F HIV-1 protease. J Enzyme Inhib Med Chem. 2009;24(3):638-45.

Krieger E, Nabuurs SB, Vriend G. Homology Modeling. Structural Bioinformatics. NewJ ersey: J ohn Wiley \& Sons, Inc.; 2005. p. 509-23.

Krishnan L, Li X, Naraharisetty HL, Hare S, Cherepanov P, Engelman A. Structurebased modeling of the functional HIV-1 intasome and its inhibition. Proc Natl Acad Sci U S A. 2010;107(36):15910-5.

Kuhner MK, Felsenstein J. A simulation comparison of phylogeny algorithms under equal and unequal evolutionary rates. Mol Biol Evol. 1994;11(3):459-68.

Kuntz ID. Structure-based strategies for drug design and discovery. Science. 1992;257(5073):1078-82.

Lal RB, Chakrabarti S, Yang C. Impact of genetic diversity of HIV-1 on diagnosis, antiretroviral therapy \& vaccine development. Indian J Med Res. 2005;121(4):287314.

Larder BA, Darby G, Richman DD. HIV with reduced sensitivity to zidovudine (AZT) isolated during prolonged therapy. Science. 1989;243(4899):1731-4.

Larkin MA, Blackshields G, Brown NP, Chenna R, McGettigan PA, McWilliam H, Valentin F, Wallace IM, Wilm A, Lopez R, Thompson JD, Gibson TJ, Higgins DG. Clustal W and Clustal X version 2.0. Bioinformatics. 2007;23(21):2947-8. 
Laskowski RA, MacArthur MW, Moss DS, Thornton J M. PROCHECK: a program to check the stereochemical quality of protein structures. Journal of Applied Crystallography. 1993;26(2):283-91.

Laskowski RA, Rullmannn JA, MacArthur MW, Kaptein R, Thornton J M. AQUA and PROCHECK-NMR: programs for checking the quality of protein structures solved by NMR. J Biomol NMR. 1996;8(4):477-86.

Lavreys L, Baeten JM, Chohan V, McClelland RS, Hassan WM, Richardson BA, Mandaliya K, Ndinya-Achola J O, Overbaugh J . Higher set point plasma viral load and more-severe acute HIV type 1 (HIV-1) illness predict mortality among high-risk HIV1-infected African women. Clin Infect Dis. 2006;42(9):1333-9.

Le Rouzic E, Benichou S. The Vpr protein from HIV-1: distinct roles along the viral life cycle. Retrovirology. 2005;2:11.

Leach AR. Molecular modelling: principles and applications. New J ersey: Prentice Hall; 2001.

Leal, Eacute, lcio, Martins LO, J anini LM, Diaz RS. Evolutionary dynamics of HIV-1 $\mathrm{BF}$ and $\mathrm{CB}$ recombinants and its parental counterparts in South America. Retrovirology: Research and Treatment. 2008;1:1-14.

Ledergerber B, Egger M, Opravil M, Telenti A, Hirschel B, Battegay M, Vernazza P, Sudre P, Flepp M, Furrer H, Francioli P, Weber R. Clinical progression and virological failure on highly active antiretroviral therapy in HIV-1 patients: a prospective cohort study. Swiss HIV Cohort Study. Lancet. 1999;353(9156):863-8.

Lee K, Ambrose Z, Martin TD, Oztop I, Mulky A, Julias J G, Vandegraaff N, Baumann J G, Wang R, Yuen W, Takemura T, Shelton K, Taniuchi I, Li Y, Sodroski J , Littman DR, Coffin J M, Hughes SH, Unutmaz D, Engelman A, KewalRamani VN. Flexible use of nuclear import pathways by HIV-1. Cell Host Microbe. 2010;7(3):221-33.

Lehmann-Che J, Saib A. Early stages of HIV replication: how to hijack cellular functions for a successful infection. AIDS Rev. 2004;6(4):199-207.

Lewis F, Hughes GJ, Rambaut A, Pozniak A, Leigh Brown AJ. Episodic sexual transmission of HIV revealed by molecular phylodynamics. PLoS Med. 2008;5(3):e50.

Li S, Hill CP, Sundquist WI, Finch JT. Image reconstructions of helical assemblies of the HIV-1 CA protein. Nature. 2000a;407(6802):409-13.

Li Y, Luo L, Thomas DY, Kang CY. The HIV-1 Env protein signal sequence retards its cleavage and down-regulates the glycoprotein folding. Virology. 2000b;272(2):41728.

Liljeros F, Edling CR, Amaral LA, Stanley HE, Aberg Y. The web of human sexual contacts. Nature. 2001;411(6840):907-8. 
Lisovsky I, Schader SM, Martinez-Cajas J L, Oliveira M, Moisi D, Wainberg MA. HIV1 protease codon 36 polymorphisms and differential development of resistance to nelfinavir, lopinavir, and atazanavir in different HIV-1 subtypes. Antimicrob Agents Chemother. 2010;54(7):2878-85.

Liu H, Wu X, Newman M, Shaw GM, Hahn BH, Kappes J C. The Vif protein of human and simian immunodeficiency viruses is packaged into virions and associates with viral core structures. J Virol. 1995;69(12):7630-8.

Liu R, Paxton WA, Choe S, Ceradini D, Martin SR, Horuk R, MacDonald ME, Stuhlmann H, Koup RA, Landau NR. Homozygous defect in HIV-1 coreceptor accounts for resistance of some multiply-exposed individuals to HIV-1 infection. Cell. 1996;86(3):367-77.

Lole KS, Bollinger RC, Paranjape RS, Gadkari D, Kulkarni SS, Novak NG, Ingersoll R, Sheppard HW, Ray SC. Full-length human immunodeficiency virus type 1 genomes from subtype C-infected seroconverters in India, with evidence of intersubtype recombination. J Virol. 1999;73(1):152-60.

Los Alamos HIV database. [2012 J an 01]; Available at: http:/ / www.hiv.lanl.gov/ .

Louwagie J, Delwart EL, Mullins J I, McCutchan FE, Eddy G, Burke DS. Genetic analysis of HIV-1 isolates from Brazil reveals presence of two distinct genetic subtypes. AIDS Res Hum Retroviruses. 1994;10(5):561-7.

Louwagie J , McCutchan FE, Peeters M, Brennan TP, Sanders-Buell E, Eddy GA, van der Groen G, Fransen K, Gershy-Damet GM, Deleys R, et al. Phylogenetic analysis of gag genes from 70 international HIV-1 isolates provides evidence for multiple genotypes. AIDS. 1993;7(6):769-80.

Loveday C. International perspectives on antiretroviral resistance. Nucleoside reverse transcriptase inhibitor resistance. J Acquir Immune Defic Syndr. 2001;26 Suppl 1:S10-24.

Lu K, Heng X, Summers MF. Structural determinants and mechanism of HIV-1 genome packaging. J Mol Biol. 2011;410(4):609-33.

Lundquist CA, Tobiume M, Zhou J, Unutmaz D, Aiken C. Nef-mediated downregulation of CD4 enhances human immunodeficiency virus type 1 replication in primary T lymphocytes. J Virol. 2002; 76(9):4625-33.

Luo T, Livingston RA, Garcia JV. Infectivity enhancement by human immunodeficiency virus type 1 Nef is independent of its association with a cellular serine/ threonine kinase. J Virol. 1997;71(12):9524-30.

Macia J , Sole RV, Elena SF. The causes of epistasis in genetic networks. Evolution. 2012;66(2):586-96.

Mackerell $\mathrm{AD}$, J r. Empirical force fields for biological macromolecules: overview and issues. J Comput Chem. 2004;25(13):1584-604. 
Maertens GN, Hare S, Cherepanov P. The mechanism of retroviral integration from X-ray structures of its key intermediates. Nature. 2010;468(7321):326-9.

Magadan JG, Perez-Victoria FJ, Sougrat R, Ye Y, Strebel K, Bonifacino JS. Multilayered mechanism of CD4 downregulation by HIV-1 Vpu involving distinct ER retention and ERAD targeting steps. PLoS Pathog. 2010;6(4):e1000869.

Magiorkinis G, Paraskevis D, Vandamme AM, Magiorkinis E, Sypsa V, Hatzakis A. In vivo characteristics of human immunodeficiency virus type 1 intersubtype recombination: determination of hot spots and correlation with sequence similarity. J Gen Virol. 2003;84(Pt 10):2715-22.

Malet I, Roquebert B, Dalban C, Wirden M, Amellal B, Agher R, Simon A, Katlama C, Costagliola D, Calvez V, Marcelin AG. Association of Gag cleavage sites to protease mutations and to virological response in HIV-1 treated patients. J Infect. 2007;54(4):367-74.

Malmberg RL. The evolution of epistasis and the advantage of recombination in populations of bacteriophage T4. Genetics. [Article]. 1977;86(3):607-21.

Mansky LM, Temin HM. Lower in vivo mutation rate of human immunodeficiency virus type 1 than that predicted from the fidelity of purified reverse transcriptase. J Virol. 1995;69(8):5087-94.

Marins J R, Jamal LF, Chen SY, Barros MB, Hudes ES, Barbosa AA, Chequer P, Teixeira PR, Hearst N. Dramatic improvement in survival among adult Brazilian AIDS patients. AIDS. 2003;17(11):1675-82.

Marti-Renom MA, Stuart AC, Fiser A, Sanchez R, Melo F, Sali A. Comparative protein structure modeling of genes and genomes. Annu Rev Biophys Biomol Struct. 2000;29:291-325.

Martin DP, Lemey P, Lott M, Moulton V, Posada D, Lefeuvre P. RDP3: a flexible and fast computer program for analyzing recombination. Bioinformatics. 2010a;26(19):2462-3.

Martin JC, Hitchcock MJ, De Clercq E, Prusoff WH. Early nucleoside reverse transcriptase inhibitors for the treatment of HIV: a brief history of stavudine (D4T) and its comparison with other dideoxynucleosides. Antiviral Res. 2010b;85(1):34-8.

Martinez-Cajas J L, Wainberg MA. Protease inhibitor resistance in HIV-infected patients: molecular and clinical perspectives. Antiviral Res. 2007;76(3):203-21.

Martinez JP, Bocharov G, Ignatovich A, Reiter J, Dittmar MT, Wain-Hobson S, Meyerhans A. Fitness ranking of individual mutants drives patterns of epistatic interactions in HIV-1. Plos One. 2011;6(3):e18375.

Marx J . A virus by any other name. Science. 1985;227(4693):1449-51.

Mattaj IW, Englmeier L. Nucleocytoplasmic transport: the soluble phase. Annu Rev Biochem. 1998;67:265-306. 
Matthews T, Salgo M, Greenberg M, Chung J, DeMasi R, Bolognesi D. Enfuvirtide: the first therapy to inhibit the entry of HIV-1 into host CD4 lymphocytes. Nat Rev Drug Discov. 2004;3(3):215-25.

McCammon JA, Gelin BR, Karplus M. Dynamics of folded proteins. Nature. 1977;267(5612):585-90.

McDonald D, Vodicka MA, Lucero G, Svitkina TM, Borisy GG, Emerman M, Hope TJ . Visualization of the intracellular behavior of HIV in living cells. J Cell Biol. 2002;159(3):441-52.

McKeever BM, Navia MA, Fitzgerald PM, Springer J P, Leu CT, Heimbach J C, Herbert WK, Sigal IS, Darke PL. Crystallization of the aspartylprotease from the human immunodeficiency virus, HIV-1. J Biol Chem. 1989;264(4):1919-21.

Melo FL. Caracterização biológica e molecular de recombinantes naturais de HIV-1. [tese (Doutorado em Microbiologia)]. São Paulo: Instituto de Ciências Biomédicas, Universidade de São Paulo; 2011.

Melo FL, Jamal LD, Zanotto PM. Characterization of primary isolates of HIV-1 CRF28_BF, CRF29_BF and unique BF recombinants circulating in Sao Paulo, Brazil. AIDS Res Hum Retroviruses. 2011:[Epub ahead of print]. Available from: http:/ / online.liebertpub.com/ doi/ abs/ 10.1089/ aid.2011.0123.

Meyer PR, Matsuura SE, Mian AM, So AG, Scott WA. A mechanism of AZT resistance: an increase in nucleotide-dependent primer unblocking by mutant HIV-1 reverse transcriptase. Mol Cell. 1999;4(1):35-43.

Meyer PR, Matsuura SE, So AG, Scott WA. Unblocking of chain-terminated primer by HIV-1 reverse transcriptase through a nucleotide-dependent mechanism. Proc Natl Acad Sci U S A. 1998;95(23):13471-6.

Meyerson NR, Sawyer SL. Two-stepping through time: mammals and viruses. Trends Microbiol. 2011;19(6):286-94.

Miller M, Schneider J, Sathyanarayana BK, Toth MV, Marshall GR, Clawson L, Selk L, Kent SB, Wlodawer A. Structure of complex of synthetic HIV-1 protease with a substrate-based inhibitor at 2.3 A resolution. Science. 1989;246(4934):1149-52.

Miller MD, Farnet CM, Bushman FD. Human immunodeficiency virus type 1 preintegration complexes: studies of organization and composition. J Virol. 1997;71(7):5382-90.

Minin VN, Dorman KS, Fang F, Suchard MA. Dual multiple change-point model leads to more accurate recombination detection. Bioinformatics. 2005;21(13):303442.

Programa Nacional de DST e AIDS. Boletim Epidemiológico Aids e DST Ano VIII $\mathrm{n}^{\circ}$ 01. Brasília. 2011 [Acessado em 2012 Mar 05]. Disponível em: http:// www.aids.gov.br/ . 
Mitsuya $H$, Broder S. Inhibition of the in vitro infectivity and cytopathic effect of human T-lymphotrophic virus type III/lymphadenopathy-associated virus (HTLVIII/LAV) by 2',3'-dideoxynucleosides. Proc Natl Acad Sci U S A. 1986;83(6):1911-5.

Mitsuya H, Weinhold KJ , Furman PA, St Clair MH, Lehrman SN, Gallo RC, Bolognesi D, Barry DW, Broder S. 3'-Azido-3'-deoxythymidine (BW A509U): an antiviral agent that inhibits the infectivity and cytopathic effect of human T-lymphotropic virus type III/lymphadenopathy-associated virus in vitro. Proceedings of the National Academy of Sciences. 1985;82(20):7096-100.

Montagnier L. Historical essay. A history of HIV discovery. Science. 2002;298(5599):1727-8.

Morellet N, Demene H, Teilleux V, Huynh-Dinh T, de Rocquigny H, Fournie-Zaluski MC, Roques BP. Structure of the complex between the HIV-1 nucleocapsid protein NCp7 and the single-stranded pentanucleotide d(ACGCC). J Mol Biol. 1998;283(2):419-34.

Morgado MG, Guimaraes ML, Galvao-Castro B. HIV-1 polymorphism: a challenge for vaccine development - a review. Mem Inst Oswaldo Cruz. 2002;97(2):143-50.

Moutouh L, Corbeil J , Richman DD. Recombination leads to the rapid emergence of HIV-1 dually resistant mutants under selective drug pressure. Proc Natl Acad Sci U S A. 1996;93(12):6106-11.

Nadai Y, Eyzaguirre LM, Constantine NT, Sill AM, Cleghorn F, Blattner WA, Carr J K. Protocol for Nearly Full-Length Sequencing of HIV-1 RNA from Plasma. Plos One. 2008;3(1).

Navia MA, Fitzgerald PM, McKeever BM, Leu CT, Heimbach J C, Herber WK, Sigal IS, Darke PL, Springer J P. Three-dimensional structure of aspartyl protease from human immunodeficiency virus HIV-1. Nature. 1989;337(6208):615-20.

Nei M. Molecular evolutionary genetics. New York: Columbia University Press; 1987.

Neil SJ , Eastman SW, J ouvenet N, Bieniasz PD. HIV-1 Vpu promotes release and prevents endocytosis of nascent retrovirus particles from the plasma membrane. PLoS Pathog. 2006;2(5):e39.

Neil SJ D, Zang T, Bieniasz PD. Tetherin inhibits retrovirus release and is antagonized by HIV-1 Vpu. Nature. 2008;451(7177):425-30.

Newman ME. Spread of epidemic disease on networks. Phys Rev E Stat Nonlin Soft Matter Phys. 2002;66(1 Pt 2):016128.

Neyman J, Pearson ES. On the Problem of the Most Efficient Tests of Statistical Hypotheses. Philosophical Transactions of the Royal Society of London. 1933;231:289-337.

NIH AIDS Research \& Reference Reagent Program, Division of AIDS, NIAID, NIH. 
Nikolenko GN, Svarovskaia ES, Delviks KA, Pathak VK. Antiretroviral drug resistance mutations in human immunodeficiency virus type 1 reverse transcriptase increase template-switching frequency. J Virol. 2004;78(16):8761-70.

Nora T, Charpentier C, Tenaillon O, Hoede C, Clavel F, Hance AJ. Contribution of Recombination to the Evolution of Human Immunodeficiency Viruses Expressing Resistance to Antiretroviral Treatment. J Virol. 2007;81(14):7620-8.

Nunn AS, Fonseca EM, Bastos FI, Gruskin S, Salomon J A. Evolution of antiretroviral drug costs in Brazil in the context of free and universal access to AIDS treatment. PLoS Med. 2007;4(11):e305.

Ode H, Matsuyama S, Hata M, Neya S, Kakizawa J, Sugiura W, Hoshino T. Computational characterization of structural role of the non-active site mutation M36I of human immunodeficiency virus type 1 protease. J Mol Biol. 2007;370(3):598-607.

Ode H, Ota M, Neya S, Hata M, Sugiura W, Hoshino T. Resistant mechanism against nelfinavir of human immunodeficiency virus type 1 proteases. J Phys Chem B. 2005;109(1):565-74.

Onafuwa-Nuga A, Telesnitsky A. The remarkable frequency of human immunodeficiency virus type 1 genetic recombination. Microbiol Mol Biol Rev. 2009;73(3):451-80,

Ostertag W, Roesler G, Krieg CJ, Kind J, Cole T, Crozier T, Gaedicke G, Steinheider G, Kluge N, Dube S. Induction of endogenous virus and of thymidine kinase by bromodeoxyuridine in cell cultures transformed by Friend virus. Proc Natl Acad Sci U S A. 1974;71(12):4980-5.

Ott DE. Cellular proteins detected in HIV-1. Rev Med Virol. 2008;18(3):159-75.

Pai VB, Nahata MC. Nelfinavir mesylate: a protease inhibitor. Ann Pharmacother. 1999;33(3):325-39.

Pardini MI, Jamal LF, Durigon EL, Massad E, Perez J F, Pinho JR, Holmes EC, de Andrade Zanotto PM. Boosting virology in Brazil. Plos Biol. 2008;6(3):e57.

Parera M, Perez-Alvarez N, Clotet B, Martinez MA. Epistasis among deleterious mutations in the HIV-1 protease. J Mol Biol. 2009;392(2):243-50.

Passaes CP, Guimaraes ML, Bello G, Morgado MG. Near full-length genome characterization of HIV type 1 unique BC recombinant forms from Southern Brazil. AIDS Res Hum Retroviruses. 2009;25(12):1339-44.

Pastor-Satorras R, Vespignani A. Epidemic spreading in scale-free networks. Phys Rev Lett. 2001;86(14):3200-3.

Patick AK, Duran M, Cao Y, Shugarts D, Keller MR, Mazabel E, Knowles M, Chapman S, Kuritzkes DR, Markowitz M. Genotypic and phenotypic characterization of human 
immunodeficiency virus type 1 variants isolated from patients treated with the protease inhibitor nelfinavir. Antimicrob Agents Chemother. 1998;42(10):2637-44.

Pearl L, Blundell T. The active site of aspartic proteinases. Febs Lett. 1984;174(1):96101.

Peeters M, Honore C, Huet T, Bedjabaga L, Ossari S, Bussi P, Cooper RW, Delaporte E. Isolation and partial characterization of an HIV-related virus occurring naturally in chimpanzees in Gabon. AIDS. 1989;3(10):625-30.

Perelson AS, Neumann AU, Markowitz M, Leonard J M, Ho DD. HIV-1 dynamics in vivo: virion clearance rate, infected cell life-span, and viral generation time. Science. 1996;271(5255):1582-6.

Perez-Caballero D, Zang T, Ebrahimi A, McNatt MW, Gregory DA, Johnson MC, Bieniasz PD. Tetherin inhibits HIV-1 release by directly tethering virions to cells. Cell. 2009;139(3):499-511.

Permanyer M, Ballana E, Este JA. Endocytosis of HIV: anything goes. Trends Microbiol. 2010;18(12):543-51.

Perrin V, Mammano F. Parameters driving the selection of nelfinavir-resistant human immunodeficiency virus type 1 variants. J Virol. 2003;77(18):10172-5.

Peters S, Munoz M, Yerly S, Sanchez-Merino V, Lopez-Galindez C, Perrin L, Larder B, Cmarko D, Fakan S, Meylan P, Telenti A. Resistance to nucleoside analog reverse transcriptase inhibitors mediated by human immunodeficiency virus type $1 \mathrm{p} 6$ protein. J Virol. 2001;75(20):9644-53.

Petroni A, Deluchi G, Pryluka D, Rotryng F, Bortolozzi R, Lopardo G, Bouzas MB, Zapiola I, Garone D, Rodriguez C, Chiocconi E, Lazaro ME, Murano F, Maranzana A, Oliva SM, Aparicio M, Beltran M, Benetucci J A. Update on primary HIV-1 resistance in Argentina: emergence of mutations conferring high-level resistance to nonnucleoside reverse transcriptase inhibitors in drug-naive patients. J Acquir Immune Defic Syndr. 2006;42(4):506-10.

Pettit SC, Sheng N, Tritch R, Erickson-Viitanen S, Swanstrom R. The regulation of sequential processing of HIV-1 Gag by the viral protease. Adv Exp Med Biol. 1998;436:15-25.

Piana S, Carloni P, Rothlisberger U. Drug resistance in HIV-1 protease: Flexibilityassisted mechanism of compensatory mutations. Protein Sci. 2002;11(10):2393-402.

Piana S, Sebastiani D, Carloni P, Parrinello M. Ab initio molecular dynamics-based assignment of the protonation state of pepstatin A/ HIV-1 protease cleavage site. J Am Chem Soc. 2001;123(36):8730-7.

Piantadosi A, Chohan B, Chohan V, McClelland RS, Overbaugh J . Chronic HIV-1 infection frequently fails to protect against superinfection. PLoS Pathog. 2007;3(11):e177. 
Pieniazek D, Janini LM, Ramos A, Tanuri A, Schechter M, Peralta JM, Vicente AC, Pieniazek NK, Schochetman G, Rayfield MA. HIV-1 patients may harbor viruses of different phylogenetic subtypes: implications for the evolution of the HIV/AIDS pandemic. Emerg Infect Dis. 1995;1(3):86-8.

Pieniazek D, Rayfield M, Hu DJ, Nkengasong J, Wiktor SZ, Downing R, Biryahwaho B, Mastro T, Tanuri A, Soriano V, Lal R, Dondero T. Protease sequences from HIV-1 group $\mathrm{M}$ subtypes A-H reveal distinct amino acid mutation patterns associated with protease resistance in protease inhibitor-naive individuals worldwide. HIV Variant Working Group. AIDS. 2000;14(11):1489-95.

Pierson T, McArthur J, Siliciano RF. Reservoirs for HIV-1: mechanisms for viral persistence in the presence of antiviral immune responses and antiretroviral therapy. Annu Rev Immunol. 2000;18:665-708.

Pierson TC, Doms RW, Pohlmann S. Prospects of HIV-1 entry inhibitors as novel therapeutics. Rev Med Virol. 2004;14(4):255-70.

Piot P, Quinn TC, Taelman H, Feinsod FM, Minlangu KB, Wobin O, Mbendi N, Mazebo P, Ndangi K, Stevens W, et al. Acquired immunodeficiency syndrome in a heterosexual population in Zaire. Lancet. 1984;2(8394):65-9.

Plantier J-C, Leoz M, Dickerson JE, Oliveira FD, Cordonnier F, Lemée V, Damond F, Robertson DL, Simon F. A new human immunodeficiency virus derived from gorillas. Nat Med. 2009:1-2.

Pneumocystis pneumonia--Los Angeles. MMWR Morb Mortal Wkly Rep. 1981;30(21):250-2.

Pollard VW, Malim MH. The HIV-1 Rev protein. Annu Rev Microbiol. 1998;52:491532.

Pond SL, Frost SD, Muse SV. HyPhy: hypothesis testing using phylogenies. Bioinformatics. 2005;21(5):676-9.

Popovic M, Sarngadharan MG, Read E, Gallo RC. Detection, isolation, and continuous production of cytopathic retroviruses (HTLV-III) from patients with AIDS and pre-AIDS. Science. 1984;224(4648):497-500.

Prabu-J eyabalan M, Nalivaika E, Schiffer CA. How does a symmetric dimer recognize an asymmetric substrate? A substrate complex of HIV-1 protease. J Mol Biol. 2000;301(5):1207-20.

Prabu-J eyabalan M, Nalivaika E, Schiffer CA. Substrate shape determines specificity of recognition for HIV-1 protease: analysis of crystal structures of six substrate complexes. Structure. 2002;10(3):369-81.

Preston BD, Poiesz BJ , Loeb LA. Fidelity of HIV-1 reverse transcriptase. Science. 1988;242(4882):1168-71. 
Rambaut A. Se-Al: Sequence aligment editor. 1996 [2007 Jan 01]; Available at: http:// evolve.zoo.ox.ac.uk.

Rambaut A, Drummond AJ. Tracer v1.5. Available from http:// beastbioedacuk/ Tracer. 2007.

Ramirez BC, Simon-Loriere E, Galetto R, Negroni M. Implications of recombination for HIV diversity. Virus Res. 2008;134(1-2):64-73.

Rannala B, Yang Z. Probability distribution of molecular evolutionary trees: a new method of phylogenetic inference. J Mol Evol. 1996;43(3):304-11.

Reitter J N, Means RE, Desrosiers RC. A role for carbohydrates in immune evasion in AIDS. Nat Med. 1998;4(6):679-84.

Rizzuto CD, Wyatt R, Hernandez-Ramos N, Sun Y, Kwong PD, Hendrickson WA, Sodroski J. A conserved HIV gp120 glycoprotein structure involved in chemokine receptor binding. Science. 1998;280(5371):1949-53.

Roberts NA, Martin JA, Kinchington D, Broadhurst AV, CraigJ C, Duncan IB, Galpin SA, Handa BK, Kay J, Krohn A, et al. Rational design of peptide-based HIV proteinase inhibitors. Science. 1990;248(4953):358-61.

Robertson DL, Anderson J P, Bradac JA, Carr JK, Foley B, Funkhouser RK, Gao F, Hahn BH, Kalish ML, Kuiken C, Learn GH, Leitner T, McCutchan F, Osmanov S, Peeters M, Pieniazek D, Salminen M, Sharp PM, Wolinsky S, Korber B. HIV-1 nomenclature proposal. Science. 2000;288(5463):55-6.

Rossi D, Pawlowicz MP, Rangugni V, Singh DZ, Goltzman P, Cymerman P, Vila M, Touze G. The HIV/ AIDS epidemic and changes in injecting drug use in Buenos Aires, Argentina. Cad Saude Publica. 2006;22(4):741-50.

Rost B. Twilight zone of protein sequence alignments. Protein Eng. 1999;12(2):85-94.

Ruchansky D, Casado C, Russi J C, Arbiza J R, Lopez-Galindez C. Identification of a new HIV Type 1 circulating recombinant form (CRF38_BF1) in Uruguay. AIDS Res Hum Retroviruses. 2009;25(3):351-6.

Sa Filho DJ, Sanabani S, Diaz RS, Munerato P, Brunstein A, Fusuma E, Sabino EC, Janini LM. Analysis of full-length human immunodeficiency virus type 1 genome reveals a variable spectrum of subtypes B and f recombinants in Sao Paulo, Brazil. AIDS Res Hum Retroviruses. 2005;21(2):145-51.

Saad J S, Miller J, Tai J, Kim A, Ghanam RH, Summers MF. Structural basis for targeting HIV-1 Gag proteins to the plasma membrane for virus assembly. Proc Natl Acad Sci U S A. 2006;103(30):11364-9.

Sabino EC, Shpaer EG, Morgado MG, Korber BT, Diaz RS, Bongertz V, Cavalcante S, Galvao-Castro B, Mullins JI, Mayer A. Identification of human immunodeficiency virus type 1 envelope genes recombinant between subtypes $B$ and $F$ in two epidemiologically linked individuals from Brazil. J Virol. 1994;68(10):6340-6. 
Sagui C, Darden TA. Molecular dynamics simulations of biomolecules: long-range electrostatic effects. Annu Rev Biophys Biomol Struct. 1999;28:155-79.

Sali A, Blundell TL. Comparative protein modelling by satisfaction of spatial restraints. J Mol Biol. 1993;234(3):779-815.

Salminen M, Martin D. Detecting and characterizing individual recombination events. In: Salemi M, Vandamme A-M, Lemey P, editors. The phylogenetic handbook: a practical approach to phylogenetic analysis and hypothesis testing. Cambridge, UK ; New York: Cambridge University Press; 2009. p. 519-48.

Salminen MO, Carr JK, Burke DS, McCutchan FE. Identification of breakpoints in intergenotypic recombinants of HIV type 1 by bootscanning. AIDS Res Hum Retroviruses. 1995;11(11):1423-5.

Sanabani S, Kleine Neto W, Kalmar EM, Diaz RS, J anini LM, Sabino EC. Analysis of the near full length genomes of HIV-1 subtypes B, F and BF recombinant from a cohort of 14 patients in Sao Paulo, Brazil. Infect Genet Evol. 2006;6(5):368-77.

Sanabani SS, Pastena ER, Neto WK, Martinez VP, Sabino EC. Characterization and frequency of a newly identified HIV-1 BF1 intersubtype circulating recombinant form in Sao Paulo, Brazil. Virol J. 2010; 7:74.

Sanches M, Krauchenco S, Martins N, Gustchina A, Wlodawer A, Polikarpov I. Structural characterization of B and non-B subtypes of HIV-protease: insights into the natural susceptibility to drug resistance development. J Mol Biol. 2007a;369(4):1029-40.

Sanches M, Krauchenco S, Martins NH, Gustchina A, Wlodawer A, Polikarpov I. Structural characterization of B and non-B subtypes of HIV-protease: insights into the natural susceptibility to drug resistance development. J Mol Biol. 2007b;369(4):1029-40.

Sander C, Schneider R. Database of homology-derived protein structures and the structural meaning of sequence alignment. Proteins. 1991;9(1):56-68.

Sawyer S. Statistical Tests for Detecting Gene Conversion. Mol Biol Evol. 1989;6(5):526-38.

Schlick T. Molecular modeling and simulation: an interdisciplinary guide. New York: Springer; 2010.

Schreiber H, Steinhauser O. Taming cut-off induced artifacts in molecular dynamics studies of solvated polypeptides. The reaction field method. J Mol Biol. 1992;228(3):909-23.

Schultz AK, Zhang M, Bulla I, Leitner T, Korber B, Morgenstern B, Stanke M. jpHMM: Improving the reliability of recombination prediction in HIV-1. Nucleic Acids Research. 2009;37:W647-W51. 
Schultz AK, Zhang M, Leitner T, Kuiken C, Korber B, Morgenstern B, Stanke M. A jumping profile Hidden Markov Model and applications to recombination sites in HIV and HCV genomes. BMC Bioinformatics. 2006; 7:265.

Schupbach J, Popovic M, Gilden RV, Gonda MA, Sarngadharan MG, Gallo RC. Serological analysis of a subgroup of human T-lymphotropic retroviruses (HTLV-III) associated with AIDS. Science. 1984;224(4648):503-5.

Schwartz O, Marechal V, Le Gall S, Lemonnier F, Heard J M. Endocytosis of major histocompatibility complex class I molecules is induced by the HIV-1 Nef protein. Nat Med. 1996;2(3):338-42.

Scott WR, Schiffer CA. Curling of flap tips in HIV-1 protease as a mechanism for substrate entry and tolerance of drug resistance. Structure. 2000;8(12):1259-65.

Scott WRP, Hünenberger PH, Tironi IG, Mark AE, Billeter SR, Fennen J , Torda AE, Huber T, Krüger P, van Gunsteren WF. The GROMOS Biomolecular Simulation Program Package. J Phys Chem A. 1999;103(19):3596-607.

Seelamgari A, Maddukuri A, Berro R, de la Fuente C, Kehn K, Deng L, Dadgar S, Bottazzi ME, Ghedin E, Pumfery A, Kashanchi F. Role of viral regulatory and accessory proteins in HIV-1 replication. Front Biosci. 2004;9:2388-413.

Seelmeier S, Schmidt H, Turk V, von der Helm K. Human immunodeficiency virus has an aspartic-type protease that can be inhibited by pepstatin A. Proc Natl Acad Sci U S A. 1988;85(18):6612-6.

Seibold SA, Cukier RI. A molecular dynamics study comparing a wild-type with a multiple drug resistant HIV protease: Differences in flap and aspartate 25 cavity dimensions. Proteins. 2007;69(3):551-65.

Shafer RW. Genotypic testing for human immunodeficiency virus type 1 drug resistance. Clin Microbiol Rev. 2002;15(2):247-77.

Shafer RW, Kantor R, Gonzales MJ . The Genetic Basis of HIV-1 Resistance to Reverse Transcriptase and Protease Inhibitors. AIDS Rev. 2000;2(4):211-28.

Shafer RW, Schapiro J M. HIV-1 drug resistance mutations: an updated framework for the second decade of HAART. AIDS Rev. 2008;10(2):67-84.

Sharp PM, Bailes E, Chaudhuri RR, Rodenburg CM, Santiago MO, Hahn BH. The origins of acquired immune deficiency syndrome viruses: where and when? Philos Trans R Soc Lond B Biol Sci. 2001;356(1410):867-76.

Sharp PM, Hahn BH. AIDS: prehistory of HIV-1. Nature. 2008;455(7213):605-6.

Sheehy AM, Gaddis NC, Choi J D, Malim MH. Isolation of a human gene that inhibits HIV-1 infection and is suppressed by the viral Vif protein. Nature. 2002;418(6898):646-50. 
Shoichet BK, Kuntz ID. Matching chemistry and shape in molecular docking. Protein Eng. 1993;6(7):723-32.

Sierra M, Thomson MM, Ríos M, Casado G, Castro RO-d, Delgado E, Echevarría G, Muñoz M, Colomina J, Carmona R, Vega Y, Parga EV-d, Medrano L, Pérez-Alvarez L, Contreras G, Nájera R. The analysis of near full-length genome sequences of human immunodeficiency virus type $1 \mathrm{BF}$ intersubtype recombinant viruses from Chile, Venezuela and Spain reveals their relationship to diverse lineages of recombinant viruses related to CRF12 BF. Infect Genet Evol. 2005;5(3):209-17.

Sigal A, Kim JT, Balazs AB, Dekel E, Mayo A, Milo R, Baltimore D. Cell-to-cell spread of HIV permits ongoing replication despite antiretroviral therapy. Nature. 2011;477(7362):95-8.

Silva AWSd. Estudo por modelagem e dinâmica molecular da protease de variantes do Vírus da Imunodeficiência Humana Tipo 1 resistentes a drogas antivirais [tese (Doutorado em Ciências da Saúde)]. Rio de J aneiro: Centro de Ciências da Saúde Instituto de Biofísica Carlos Chagas Filho, Universidade Federal do Rio de J aneiro; 2003.

Simmons A, Aluvihare V, McMichael A. Nef triggers a transcriptional program in T cells imitating single-signal T cell activation and inducing HIV virulence mediators. Immunity. 2001;14(6):763-77.

Simon-Loriere E, Holmes EC. Why do RNA viruses recombine? Nat Rev Micro. 2011;9(8):617-26.

Smith DM, Richman DD, Little SJ. HIV superinfection. J Infect Dis. 2005; 192(3):438-44.

Smith DM, Wong J K, Hightower GK, Ignacio CC, Koelsch KK, Daar ES, Richman DD, Little SJ. Incidence of HIV superinfection following primary infection. JAMA. 2004;292(10):1177-8.

Smith PE, Vangunsteren WF. Consistent Dielectric-Properties of the Simple PointCharge and Extended Simple Point-Charge Water Models at 277 and 300 K. J Chem Phys. 1994;100(4):3169-74.

Soriano V, Mendoza Cd. Genetic mechanisms of resistance to protease inhibitors and entry inhibitors. HIV Clinical Trials. 2002;3(3):249-57.

Steel MA, Hendy MD, Penny D. Loss of information in genetic distances. Nature. 1988;336(6195):118.

Steinbach PJ, Brooks BR. New spherical-cutoff methods for long-range forces in macromolecular simulation. J Comput Chem. 1994;15(7):667-83.

Stjernschantz E, Marelius J, Medina C, J acobsson M, Vermeulen NP, Oostenbrink C. Are automated molecular dynamics simulations and binding free energy calculations realistic tools in lead optimization? An evaluation of the linear interaction energy (LIE) method. J Chem Inf Model. 2006;46(5):1972-83. 
Strebel K. Virus-host interactions: role of HIV proteins Vif, Tat, and Rev. AIDS. 2003; 17 Suppl 4:S25-34.

Streeck H, Li B, Poon AF, Schneidewind A, Gladden AD, Power KA, Daskalakis D, Bazner S, Zuniga R, Brander C, Rosenberg ES, Frost SD, Altfeld M, Allen TM. Immune-driven recombination and loss of control after HIV superinfection. J Exp Med. 2008;205(8):1789-96.

Stremlau M, Perron M, Lee M, Li Y, Song B, J avanbakht H, Diaz-Griffero F, Anderson DJ, Sundquist WI, Sodroski J. Specific recognition and accelerated uncoating of retroviral capsids by the TRIM5alpha restriction factor. Proc Natl Acad Sci U S A. 2006;103(14):5514-9.

Stuhlmann H, Berg P. Homologous recombination of copackaged retrovirus RNAs during reverse transcription. J Virol. 1992;66(4):2378-88.

Suchard MA, Weiss RE, Dorman KS, Sinsheimer J S. Oh brother, where art thou? A Bayes factor test for recombination with uncertain heritage. Syst Biol. 2002;51(5):715-28.

Sucupira MC, Caseiro MM, Alves K, Tescarollo G, Janini LM, Sabino EC, Castelo A, Page-Shafer K, Diaz RS. High levels of primary antiretroviral resistance genotypic mutations and $\mathrm{B} / \mathrm{F}$ recombinants in Santos, Brazil. AIDS Patient Care STDS. 2007a;21(2):116-28.

Sucupira MCA, Caseiro MM, Alves K, Tescarollo G, Janini LM, Sabino EC, Castelo A, Page-Shafer K, Diaz RS. High Levels of Primary Antiretroviral Resistance Genotypic Mutations And B/F Recombinants in Santos, Brazil. AIDS Patient Care STDS. 2007b;21(2):116-28.

Suzuki Y, Craigie R. The road to chromatin - nuclear entry of retroviruses. Nat Rev Microbiol. 2007;5(3):187-96.

Takehisa J, Zekeng L, Miura T, Ido E, Yamashita M, Mboudjeka I, Gurtler LG, Hayami M, Kaptue L. Triple HIV-1 infection with group $\mathrm{O}$ and Group $\mathrm{M}$ of different clades in a single Cameroonian AIDS patient. J Acquir Immune Defic Syndr Hum Retrovirol. 1997;14(1):81-2.

Tamiya S, Mardy S, Kavlick MF, Yoshimura K, Mistuya H. Amino acid insertions near Gag cleavage sites restore the otherwise compromised replication of human immunodeficiency virus type 1 variants resistant to protease inhibitors. J Virol. 2004;78(21):12030-40.

Tanuri A, Swanson P, Devare S, Berro OJ , Savedra A, Costa LJ , Telles J G, Brindeiro R, Schable C, Pieniazek D, Rayfield M. HIV-1 subtypes among blood donors from Rio de J aneiro, Brazil. J Acquir Immune Defic Syndr Hum Retrovirol. 1999;20(1):60-6.

Taube R, Fujinaga K, Wimmer J, Barboric M, Peterlin BM. Tat transactivation: a model for the regulation of eukaryotic transcriptional elongation. Virology. $1999 ; 264(2): 245-53$. 
Tebit DM, Arts EJ. Tracking a century of global expansion and evolution of HIV to drive understanding and to combat disease. Lancet Infect Dis. 2011;11(1):45-56.

Teixeira D, Munerato P, Komninakis SC, Fusuma EE, J anini LM, Sucupira MC, Diaz RS. The detection of in vivo and in vitro HIV type $1 \mathrm{~B} / \mathrm{F}$ profiles in Brazil using a realtime PCR assay for five HIV type 1 genomic regions. AIDS Res Hum Retroviruses. 2010;26(9):981-90.

Teixeira PR, Vitoria MA, Barcarolo J. Antiretroviral treatment in resource-poor settings: the Brazilian experience. AIDS. 2004; 18 Suppl 3:S5-7.

Temin HM. Retrovirus variation and reverse transcription: abnormal strand transfers result in retrovirus genetic variation. Proc Natl Acad Sci U S A. 1993;90(15):6900-3.

Terwilliger EF, Cohen EA, Lu YC, Sodroski JG, Haseltine WA. Functional role of human immunodeficiency virus type $1 \mathrm{vpu}$. Proc Natl Acad Sci U S A. 1989;86(13):5163-7.

Thomson MM, Sierra M, Tanuri A, May S, Casado G, Manjon N, Najera R. Analysis of near full-length genome sequences of HIV type $1 \mathrm{BF}$ intersubtype recombinant viruses from Brazil reveals their independent origins and their lack of relationship to CRF12_BF. AIDS Res Hum Retroviruses. 2004;20(10):1126-33.

Torbeev VY, Raghuraman H, Hamelberg D, Tonelli M, Westler WM, Perozo E, Kent SB. Protein conformational dynamics in the mechanism of HIV-1 protease catalysis. Proc Natl Acad Sci U S A. 2011;108(52):20982-7.

Torbeev VY, Raghuraman H, Mandal K, Senapati S, Perozo E, Kent SB. Dynamics of "flap" structures in three HIV-1 protease/inhibitor complexes probed by total chemical synthesis and pulse-EPR spectroscopy. J Am Chem Soc. 2009;131(3):884-5.

Tripathi A, Fornabaio M, Spyrakis F, Mozzarelli A, Cozzini P, Kellogg GE. Complexity in modeling and understanding protonation states: computational titration of HIV-1protease-inhibitor complexes. Chem Biodivers. 2007;4(11):2564-77.

Tristem M, Purvis A, Quicke DL. Complex evolutionary history of primate lentiviral vpr genes. Virology. 1998;240(2):232-7.

Trylska J, Grochowski P, McCammon JA. The role of hydrogen bonding in the enzymatic reaction catalyzed by HIV-1 protease. Protein Sci. 2004;13(2):513-28.

Turk G, Carobene M, Monczor A, Rubio AE, Gomez-Carrillo M, Salomon H. Higher transactivation activity associated with LTR and Tat elements from HIV-1 BF intersubtype recombinant variants. Retrovirology. 2006;3:14.

UNAIDS/WHO. Report on the global AIDS epidemic. http://wwwunaidsorg. 2010;Acessado em 2012.

Van Damme N, Goff D, Katsura C, J orgenson RL, Mitchell R, J ohnson MC, Stephens EB, Guatelli J. The interferon-induced protein BST-2 restricts HIV-1 release and is 
downregulated from the cell surface by the viral Vpu protein. Cell Host Microbe. 2008;3(4):245-52.

Van Der Spoel D, Lindahl E, Hess B, Groenhof G, Mark AE, Berendsen HJ. GROMACS: fast, flexible, and free. J Comput Chem. 2005;26(16):1701-18.

van Harmelen J , Wood R, Lambrick M, Rybicki EP, Williamson AL, Williamson C. An association between HIV-1 subtypes and mode of transmission in Cape Town, South Africa. AIDS. 1997;11(1):81-7.

Van Heuverswyn F, Li Y, Neel C, Bailes E, Keele BF, Liu W, Loul S, Butel C, Liegeois F, Bienvenue Y, Ngolle EM, Sharp PM, Shaw GM, Delaporte E, Hahn BH, Peeters M. Human immunodeficiency viruses: SIV infection in wild gorillas. Nature. 2006;444(7116):164.

Verheyen J, Litau E, Sing T, Daumer M, Balduin M, Oette M, Fatkenheuer G, Rockstroh JK, Schuldenzucker U, Hoffmann D, Pfister H, Kaiser R. Compensatory mutations at the HIV cleavage sites p7/p1 and p1/p6-gag in therapy-naive and therapy-experienced patients. Antivir Ther. 2006;11(7):879-87.

Vicente AC, Otsuki K, Silva NB, Castilho MC, Barros FS, Pieniazek D, Hu D, Rayfield MA, Bretas G, Tanuri A. The HIV epidemic in the Amazon Basin is driven by prototypic and recombinant HIV-1 subtypes B and F. J Acquir Immune Defic Syndr. 2000;23(4):327-31.

Vijay NNV, Vasantika, Ajmani R, Perelson AS, Dixit NM. Recombination increases human immunodeficiency virus fitness, but not necessarily diversity. J Gen Virol. 2008;89(Pt 6):1467-77.

Visual Science. 2010-2012 [2012 J an 01]; Available at: http://visualscience.ru.

Vivet-Boudou V, Didierjean J, Isel C, Marquet R. Nucleoside and nucleotide inhibitors of HIV-1 replication. Cell Mol Life Sci. 2006;63(2):163-86.

Vogt VM. Proteolytic processing and particle maturation. Curr Top Microbiol Immunol. 1996;214:95-131.

Wang J, Smerdon SJ , Jager J, Kohlstaedt LA, Rice PA, Friedman J M, Steitz TA. Structural basis of asymmetry in the human immunodeficiency virus type 1 reverse transcriptase heterodimer. Proc Natl Acad Sci U SA. 1994;91(15):7242-6.

Wang W, Wang J, Kollman PA. What determines the van der Waals coefficient $\beta$ in the LIE (linear interaction energy) method to estimate binding free energies using molecular dynamics simulations? Proteins: Structure, Function, and Bioinformatics. 1999;34(3):395-402.

Warrilow D, Tachedjian G, Harrich D. Maturation of the HIV reverse transcription complex: putting the jigsaw together. Rev Med Virol. 2009;19(6):324-37.

Warshel A. Molecular dynamics simulations of biological reactions. Acc Chem Res. 2002;35(6):385-95. 
Warshel A, Russell ST. Calculations of electrostatic interactions in biological systems and in solutions. Quarterly Reviews of Biophysics. 1984;17(03):283-422.

Warshel A, Sharma PK, Kato M, Xiang Y, Liu H, Olsson MHM. Electrostatic Basis for Enzyme Catalysis. Chemical Reviews. 2006;106(8):3210-35.

Watts J M, Dang KK, Gorelick RJ, Leonard CW, Bess JW, Jr., Swanstrom R, Burch CL, Weeks KM. Architecture and secondary structure of an entire HIV-1 RNA genome. Nature. 2009;460(7256):711-6.

Wei P, Garber ME, Fang SM, Fischer WH, J ones KA. A novel CDK9-associated C-type cyclin interacts directly with HIV-1 Tat and mediates its high-affinity, loop-specific binding to TAR RNA. Cell. 1998;92(4):451-62.

Wei X, Ghosh SK, Taylor ME, Johnson VA, Emini EA, Deutsch P, Lifson JD, Bonhoeffer S, Nowak MA, Hahn BH, et al. Viral dynamics in human immunodeficiency virus type 1 infection. Nature. 1995;373(6510):117-22.

Weinberg JB, Matthews TJ, Cullen BR, Malim MH. Productive human immunodeficiency virus type 1 (HIV-1) infection of nonproliferating human monocytes. J Exp Med. 1991;174(6):1477-82.

Westby M, van der Ryst E. CCR5 antagonists: host-targeted antivirals for the treatment of HIV infection. Antivir Chem Chemother. 2005;16(6):339-54.

Wilson W, Braddock M, Adams SE, Rathjen PD, Kingsman SM, Kingsman AJ. HIV expression strategies: ribosomal frameshifting is directed by a short sequence in both mammalian and yeast systems. Cell. 1988;55(6):1159-69.

Wittayanarakul K, Hannongbua S, Feig M. Accurate prediction of protonation state as a prerequisite for reliable MM-PB(GB)SA binding free energy calculations of HIV-1 protease inhibitors. J Comput Chem. 2008;29(5):673-85.

Wlodawer A, Erickson JW. Structure-based inhibitors of HIV-1 protease. Annu Rev Biochem. 1993;62:543-85.

Wlodawer A, Miller M, Jaskolski M, Sathyanarayana BK, Baldwin E, Weber IT, Selk LM, Clawson L, Schneider J, Kent SB. Conserved folding in retroviral proteases: crystal structure of a synthetic HIV-1 protease. Science. 1989;245(4918):616-21.

Wlodawer A, Vondrasek J Inhibitors of HIV-1 protease: a major success of structureassisted drug design. Annu Rev Biophys Biomol Struct. 1998;27:249-84.

Wonderlich ER, Williams M, Collins KL. The tyrosine binding pocket in the adaptor protein 1 (AP-1) mu1 subunit is necessary for Nef to recruit AP-1 to the major histocompatibility complex class I cytoplasmic tail. J Biol Chem. 2008;283(6):301122.

$\mathrm{Wu}$ Y. HIV-1 gene expression: lessons from provirus and non-integrated DNA. Retrovirology. 2004;1:13. 
Zanotto PM, Kallas EG, de Souza RF, Holmes EC. Genealogical evidence for positive selection in the nef gene of HIV-1. Genetics. 1999;153(3):1077-89.

Zhang M, Foley B, Schultz AK, Macke J P, Bulla I, Stanke M, Morgenstern B, Korber $\mathrm{B}$, Leitner $\mathrm{T}$. The role of recombination in the emergence of a complex and dynamic HIV epidemic. Retrovirology. 2010;7(1):25.

Zhang Y. Pseudobond ab initio QM/MM approach and its applications to enzyme reactions. Theoretical Chemistry Accounts: Theory, Computation, and Modeling (Theoretica Chimica Acta). 2006;116(1):43-50.

Zhu T, Wang N, Carr A, Wolinsky S, Ho DD. Evidence for coinfection by multiple strains of human immunodeficiency virus type 1 subtype $\mathrm{B}$ in an acute seroconvertor. J Virol. 1995;69(2):1324-7.

Zhuang J , J etzt AE, Sun G, Yu H, Klarmann G, Ron Y, Preston BD, Dougherty JP. Human immunodeficiency virus type 1 recombination: rate, fidelity, and putative hot spots. J Virol. 2002;76(22):11273-82.

Zwickl DJ. Genetic algorithm approaches for the phylogenetic analysis of large biological sequence datasets under the maximum likelihood criterion [Ph.D. thesis]. Austin: The University of Texas; 2006. 
136 ANEXO A - Sequências das proteases modeladas e Atila Iamarino tratamento dos pacientes

\section{ANEXO A - SEQUENCIAS DAS PROTEASES MODELADAS E TRATAMENTO DOS PACIENTES}

$>0063$

PQITLWQRPVVTIKVGGQLKEALLDTGADDTVLEDINLPGKWKPKMIGGIGGFVKV KQYDNILIEICGHKAIGTVLVGPTPVNIIGRNIMTQIGCTLNF

$>0087$

PQITLWQRPLVTIKVGGQLKEALLDTGADDTVLEDINLPGKWKPKLIGGIGGFIKVK QYEDVPIEICGHKAIGTVLVGPTPANIIGRNMLTQIGCTLNF

$>0450$

PQITLWQRPVVKIKVGGQIREALLDTGADDTVLEDINLPGKWKPKMIVGIGGFTKVK QYDNIAIEICGHKAIGSVLVGPTPANIIGRNILTQIGCTLNF

$>0732$

PQITLWQRPLVQIKVGGQLREALLDTGADDTVLEDIELPGKWKPKLIGGIGGFIKVK QYDSILIEICGHKAIGSVLVGPTPANIIGRNMLTQIGCTLNF

$>0449$

PQITLWQRPIVKIKVGGQIIEALLDTGADDTVLEEIELPGRWKPKIIGGIGGFIKVRQY DQIPIEICGMKALSTVLVGPTPVNIIGRNLMTQLGCTLNF

$>0805$

PQITLWKRPIVTIKIGGQLIEALLDTGADDTVLEEIDLPGRWKPKIIGGIGGFVRVKQY EQVPIEICGHKVISTVLVGPTPANIIGRNLMTQIGCTLNF

$>1120$

PQITLWQRPLVTIKIGGQLKEALLDTGADDTVLEEMSLPGRWKPKMIGGIGGFIKVR QYDQILIEICGHKAIGTVLVGPTPVNIIGRNLLTQIGCTLNF

$>1218$

PQITLWQRPFVTIKIGGQLKEALIDTGADDTVFEELNLPGRWKPKLIGGIGGFVRVR EYDQVPIEICGHKVMGTVLVGPTPANIIGRNLLTQIGCTLNF

$>1227$

PQITLWQRPIVTIKVGGQLMEALLDTGADDTVLEDIELPGRWKPKMIVGIGGFTKVK QYDQIPIEICGHKVVGSVLVGPTPANIIGRNLLTQLGCTLNF 
Atila Iamarino ANEXO A - Sequências das proteases modeladas e 137 tratamento dos pacientes

Tabela 1 - Tratamento antirretroviral completo a que os pacientes foram submetidos. (continua)

\begin{tabular}{|c|c|c|c|}
\hline VGDN & ARV & Início & Fim \\
\hline \multirow[t]{3}{*}{0063} & AZT/3TC/IDV & fev-97 & nov-98 \\
\hline & DDI/D4T/RTVISQV & nov-99 & abr-00 \\
\hline & AZT/3TC/NFV & jun-00 & mar-01 \\
\hline \multirow[t]{8}{*}{0087} & $\mathrm{AZT}$ & fev-96 & mar-96 \\
\hline & AZT/DDI & mar-96 & abr-96 \\
\hline & AZT/DDC & jun-96 & nov-96 \\
\hline & AZT/3TC/IDV & nov-96 & fev-98 \\
\hline & 3TC/D4T/SQV/RTV & ago-98 & mai-99 \\
\hline & D4T/3TC/SQV/NFV & mai-99 & jul-99 \\
\hline & D4T/DDI/NFV/IDV & jul-99 & out-99 \\
\hline & D4T/3TC/NFV/IDV & nov-99 & mar-01 \\
\hline \multirow[t]{9}{*}{0450} & $\mathrm{AZT}$ & jan-96 & abr-96 \\
\hline & AZT/DDI & abr-96 & mai-96 \\
\hline & AZT/DDI/SQV & mai-96 & jun-97 \\
\hline & AZT/3TC/SQV & jun-97 & fev-98 \\
\hline & D4T/3TC/IDV & fev-98 & dez-98 \\
\hline & D4T/3TC/IDV/NVP & dez-98 & jun-02 \\
\hline & AZT/DDC/LPV & jun-02 & ago-02 \\
\hline & AZT/DDI/LPV & ago-02 & set-02 \\
\hline & LPV/D4T/DDI & set-02 & ago-03 \\
\hline 0732 & AZT/3TC/NVP & dez-02 & out-03 \\
\hline 0449 & AZT/3TC/NFV & mai-00 & ago-03 \\
\hline \multirow[t]{9}{*}{0805} & $\mathrm{AZT}$ & mar-96 & ago-96 \\
\hline & AZT/DDI & ago-96 & abr-97 \\
\hline & AZT/DDI/SQV & fev-97 & $?$ \\
\hline & 3TC/D4T/NVP/NFV & mai-99 & out-01 \\
\hline & AZT/DDI/IDV/RTV & out-01 & fev-02 \\
\hline & AZT/3TC/IDV/RTV & fev-02 & abr-02 \\
\hline & D4T/3TC/NVP & abr-02 & nov-03 \\
\hline & TDF/3TC/SQV/RTV & nov-03 & jan-04 \\
\hline & TDF/3TC/IDV & jan-04 & ago-04 \\
\hline \multirow[t]{5}{*}{1120} & AZT/DDI & out-96 & ago-97 \\
\hline & AZT/3TC/RTV & ago-97 & jul-98 \\
\hline & 3TC/D4T/IDV & jul-98 & $?$ \\
\hline & 3TC/D4T/IDV & abr-00 & mai-03 \\
\hline & AZT/3TC/EFV & mai-03 & ago-04 \\
\hline \multirow[t]{4}{*}{1218} & AZT/DDI & mai-96 & set-97 \\
\hline & AZT/DDI/RTV & out-97 & set-99 \\
\hline & D4T/3TC/NVP & set-99 & ago-02 \\
\hline & AZT/DDI/LPV/r & dez-03 & mar-04 \\
\hline \multirow[t]{4}{*}{1227} & AZT/DDI & ago-97 & set-97 \\
\hline & AZT/3TC & jan-98 & mai-99 \\
\hline & AZT/DDC & jun-99 & out-99 \\
\hline & AZT/NVP & dez-99 & jan-00 \\
\hline
\end{tabular}


138 ANEXO A - Sequências das proteases modeladas e Atila Iamarino tratamento dos pacientes

\begin{tabular}{cccc} 
VGDN & ARV & Início & Fim \\
\cline { 1 - 3 } & AZT/3TC/NVP & jan-00 & out-00 \\
& D4T/IDV/RTV/NVP & set-01 & mai-04 \\
& 3TC/RTV/TDF/ATV & jun-04 & ago-04 \\
\hline
\end{tabular}

Tratamentos com inibidor de protease com sombreamento em cinza claro, e tratamentos com nelfinavir em cinza escuro. O último tratamento antes da amostragem está em itálico.

PIs:

ATV: atazanavir

IDV: indinavir

LPV: lopinavir

LPVr: lopinavir + ritonavir

NFV: Nelfinavir

RTV: ritonavir

SQV: saquinavir

NRTIs:

AZT: zidovudine

3TC: lamivudine

DDI: didanosine

D4T: stavudine

DDC: zalcitabine

ABC: abacavir

AZT: zidovudine

NtRTIs:

TDF: tenofovir

NNRTIs

NVP: nevirapine

EFV: efavirenz

Fonte: Iamarino (2012). 


\section{ANEXO B - ARQUIVOS DE ENTRADA NA DINÂMICA MOLECULAR}

\section{Comando da minimização energética pelo método de máximo declive com restrição de posição atômica.}

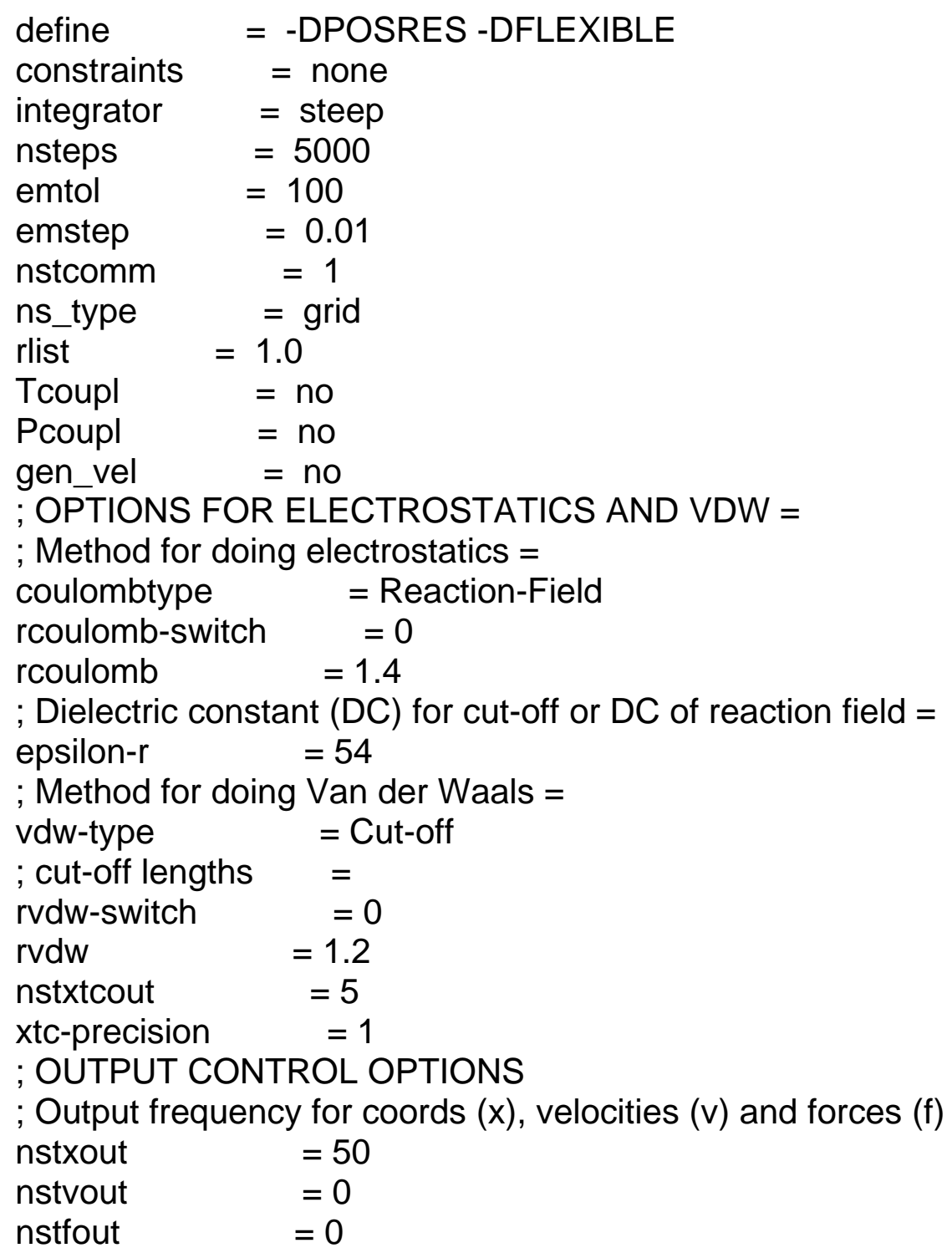


2 Comando da minimização energética pelo método de máximo declive sem restrição de posição atômica.

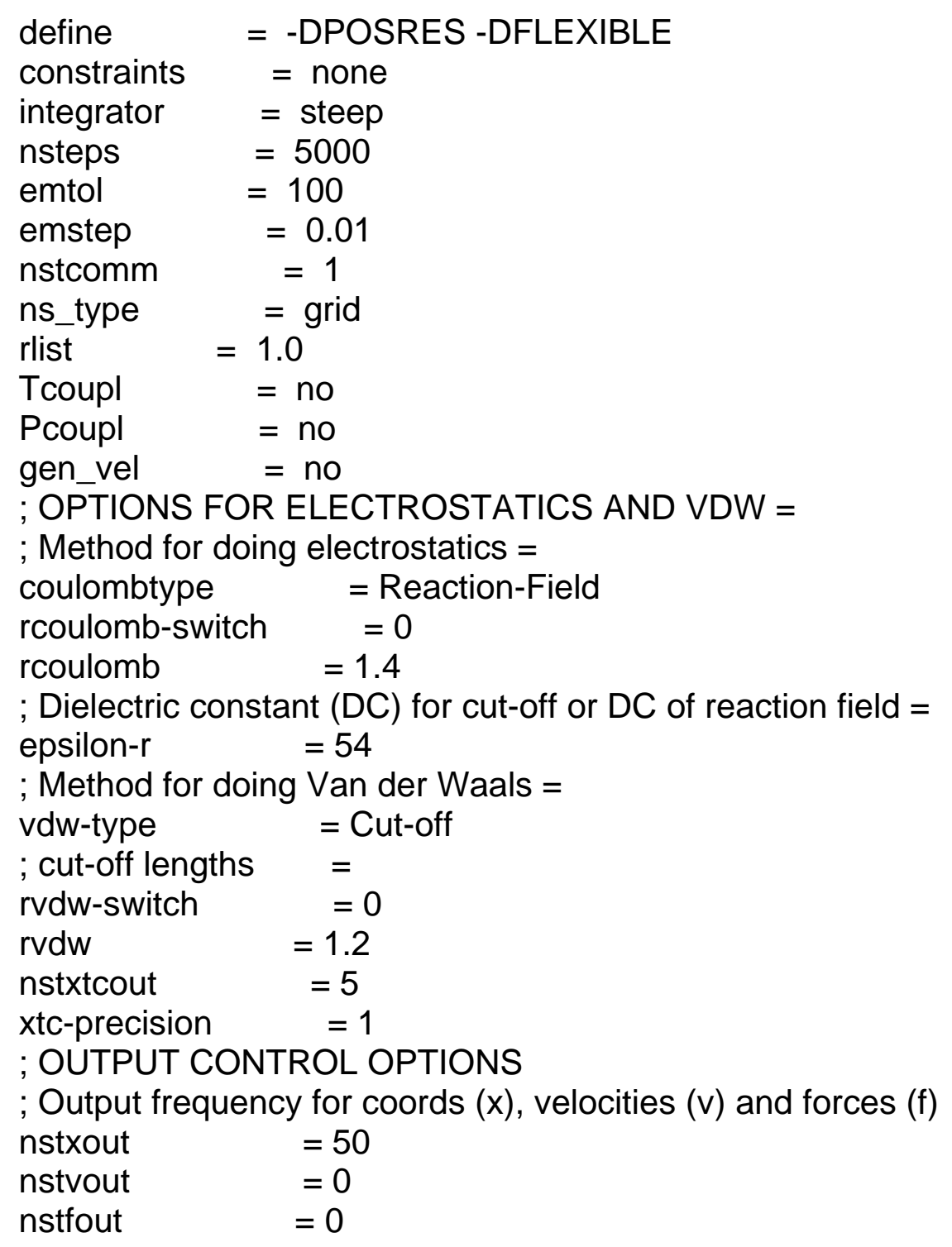




\section{Comando da minimização energética pelo método de gradiente conjugado}
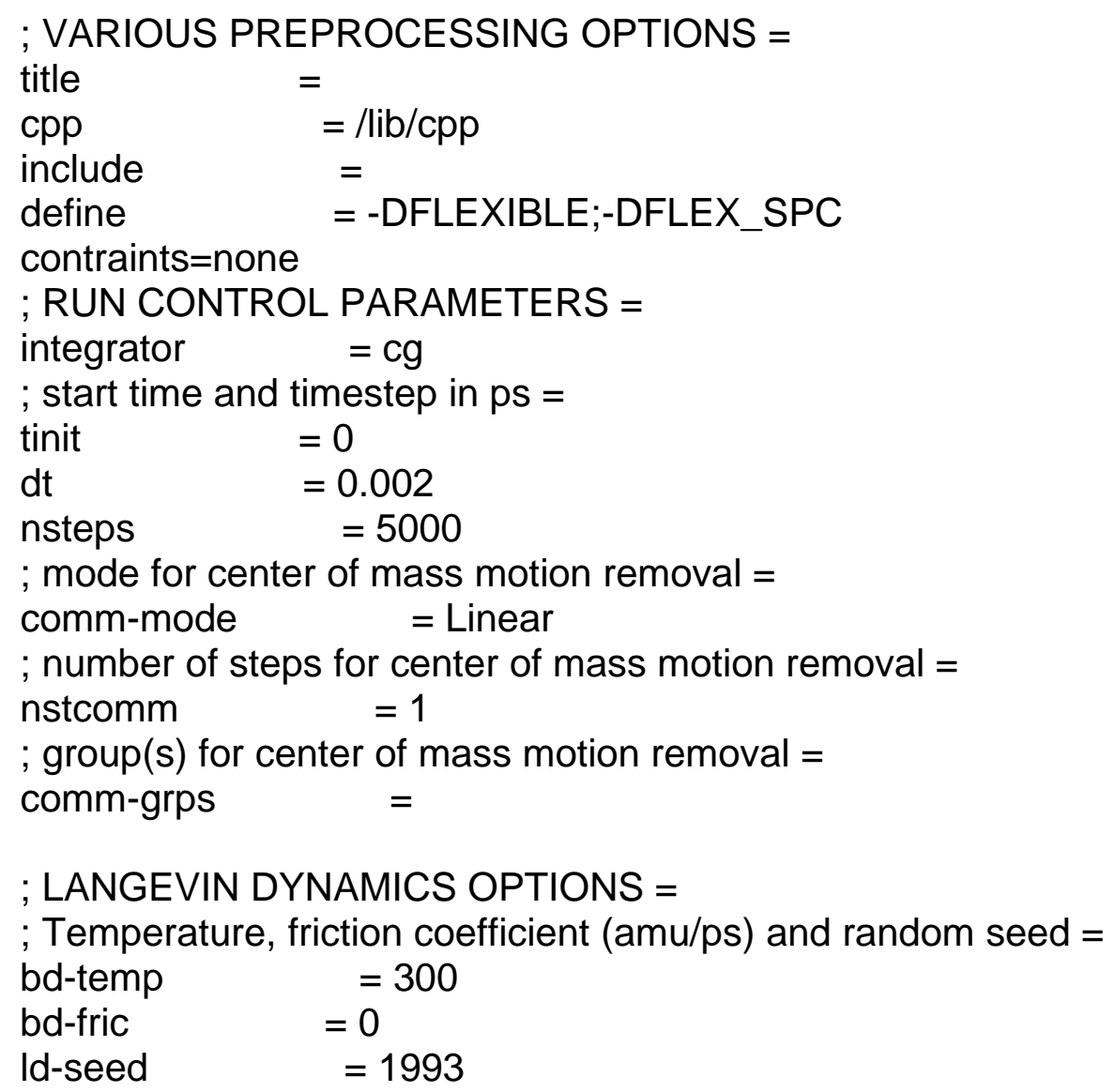

; ENERGY MINIMIZATION OPTIONS =

; Force tolerance and initial step-size $=$

emtol $\quad=42.0$

emstep $\quad=0.01$

; Max number of iterations in relax_shells =

niter $\quad=20$

; Step size $\left(1 / \mathrm{ps}^{\wedge} 2\right)$ for minimization of flexible constraints =

fcstep $\quad=0$

; Frequency of steepest descents steps when doing CG =

nstcgsteep = 1000

; OUTPUT CONTROL OPTIONS =

; Output frequency for coords $(\mathrm{x})$, velocities $(\mathrm{v})$ and forces $(\mathrm{f})=$

nstxout $\quad=50$

nstvout $\quad=0$

nstfout $\quad=0$

; Output frequency for energies to log file and energy file $=$ nstlog = 100

nstenergy $\quad=1$

; Output frequency and precision for xtc file $=$

nstxtcout $\quad=0$

xtc-precision $=1000$ 
; This selects the subset of atoms for the xtc file. You can = ; select multiple groups. By default all atoms will be written. = xtc-grps $=$

; Selection of energy groups $=$

energygrps $=$ Protein NEL SOL CL-

; NEIGHBORSEARCHING PARAMETERS =

; nblist update frequency $=$

nstlist $\quad=5$

; ns algorithm (simple or grid) $=$

ns_type = grid

; Periodic boundary conditions: $x y z$ or no $=$

$\mathrm{pbc} \quad=x y z$

; nblist cut-off $\quad=$

rlist $\quad=1.0$

domain-decomposition $=$ no

; OPTIONS FOR ELECTROSTATICS AND VDW =

; Method for doing electrostatics =

coulombtype = Reaction-field

rcoulomb-switch $=0$

rcoulomb $\quad=1.4$

; Dielectric constant (DC) for cut-off or DC of reaction field $=$ epsilon-r = 54

; Method for doing Van der Waals $=$

vdw-type = Cut-off

; cut-off lengths =

rvdw-switch $\quad=0$

rvdw $\quad=1.2$

; Apply long range dispersion corrections for Energy and Pressure =

DispCorr = EnerPres

; Spacing for the PME/PPPM FFT grid =

fourierspacing $\quad=0.12$

; FFT grid size, when a value is 0 fourierspacing will be used $=$

fourier_nx $\quad=0$

fourier_ny $\quad=0$

fourier_nz $=0$

; EWAL̄D/PME/PPPM parameters =

pme_order $\quad=4$

ewald_rtol $\quad=1 \mathrm{e}-05$

ewald_geometry $\quad=3 d$

epsilon_surface $\quad=0$

optimize_fft =yes

; OPTIONS FOR WEAK COUPLING ALGOHMS =

; Temperature coupling =

Tcoupl = no

; Groups to couple separately =

tc-grps = Protein NEL SOL CL-

; Time constant (ps) and reference temperature $(\mathrm{K})=$ 
tau-t

$$
=0.1 \quad 0.1 \quad 0.1 \quad 0.1
$$

ref-t

$=\begin{array}{llll}300 & 300 & 300 & 300\end{array}$

; Pressure coupling

Pcoupl

$=$ berendsen

Pcoupltype

= Isotropic

; Time constant $(p s)$, compressibility $(1 /$ bar $)$ and reference $P($ bar $)=$

tau-p

$=1$

compressibility $\quad=4.5 \mathrm{e}-5$

ref-p $=1$

; SIMULATED ANNEALING CONTROL = ; annealing = no

; Time at which temperature should be zero $(p s)=$ ;zero-temp_time $\quad=0$

; GENERATE VELOCITIES FOR STARTUP RUN =

gen_vel = no

gen-temp $\quad=300$

gen-seed $\quad=173529$

; OPTIONS FOR BONDS = constraints = none

; Type of constraint algorithm =

constraint-algorithm = Lincs

; Do not constrain the start configuration =

unconstrained-start = no

; Use successive overrelaxation to reduce the number of shake iterations =

Shake-SOR

$$
=\text { no }
$$

; Relative tolerance of shake $=$

shake-tol $\quad=0.0001$

; Highest order in the expansion of the constraint coupling matrix $=$ lincs-order $\quad=4$

; Lincs will write a warning to the stderr if in one step a bond $=$

; rotates over more degrees than $=$

lincs-warnangle $=30$

; Convert harmonic bonds to morse potentials =

morse $\quad=$ no

\section{; ENERGY GROUP EXCLUSIONS =}

; Pairs of energy groups for which all non-bonded interactions are excluded $=$ energygrp_excl=

; NMR refinement stuff $=$

; Distance restraints type: No, Simple or Ensemble =

disre $\quad$ No

; Force weighting of pairs in one distance restraint: Conservative or Equal = disre-weighting = Conservative

; Use sqrt of the time averaged times the instantaneous violation =

disre-mixed = no

disre-fc $\quad=1000$ 
disre-tau $=0$

; Output frequency for pair distances to energy file =

nstdisreout $\quad=100$

; Orientation restraints: No or Yes $=$

orire = no

; Orientation restraints force constant and tau for time averaging =

orire-fc $=0$

orire-tau $\quad=0$

orire-fitgrp =

; Output frequency for trace(SD) to energy file =

nstorireout $\quad=100$

; Free energy control stuff $=$

free-energy = no

init-lambda $\quad=0$

delta-lambda $\quad=0$

sc-alpha $\quad=0$

sc-sigma $\quad=0.3$

; Non-equilibrium MD stuff =

acc-grps =

accelerate $\quad=$

freezegrps =

freezedim =

cos-acceleration $\quad=0$

; Electric fields =

; Format is number of terms (int) and for all terms an amplitude (real) =

; and a phase angle (real) =

$E-X$

E-xt =

E-y =

E-yt =

$\mathrm{E}-\mathrm{Z}=$

E-zt =

; User defined thingies $=$

user1-grps =

user2-grps =

userint1 $\quad=0$

userint2 $\quad=0$

userint3 $\quad=0$

userint4 $\quad=0$

userreal1 $\quad=0$

userreal2 $=0$

userreal3 $=0$

userreal4 $=0$ 


\section{Comando inicial da Dinâmica Molecular com restrição de posição atômica}
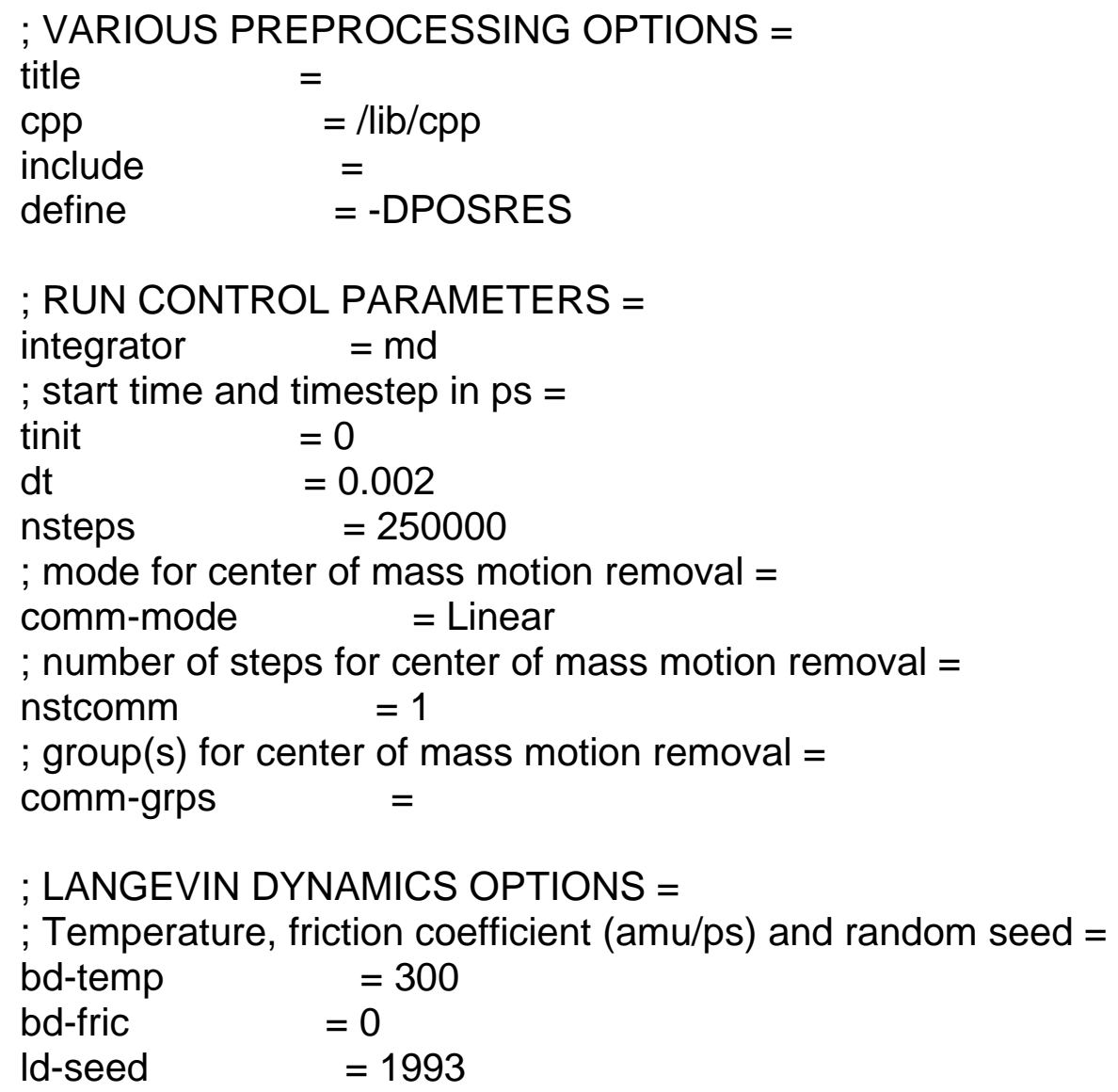

; ENERGY MINIMIZATION OPTIONS =

; Force tolerance and initial step-size $=$

emtol $\quad=42.0$

emstep $\quad=0.01$

; Max number of iterations in relax_shells $=$

niter $\quad=20$

; Step size $\left(1 / \mathrm{ps}^{\wedge} 2\right)$ for minimization of flexible constraints =

fcstep $\quad=0$

; Frequency of steepest descents steps when doing CG =

nstcgsteep $\quad=1000$

; OUTPUT CONTROL OPTIONS =

; Output frequency for coords $(\mathrm{x})$, velocities $(\mathrm{v})$ and forces $(\mathrm{f})=$

nstxout $\quad=5000$

nstvout $\quad=5000$

nstfout $\quad=0$

; Output frequency for energies to log file and energy file $=$

nstlog $=50000$

nstenergy $=50$

; Output frequency and precision for xtc file $=$

nstxtcout $\quad=1000$

xtc-precision $=1000$ 
; This selects the subset of atoms for the xtc file. You can = ; select multiple groups. By default all atoms will be written. = xtc-grps $=$

; Selection of energy groups $=$

energygrps $\quad=$ Protein NEL SOL CL- NA+

; NEIGHBORSEARCHING PARAMETERS =

; nblist update frequency $=$

nstlist $\quad=5$

; ns algorithm (simple or grid) $=$

$$
\text { ns_type = grid }
$$

; Periodic boundary conditions: $x y z$ or no $=$

$\mathrm{pbc} \quad=x y z$

; nblist cut-off $\quad=$

rlist $\quad=1.0$

domain-decomposition $=$ no

; OPTIONS FOR ELECTROSTATICS AND VDW =

; Method for doing electrostatics =

coulombtype = Reaction-field

rcoulomb-switch $\quad=0$

rcoulomb = 1.4

; Dielectric constant (DC) for cut-off or DC of reaction field $=$ epsilon-r = 54

; Method for doing Van der Waals =

vdw-type = Cut-off

; cut-off lengths =

rvdw-switch $\quad=0$

rvdw $\quad=1.2$

; Apply long range dispersion corrections for Energy and Pressure =

DispCorr = EnerPres

; Spacing for the PME/PPPM FFT grid =

$$
\text { fourierspacing } \quad=0.12
$$

; FFT grid size, when a value is 0 fourierspacing will be used $=$

fourier_nx $\quad=0$

fourier_ny $\quad=0$

fourier_nz $=0$

; EWAL̄D/PME/PPPM parameters =

pme_order $\quad=4$

ewald_rtol =1e-05

ewald_geometry $\quad=3 d$

epsilon_surface $\quad=0$

optimize_fft =yes

; OPTIONS FOR WEAK COUPLING ALGORITHMS =

; Temperature coupling $=$

Tcoupl = berendsen

; Groups to couple separately =

tc-grps = Protein NEL SOL CL- NA+

; Time constant $(\mathrm{ps})$ and reference temperature $(\mathrm{K})=$ 
tau-t $=0.1 \quad 0.1 \quad 0.1 \quad 0.1 \quad 0.1$

ref-t $=\begin{array}{lllll}300 & 300 & 300 & 300 & 300\end{array}$

; Pressure coupling =

Pcoupl = berendsen

Pcoupltype = Isotropic

; Time constant (ps), compressibility (1/bar) and reference $P$ (bar) $=$ tau-p = 1

compressibility $\quad=4.5 \mathrm{e}-5$

ref-p $=1$

; SIMULATED ANNEALING CONTROL = ;annealing = no

; Time at which temperature should be zero (ps) = ;zero-temp_time $\quad=0$

; GENERATE VELOCITIES FOR STARTUP RUN = gen_vel =yes

gen-temp $\quad=300$

gen-seed $\quad=173529$

; OPTIONS FOR BONDS = constraints = all-bonds

; Type of constraint algorithm = constraint-algorithm = Lincs

; Do not constrain the start configuration $=$ unconstrained-start = no

; Use successive overrelaxation to reduce the number of shake iterations = Shake-SOR = no

; Relative tolerance of shake $=$ shake-tol $\quad=0.0001$

; Highest order in the expansion of the constraint coupling matrix = lincs-order $=4$

; Lincs will write a warning to the stderr if in one step a bond = ; rotates over more degrees than $=$ lincs-warnangle $=30$

; Convert harmonic bonds to morse potentials = morse $=$ no

; ENERGY GROUP EXCLUSIONS =

; Pairs of energy groups for which all non-bonded interactions are excluded $=$ energygrp_excl =

; NMR refinement stuff $=$

; Distance restraints type: No, Simple or Ensemble = disre $\quad$ No

; Force weighting of pairs in one distance restraint: Conservative or Equal $=$ disre-weighting = Conservative

; Use sqrt of the time averaged times the instantaneous violation $=$ disre-mixed $\quad=$ no

disre-fc $\quad=1000$ 
disre-tau $=0$

; Output frequency for pair distances to energy file =

nstdisreout $\quad=100$

; Orientation restraints: No or Yes $=$

orire = no

; Orientation restraints force constant and tau for time averaging $=$

orire-fc $=0$

orire-tau $\quad=0$

orire-fitgrp =

; Output frequency for trace(SD) to energy file =

nstorireout $\quad=100$

; Free energy control stuff $=$

free-energy = no

init-lambda $\quad=0$

delta-lambda $\quad=0$

sc-alpha $\quad=0$

sc-sigma $\quad=0.3$

; Non-equilibrium MD stuff =

acc-grps =

accelerate $\quad=$

freezegrps =

freezedim =

cos-acceleration $\quad=0$

; Electric fields =

; Format is number of terms (int) and for all terms an amplitude (real) =

; and a phase angle (real) =

$E-X$

E-xt =

E-y =

E-yt =

$\mathrm{E}-\mathrm{Z}=$

E-zt =

; User defined thingies $=$

user1-grps =

user2-grps =

userint1 $\quad=0$

userint2 $\quad=0$

userint3 $\quad=0$

userint4 $\quad=0$

userreal1 $\quad=0$

userreal2 $=0$

userreal3 $=0$

userreal4 $=0$ 


\section{Comando da Dinâmica Molecular para coleta de dados}
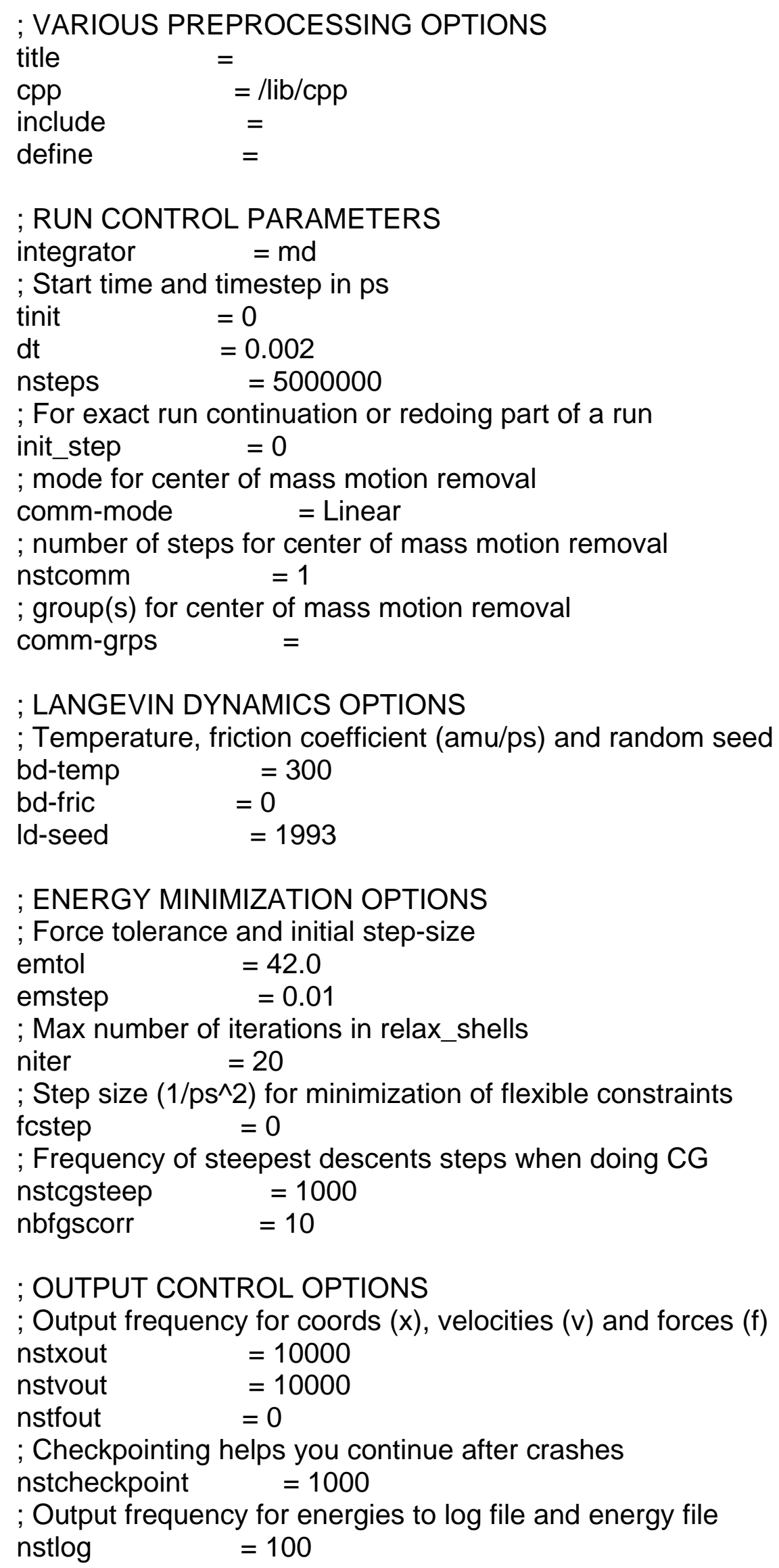


nstenergy $=100$
$\begin{array}{ll}\text {; Output frequency and precision for xtc file } \\ \text { nstxtcout } & =1000 \\ \text { xtc-precision } & =1000\end{array}$

; This selects the subset of atoms for the xtc file. You can

; select multiple groups. By default all atoms will be written.

xtc-grps

; Selection of energy groups

energygrps $\quad=$ Protein NEL SOL CL- NA+

; NEIGHBORSEARCHING PARAMETERS

; nblist update frequency

nstlist $\quad=5$

; ns algorithm (simple or grid)

ns_type = grid

; Periodic boundary conditions: xyz (default), no (vacuum)

; or full (infinite systems only)

$\mathrm{pbc} \quad=\mathrm{xyz}$

; nblist cut-off

rlist $\quad=1.0$

domain-decomposition $=$ no

; OPTIONS FOR ELECTROSTATICS AND VDW

; Method for doing electrostatics

coulombtype = Reaction-Field

rcoulomb-switch $=0$

rcoulomb $\quad=1.4$

; Dielectric constant (DC) for cut-off or DC of reaction field

epsilon-r = 54

; Method for doing Van der Waals

vdw-type = Cut-off

; cut-off lengths

rvdw-switch $\quad=0$

rvdw $\quad=1.2$

; Apply long range dispersion corrections for Energy and Pressure

DispCorr = EnerPres

; Extension of the potential lookup tables beyond the cut-off

table-extension = 1

; Spacing for the PME/PPPM FFT grid

fourierspacing $\quad=0.12$

; FFT grid size, when a value is 0 fourierspacing will be used

fourier_nx $\quad=0$

fourier_ny $\quad=0$

fourier $n z \quad=0$

; EWALED/PME/PPPM parameters

pme_order $=4$

ewald_rtol $=1 \mathrm{e}-05$

ewald_geometry $\quad=3 d$

epsilon_surface $=0$

optimize_fft =yes 
; GENERALIZED BORN ELECTROSTATICS

; Algorithm for calculating Born radii

gb_algorithm = Still

; Frequency of calculating the Born radii inside rlist

nstgbradii $\quad=1$

; Cutoff for Born radii calculation; the contribution from atoms

; between rlist and rgbradii is updated every nstlist steps

rgbradii $=2$

; Salt concentration in M for Generalized Born models

gb_saltconc $\quad=0$

; IMPLICIT SOLVENT (for use with Generalized Born electrostatics)

implicit_solvent = No

; OPTIONS FOR WEAK COUPLING ALGORITHMS

; Temperature coupling

Tcoupl = berendsen

; Groups to couple separately

tc-grps = Protein NEL SOL CL- NA+

; Time constant (ps) and reference temperature (K)

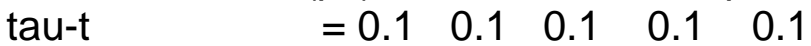

ref-t $\quad=\begin{array}{lllll}300 & 300 & 300 & 300 & 300\end{array}$

; Pressure coupling

Pcoupl = berendsen

Pcoupltype = Isotropic

; Time constant (ps), compressibility (1/bar) and reference P (bar)

tau-p = 1

compressibility $\quad=4.5 \mathrm{e}-5$

ref-p = 1

; Random seed for Andersen thermostat

andersen_seed $\quad=815131$

; SIMULATED ANNEALING

; Type of annealing for each temperature group (no/single/periodic)

annealing =

; Number of time points to use for specifying annealing in each group

annealing_npoints =

; List of times at the annealing points for each group

annealing_time =

; Temp. at each annealing point, for each group.

annealing_temp=

; GENERATE VELOCITIES FOR STARTUP RUN

gen_vel = yes

gen-temp $\quad=300$

gen-seed $\quad=173529$

; OPTIONS FOR BONDS

constraints = all-bonds 


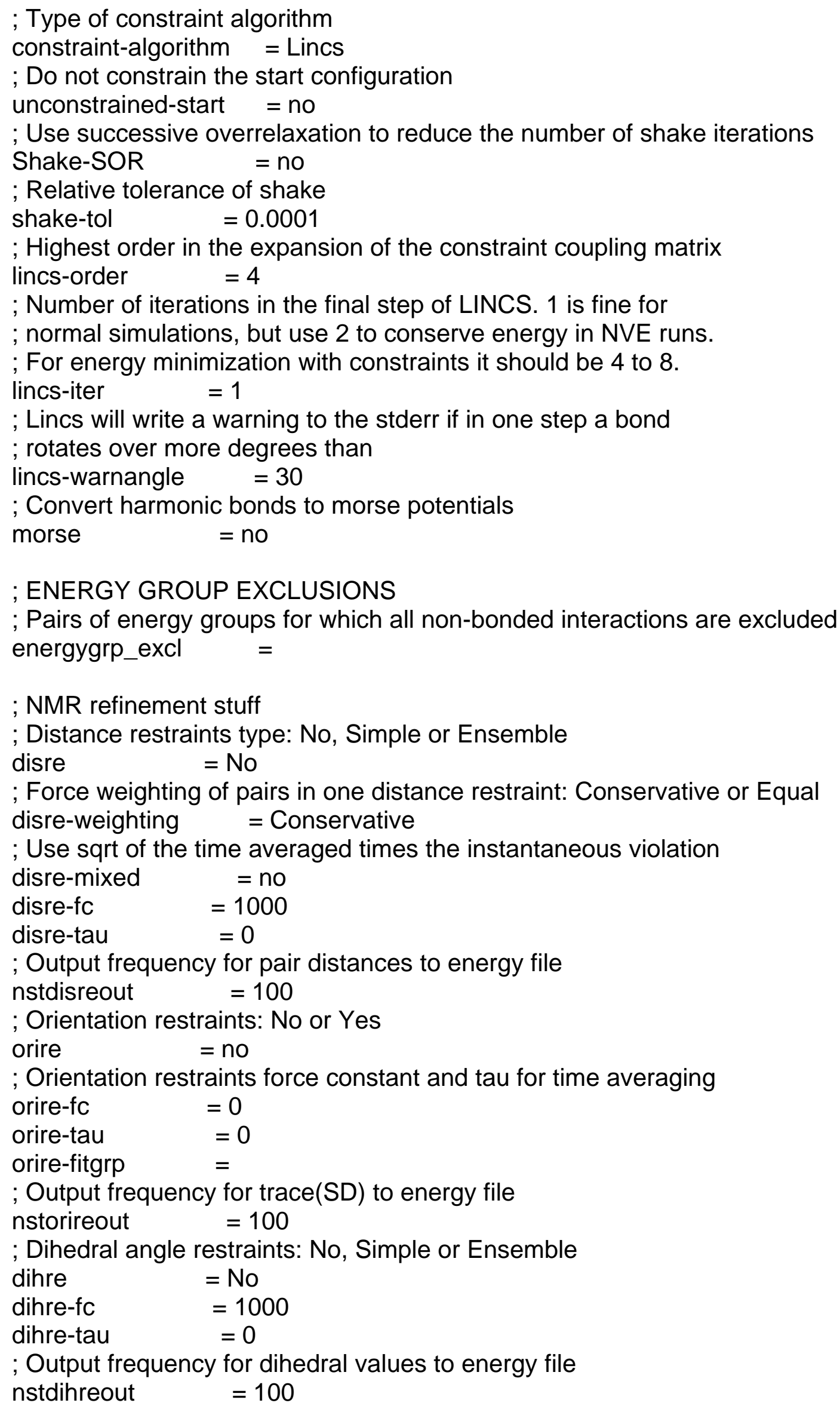




$\begin{array}{lc}\text {; Free energy control stuff } \\ \text { free-energy } & =\text { no } \\ \text { init-lambda } & =0 \\ \text { delta-lambda } & =0 \\ \text { sc-alpha } & =0 \\ \text { sc-sigma } & =0.3\end{array}$

; Non-equilibrium MD stuff acc-grps = accelerate $\quad=$ freezegrps = freezedim = cos-acceleration $\quad=0$

; Electric fields

; Format is number of terms (int) and for all terms an amplitude (real) ; and a phase angle (real)

$E-X$

$E-x t$ $=$ E-y = E-yt = $\mathrm{E}-\mathrm{Z}=$ $\mathrm{E}-\mathrm{zt} \quad=$

; User defined thingies

$\begin{array}{ll}\text { user1-grps } & = \\ \text { user2-grps } & = \\ \text { userint1 } & =0 \\ \text { userint2 } & =0 \\ \text { userint3 } & =0 \\ \text { userint4 } & =0 \\ \text { userreal1 } & =0 \\ \text { userreal2 } & =0 \\ \text { userreal3 } & =0 \\ \text { userreal4 } & =0\end{array}$




\section{ANEXO C - Primers utilizados}

Tabela 1 - Mistura de reação para PCR para fragmentos de pNL4-3.

\begin{tabular}{ccc}
\hline Componente & Volume & [final] \\
\hline 10x Tampão com $\mathrm{Mg}^{2+}$ & $5 \mu \mathrm{l}$ & $1 \times(2.5 \mathrm{mM} \mathrm{Mg}$ \\
$10 \mathrm{mM}$ dNTP Mix & $1 \mu \mathrm{l})$ \\
Oligo A(+) & $1 \mu \mathrm{l}$ & $0.25 \mathrm{mM}$ \\
Oligo B (-) & $1 \mu \mathrm{l}$ & $0.5 \mu \mathrm{M}$ \\
DNA & & $0.5 \mu \mathrm{M}$ \\
High Fidelity Taq DNA & $0.4 \mu \mathrm{l}$ & $100-200 \mathrm{ng}$ \\
$\mathrm{H}_{2} \mathrm{O}$ & completando $50 \mu \mathrm{l}$ & $2 \mathrm{U}$ \\
\hline
\end{tabular}

Fonte: Iamarino (2012).

Tabela 2 - Primers utilizados na construção do vetor pNL4-3 recombinante. Posições em relação ao genoma de referência HXB2.

\begin{tabular}{ccc}
\hline ID & Posição & Sequência (5' $\rightarrow$ 3') \\
\hline Not FW & $2262 \rightarrow 2284$ & ACTCTTTGGCAGCGGCCGCTCGT \\
Not RV 2 2262L23 & $2284 \rightarrow 2262$ & ACGAGCGGCCGCTGCCAAAGAGT \\
Bst FW 2 2544U27 & $2544 \rightarrow 2570$ & AATTTTCGAATTAGTCCTATTGAGACT \\
Bst RV & $2570 \rightarrow 2544$ & AGTCTCAATAGGACTAATTCGAAAATT \\
Spe bst FW & $1500 \rightarrow 1523$ & TGGAACTACTAGTACCCTTCAGGA \\
Bst spe RV & $2570 \rightarrow 2542$ & AGTTTCAATAGGACTAATTCGAAAATTTA \\
\hline
\end{tabular}

Fonte: Iamarino (2012).

Tabela 3 - Primers utilizados para o sequenciamento do vetor pNL4-3 recombinante construído. Posições em relação ao genoma de referência HXB2.

\begin{tabular}{cll}
\hline ID & \multicolumn{1}{c}{ Posição } & \multicolumn{1}{c}{ Sequência $\left(\mathbf{5}^{\prime} \rightarrow \mathbf{3}^{\prime}\right)$} \\
\hline K2 & $623 \rightarrow 649$ & AAATCTCTAGCAGTGGCGCCCGACAG \\
G30NO & $1031 \rightarrow 1051$ & CAGTAGCAACCCTCTATTGTG \\
Spe_bst FW & $1500 \rightarrow 1523$ & TGGAACTACTAGTACCCTTCAGGA \\
HU2 & $1763 \rightarrow 1783$ & ATGCGAACCCAGATTGTAAGA \\
G15CO & $1961 \leftarrow 1981$ & CTTTGCCACAATTGAAACACT \\
HL1 & $2129 \leftarrow 2149$ & GGGGTCTGCTCTGAAGAAAAT \\
K1 & $2147 \rightarrow 2166$ & CAGAGCCAACAGCCCCACCA \\
DP10 & $2198 \rightarrow 2223$ & TAACTCCCTCTCAGAAGCAGGAGCCG \\
F1 & $2519 \rightarrow 2539$ & GTTGACTCAGATTGGTTGCAC \\
Bst_spe RV & $2542 \leftarrow 2570$ & AGTTTCAATAGGACTAATTCGAAAATTTA \\
G2 & $2869 \leftarrow 2890$ & GCATCHCCCACATCYAGTACTG \\
\hline
\end{tabular}

Fonte: Iamarino (2012). 
ANEXO D - Artigos Gerados 


\title{
BF Integrase Genes of HIV-1 Circulating in São Paulo, Brazil, with a Recurrent Recombination Region
}

\author{
Atila lamarino, Fernando Lucas de Melo, Carla Torres Braconi, Paolo Marinho de Andrade Zanotto*
}

Laboratory of Molecular Evolution and Bioinformatics, Department of Microbiology, Biomedical Sciences Institute-ICB II, University of São Paulo, São Paulo, Brazil

\begin{abstract}
Although some studies have shown diversity in HIV integrase (IN) genes, none has focused particularly on the gene evolving in epidemics in the context of recombination. The IN gene in 157 HIV-1 integrase inhibitor-naïve patients from the São Paulo State, Brazil, were sequenced tallying 128 of subtype B ( 23 of which were found in non-B genomes), 17 of subtype $F$ ( 8 of which were found in recombinant genomes), 11 integrases were BF recombinants, and 1 from subtype C. Crucially, we found that $4 \mathrm{BF}$ recombinant viruses shared a recurrent recombination breakpoint region between positions 4900 and 4924 (relative to the HXB2) that includes 2 gRNA loops, where the RT may stutter. Since these recombinants had independent phylogenetic origin, we argue that these results suggest a possible recombination hotspot not observed so far in BF CRF in particular, or in any other HIV-1 CRF in general. Additionally, $40 \%$ of the drug-naïve and $45 \%$ of the drug-treated patients had at least 1 raltegravir (RAL) or elvitegravir (EVG) resistance-associated amino acid change, but no major resistance mutations were found, in line with other studies. Importantly, V151I was the most common minor resistance mutation among B, F, and BF IN genes. Most codon sites of the IN genes had higher rates of synonymous substitutions $(d S)$ indicative of a strong negative selection. Nevertheless, several codon sites mainly in the subtype B were found under positive selection. Consequently, we observed a higher genetic diversity in the B portions of the mosaics, possibly due to the more recent introduction of subtype $F$ on top of an ongoing subtype $B$ epidemics and a fast spread of subtype $F$ alleles among the $\mathrm{B}$ population.
\end{abstract}

\footnotetext{
Citation: lamarino A, de Melo FL, Braconi CT, Zanotto PMdA (2012) BF Integrase Genes of HIV-1 Circulating in São Paulo, Brazil, with a Recurrent Recombination Region. PLoS ONE 7(4): e34324. doi:10.1371/journal.pone.0034324

Editor: Darren P. Martin, Institute of Infectious Disease and Molecular Medicine, South Africa

Received October 18, 2011; Accepted February 25, 2012; Published April 2, 2012

Copyright: (c) 2012 lamarino et al. This is an open-access article distributed under the terms of the Creative Commons Attribution License, which permits unrestricted use, distribution, and reproduction in any medium, provided the original author and source are credited.

Funding: This study was funded by Fundação de Amparo a Pesquisa do Estado de Sao Paulo (FAPESP; projects \#10/19341-4, 00/04205-6 [VGDN program], 08/ 58559-5 [Al], 07/01554-9 [FLM], and 09/16740-8 [CTB]). PMAZ holds a CNPq-PQ scholarship. The funders had no role in the study design, data collection and analysis, decision to publish, or preparation of the manuscript.

Competing Interests: The authors have declared that no competing interests exist.

*E-mail: pzanotto@usp.br
}

\section{Introduction}

In Brazil, BF recombinants have increasing importance in the HIV epidemic [1,2,3], similar to South America [4], despite subtype C [5] prevalence in the country's south region. To date, 9 $\mathrm{BF}$ circulating recombinant forms $(\mathrm{CRFs})$ are worldwide recognized, with 6 of them sampled in Brazil (CRF28_BF, CRF29_BF, CRF38_BF, CRF39_BF, CRF40_BF, and CRF46_BF; www.hiv. lanl.gov). Also, unique recombinant forms (URFs) are commonly found $[6,7,8]$. Currently, there are 4 different antiretroviral therapies (ARV) for HIV treatment based on: (i) fusion inhibitors that inhibit conformational changes in the gp4l that are essential for fusion; (ii) reverse transcriptase (RT) inhibitors, which may be separated into 2 groups, nucleoside analogs (nucleoside reverse transcriptase inhibitors [NRTIs]) or non-nucleoside analogs (nonnucleoside reverse transcriptase inhibitors [NNRTIs]); (iii) protease (PR) inhibitors; and more recently, (iv) integrase inhibitors such as raltegravir (RAL) [9] and elvitegravir (EVG) [10]. The integrase $(I N)$ gene codes for an enzyme responsible for the integration of the full proviral cDNA in the host chromosome. The HIV-1 IN is a 32-kDa protein with 288 amino acids (aa) expressed together with a viral PR and RT as the Pol polyprotein and released by PR cleavage during maturation. This enzyme has 3 distinct functional domains: the N-terminal domain (NTD; aa, 1-49), catalytic core domain (CCD; aa, 50-212), and C-terminal domain (CTD; aa,
213-288) [11]. The NTD has a highly conserved zinc-binding HHCC motif that stabilizes its correct folding. In the CCD, it can be found a highly conserved acidic motif, D64, D116, and E152, in all integrases and retrotransposases [11,12]. The last domain, CTD, binds DNA nonspecifically and plays an important role in the integration process [13]. Although, the $I \mathcal{N}$ gene has become an important target in the ARV therapy, some mutations in the $I \mathcal{N}$ gene also confer resistance to the integrase inhibitors $[14,15]$.

Brazil started offering free access to HAART treatment in 1996 through the public health system. However, only in the beginning of 2008, RAL was approved for clinical use in patients who had HAART failure. Even though there is a large number of patients under ARV therapy, since the beginning of the epidemic, more than 217,000 people died as a consequence of AIDS, and over 630,000 might be infected by HIV [16]. The $I \mathcal{N}$ gene in Brazilian patients was previously studied by Passaes et al., 2009 [17] and Arruda et al., 2010 [18], and major resistance mutations were not found in integrase inhibitor-naïve patients, although minor mutations associated with RAL or EVG resistance were common. Nevertheless, neither of these previous works addressed the key aspect of integrase recombination. Our study aimed to sample the genetic diversity of the $I \mathcal{N}$ gene from the most prevalent subtypes in Brazil, previous to the introduction of RAL in order to evaluate its recombination profiles and drug resistance mutations in a population-genetics context, which is relevant to the epidemic in 
the southern cone in particular, and elsewhere in general, once the Brazilian-borne BF CRFs spread abroad [19].

\section{Methods}

\section{Ethics Statements and Clinical samples}

This study was submitted to and was approved by the Ethics Committee on Human Research of the Centro de Referência e Treinamento-DST/AIDS, Sao Paulo, Brazil, and all the patients signed informed consent terms. Patients were selected from those sampled and subtyped for parts of the gag, pol and env regions during the Viral Genetic Diversity Network (VGDN) program [20]. One hundred fifty-seven HIV-1 samples were obtained from drug-naive and drug-treated individuals; none of which was treated with integrase inhibitors, from different cities of the São Paulo State.

\section{DNA Extraction, PCR, and Sequencing}

DNA was extracted from the infected PBMCs by using QIAamp DNA Blood kit (Qiagen, Germany) according to the manufacturer's instructions and stored at $-80^{\circ} \mathrm{C}$ until use. The nested-PCR and sequencing were carried out according to Van Laethem et al. (2008) [21] (Table S1). PCR products were purified using QIAquick PCR Purification Kit (Qiagen, Germany). Sequencing reactions were performed using BigDye ${ }^{\mathrm{TM}}$ Terminator version 3.0 cycle sequencing (ABI PRISM ${ }^{\circledR}$; PE Applied Biosystems, Foster City, CA), and the products were analyzed on ABI 3100 automated DNA sequencers (PE Applied Biosystems, United States). Sequence data were edited and assembled with the CodonCode Aligner software (Gene Codes Corporation, United States). The sequences were submitted to GenBank under the accession numbers JN234023 to JN234179.

\section{Sequence Analysis}

To expand our original dataset we included all the $I \mathcal{N}$ sequences from Brazil available in GenBank. The sequences were analyzed with the jumping profile hidden Markov model (jpHMM) program $[22,23]$, which uses detailed information on polymorphism of the parental populations rather than using individual parental strains and provides detailed information on the reliability of the predicted recombination breakpoints [24]. The phylogenetic analyses were performed using maximum likelihood (ML) as the optimality criterion. The ML searches were performed using GARLI v0.951 (Os $\times$ GUI) [25] under the general-time reversible (GTR) model with rates estimated from the data. Only sequences without recombination evidence within the integrase region were used for phylogenetic reconstruction. EVG and RAL resistanceassociated mutations and polymorphisms were detected using the Stanford University HIV Drug Resistance Database [26].

\section{Positive Selection Analysis}

Positive selection was determined using the single-likelihood ancestor counting (SLAC) and fixed-effects likelihood (FEL) methods implemented in the HyPhy v2.0 [27]. For the subtype $\mathrm{B}$ analysis, a dataset of 324 integrases (126 new sequences and 198 from GenBank); for the subtype $\mathrm{F}$ analysis, 80 integrases (17 new sequences and 63 references); and for subtype $\mathrm{C}$ analysis, 53 integrase sequences (1 new sequence and 52 references) were compiled. Only results with a $p$-value smaller than 0.05 were considered. We also compared the average rates of synonymous substitutions per site between $I \mathcal{N}$ genes estimated with SLAC from different subtypes, as an approximation of the neutral rate of change. This is justified because it is estimated at codon site positions that may change with less deleterious impact and make special sense for the $I \mathcal{N}$ genes, which are highly conserved and expected to have reduced non-synonymous rates due to purifying selection.

\section{Results}

We examined the almost complete $I \mathcal{N}$ gene (p31; [864 out of 867 bp] genomic positions 4230-5093 in the HXB2 reference) in 157 patients from different cities in the State of São Paulo, Brazil. The jpHMM subtyping analysis revealed that 128 integrases belonged to the subtype $\mathrm{B}, 17$ to the subtype $\mathrm{F}, 11$ to the $\mathrm{BF}$ recombinants (Figure 1), and 1 to the subtype C. To further confirm the viral subtype, we compared the integrase subtyping results with those available for other genomic regions. In addition to the recombinant viruses described above (11/157), another 31 patients were identified as carrying a $\mathrm{BF}$ recombinant virus, despite not having recombinant $I \mathcal{N}$ genes. Eight subtype $\mathrm{F}$ and 23 subtype B integrases were among the subtype BF genomes.

\section{The Origin of Integrase Recombinants}

Since our results indicated that the vast majority of $\mathrm{BF}$ recombinant viruses were not monophyletic (Figure 2), we needed to consider if they had distinct, independent origins as if emerging from distinct co-infection events, despite similarities in their inferred breakpoints. Actually, the high number of URFs, seen in Figure 2, agreed with the reports on a large number of unique BF forms in the Brazilian HIV-1 epidemic [3,6,7]. However, 4 samples shared a recombination breakpoint region between positions 4900 and 4924 (e.g., 0441, 0612, 1426, and 1470) (Figure 1), which could be explained by a shared evolutionary history or maybe by the presence of a recombination hotspot in that particular position in the genome, among other possibilities. To investigate if these recombinants have a common origin, we did a phylogenetic analysis on the first $500 \mathrm{nt}$ (recombination-free segments), including all the subtype $\mathrm{B}$ integrases and 8 recombinant integrases $(0441,0612,0683,0708,1005,1365$, 1426 , and 1470) that shared this 500-bp region with the subtype B.

Nevertheless, only four of the BF integrase sequences had well defined breakpoints, but a short $\mathrm{F}$ portion of around 150 bp-long, making them unsuitable for robust phylogenetic inference on the origin of the $\mathrm{F}$ fragments alone. Figure 3 shows that recombinant sequences dispersed all over the tree as if they had independent origins. We found the posterior probability of a possible shared ancestral node for all the recombinants (i.e., testing for monophyly) to be zero on a set of 5000 plausible trees sampled at stationarity during 2 independent Markov chain Monte Carlo (MCMC) runs, each consisting of 20 million steps with the BEAST v1.6.1. Moreover, we also reconstructed the "recombinant" and "nonrecombinant" states on the same set of plausible trees by using the symmetric CTMC model for discrete character reconstruction with BEAST and found that all recombinant states had posterior probabilities of 0.99 for independent events of transition from "non-recombinant" to "recombinant" nested within the clades of "non-recombinant" integrases with a posterior probability of 1 (Figure 3). We did not find any other HIV CRF genome with a recombination breaking point at that position. The recurrence of independently acquired breaking points suggests some sort of underlying facilitating process at the molecular level. Crucially, the region where recombination breakpoints had the highest posterior probabilities converged in 2 loops, comprising a highly structured viral genomic RNA (gRNA) region [28] (Figure S1) that is prone to RT stalls and strand transfer during HIV cDNA synthesis involved in HIV recombination [28]. 

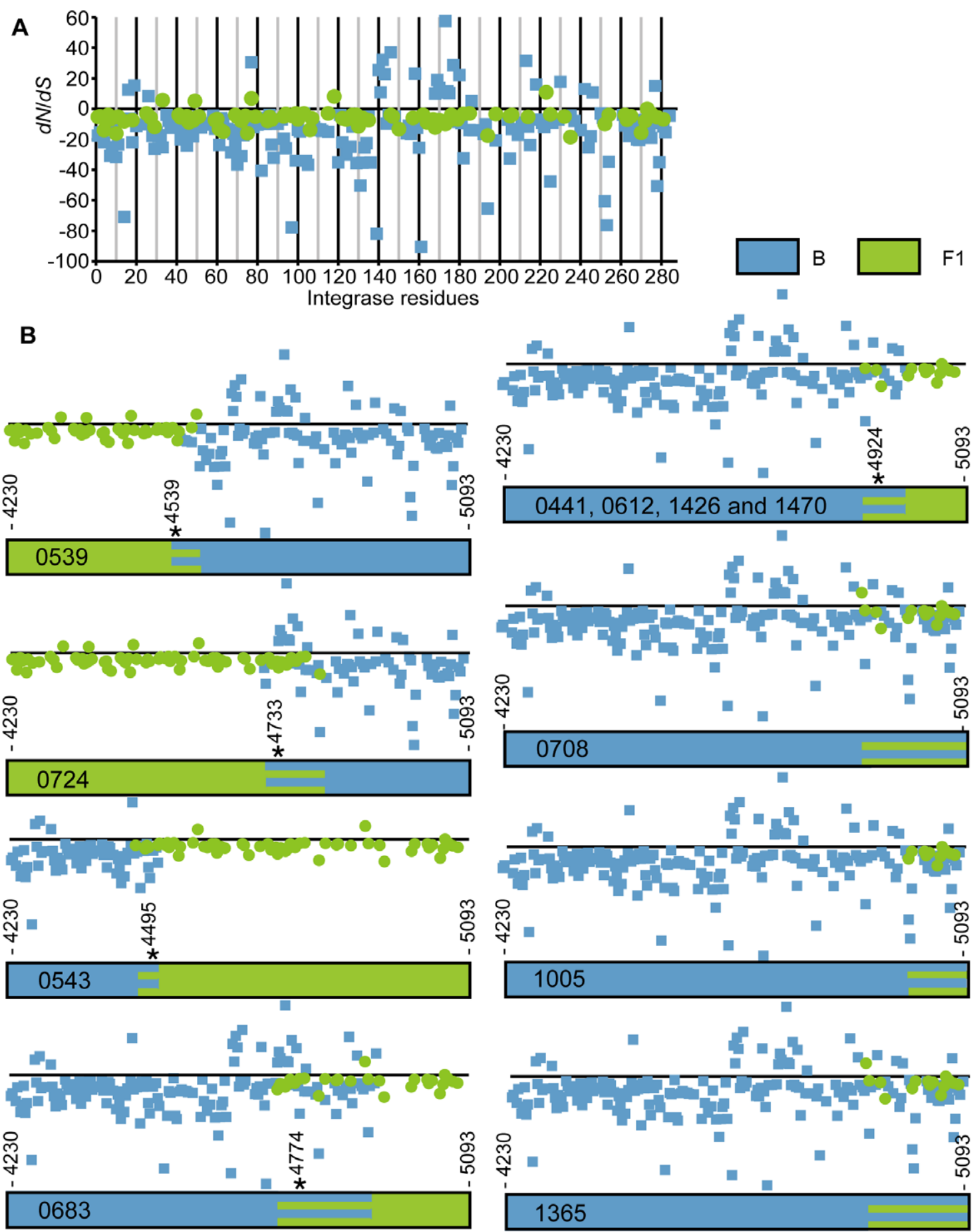

Figure 1. Recombination profiles and selection. Plot of the differences between non-synonymous $(d N)$ and synonymous $(d S)$ rates shown above in the mosaic maps of integrase (864 bp) with nucleotide sites numbered in relation to the HXB2. Rate values per codon site for the subtype B (blue squares) and subtype $F$ (green circles). Blue and green striped portions indicate uncertainty on subtype provenance and usually include the breakpoints (indicated by an asterisk) estimated with jpHMM algorithm available online at the GOBICS server (http://jphmm.gobics.de/jphmm.html). Samples $0441,0612,1365$, and 1470 shared the same breakpoint at nucleotide 4924 that falls inside the uncertainty region from 4899 to 4977 bp but had different recombination profiles on parts of their genomes. Sample 0708 also shared a recombination spot starting at 4899 bp, but no breakpoint could be determined.

doi:10.1371/journal.pone.0034324.g001

\section{Relevant Integrase Polymorphisms}

One hundred and thirty-two of the 157 patients (84.08\%) had already been treated with at least 1 drug regimen (mean, 3 ; up to 13 distinct drug combinations), $85.6 \%$ of which were subjected to
HAART. However, none of them received integrase inhibitors. Forty percent of the drug-naive and $45.5 \%$ of the drug-treated patients had at least 1 RAL or EVG resistance-associated amino acid change, which were values lower than those recently found in 


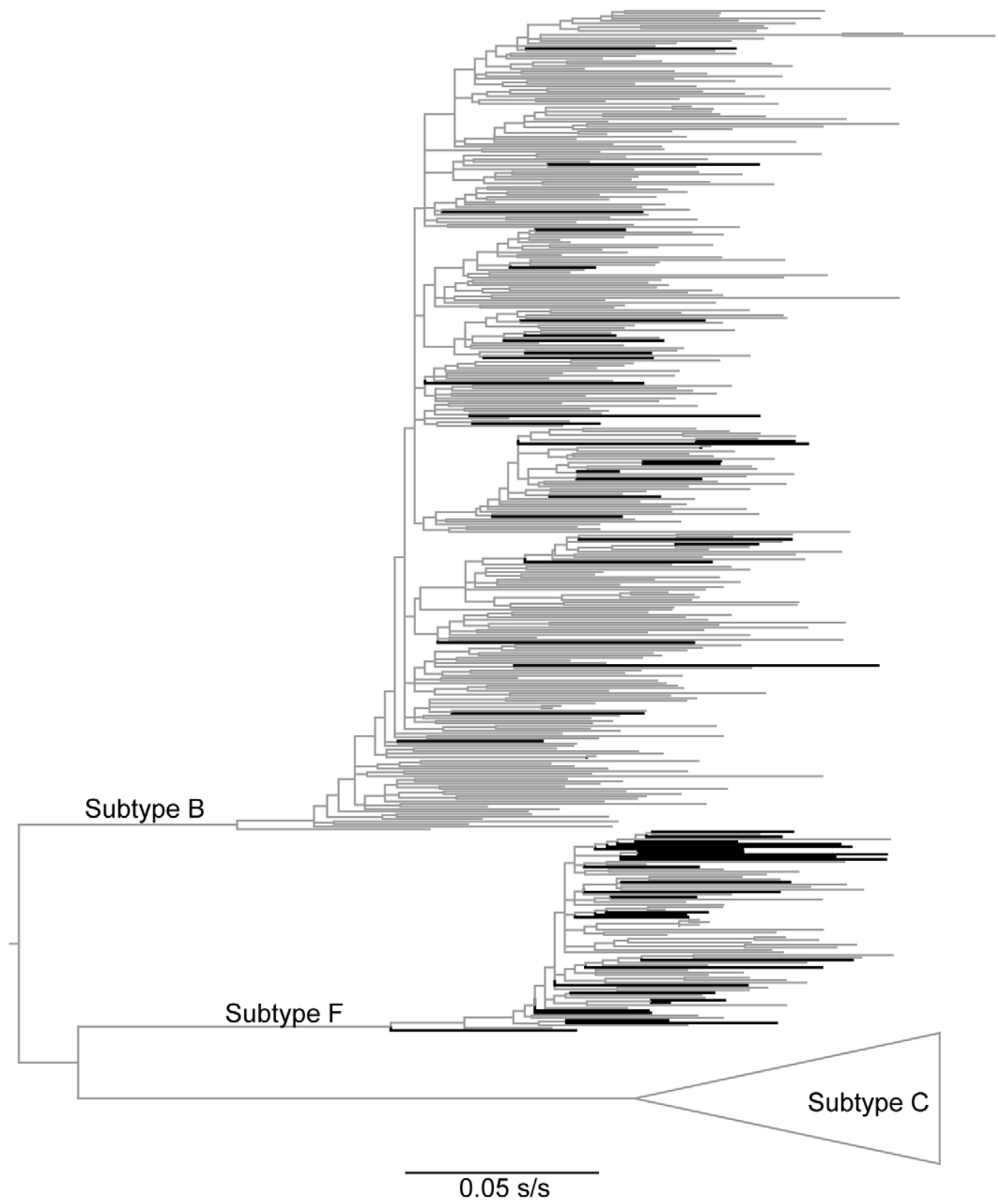

Figure 2. Integrase phylogeny. A maximum likelihood tree for 459 non-recombinant integrase sequences from Brazil (145 generated by us and 314 from other studies) inferred with GARLI v0.95. Thick branches indicate lineages known to be recombinants on other regions of their genomes. The tree was midpoint rooted, which agrees precisely with the known relationship among HIV-1 group $M$ subtypes [34]. Subtype C sequences are collapsed for clarity. This tree shows a large number of potential independent origination events of BF recombinants.

doi:10.1371/journal.pone.0034324.g002

the State of São Paulo [18]. No major resistance mutations (66I, 92Q $140 \mathrm{~A} / \mathrm{S}, 143 \mathrm{R} / \mathrm{C}, 147 \mathrm{G}, 148 \mathrm{H} / \mathrm{R} / \mathrm{K}$, and $155 \mathrm{H})$ were found. Half of the 16 subtype $\mathrm{F}$ integrases had minor resistanceassociated mutations. V151I was the most frequent and found to be present in $65.2 \%(5 / 8)$ of the cases. The polymorphisms E138D, M154I, and S230N were also found in 1 sample each. Our single subtype $\mathrm{C}$ patient was drug-naïve and had no resistance-associated mutation. Likewise, V151I (25\%) was the most common minor resistance mutation among the $\mathrm{BF}$ recombinant integrases, which also had 1 sample sporting M154I. In the subtype B samples, V151I was also the most frequent change in $23.3 \%$ of the patients. Interestingly, unlike the $\mathrm{F}$ and $\mathrm{BF}$ samples, $\mathrm{S} 230 \mathrm{~N}$ was the second most common mutation, present in $8.5 \%$ of the subtype $\mathrm{B}$ sequences. Other $\mathrm{B}$ resistanceassociated mutations were L74M (0.8\%), T97A (1.6\%), E138K $(0.8 \%)$, M154I (3.9\%), M154L (0.8\%), E157K (2.3\%), G163R $(3.1 \%)$, and $\mathrm{I} 203 \mathrm{M}(3.1 \%)$. The complete list of polymorphisms is available in Table $\mathrm{S} 2$.

\section{Selection Regimen}

Figure 1 shows the difference between non-synonymous $(d N)$ and synonymous $(d S)$ rates at each codon of the $I \mathcal{N}$ genes. Positive values indicate an excess of $d \mathcal{N}$ that is indicative of a directional or positive selection, while negative values indicate codons under higher $d S$ rates, suggestive of purifying or negative selection. The extent of the differences indicates the strength of selection. Based 


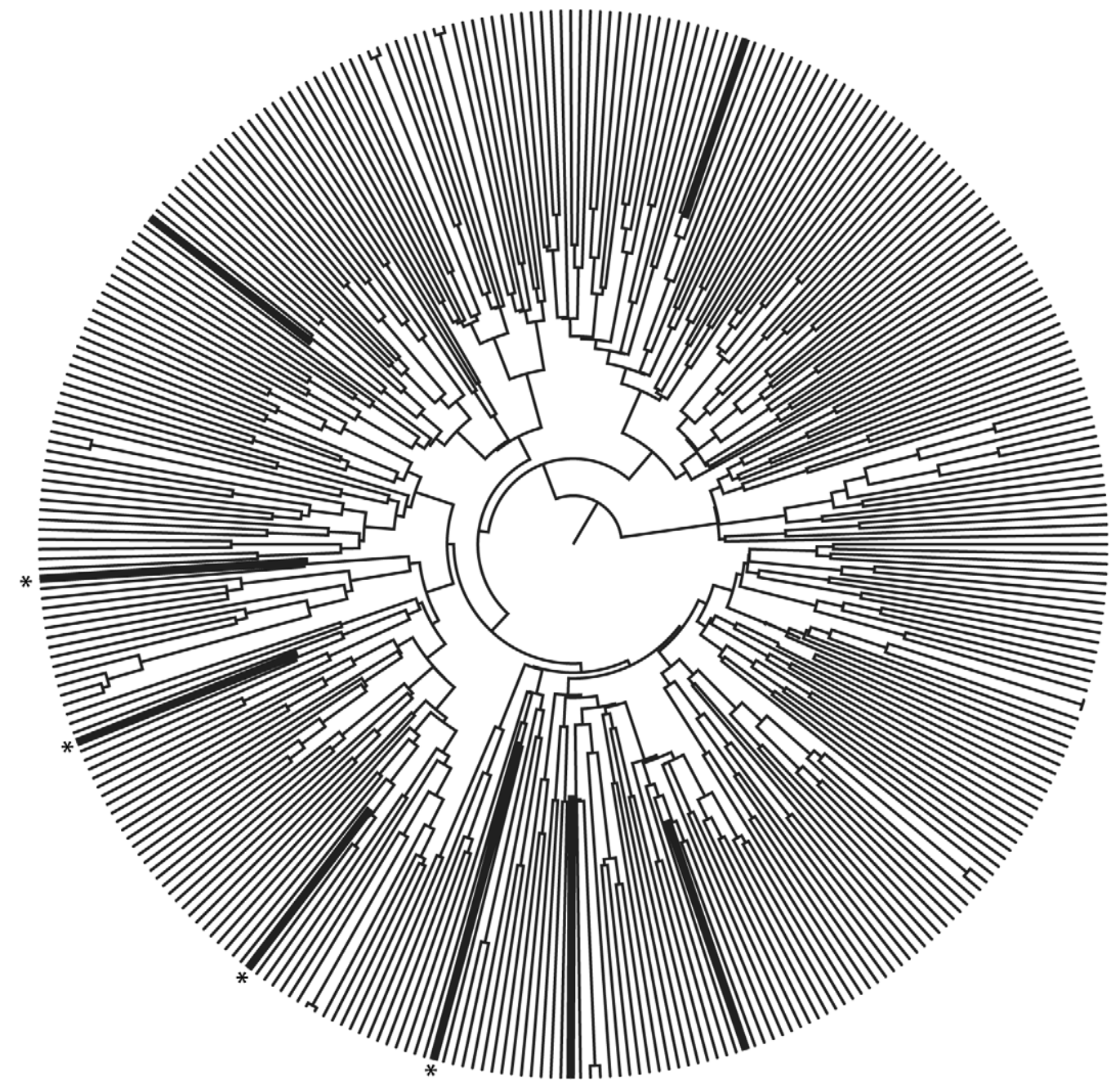

Figure 3. Phylogenetic tree using recombination-free segment. The cladogram summarizes the maximum clade credibility (MCC) tree including all subtype B integrases and the recombinant integrase sequences sharing the 500 bp subtype B segment. It shows reconstructions in "recombinant" and "non-recombinant" state transitions on a set of 5000 plausible trees by using the symmetric CTMC model for discrete character reconstruction with BEAST. Recombinant sequences are shown as thick branches, while asterisks at the tips of the MCC tree show sequences that share a breakpoint at position 4924. Branch lengths only help the visualization of transition events and are not proportional to either quantity of events or substitution per sites.

doi:10.1371/journal.pone.0034324.g003

only on $d S$ values, it can be observed higher genetic diversity in the $\mathrm{B}$ portions of the mosaics, which is in agreement with the notion of a more recent introduction of the $\mathrm{F}$ on top of a $\mathrm{B}$ epidemic, possibly in concert with a fast spread of $\mathrm{F}$ alleles among the $\mathrm{B}$ population. The fact that most of the codon sites of the integrase had higher $d S$ agrees with its functional relevance for viral replication revealed by the strong negative selection on deleterious changes. Nevertheless, several codon sites mainly in the subtype B were found under positive selection using the SLAC method, despite the fact that the integrase is relatively conserved compared to other HIV-1 genes. Some of the positively selected sites, such as residue 72 in the subtype $\mathrm{B}$ and $\mathrm{F}$ integrases and residues 151 and 201 in the subtype B, were further confirmed using FEL. Moreover, the subtype $\mathrm{F}$ integrases had 3 additional positively selected sites at the CCD. Subtype B, on the other hand, presented many positively selected sites, including residues with important biological functions, such as the active site loop (aa, 140) [11]. Interaction with human lens epithelium-derived growth factor (LEDGF/p75; aa: 161, 166, 168, and 171) [29,30], DNA binding (aa, 163) [30], and the nuclear import signal (aa, 165 and 166) [31]. At the CTD, positive selection was found only in the subtype B integrase, including at the DNA binding sites (aa: 230, 234, and 284) [29]. At the NTD, the subtype B and subtype F had 2 positively selected sites (at residues: 17 and 24 and at residues 31 and 45 , respectively). Furthermore, the most common BF integrase recombination profile (breakpoint at residue 232) preserved the positively selected NTD and CCD domains, and the subtype F conserved the DNA binding site at CTD. We also found that the B integrases $\left(d S_{B}=14.42 \pm 1.88\right)$ had a 4.74 times higher rate of change estimated at silent sites $(d S)$ compared to $\mathrm{F}$ integrases $\left(d S_{F}=3.04 \pm 0.44\right)\left(d S_{B}>d S_{F}\right.$, with a probability of $5.9 \mathrm{E}$ 28 of being the same value given a Student's paired $t$-test, with a 2tailed distribution). This huge difference entails a larger population size and possibly an earlier entry of the subtype B in our epidemics. The complete list of positively selected sites is available in Table S3. 


\section{Discussion}

We found that the $I \mathcal{N}$ gene of the HIV-l circulating in the epidemics in the São Paulo State displayed a diverse plethora of $\mathrm{BF}$ recombinants. Our findings are relevant since not much is known about the diversity of circulating viruses and their background resistance-associated polymorphisms in general. The absence of major integrase resistance mutations in our integrase inhibitor-naïve patients, $79 \%$ of which were under ARV drugs such as RT and PR inhibitors, is in line with other studies [17,18] and justifies the use of this therapeutic strategy. None of the 11 recombinant integrases we found shared the same breakpoints with the already described BF CRFs from Brazil, although CRF47_BF from Spain has a breakpoint close to those found in 0441, 0612, 1426, and 1470. These results show the importance of sequencing different genomic regions for improving HIV subtyping and give information on the potential of the underestimation of the real diversity of BF recombinants in our epidemics. Moreover, we tested the hypothesis that the recombinant genes originated from a single common ancestral recombination event (testing for monophyly) by calculating the posterior probability (that was zero) of monophyly on a set of 5000 plausible trees sampled at stationarity during 2 independent MCMC runs. We also checked these results by reconstructing the "recombinant" and "nonrecombinant" states on the same set of plausible trees. This exercise also reinforced (with posterior probability of 1) the hypothesis of an independent origin of "recombinant" from "nonrecombinant" states within the clades of "non-recombinant" integrases. Critically, both independent approaches provided strong statistical support for the notion that the recombinant sequences we found originated from distinct recombination events. That being the case and given the fact that the recurrent recombination region (Figure S2) fell within a secondary gRNA structural feature known to propitiate recombination, we argue that it may indicate a potential recombination hotspot, which was not previously reported for HIV-1 in general and BF recombinants in particular. Nevertheless, $I \mathcal{N}$ is a very conserved region and therefore prone to recombination [32,33]. Moreover, we cannot be sure of the extent to which our estimates could have been influenced by the recombination itself. This is because recombinants with common origin could differentiate later by distinct subsequent recombination events with divergent parental strains

\section{References}

1. Bello G, Guimaraes ML, Morgado MG (2006) Evolutionary history of HIV-1 subtype B and F infections in Brazil. AIDS 20: 763-768.

2. de Souza AC, de Oliveira CM, Rodrigues CL, Silva SA, Levi JE (2008) Short communication: Molecular characterization of HIV type $1 \mathrm{BF}$ pol recombinants from Sao Paulo, Brazil. AIDS Res Hum Retroviruses 24: 1521-1525.

3. Sanabani S, Kleine Neto W, Kalmar EM, Diaz RS, Janini LM, et al. (2006) Analysis of the near full length genomes of HIV-1 subtypes B, F and BF recombinant from a cohort of 14 patients in Sao Paulo, Brazil. Infect Genet Evol 6: $368-377$.

4. Zhang M, Foley B, Schultz AK, Macke JP, Bulla I, et al. (2010) The role of recombination in the emergence of a complex and dynamic HIV epidemic. Retrovirology 7: 25.

5. Gonsalez CR, Alcalde R, Nishiya A, Barreto CC, Silva FE, et al. (2007) Drug resistance among chronic HIV-1-infected patients naive for use of anti-retroviral therapy in Sao Paulo city. Virus Res 129: 87-90.

6. De Sa Filho DJ, Sucupira MC, Caseiro MM, Sabino EC, Diaz RS, et al. (2006) Identification of two HIV type 1 circulating recombinant forms in Brazil. AIDS Res Hum Retroviruses 22: 1-13.

7. Sa Filho DJ, Sanabani S, Diaz RS, Munerato P, Brunstein A, et al. (2005) Analysis of full-length human immunodeficiency virus type 1 genome reveals a variable spectrum of subtypes B and f recombinants in Sao Paulo, Brazil. AIDS Res Hum Retroviruses 21: 145-151.

8. Sanabani S, Neto WK, de Sa Filho DJ, Diaz RS, Munerato P, et al. (2006) Fulllength genome analysis of human immunodeficiency virus type 1 subtype $\mathrm{C}$ in Brazil. AIDS Res Hum Retroviruses 22: 171-176. (i.e., second-generation recombinants). We also observed a 4.7times higher accumulation of diversity in the B subtypes compared to $\mathrm{F}$ subtypes in the $I \mathcal{N}$ genes. Since there was a reduction in the number of positively selected sites in the $\mathrm{F}$ regions and given that the most positively selected sites were detected at the B portion of recombinant forms, we argue that this higher genetic diversity could be explained by a more recent introduction of $\mathrm{F}$ on top of a $\mathrm{B}$ epidemics and a fast spread of $\mathrm{F}$ alleles among the larger $\mathrm{B}$ population. It remains to be investigated if the advantage conferred by the $\mathrm{F}$ portions may have to do with the intrinsic $\mathrm{F}$ integrase functionality or adaptive changes acquired following coinfection.

\section{Supporting Information}

Figure S1 Breakpoint region in secondary RNA structure. Secondary structure of the HIV genomic RNA (gRNA) numbered according to HXB2. The red region marks the recombination hotspot from bases 4900 to 4924. Adapted from Watts J. M. et al. (2009).

(TIF)

Figure S2 Recombination posterior probabilities. Posterior probabilities according to jpHMM of the subtypes for patients 0441 (A), 0612 (B), 1426 (C), and 1470 (D).

(TIF)

Table S1 Primers used for nested amplification of the HIV-1 IN region from according to Van Laethem K.V. et al. (2008). (DOG)

Table S2 Complete list of polymorphisms found at integrase sequences. Minor resistance mutations are shown in red. (DOC)

Table S3 Positively selected sites in the HIV-1 integrase gene coding region.

(DOG)

\section{Author Contributions}

Conceived and designed the experiments: AI FLM CTB PMAZ. Performed the experiments: AI FLM CTB. Analyzed the data: AI FLM CTB PMAZ. Contributed reagents/materials/analysis tools: AI FLM CTB PMAZ. Wrote the paper: AI FLM CTB PMAZ.

Grinsztejn B, Nguyen BY, Katlama C, Gatell JM, Lazzarin A, et al. (2007) Safety and efficacy of the HIV-1 integrase inhibitor raltegravir (MK-0518) in treatment-experienced patients with multidrug-resistant virus: a phase II randomised controlled trial. Lancet 369: 1261-1269.

10. DeJesus E, Berger D, Markowitz M, Cohen C, Hawkins T, et al. (2006) Antiviral activity, pharmacokinetics, and dose response of the HIV-1 integrase inhibitor GS-9137 (JTK-303) in treatment-naive and treatment-experienced patients. J Acquir Immune Defic Syndr 43: 1-5.

11. Engelman A, Craigie R (1992) Identification of conserved amino acid residues critical for human immunodeficiency virus type 1 integrase function in vitro. J Virol 66: 6361-6369.

12. Kulkosky J, Jones KS, Katz RA, Mack JP, Skalka AM (1992) Residues critical for retroviral integrative recombination in a region that is highly conserved among retroviral/retrotransposon integrases and bacterial insertion sequence transposases. Mol Cell Biol 12: 2331-2338.

13. Pommier Y, Johnson AA, Marchand C (2005) Integrase inhibitors to treat HIV/ AIDS. Nat Rev Drug Discov 4: 236-248.

14. Lataillade M, Chiarella J, Kozal MJ (2007) Natural polymorphism of the HIV-1 integrase gene and mutations associated with integrase inhibitor resistance. Antivir Ther 12: 563-570.

15. Malet I, Delelis O, Valantin MA, Montes B, Soulie C, et al. (2008) Mutations associated with failure of raltegravir treatment affect integrase sensitivity to the inhibitor in vitro. Antimicrob Agents Chemother 52: 1351-1358.

16. Ministério da Saúde do Brasil, Secretaria de Vigilância em Saúde, Programa Nacional de DST e AIDS (2010) Boletim Epidemiológico. Ano VII n0 0101 / 12/2010 ed: Brasília. 32 p. 
17. Passaes CP, Guimaraes ML, Bello G, Morgado MG (2009) Near full-length genome characterization of HIV type 1 unique $\mathrm{BC}$ recombinant forms from Southern Brazil. AIDS Res Hum Retroviruses 25: 1339-1344.

18. Arruda LB, Fonseca LA, Duarte AJ, Casseb J (2010) Genetic diversity on the integrase region of the pol gene among HIV type 1-infected patients naive for integrase inhibitors in Sao Paulo City, Brazil. AIDS Res Hum Retroviruses 26: $105-107$.

19. Bruselles A, Rozera G, Bartolini B, Prosperi M, Del Nonno F, et al. (2009) Use of massive parallel pyrosequencing for near full-length characterization of a unique HIV Type 1 BF recombinant associated with a fatal primary infection. AIDS Res Hum Retroviruses 25: 937-942.

20. Pardini MI, Jamal LF, Durigon EL, Massad E, Perez JF, et al. (2008) Boosting virology in Brazil. PLoS Biol 6: e57.

21. Van Laethem K, Schrooten Y, Covens K, Dekeersmaeker N, De Munter P, et al. (2008) A genotypic assay for the amplification and sequencing of integrase from diverse HIV-1 group M subtypes. J Virol Methods 153: 176-181.

22. Schultz AK, Zhang M, Leitner T, Kuiken C, Korber B, et al. (2006) A jumping profile Hidden Markov Model and applications to recombination sites in HIV and HCV genomes. BMC Bioinformatics 7: 265.

23. Zhang M, Schultz AK, Calef C, Kuiken C, Leitner T, et al. (2006) jpHMM at GOBICS: a web server to detect genomic recombinations in HIV-1. Nucleic Acids Res 34: W463-W465.

24. Schultz AK, Zhang M, Bulla I, Leitner T, Korber B, et al. (2009) jpHMM: Improving the reliability of recombination prediction in HIV-1. Nucleic Acids Res 37: W647-W651.
25. Zwickl DJ (2006) Genetic algorithm approaches for the phylogenetic analysis of large biological sequence datasets under the maximum likelihood criterion [Doctoral Thesis]. Austin: The University of Texas.

26. Shafer RW (2006) Rationale and uses of a public HIV drug-resistance database. J Infect Dis 194 Suppl 1: S51-58.

27. Pond SLK, Posada D, Gravenor MB, Woelk CH, Frost SDW (2006) Automated phylogenetic detection of recombination using a genetic algorithm. Mol Bio Evol 23: 1891-1901.

28. Watts JM, Dang KK, Gorelick RJ, Leonard CW, Bess JW, Jr., et al. (2009) Architecture and secondary structure of an entire HIV-1 RNA genome. Nature 460: 711-716.

29. Ceccherini-Silberstein F, Malet I, D'Arrigo R, Antinori A, Marcelin AG, et al. (2009) Characterization and structural analysis of HIV-1 integrase conservation. AIDS Rev 11: 17-29.

30. Maertens GN, Hare S, Cherepanov P (2010) The mechanism of retroviral integration from X-ray structures of its key intermediates. Nature 468: 326-329.

31. Bouyac-Bertoia M, Dvorin JD, Fouchier RA, Jenkins Y, Meyer BE, et al. (2001) HIV-1 infection requires a functional integrase NLS. Mol Cell 7: 1025-1035.

32. Magiorkinis G, Paraskevis D, Vandamme AM, Magiorkinis E, Sypsa V, et al. (2003) In vivo characteristics of human immunodeficiency virus type 1 intersubtype recombination: determination of hot spots and correlation with sequence similarity. J Gen Virol 84: 2715-2722.

33. Thomson MM, Najera R (2005) Molecular epidemiology of HIV-1 variants in the global AIDS pandemic: an update. AIDS Rev 7: 210-224

34. McCutchan FE (1999) Global Diversity in HIV. In: Crandall KA, ed. The evolution of HIV. Baltimore: The Johns Hopkins University Press. pp 41-104. 


\section{PLOS ONE}

\section{The phylodynamics of HIV-1 BF recombinants replacing subtype B following HAART introduction in Argentina \\ --Manuscript Draft--}

\section{Manuscript Number:}

Article Type:

Full Title:

\section{Short Title:}

Corresponding Author:

Keywords:

\section{Abstract:}

\section{Order of Authors:}

Suggested Reviewers:

Opposed Reviewers:

\section{Research Article}

The phylodynamics of HIV-1 BF recombinants replacing subtype B following HAART introduction in Argentina

HIV-1 dynamics after HAART in Argentina

Paolo Marinho de Andrade Zanotto

University of São Paulo

São Paulo, São Paulo BRAZIL

HIV-1 BF recombinants; HAART; drug resistance; phylodynamics of HIV

Argentina has had two different HIV-1 epidemics, one caused by subtype B among men who have sex with men (MSM) and, more recently, a larger one caused by BF recombinants among injecting drug users and the general population (heterosexuals). To understand the differences between the growth patterns of $B$ and BF, we inferred the phylodynamics of pol sequences sampled in 1999 and 2000. We observed a fast growth of recombinant BF viruses concomitant with an abrupt decline in growth of subtype B in the late 1990's. These events coincided with the reduction of new cases amongst MSM and the introduction of free universal access to highly active antiretroviral therapy (HAART). Crucially, our findings suggest that the reduction of subtype B growth and its replacement by faster-growing BF recombinants is not necessarily the product of lineage competition or displacement, but perhaps a combination of differential niche exploitation and response to therapy.

Atila lamarino

Gabriel Deluchi

Jorge A. Benetucci

Caio C.M. Freire

Paolo Marinho de Andrade Zanotto

Petroni Alejandro

Luiz Janini

Universidade Federal de São Paulo Mlcrobiology, Imunnobiology and Parasitology janini@unifesp.br

Claus Wilke

University of Texas Integrative Biology cwilke@mail.utexas.edu

Amilcar Tanuri

Universidade Federal do Rio de Janeiro atanuri@biologia.ufrj.br

Thomas Leitner

Los Alamos National Laboratory Theoretical Biology \& Biophysics tkl@lanl.go

Paula Aulicino

Laboratorio de Biología Celular y Retrovirus

paulicino@garrahan.gov.ar

Has done similar research on Argentina and may have conflict of interest 
Title: The phylodynamics of HIV-1 BF recombinants replacing subtype B following HAART introduction in Argentina

\author{
Authors: Atila Iamarino ${ }^{1}$, Gabriel Deluchi ${ }^{2}$, Jorge A. Benetucci ${ }^{2}$, Caio C.M. Freire ${ }^{1}$, Paolo M. \\ de A. Zanotto ${ }^{1 *}$ and Alejandro Petroni ${ }^{2}$
}

1. Laboratory of Molecular Evolution and Bioinformatics, Department of Microbiology, Biomedical Sciences Institute - ICBII, University of São Paulo, São Paulo, Brazil.

2. Laboratorio de Retrovirus y Virus Asociados, Fundación de Ayuda al Inmunodeficiente (FUNDAI), Buenos Aires, Argentina.

\author{
*Corresponding author: \\ Paolo Marinho de Andrade Zanotto \\ University of Sao Paulo - USP \\ Biomedical Sciences Institute - ICB II \\ Department of Microbiology \\ Av. Prof. Lineu Prestes, 1734 \\ Sao Paulo - SP - Brazil - 05508-000 \\ Phone: 551130918453 \\ Fax: 551130917354 \\ e-mail:pzanotto@usp.br
}




\begin{abstract}
Argentina has had two different HIV-1 epidemics, one caused by subtype B among men who have sex with men (MSM) and, more recently, a larger one caused by BF recombinants among injecting drug users and the general population (heterosexuals). To understand the differences between the growth patterns of $\mathrm{B}$ and $\mathrm{BF}$, we inferred the phylodynamics of pol sequences sampled in 1999 and 2000. We observed a fast growth of recombinant BF viruses concomitant with an abrupt decline in growth of subtype B in the late 1990's. These events coincided with the reduction of new cases amongst MSM and the introduction of free universal access to highly active antiretroviral therapy (HAART). Crucially, our findings suggest that the reduction of subtype B growth and its replacement by faster-growing BF recombinants is not necessarily the product of lineage competition or displacement, but perhaps a combination of differential niche exploitation and response to therapy.
\end{abstract}

\title{
Analysis
}

Argentina is an example of two different HIV-1 epidemics, a first one caused by subtype B infections among men who have sex with men (MSM) and a more recent one caused by BF recombinants in injecting drug users (IDUs) and in the general heterosexual population [1]. Both IDUs and heterosexuals comprise the major risk group since 1996 [2]. A similar development happened in Thailand, where the IDU-associated subtype B was later surpassed by the recombinant CRF01_AE, circulating preferentially among heterosexuals [3]. The fast spread of BF recombinants in Argentina has already been shown [4], but it remains unclear why subtype B prevalence declined in the presence of recombinants [1], while more than half MSM were still engaged in unprotected sex by 2000 and 2001 [5]. To better understand this issue, we studied HIV-1 pol sequences from patients sampled soon after the change in prevalence among risk groups in Argentina. The ethics committee of the Fundación de Ayuda al Inmunodeficiente (FUNDAI) reviewed and approved this study proposal. Written 
consent to this study was obtained from all adult participants and from parents or guardians in the case of enrolled children. All participants have their identities undisclosed. We used 133, 1026bp-long HIV-1 pol sequences from 132 patients from Argentina, including men, women and children, who attended the FUNDAI Laboratory between June 1999 and February 2000, due to antiretroviral therapy failure. The Accession Numbers of nucleic acid sequences used in this study are in Supplementary Table. Sequences were analyzed with the jumping profile hidden Markov model (jpHMM) program [6,7], to unveil potential mosaic viruses and determine recombination breakpoints. From all samples, 83 had a subtype B pol region. From $50 \mathrm{BF}$ recombinants, 23 had $\mathrm{BF}$ proteases and $\mathrm{B}$ reverse transcriptases with a similar recombination profile to CRF12 [8] (CRF12-like), and the remaining 27 fell into 4 haplotypes (Supplementary Figure 1 and Supplementary Table). Phylodynamics based on viral genealogies were inferred with the Bayesian Markov chain Monte Carlo (MCMC) method implemented in BEAST v1.6.2 [9], under the Gaussian Markov random fields (GMRF) Bayesian skyride [10]. Under both, strict and relaxed (uncorrelated lognormal) molecular clocks [11] we estimated an average rate of $0.00153 \mathrm{~s} / \mathrm{s} / \mathrm{y}$ (substitutions per site per year), which was a plausible value for the pol gene [12]. Three independent MCMC runs, each consisting of 50 million generations, were necessary to obtain convergence of parameter estimates (plotted in Supplementary Figure 2). We also compared alternative demographic models (constant, exponential and logistic growth) to find which one best fit the data, with Bayes factor $(B f)$ above 20 as an indication of significant difference between models. Convergence of parameters was assessed by the Effective Sample Size (ESS) values > 200 calculated with the TRACER v1.5 program [13].

The time to the most recent common ancestor (TMRCA) for subtype B sequences was $1957 \pm 5$ (95\% high probability density, HPD), agreeing with time of isolation of HIV-1 in Haiti in 1959 [14]. The TMRCA for CRF12-like sequences was $1967 \pm 6$, which was similar 
to independent estimates [15]. These results are in line with the fact that subtype B was detected in MSM in Argentina during the first half of 1980's [Boletín sobre el SIDA en la República Argentina, 16], before the spread of subtype F, reproducing the epidemic seen in Europe and North America. Figure 1A shows differences in growth between subtype B and BF (CRF12-like), which suggest both, a fast growth of recombinant BF (CRF12-like) viruses from mid 1980's to 2000 and, a sharp decline in growth of subtype B from mid 1990's. Accordingly, B and BF growth was not constant ( $B f$ of 80.62 for B and 70.62 for BF) and the best demographic model for BF viruses was the exponential, with a $B f$ of 2.2 in favor of the logistic model. Subtype B had a complex fluctuating dynamics precluding fitting of simple demographic models we used. A close inspection of the absolute fitness $\left(w_{a b s}\right)$ [17], approximated by the ratio of effective population size estimates $(N e . g$, that would approximate the number of inferred infection events) of subsequent time points (i.e., $w_{a b s}=$ $N e . g_{\mathrm{t}} / N e . g_{\mathrm{t}-1}$, under the assumption of selection acting on all $\left.N e . g_{\mathrm{t}}\right)$, for each subtype from 1990 to 2000 (Figure 1B), depicts the intense continuous growth of BF with a sustained $w_{a b s}$ $>1$ at that period. On the other hand, subtype B growth and its fitness decreased continuously since 1985, and have been significantly affected in the late 1990's, when it showed an abrupt decline in growth, also indicated by $w_{a b s}<1$ (Figure 1B).

\section{Discussion}

Our skyride plots (Figure 1A) indicated a fast increase in the growth rate of CRF12like viruses since early 1980 's. On the other hand, despite their earlier growth, subtype B viruses had a steady decline in the mid 1990's (Figure 1A). This was also when MSM was replaced by heterosexual sex as a major risk factor, taking place alongside a decline in IDU cases [2]. Notably, this trend was also captured by our dynamics compared to the number of cases from risk groups (Figure 1B). Critically, the dynamics profiles and absolute fitness values in time (Figure 1B) suggested that BF recombinants did not necessarily displace 
subtype B by strain competition. Competition would be expected to have caused a sharp acceleration in the number of BF infections after B decrease and an increase of absolute fitness of BF at the expense of B, which was not the case. Conceivably subtype B was deterred by some other factor that had little or no impact on BF recombinants. This assumption is also coherent with the fact that $\mathrm{BF}$ and $\mathrm{B}$ were kept segregated by circulating mainly among distinct risk groups [1], which would impose some form of niche compartmentalization instead of direct competition amongst HIV-1 lineages.

Another potential key factor was that the health authorities in Argentina implemented free universal access to therapy in 1990, followed by the introduction of highly active antiretroviral therapy (HAART) in the second semester of 1996, followed by a decline in HIV-1 cases [Boletín sobre el SIDA en la República Argentina, 16]. Our inferred dynamics apparently detected the effects of these public health measures, since we can observe an impact in subtype B growth, but not in the CRF12-like BF recombinants (Figure 1A), despite the fact that both B and BF samples were obtained from patients experiencing therapy failure. Interestingly, the decline in HIV-1 cases in Argentina was not observed among heterosexuals [Boletín sobre el SIDA en la República Argentina, 16], a trend that can be observed in Figure 1B. While subtype B declined in growth and fitness since 1996, CRF12-like viruses continued to grow with higher fitness, spread by heterosexual and IDU contacts [18] until today [19]. Our findings are important because they constitute an unique record of the turning point, when $\mathrm{BF}$ recombinants started to prevail over subtype $\mathrm{B}$, a recurrent pattern in Brazil as well [20].

In sum, perhaps BF became the most common HIV-1 in Argentina, not only because it exploited a different risk group than subtype B, but also because it was less vulnerable to the introduction of HAART in 1996. Moreover, the decline of subtype B we observed coincided with a reduction in MSM transmission cases after introduction of HAART [Boletín sobre el 
SIDA en la República Argentina, 16]. Some aspects of the subtype F protease, such as its

support our claims. Furthermore, $80 \%$ of the proteases found in BF are of subtype F [23].

Despite the recent decline in CRF12 prevalence, it has spawned a mob of new recombinants that became responsible for $85 \%$ of children infections [19], while BF recombinants coming out of South America are now being isolated elsewhere in the world [24,25].

\section{Funding}

AI and PZ have FAPESP scholarships, PZ hold CNPq scholarship, and CF has a CAPES scholarship. This study was financed in part by the viral genetic diversity program (VGDN) and FAPESP project 10/193414.

\section{References}

1. Avila MM, Pando MA, Carrion G, Peralta LM, Salomon H, et al. (2002) Two HIV-1 epidemics in Argentina: different genetic subtypes associated with different risk groups. J Acquir Immune Defic Syndr 29: 422-426.

2. Rossi D, Pawlowicz MP, Rangugni V, Singh DZ, Goltzman P, et al. (2006) The HIV/AIDS epidemic and changes in injecting drug use in Buenos Aires, Argentina. Cad Saude Publica 22: 741-750.

3. Ou CY, Takebe Y, Weniger BG, Luo CC, Kalish ML, et al. (1993) Independent introduction of two major HIV-1 genotypes into distinct high-risk populations in Thailand. Lancet 341: 1171-1174.

4. Aulicino PC, Holmes EC, Rocco C, Mangano A, Sen L (2007) Extremely rapid spread of human immunodeficiency virus type $1 \mathrm{BF}$ recombinants in Argentina. J Virol 81: 427-429.

5. de los Angeles Pando M, Maulen S, Weissenbacher M, Marone R, Duranti R, et al. (2003) High human immunodeficiency virus type 1 seroprevalence in men who have sex with men in Buenos Aires, Argentina: risk factors for infection. International Journal of Epidemiology 32: 735-740.

6. Schultz AK, Zhang M, Bulla I, Leitner T, Korber B, et al. (2009) jpHMM: Improving the reliability of recombination prediction in HIV-1. Nucleic Acids Research 37: W647W651.

7. Schultz AK, Zhang M, Leitner T, Kuiken C, Korber B, et al. (2006) A jumping profile Hidden Markov Model and applications to recombination sites in HIV and HCV genomes. BMC Bioinformatics 7: 265.

8. Carr JK, Avila M, Gomez Carrillo M, Salomon H, Hierholzer J, et al. (2001) Diverse BF recombinants have spread widely since the introduction of HIV-1 into South America. AIDS 15: F41-47. 
9. Drummond AJ, Rambaut A (2007) BEAST: Bayesian evolutionary analysis by sampling trees. BMC Evol Biol 7: 214.

10. Minin VN, Bloomquist EW, Suchard MA (2008) Smooth Skyride through a Rough Skyline: Bayesian Coalescent-Based Inference of Population Dynamics. Molecular Biology and Evolution 25: 1459-1471.

11. Drummond AJ, Ho SY, Phillips MJ, Rambaut A (2006) Relaxed phylogenetics and dating with confidence. PLoS Biol 4: e88.

12. Mikhail M, Wang B, Lemey P, Beckthold B, Vandamme AM, et al. (2005) Role of viral evolutionary rate in HIV-1 disease progression in a linked cohort. Retrovirology 2: 41.

13. Rambaut A, Drummond AJ (2007) Tracer v1.5. Available from http://beastbioedacuk/Tracer.

14. Bastos FI, Caceres C, Galvao J, Veras MA, Castilho EA (2008) AIDS in Latin America: assessing the current status of the epidemic and the ongoing response. Int $\mathrm{J}$ Epidemiol 37: 729-737.

15. Dilernia DA, Jones LR, Pando MA, Rabinovich RD, Damilano GD, et al. (2011) Analysis of HIV type $1 \mathrm{BF}$ recombinant sequences from South America dates the origin of CRF12_BF to a recombination event in the 1970s. AIDS Res Hum Retroviruses 27: 569-578.

16. (2002) Boletín sobre el SIDA en la República Argentina. Buenos Aires: Ministry of Health, National AIDS Program, August 2002. Retrieved from: http://www.msal.gov.ar/sida/boletines-anteriores.html.

17. Hartl DL, Clark AG (1989) Principles of population genetics. Sunderland, Mass.: Sinauer Associates. xiii, 682 p. p.

18. Pando MA, Gomez-Carrillo M, Vignoles M, Rubio AE, dos Ramos Farias MS, et al. (2011) Incidence of HIV type 1 infection, antiretroviral drug resistance, and molecular characterization in newly diagnosed individuals in Argentina: A Global Fund Project. AIDS Res Hum Retroviruses 27: 17-23.

19. Aulicino PC, Bello G, Guimaraes ML, Ruchansky D, Rocco C, et al. (2011) Longitudinal analysis of HIV-1 BF1 recombinant strains in vertically infected children from Argentina reveals a decrease in CRF12_BF pol gene mosaic patterns and high diversity of BF unique recombinant forms. Infect Genet Evol 11: 349-357.

20. Teixeira D, Munerato P, Komninakis SC, Fusuma EE, Janini LM, et al. (2010) The detection of in vivo and in vitro HIV type $1 \mathrm{~B} / \mathrm{F}$ profiles in Brazil using a real-time PCR assay for five HIV type 1 genomic regions. AIDS Res Hum Retroviruses 26: 981-990.

21. Krauchenco S, Martins NH, Sanches M, Polikarpov I (2009) Effectiveness of commercial inhibitors against subtype F HIV-1 protease. Journal of Enzyme Inhibition and Medicinal Chemistry 24: 638-645.

22. Sanches M, Krauchenco S, Martins NH, Gustchina A, Wlodawer A, et al. (2007) Structural characterization of B and non-B subtypes of HIV-protease: insights into the natural susceptibility to drug resistance development. J Mol Biol 369: 1029-1040.

23. Petroni A, Deluchi G, Pryluka D, Rotryng F, Bortolozzi R, et al. (2006) Update on primary HIV-1 resistance in Argentina: emergence of mutations conferring high-level resistance to nonnucleoside reverse transcriptase inhibitors in drug-naive patients. J Acquir Immune Defic Syndr 42: 506-510.

24. Bruselles A, Rozera G, Bartolini B, Prosperi M, Del Nonno F, et al. (2009) Use of massive parallel pyrosequencing for near full-length characterization of a unique HIV Type $1 \mathrm{BF}$ recombinant associated with a fatal primary infection. AIDS Res Hum Retroviruses 25: 937-942. 
25. Gonzalez-Alba JM, Holguin A, Garcia R, Garcia-Bujalance S, Alonso R, et al. (2011) Molecular surveillance of HIV-1 in Madrid, Spain: a phylogeographic analysis. J Virol 85: 10755-10763. 
Figure 1 - Demographic reconstructions for subtype B and CRF12-like samples from

Argentina. (A) Growth for each virus group (B and CRF12-like) and (B), absolute fitness $\left(w_{a b s}\right)$ since 1980 and the number of HIV cases in Argentina according to risk behavior [Boletín sobre el SIDA en la República Argentina, 16]. The dashed line marks a constant growth $\left(w_{a b s}=1\right)$, values of $w_{a b s}$ above the line indicate net growth of viral infections in time, and values under the line represent a decline in growth. Free antiretroviral (ARV) therapy and highly active antiretroviral therapy (HAART) introduction in Argentina are both marked by vertical arrows.

Supplementary Figure 1 - Recombination breakpoints and haplotypes. A genome map of HIV-1 pol gene marked according to HXB2, showing subtype B (blue) and F1 (green) portions of the major haplotypes found. Uncertainty regions are shown in blue and green.

\author{
Supplementary Figure 2 - Demographic reconstructions for subtype B (A) and CRF12- \\ like (B) samples from Argentina. A GRMF Bayesian skyride plot of the variation over the \\ years of the $\log 10$ of the effective population size (Ne.g, that is proportional to the number \\ of infections times generation time), obtained from three independent MCMC runs, each \\ consisting of 50 million generations.
}

Supplementary Table - Recombination breakpoints and haplotype. A complete list of patient codes and the recombination pattern estimates according to jpHMM. 
Figure 1

Click here to download high resolution image

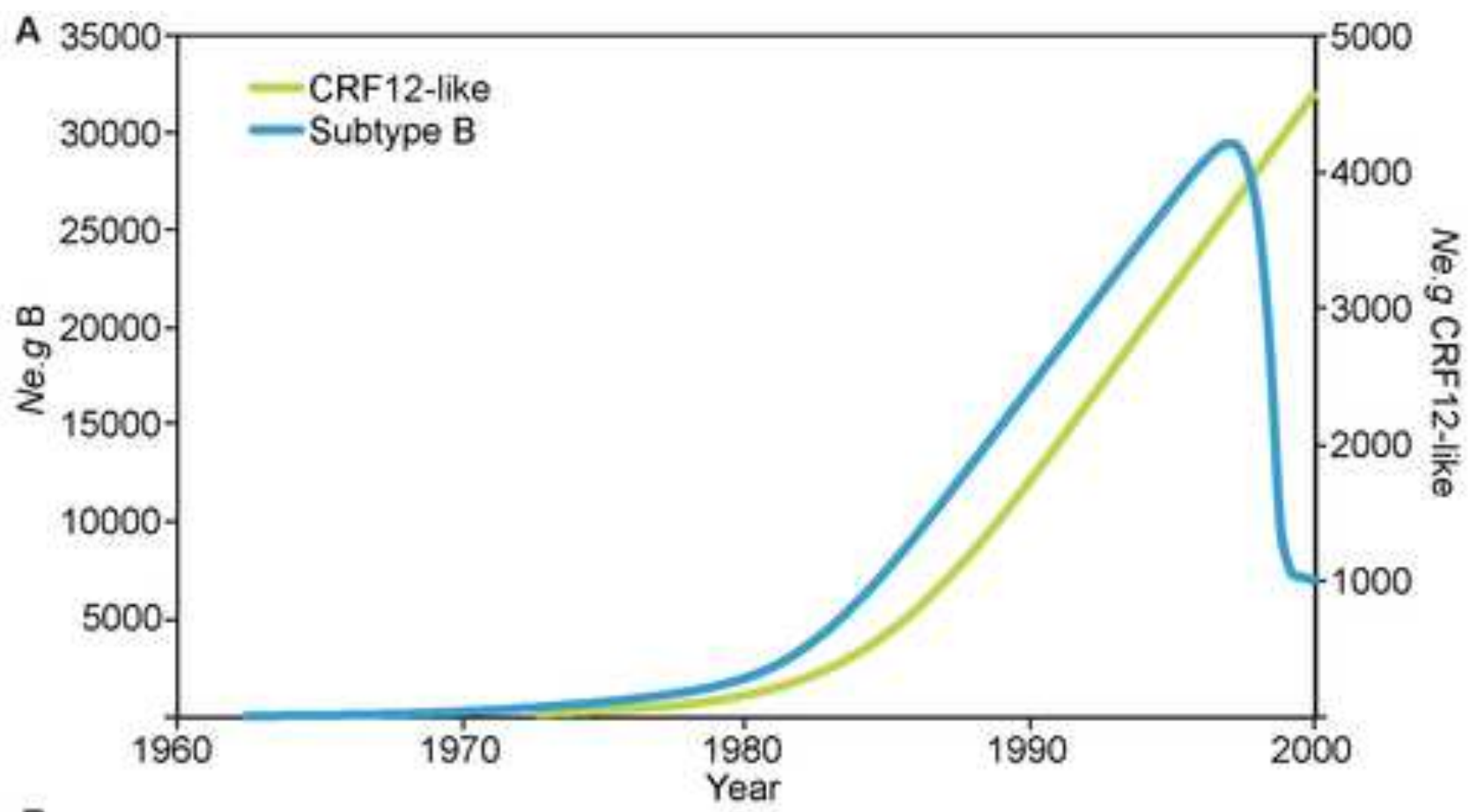

B

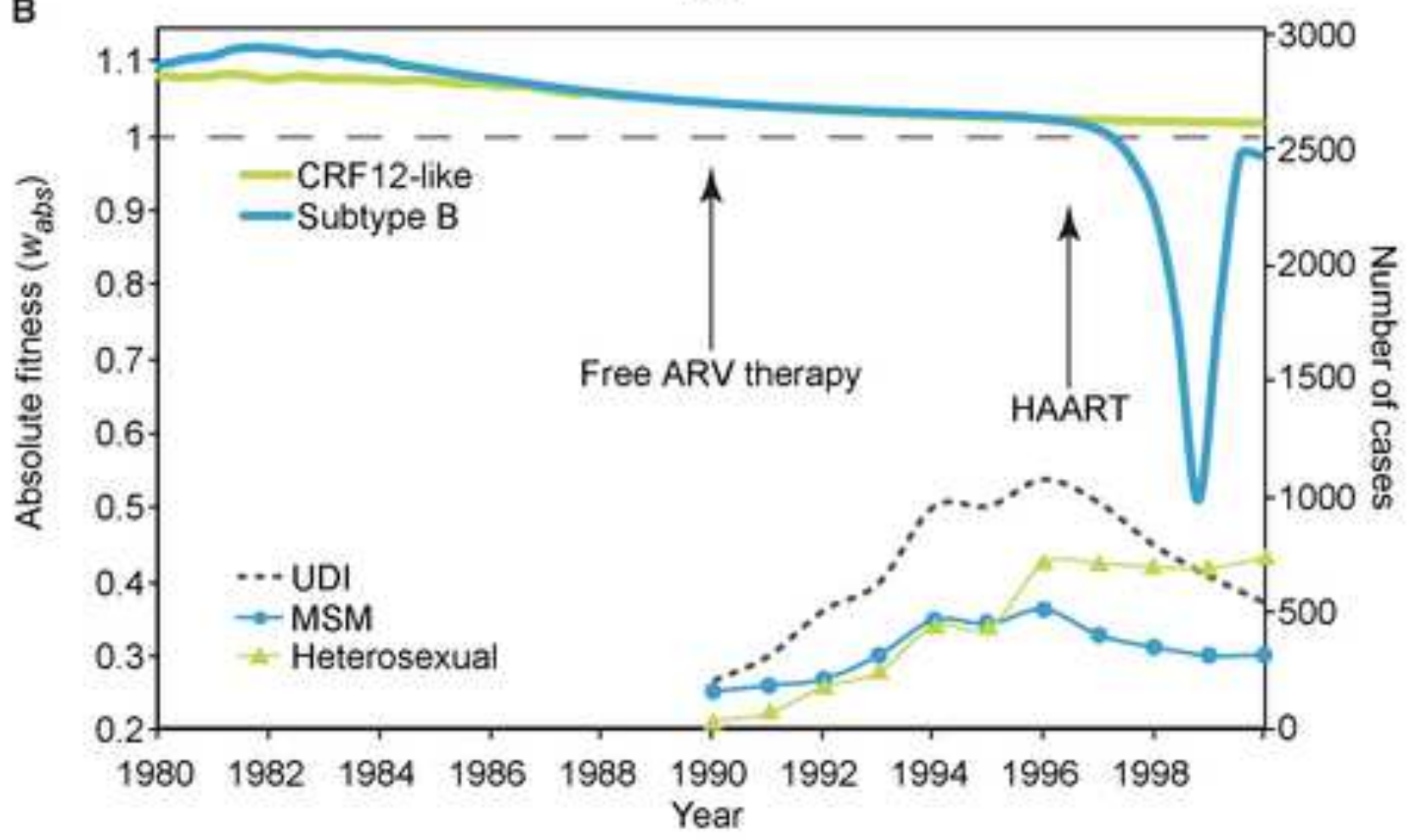


Viruses 2011, 3, 1-x manuscripts; doi:10.3390/v30x000x

\title{
viruses
}

ISSN 1999-4915

www.mdpi.com/journal/viruses

Article

\section{A comparative structural analysis of HIV-1 proteases of subtypes $B$ and $F$ on Nelfinavir resistance.}

\author{
Atila Iamarino $^{1 *}$ and Paolo Marinho de Andrade Zanotto ${ }^{1}$ \\ ${ }^{1}$ Laboratory of Molecular Evolution and Bioinformatics, Department of Microbiology, Biomedical \\ Sciences Institute - ICBII, University of São Paulo / Av. Prof. Lineu Prestes, 1734 - ICBII, \\ University of São Paulo, Sao Paulo, SP, Brazil. ZIP: 05508-000
}

E-Mails: atila@usp.br (A. I.); pzanotto@usp.br (P. Z.)

* Author to whom correspondence should be addressed; Tel.: +55-11-3091-8453

Received: / Accepted: / Published:

\begin{abstract}
Despite efforts to control HIV-1 infection, the large diversity of recombinant forms has increased among infected people. In Brazil, many recombinant viruses have been detected, mainly between subtypes B and F. During the Viral Genetic Diversity Network (VGDN) program, a number of recombinant viruses were found in São Paulo State (Brazil). Most of the recombinants found have a BF origin and have predominantly an $\mathrm{F}$ protease. This finding is in line with structural data from $\mathrm{F}$ proteases showing that characteristic $\mathrm{F}$ subtype polymorphisms may facilitate PI resistance. This study focus on the in silico structural modeling and simulating the interactions between subtype $\mathrm{B}, \mathrm{BF}$, and $\mathrm{F}$ proteases that carry similar primary resistance mutations to Nelfinavir, which was the main inhibitor used by these patients. Our data suggests that the same primary mutations that diminish affinity in subtype B proteases have a greater effect in subtype F affinity for Nelfinavir, possibly even restoring wild-type protease activity. This finding provides a structural basis for the observation that F proteases are naturally more resistant to PI.
\end{abstract}

Keywords: HIV-1 protease; HIV-1 subtype diversity; Nelfinavir resistance. 


\section{Introduction}

AIDS related deaths declined since 2004, mainly due to the success of highly active antiretroviral therapy (HAART) [1]. This caused an increasing number of individuals depending on antiretroviral therapy (ART) for survival. Brazil started distributing AZT through its national healthcare system in 1991. As early as 1996, protease inhibitors (PIs) and ART were made universally available, with a reported coverage of around $100 \%$ of the patients [2]. As a consequence, a decrease in AIDS patients deaths since HAART introduction in 1996 was observed in Brazil [3], and as of 2010, 190 thousand patients were under ART [4].

Under ART, the HIV incorporates mutations that diminish the drug efficiency. Nevertheless, drug resistance mutations have a negative impact on viral fitness [5], and are followed by secondary (i.e., compensatory) mutations, which tend to restore viral fitness. HIV-1 antiviral drugs show activity against all subtypes, despite having been developed based on subtype B viruses. Moreover, resistance mechanisms may vary according to viral subtype and the adopted treatment [6].

Subtype B HIV-1 is still the most prevalent in Brazil, followed by subtype C in the country's southern region $[7,8]$ and $\mathrm{BF}$ recombinants $[9,10,11]$. A similar increase of other types of $\mathrm{BF}$ recombinants took place in Argentina, showing that the generation of recombinant forms is a recurrent event, resulting from the entry of distinct HIV lineages in places where subtype B was previously dominant [12]. Moreover, subtype B and BF recombinants show different mutational frequencies mainly in the protease gene, as suggested by an analysis of 583 Argentinean sequences [13]. None of the polymorphisms, which discriminate subtype B from F, take place in protease portions that are in direct contact with the substrate, which rather fall at sites related to frequent secondary mutations that restore enzymatic activity. As a consequence, all PIs have lower efficiency against subtype F proteases [14].

The HIV-1 protease is a homodimer composed of two 99 amino acids monomers. It is classified as an aspartic-protease and has a catalytic triad formed by three amino acids: aspartic acid 25, threonine 26 and glycine 27. It is highly flexible with water molecules mediating most interactions with substrate and between monomers. Substrate binding occurs through flexible regions called flaps [15], composed of amino acids 33 to 62, which provide a stable contact with substrate proteins [16]. Several in silico simulations demonstrated that proteases sporting resistance-associated mutations have a smaller affinity for PIs [17], while resistant proteases also appear to carry important structural differences at flaps and binding sites [18].

Previous molecular dynamics studies focusing on protease resistance have looked at artificially generated sequences that consist in replacing target amino acids in a common backbone [19, 20, 21]. Although elucidative, these studies miss biologically meaningful secondary mutations necessary for enzymatic activity restoration and may generate amino acid combinations that do not arise in vivo. To avoid this bias, we focused on modeling and simulating naturally occurring sequences obtained from patients included in the VGDN study [22], comparing subtypes B, BF, and F proteases sharing the 
same primary resistance mutations. For this purpose, we used a method that facilitates molecular dynamics simulations by measuring protein affinity for ligands via free binding energy estimation through the time-efficient linear interaction energy, or LIE [23]. Herein we access differences caused by subtype F-specific polymorphisms in the interaction of the HIV-1 protease to Nelfinavir that is one of the most important PIs used in Brazil at the time those patients were studied and sampled [24].

\section{Results and Discussion}

Subtype B and subtype F proteases with similar primary drug resistance mutations were simulated and compared, to access the effect of these mutations on different genomic backbones. Wild-type subtype F protease (named CtrlF hereafter) had less $\alpha$-carbon root mean square fluctuation (RMSF) in general (Figure 1). Moreover, a remarkable difference in the affinity to Nelfinavir was measured in CtrlF that had a low binding energy, similar to proteases with primary resistance mutations (Table 1). As suggested by Sanches, 2007 [25], the presence of M36I and L89M, natural polymorphisms of nonsubtype B HIV-1 proteases has a large impact in inhibitor interaction at the active site. The M36I polymorphism is located at the hinge of the flap, impairing its flexibility [26] and may favor Nelfinavir resistance when succeeded by primary mutations [27], especially in non-B subtypes [28]. This was made evident by a smaller fluctuation of the flaps in general, except for amino acids 49 and 50 (Figure 1 and Supplementary Figure 1). The L89M mutation is also present in protease CtrlF, and its effect is suggested to be analogous to L90M, displacing the active site and constraining the S1/S1' binding pockets [26]. Both mutations may have contributed to subtype $\mathrm{F}$ decrease in affinity for Nelfinavir, as shown by the RMSF in P1, P2 and P2' (Figures 2 and 3). Another remarkable distinction was observed, when the smaller number of hydrogen bonds between the catalytic amino acid D25 and substrate (Table 1) was unmistakably different from subtype B wild-type (named CtrlB hence forth). 
Figure 1 - $\alpha$-carbon root mean square fluctuation (RMSF) of proteases in comparison to CtrlB from 4ns to 10ns of simulation. The proteases were colored according to the RMSF difference per $\alpha$-carbon in comparison to the corresponding residue in CtrlB, from a minimum of $-0.1 \mathrm{~nm}$ (dark blue) to a maximum of $0.2 \mathrm{~nm}$ (red). Proteases were grouped according to resistance-associated mutations (yellow dots). (a) Proteases carrying G48V, I54T/V and V82A mutations. (b) Proteases carrying M46I/L and V82A mutations. (c) Proteases harboring I54V and L90M mutations.

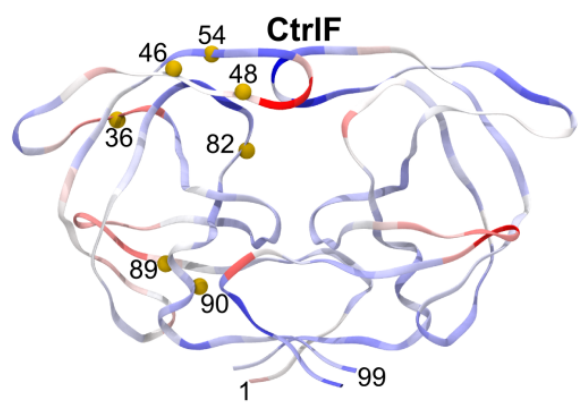

A 1120
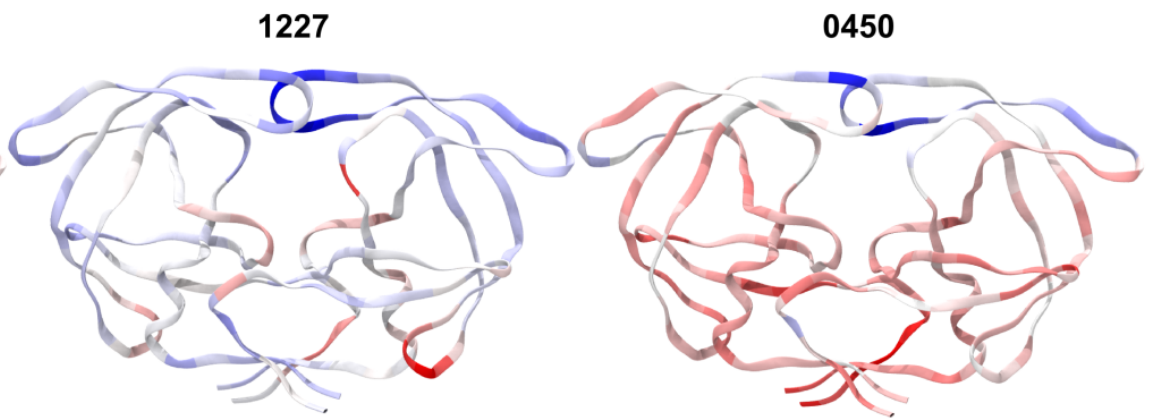

B
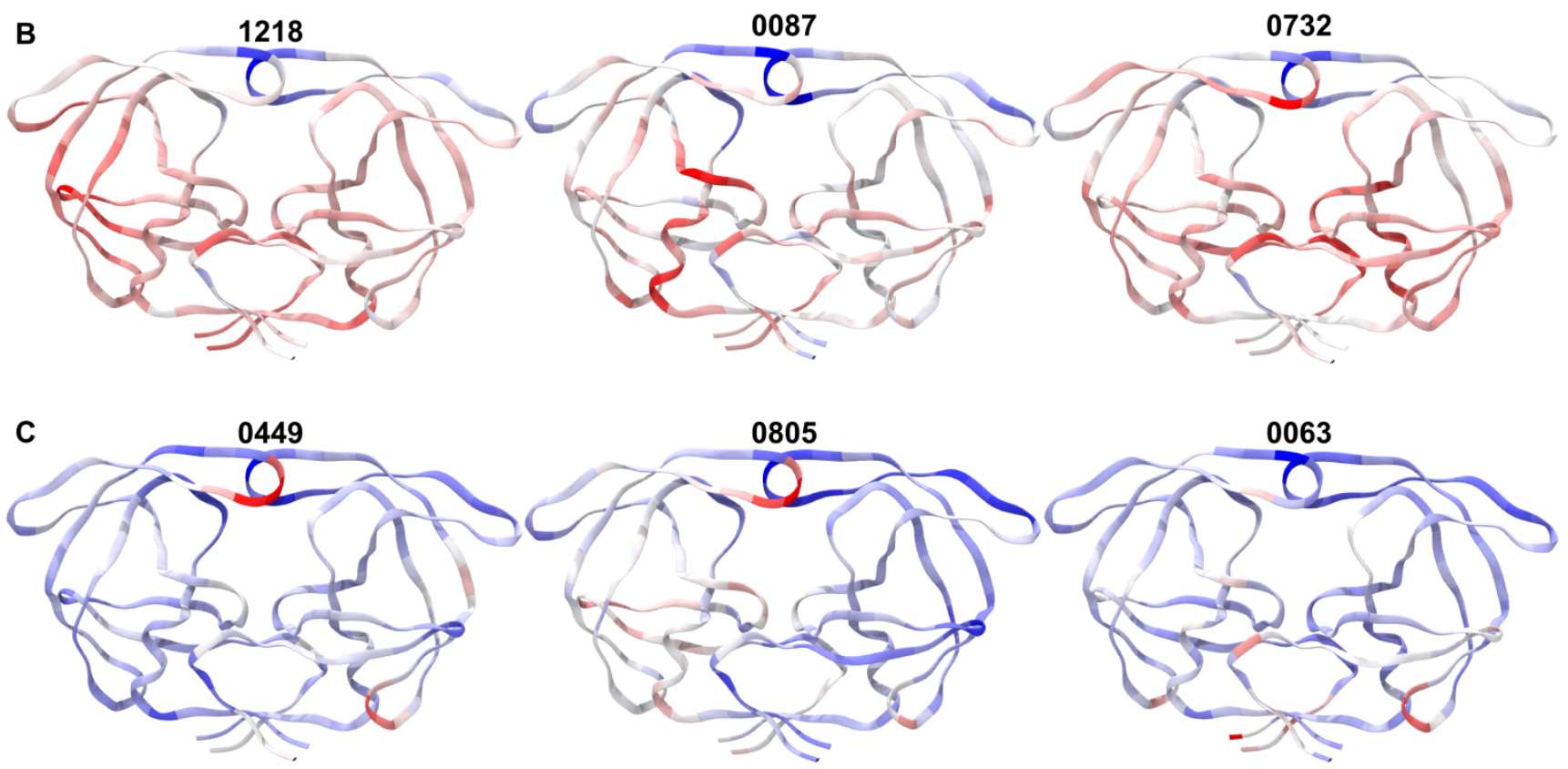
Figure 2 - Root mean square fluctuation (RMSF) of the individual atoms of Nelfinavir. Regions P2, P1, P1', P2' and individual atoms are outlined above. The columns highlight colors indicate atom type, carbon in light blue, nitrogen in dark blue, oxygen in red, sulfur in yellow and hydrogen in white. Subtype B (blue) and subtype F (red) proteases were grouped according to resistance associated mutations. (a) Proteases carrying G48V, I54T/V and V82A mutations. (b) Proteases harboring M46I/L and V82A mutations. (c) Proteases carrying I54V and L90M mutations. 

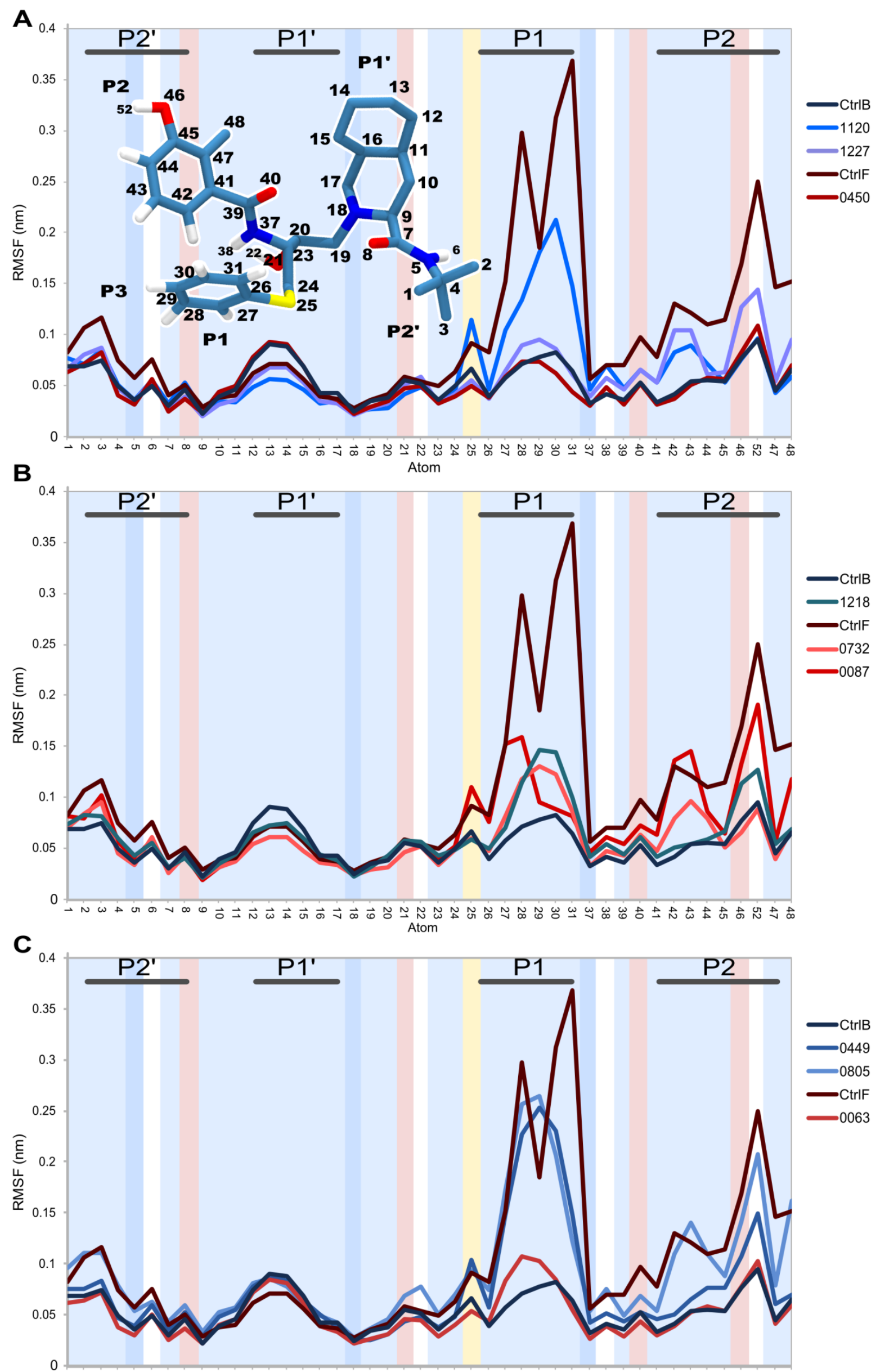
Figure 3 - Fluctuation of Nelfinavir after 4 nanoseconds of simulation. Snap shots taken at every 100ps during the simulation show that Nelfinavir molecules display different conformations of P1 region (shown by arrow). The molecules were grouped according to resistance-associated mutations. (a) Proteases carrying G48V, I54T/V and V82A mutations. (b) Proteases carrying M46I/L and V82A mutations. (c) Proteases carrying I54V and L90M mutations.
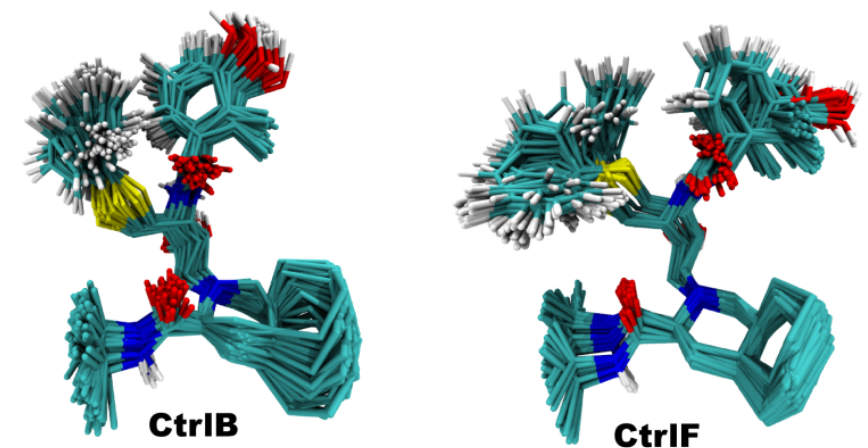

A
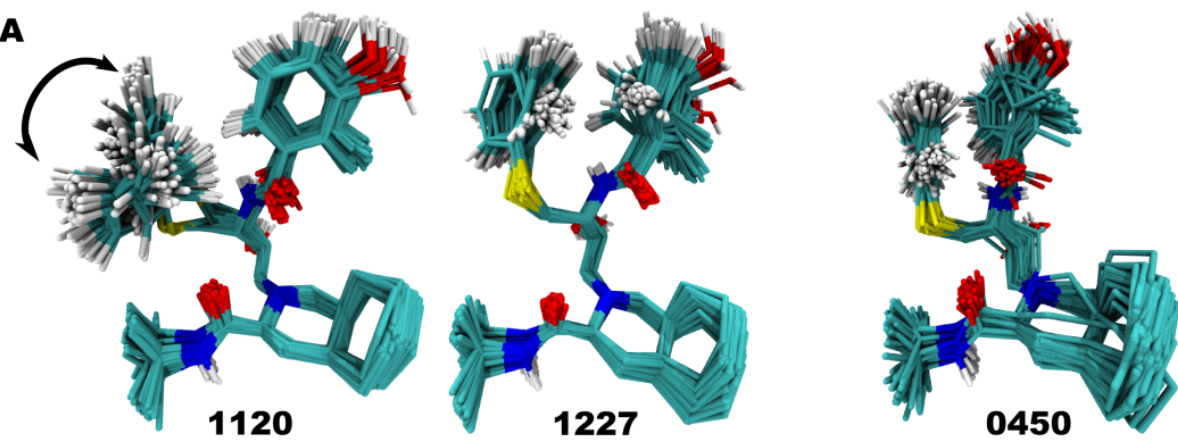

B
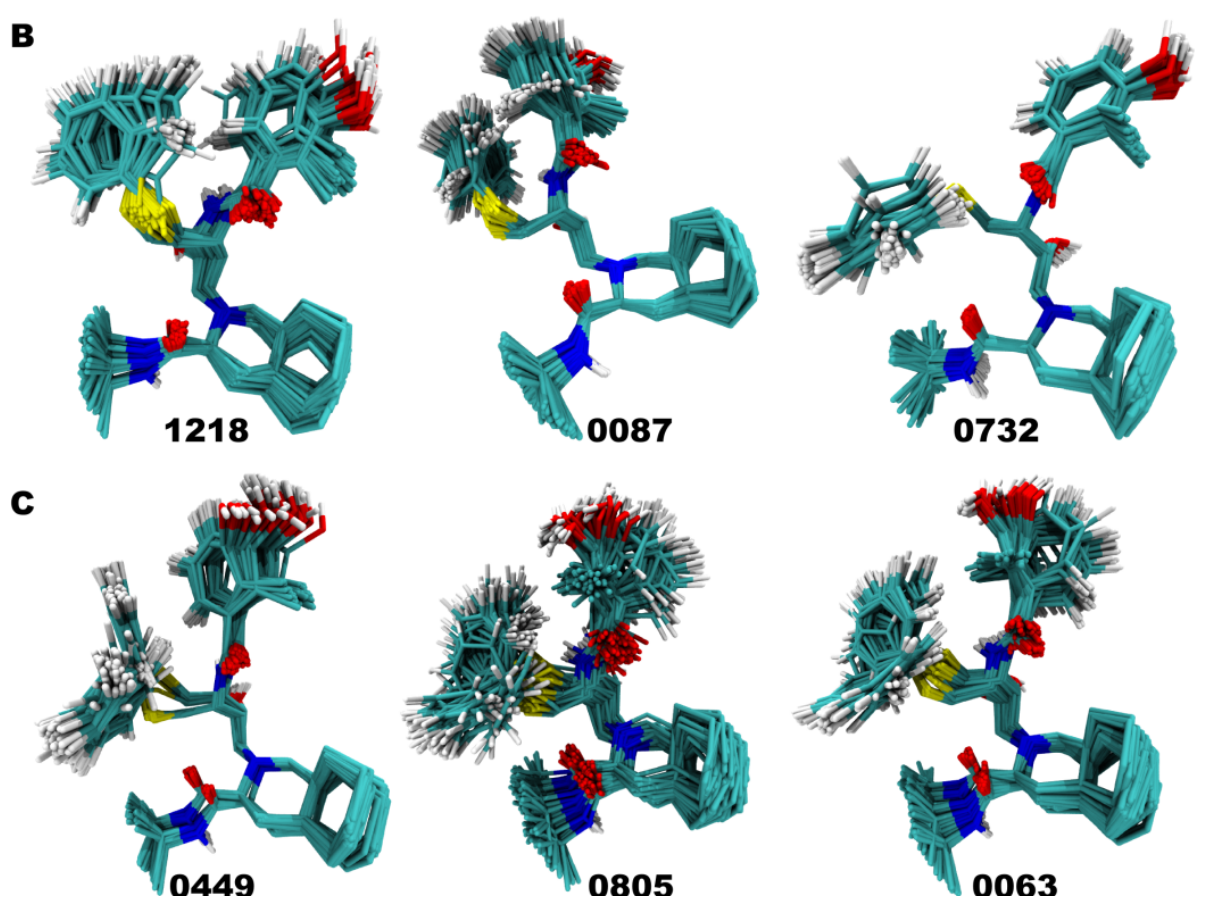
Table 1. Molecular dynamics parameters measured after $4 \mathrm{~ns}$ of simulation. Flap distance corresponds to the average root mean square fluctuation (RMSF) in nm fluctuation in the distance between the $\alpha$-carbon of Ile50 from the flap tip and the $\beta$-carbon of Asp25 of the respective chain. Hydrogen bonds correspond to the average of bonds made between Nelfinavir and Asp25. And binding represents the estimated binding free energy of Nelfinavir and the protease active site. Subtype F proteases are highlighted in grey.

\begin{tabular}{|c|c|c|c|c|c|c|c|c|c|}
\hline \multirow{2}{*}{\multicolumn{2}{|c|}{ Mutations }} & \multicolumn{3}{|c|}{ Flap distance } & \multicolumn{4}{|c|}{$\mathrm{H}$ bonds } & \multirow{2}{*}{$\begin{array}{c}\text { Binding } \\
\Delta \mathrm{G} \mathrm{KJ} / \mathrm{mol} \\
\end{array}$} \\
\hline & & \multicolumn{2}{|c|}{ Asp25 - lle 50} & Asp25' - Ile50' & \multicolumn{2}{|c|}{ Asp25 } & \multicolumn{2}{|c|}{ Asp25 } & \\
\hline & Control B & $1,31=$ & $\pm 0,05$ & $1,74 \pm 0,09$ & 1,93 & $\pm 0,49$ & $0,06=$ & $\pm \quad 0,24$ & $-44,02 \pm 8,67$ \\
\hline & Control F & $1,35=$ & $\pm 0,08$ & $1,71 \pm 0,05$ & 1,00 & $\pm 0,14$ & $0,12=$ & $\pm 0,33$ & $-27,04 \pm 7,87$ \\
\hline \multirow{3}{*}{$\begin{array}{r}\text { G48V, I54T } \\
\text { and V82A } \\
\end{array}$} & 1120 & $1,55=$ & $\pm 0,01$ & $1,82 \pm 0,06$ & 1,61 & $\pm 0,61$ & $0=$ & $\pm 0,07$ & $-30,77 \pm 9,7$ \\
\hline & 1227 & $1,35=$ & $\pm 0,05$ & $1,74 \pm 0,05$ & 1,09 & $\pm 0,39$ & $0,22=$ & $\pm 0,41$ & $-29,66 \pm 8,47$ \\
\hline & 0450 & $1,30=$ & $\pm 0,05$ & $1,80 \pm 0,09$ & 1,73 & $\pm 0,51$ & $0,2=$ & $\pm 0,41$ & $-32,08 \pm 7,53$ \\
\hline \multirow{3}{*}{$\begin{array}{c}\text { M46L and } \\
\text { V82A }\end{array}$} & 1218 & $1,44=$ & $\pm 0,06$ & $1,72 \pm 0,04$ & 0,01 & $\pm 0,08$ & 1 & $\pm 0,03$ & $-32,55 \pm 7,27$ \\
\hline & 0087 & 1,32 & $\pm \quad 0,05$ & $1,77 \pm 0,06$ & 1 & $\pm 0,14$ & $0,84=$ & $\pm 0,36$ & $-20,09 \pm 8,73$ \\
\hline & 0732 & 1,63 & $\pm 0,11$ & $1,78 \pm 0,05$ & 1,17 & $\pm 0,43$ & $0,14=$ & $\pm \quad 0,35$ & $-22,85 \pm 7,19$ \\
\hline \multirow{3}{*}{$\begin{array}{l}\text { I54V and } \\
\text { L90M }\end{array}$} & 0449 & 1,46 & $\pm 0,18$ & $1,72 \pm 0,05$ & 1,64 & $\pm 0,53$ & $0,88=$ & $\pm 0,57$ & $-39,34 \pm 8,36$ \\
\hline & 0805 & 1,45 & $\pm 0,14$ & $1,59 \pm 0,1$ & 1,13 & $\pm 0,38$ & $0,04=$ & $\pm 0,20$ & $-34,3 \pm 9,09$ \\
\hline & 0063 & $1,28=$ & $\pm 0,04$ & $1,73 \pm$ & 1,92 & $\pm 0,32$ & $0,04=$ & $\pm \quad 0,19$ & $-31,64 \pm 6,87$ \\
\hline
\end{tabular}

\subsection{G48V, I54T/V and V82A Mutations}

Proteases from subtype F from patient 0450 and subtype B from patients 1227 and 1120 were used for comparing subtype-specific polymorphisms. All three proteases $(0450,1227$ and 1120) came from patients not exposed to Nelfinavir but that were subjected to other PIs for an extended period of time during ART (see Experimental Section for patients regimens). Proteases 0450 and 1227 share the same primary mutations, while protease 1120 does not have the G48V mutation. G48V and I54T are located at the hinges of the flaps and have an important role on flap flexibility and substrate binding through hydrophobic interactions [29]. The lack of G48V mutation in protease 1120 may account for the overall larger fluctuation at the flaps (figure 1) and distance between D25 and I50 (Table 1), as well as a greater influence of V82A. Actually, V82A mutation introduces a smaller alanine side chain generating an asymmetry between $\mathrm{S} 1$ and S1' subsites [30], expanding the cavity were Nelfinavir P1 region is located. This asymmetry was evidenced by the difference in the RMSF of S1/S1' regions (Supplementary Figure 1) and the ligand P1 and P1' regions (Figure 3), which adopted different conformations during the protease 1120 dynamics. Notwithstanding the lower binding affinity similar to proteases 1227 and 1120, subtype F protease 0450 had a Nelfinavir fluctuation similar to CtrlB, and a smaller fluctuation at S1 and S1' regions (Supplementary Figure 1). It remains unclear if the I72V mutation could cause the different proprieties of protease 1227 , such as residues 63 to 67 RMSF measured in chain $\mathrm{B}$, in spite of the fact that mutations at structurally important sites caused conformational changes in the whole protease, such as the surroundings of residue 73. 


\subsection{M46I/L and V82A Substitutions}

Subtype B protease 1218 was used for comparing M46L and V82A mutations of subtype F proteases 0087 and 0732 . Protease 1218 was the only one from subtype B that was found among VGDN patients harboring this combination of mutations. Mutation M46L is situated at the beginning of the first glycine-rich $\beta$-sheet that forms the flap, altering the flap flexibility and decreasing enzymatic activity while acting synergistically with I54T and V82A increasing PI resistance [31]. Its presence in subtype $\mathrm{F}$ proteases seems to increase the influence of V82A in both S1/S1' and S2/S2' fluctuations (Supplementary Figure 1), as well as at Nelfinavir P1 and P2 regions (Figure 3), decreasing significantly the binding free energy when compared to CtrlB and protease 1218 (Table 1).

\subsection{I54V and L90M substitutions}

The L90M mutation is particularly interesting because it is usually not found among subtype $\mathrm{F}$ proteases, while L89M is a common polymorphism in non-B subtypes. Remarkably, the simultaneous presence of both L89M and L90M is associated with a decrease in subtype F protease fitness [32]. This is a possible reason why protease 0063 has L89I and not $89 \mathrm{M}$ together with L90M. Subtype F protease 0063 was compared to two subtype B proteases 0449 and 0805 carrying L90M. The two subtype B proteases had a larger fluctuation at the flaps (Figure 1) and Nelfinavir P1 region (Figure 2), similar to CtrlF. The subtype B protease 0805 had a combination of resistance mutations (M46I, I54V, V82A and L90M), which is expected to greatly reduce Nelfinavir affinity. Nevertheless, subtype F protease 0063 had a similar reduced affinity (Table 1), despite its flap distances, hydrogen bonds and Nelfinavir fluctuations that resembled CtrlB.

\subsection{Overall differences between Subtype B and Subtype F proteases}

Well-characterized in vivo associations of mutation-associated changes in subtype B do not appear to happen on other HIV-1 subtype proteases. For example, L90M followed by I54V causes an increase in resistance in subtype B protease, while not in subtype G proteases [33]. On the other hand, L89I increases resistance in subtype $G$ but not in subtype $B$, demonstrating a significant role of the genetic background in which specific changes take place [33]. Likewise, the compensatory effect caused by the M36I mutation in resistant proteases is specific to subtypes C and CRF02_AG, and was not detected on subtype B [28]. This fact justifies our study of $\mathrm{F}$ proteases found in both $\mathrm{F}$ and $\mathrm{BF}$ viruses circulating among our population. Moreover, the protease CtrlF had an important loss in Nelfinavir affinity, larger than that observed on some subtype B resistant proteases.

Our modeling exercise unveiled two interesting types of mutations in terms of their impact. Some subtype B well characterized primary resistance mutations were associated with lower binding affinities to Nelfinavir in F proteases, such as M46L and V82A effects on 0087 and 0732 when compared to subtype B protease 1218. Remarkably, patient 0732, a male heterosexual with an HIV+ partner had never been treated with PIs but was probably infected with a PI resistant virus. The presence of a resistance mutation M46L that reduces protease activity [30] after at least 10 months (estimated from the dates of the patients first HIV+ result in December of 2002 and the sampling date 
in October of 2003) may imply some form of rescue of functional capacity, possibly due to compensatory mutations.

On the other hand, we also found subtype F proteases carrying mutations that appear not to decrease binding affinities, which we assume to be indicative of a higher vitality (that is, the capacity of an enzyme to maintain activity under mutation). For example, mutations G48V, I54T and V82A, and L90M effects on subtype F proteases 0450 and 0063 had flap distances and hydrogen bonds similar to CtrlB while maintaining the smaller binding affinity to Nelfinavir. Similarly to the differences observed between subtypes $\mathrm{G}$ and $\mathrm{B}$ proteases [33], we argue that the differences among subtypes $\mathrm{F}$ and $\mathrm{B}$ could be a consequence of F-defining polymorphisms that are present on $\mathrm{F}$ proteases before the accumulation of primary resistance mutations. This notion is supported by both our findings that CtrlF had one of the lowest affinities for Nelfinavir and that protease 0732 retained important primary resistance mutations for months in an untreated patient. Our findings are in line with the fact that subtype B has a lower vitality when exposed to Nelfinavir than AE variants [34]. Moreover, BF CRF forms with $\mathrm{F}$ protease show a high rate of growth rate in Argentina [35] and Uruguay [36] which would be explained to some extent by a higher F proteases vitality.

\section{Experimental Section}

In order to compare the influence of polymorphisms and secondary mutations on PI resistance, subtype F, B, and BF protease sequences were chosen from patients included in the VGDN study [22]. The sequences were analyzed with the jumping profile hidden Markov model (jpHMM) program [37, 38] to determine recombination profiles. Drug resistance mutations were genotyped using the HIV Drug Resistance Database [39, 40]. Two subtype F (0087 and 0450) and two BF recombinant viruses (0063 and 0732) had subtype F proteases with Nelfinavir primary resistance mutations M46I/L, G48V, I54V, V82A and L90M. The protease 0063 is derived from a CRF29-like virus and has the last five amino acids form subtype B. Subtype F protease resistance associated mutations and polymorphisms are shown in Appendix 1A. Seven subtype B proteases: five from subtype B viruses $(0015,0805$, 0947, 1218 and 1227) and two from BF recombinants (0449 and 1120) were used to compare similar major resistance mutations and relevant polymorphisms from subtype $\mathrm{F}$ and $\mathrm{BF}$ proteases. Mutation M46L was not found in subtype B proteases. Subtype B protease resistance associated mutations and polymorphisms in our samples are shown in Appendix 1B. Patient drug regimens that included protease inhibitors are shown in Appendix 1C.

\subsection{Homology Modeling and Molecular Dynamics}

Protease models were built based on X-ray crystallographic structure of HIV-1 subtype B wild-type protease complexed with Nelfinavir (1OHR) [41], including water molecules, with the homology modeling method and MODELLER software [42]. Protease 1OHR was also used as subtype B control. A subtype F wild-type protease (2P3C), which carries the mutations I15V, E35D, M36I, S37A, R41K, R57K, D60E, Q61N, I62V, L63S, I64L, and L89M, was used as control for subtype F [26]. The homology-based models were validated using the Procheck [43] software. All dynamic steps were done, sampled and analyzed with the GROMACS program [44], simulations took 10ns and sampling $6 \mathrm{~ns}$. Visualizations and figures were made with the VMD program [45]. 
The aspartic acid residue protonation followed its $\mathrm{pI}$, assuming the optimum $\mathrm{pH}$ for the protease as 5 [46]. $\mathrm{Na}+$ and $\mathrm{Cl}$ - ions were added to the system in order to balance charges. This assured that the system calculation of free energy would mimic the protein functional conditions, since it requires total null charge conditions [47]. The structural refinement, avoiding steric clashes among residues and water molecules, was made by steepest descent and conjugated gradient techniques, which avoid the introduction of artificial amounts of energy into the system. The simulations were realized under GROMOS96 force field and the Reaction Field System [44].

Free energy was estimated using linear interaction energy, or LIE [23], according to equation 1 below.

$$
\Delta G_{\text {bind }}=\alpha \Delta\left\langle V_{l-s}^{v d w}\right\rangle+\beta \Delta\left\langle V_{l-s}^{e l}\right\rangle+\gamma
$$

The LIE method yields estimates that consider only the initial and final states of interaction between a ligand and its enzyme. Calculating the free energy using LIE method consists of considering the energy of ligand solvation inside the active site, which corresponds to the electrostatic energy, and the van der Waals of the active site binding [47]. Where the $\alpha$ value introduces the empirical correction factor for Leonnard-Jones force, and the $\beta$ value represents the polar atoms electrostatic interaction or Coloumb's law [47]. The $\alpha$ and $\beta$ values adopted were, respectively, 0.181 and 0.33 , according to the methodology suggested for neutral ligands or those with 2 or more $\mathrm{OH}$ groups [48, 49]. These parameters generated $\Delta \mathrm{G}$ values similar to those obtained in Saquinavir complexed proteases [46], but slightly lower to those empirically measured by calorimetry with the wild-type protease binding to Nelfinavir [20]. This similarity of parameter values allowed us to avoid a $\gamma$ correction. Only

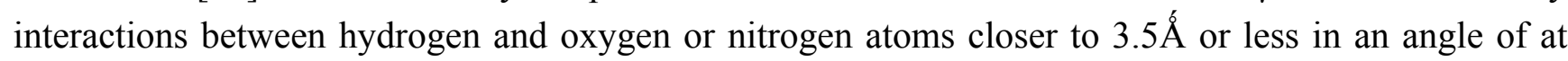
most $120^{\circ}$ were considered as meaningful hydrogen bonds.

\section{Conclusions}

Our molecular dynamics results obtained so far combined with previous studies $[14,50]$ show an important role of subtype F protease in BF recombinants and HIV epidemics in South America, where PI resistance may play a big role in selecting viruses. Both, the increase of subtype BF recombinants in South America (Iamarino et al., submitted) together with the protease dynamics we show, point to a possible selective advantage of subtype F protease. Differences in fitness could be associated to intrinsic proprieties of each protease subtype. Crucially, and in accordance to our simulations, wildtype subtype $\mathrm{F}$ protease has been demonstrated in vitro to have a background resistance to all commercial PIs [14]. The resulting effects of subtype F polymorphisms and primary resistance mutations selected by protease inhibitors should be considered carefully in future HAART schemes, especially given the amplitude of ART coverage in Brazil and elsewhere. 


\section{Acknowledgments}

We thank Pedro G. Pascutti from Laboratório de Modelagem e Dinamica Molecular, Instituto de Biofisica Carlos Chagas Filho, Universidade Federal do Rio de Janeiro for the Nelfinavir model and parameters used in simulations. AI has a FAPESP scholarship, PMAZ holds a CNPq-PQ scholarship. This study was funded by FAPESP projects 00/04205-6 (VGDN program) and 08/58559-5.

\section{Conflict of Interest}

The authors declare no conflict of interest.

\section{References and Notes}

1. UNAIDS/WHO Report on the global AIDS epidemic. http://www.unaids.org 2010, Accessed in 2011.

2. Chequer, P.; Cuchi, P.; Mazin, R.; Garcia Calleja, J.M. Access to antiretroviral treatment in Latin American countries and the Caribbean. AIDS 2002, 16 Suppl 3, S50-57.

3. Marins, J.R.; Jamal, L.F.; Chen, S.Y.; Barros, M.B.; Hudes, E.S.; Barbosa, A.A.; Chequer, P.; Teixeira, P.R.; Hearst, N. Dramatic improvement in survival among adult Brazilian AIDS patients. AIDS 2003, 17, 1675-1682.

4. Brasil, M.o.H.; Policy, N.A.d., Boletim Epidemiológico. In Brasília: Coordenação Nacional de DST e AIDS, Ministério da Saúde, 2010; Vol. VI.

5. Coffin, J.M. HIV population dynamics in vivo: implications for genetic variation, pathogenesis, and therapy. Science 1995, 267, 483-489.

6. $\quad$ Kantor, R.; Katzenstein, D.A.; Efron, B.; Carvalho, A.P.; Wynhoven, B.; Cane, P.; Clarke, J.; Sirivichayakul, S.; Soares, M.A.; Snoeck, J.; Pillay, C.; Rudich, H.; Rodrigues, R.; Holguin, A.; Ariyoshi, K.; Bouzas, M.B.; Cahn, P.; Sugiura, W.; Soriano, V.; Brigido, L.F.; Grossman, Z.; Morris, L.; Vandamme, A.M.; Tanuri, A.; Phanuphak, P.; Weber, J.N.; Pillay, D.; Harrigan, P.R.; Camacho, R.; Schapiro, J.M.; Shafer, R.W. Impact of HIV-1 subtype and antiretroviral therapy on protease and reverse transcriptase genotype: results of a global collaboration. PLoS Med 2005, 2, e112.

7. Gonsalez, C.R.; Alcalde, R.; Nishiya, A.; Barreto, C.C.; Silva, F.E.; de Almeida, A.; Mendonca, M.; Ferreira, F.; Fernandes, S.S.; Casseb, J.; Duarte, A.J. Drug resistance among chronic HIV-1-infected patients naive for use of anti-retroviral therapy in Sao Paulo city. Virus Res 2007, 129, 87-90.

8. Gupta, R.K.; Pillay, D. HIV resistance and the developing world. Int J Antimicrob Agents 2007, 29, 510-517.

9. Bello, G.; Guimaraes, M.L.; Morgado, M.G. Evolutionary history of HIV-1 subtype B and F infections in Brazil. AIDS 2006, 20, 763-768.

10. de Souza, A.C.; de Oliveira, C.M.; Rodrigues, C.L.; Silva, S.A.; Levi, J.E. Short communication: Molecular characterization of HIV type 1 BF pol recombinants from Sao Paulo, Brazil. AIDS Res Hum Retroviruses 2008, 24, 1521-1525.

11. Melo, F.L.; Jamal, L.D.; Zanotto, P.M. Characterization of primary isolates of HIV-1 CRF28_BF, CRF29_BF and unique BF recombinants circulating in Sao Paulo, Brazil. AIDS Res Hum Retroviruses 2011.

12. Zhang, M.; Foley, B.; Schultz, A.K.; Macke, J.P.; Bulla, I.; Stanke, M.; Morgenstern, B.; Korber, B.; Leitner, T. The role of recombination in the emergence of a complex and dynamic HIV epidemic. Retrovirology 2010, 7, 25.

13. Carobene, M.G.; Rubio, A.E.; Carrillo, M.G.; Maligne, G.E.; Kijak, G.H.; Quarleri, J.F.; Salomon, H. Differences in frequencies of drug resistance-associated mutations in the HIV-1 
pol gene of B subtype and BF intersubtype recombinant samples. J Acquir Immune Defic Syndr 2004, 35, 207-209.

14. Krauchenco, S.; Martins, N.H.; Sanches, M.; Polikarpov, I. Effectiveness of commercial inhibitors against subtype F HIV-1 protease. J Enzyme Inhib Med Chem 2008, 1.

15. Scott, W.R.; Schiffer, C.A. Curling of flap tips in HIV-1 protease as a mechanism for substrate entry and tolerance of drug resistance. Structure 2000, 8, 1259-1265.

16. Hornak, V.; Okur, A.; Rizzo, R.C.; Simmerling, C. HIV-1 protease flaps spontaneously open and reclose in molecular dynamics simulations. Proc Natl Acad Sci U S A 2006, 103, 915-920.

17. Piana, S.; Carloni, P.; Rothlisberger, U. Drug resistance in HIV-1 protease: Flexibility-assisted mechanism of compensatory mutations. Protein Sci 2002, 11, 2393-2402.

18. Seibold, S.A.; Cukier, R.I. A molecular dynamics study comparing a wild-type with a multiple drug resistant HIV protease: Differences in flap and aspartate 25 cavity dimensions. Proteins 2007, 69, 551-565.

19. Batista, P.R.; Wilter, A.; Durham, E.H.; Pascutti, P.G. Molecular dynamics simulations applied to the study of subtypes of HIV-1 protease common to Brazil, Africa, and Asia. Cell Biochem Biophys 2006, 44, 395-404.

20. Kozisek, M.; Bray, J.; Rezacova, P.; Saskova, K.; Brynda, J.; Pokorna, J.; Mammano, F.; Rulisek, L.; Konvalinka, J. Molecular analysis of the HIV-1 resistance development: enzymatic activities, crystal structures, and thermodynamics of nelfinavir-resistant HIV protease mutants. J Mol Biol 2007, 374, 1005-1016.

21. Ode, H.; Ota, M.; Neya, S.; Hata, M.; Sugiura, W.; Hoshino, T. Resistant mechanism against nelfinavir of human immunodeficiency virus type 1 proteases. $J$ Phys Chem B 2005, 109, 565574.

22. Pardini, M.I.; Jamal, L.F.; Durigon, E.L.; Massad, E.; Perez, J.F.; Pinho, J.R.; Holmes, E.C.; Zanotto, P.M. Boosting virology in Brazil. Plos Biol 2008, 6, 428-429.

23. Hansson, T.; Aqvist, J. Estimation of binding free energies for HIV proteinase inhibitors by molecular dynamics simulations. Protein Eng 1995, 8, 1137-1144.

24. Nunn, A.S.; Fonseca, E.M.; Bastos, F.I.; Gruskin, S.; Salomon, J.A. Evolution of antiretroviral drug costs in Brazil in the context of free and universal access to AIDS treatment. PLoS Med 2007, 4, e305.

25. Sanches, M.; Krauchenco, S.; Martins, N.; Gustchina, A.; Wlodawer, A.; Polikarpov, I. Structural characterization of B and non-B subtypes of HIV-protease: insights into the natural susceptibility to drug resistance development. J Mol Biol 2007, 369, 1029-1040.

26. Sanches, M.; Krauchenco, S.; Martins, N.H.; Gustchina, A.; Wlodawer, A.; Polikarpov, I. Structural characterization of B and non-B subtypes of HIV-protease: insights into the natural susceptibility to drug resistance development. J Mol Biol 2007, 369, 1029-1040.

27. Ode, H.; Matsuyama, S.; Hata, M.; Neya, S.; Kakizawa, J.; Sugiura, W.; Hoshino, T. Computational characterization of structural role of the non-active site mutation M36I of human immunodeficiency virus type 1 protease. J Mol Biol 2007, 370, 598-607.

28. Lisovsky, I.; Schader, S.M.; Martinez-Cajas, J.L.; Oliveira, M.; Moisi, D.; Wainberg, M.A. HIV-1 protease codon 36 polymorphisms and differential development of resistance to nelfinavir, lopinavir, and atazanavir in different HIV-1 subtypes. Antimicrob Agents Chemother 2010, 54, 2878-2885.

29. Dirauf, P.; Meiselbach, H.; Sticht, H. Effects of the V82A and I54V mutations on the dynamics and ligand binding properties of HIV-1 protease. J Mol Model 2010.

30. Clemente, J.C.; Moose, R.E.; Hemrajani, R.; Whitford, L.R.; Govindasamy, L.; Reutzel, R.; McKenna, R.; Agbandje-McKenna, M.; Goodenow, M.M.; Dunn, B.M. Comparing the accumulation of active- and nonactive-site mutations in the HIV-1 protease. Biochemistry 2004, 43, 12141-12151.

31. Clemente, J.C.; Moose, R.E.; Hemrajani, R.; Whitford, L.R.S.; Govindasamy, L.; Reutzel, R.; McKenna, R.; Agbandje-McKenna, M.; Goodenow, M.M.; Dunn, B.M. Comparing the 
Accumulation of Active- and Nonactive-Site Mutations in the HIV-1 Protease $\uparrow$. Biochemistry 2004, 43, 12141-12151.

32. Calazans, A.; Brindeiro, R.; Brindeiro, P.; Verli, H.; Arruda, M.B.; Gonzalez, L.M.; Guimaraes, J.A.; Diaz, R.S.; Antunes, O.A.; Tanuri, A. Low accumulation of L90M in protease from subtype F HIV-1 with resistance to protease inhibitors is caused by the L89M polymorphism. J Infect Dis 2005, 191, 1961-1970.

33. Santos, A.F.; Abecasis, A.B.; Vandamme, A.-M.; Camacho, R.J.; Soares, M.A. Discordant genotypic interpretation and phenotypic role of protease mutations in HIV-1 subtypes B and G. Journal of Antimicrobial Chemotherapy 2009, 63, 593-599.

34. Bandaranayake, R.M.; Kolli, M.; King, N.M.; Nalivaika, E.A.; Heroux, A.; Kakizawa, J.; Sugiura, W.; Schiffer, C.A. The effect of clade-specific sequence polymorphisms on HIV-1 protease activity and inhibitor resistance pathways. J Virol 2010, 84, 9995-10003.

35. Aulicino, P.C.; Holmes, E.C.; Rocco, C.; Mangano, A.; Sen, L. Extremely rapid spread of human immunodeficiency virus type 1 BF recombinants in Argentina. $J$ Virol 2007, 81, 427429.

36. Bello, G.; Aulicino, P.C.; Ruchansky, D.; Guimaraes, M.L.; Lopez-Galindez, C.; Casado, C.; Chiparelli, H.; Rocco, C.; Mangano, A.; Sen, L.; Morgado, M.G. Phylodynamics of HIV-1 circulating recombinant forms 12_BF and 38_BF in Argentina and Uruguay. Retrovirology 2010, 7, 22.

37. Zhang, M.; Schultz, A.K.; Calef, C.; Kuiken, C.; Leitner, T.; Korber, B.; Morgenstern, B.; Stanke, M. jpHMM at GOBICS: a web server to detect genomic recombinations in HIV-1. Nucleic Acids Research 2006, 34, W463-W465.

38. Schultz, A.K.; Zhang, M.; Leitner, T.; Kuiken, C.; Korber, B.; Morgenstern, B.; Stanke, M. A jumping profile Hidden Markov Model and applications to recombination sites in HIV and HCV genomes. BMC Bioinformatics 2006, 7, 265.

39. Liu, T.F.; Shafer, R.W. Web resources for HIV type 1 genotypic-resistance test interpretation. Clin Infect Dis 2006, 42, 1608-1618.

40. Shafer, R.W. Rationale and uses of a public HIV drug-resistance database. J Infect Dis 2006, 194 Suppl 1, S51-58.

41. Kaldor, S.W.; Kalish, V.J.; Davies, J.F., 2nd; Shetty, B.V.; Fritz, J.E.; Appelt, K.; Burgess, J.A.; Campanale, K.M.; Chirgadze, N.Y.; Clawson, D.K.; Dressman, B.A.; Hatch, S.D.; Khalil, D.A.; Kosa, M.B.; Lubbehusen, P.P.; Muesing, M.A.; Patick, A.K.; Reich, S.H.; Su, K.S.; Tatlock, J.H. Viracept (nelfinavir mesylate, AG1343): a potent, orally bioavailable inhibitor of HIV-1 protease. J Med Chem 1997, 40, 3979-3985.

42. Sali, A.; Blundell, T.L. Comparative protein modelling by satisfaction of spatial restraints. $J$ Mol Biol 1993, 234, 779-815.

43. Laskowski, R.A.; Rullmannn, J.A.; MacArthur, M.W.; Kaptein, R.; Thornton, J.M. AQUA and PROCHECK-NMR: programs for checking the quality of protein structures solved by NMR. $J$ Biomol NMR 1996, 8, 477-486.

44. Van Der Spoel, D.; Lindahl, E.; Hess, B.; Groenhof, G.; Mark, A.E.; Berendsen, H.J. GROMACS: fast, flexible, and free. J Comput Chem 2005, 26, 1701-1718.

45. Humphrey, W.; Dalke, A.; Schulten, K. VMD: visual molecular dynamics. J Mol Graph 1996, 14, 33-38, 27-38.

46. Aruksakunwong, O.; Wittayanarakul, K.; Sompornpisut, P.; Sanghiran, V.; Parasuk, V.; Hannongbua, S. Structural and dynamical properties of different protonated states of mutant HIV-1 protease complexed with the saquinavir inhibitor studied by molecular dynamics simulations. J Mol Graph Model 2006, 25, 324-332.

47. Aqvist, J.; Marelius, J. The linear interaction energy method for predicting ligand binding free energies. Comb Chem High Throughput Screen 2001, 4, 613-626.

48. Aqvist, J.; Luzhkov, V.B.; Brandsdal, B.O. Ligand binding affinities from MD simulations. Acc Chem Res 2002, 35, 358-365. 
49. Hansson, T.; Marelius, J.; Aqvist, J. Ligand binding affinity prediction by linear interaction energy methods. J Comput Aided Mol Des 1998, 12, 27-35.

50. Carr, J.K.; Avila, M.; Gomez Carrillo, M.; Salomon, H.; Hierholzer, J.; Watanaveeradej, V.; Pando, M.A.; Negrete, M.; Russell, K.L.; Sanchez, J.; Birx, D.L.; Andrade, R.; Vinoles, J.; McCutchan, F.E. Diverse BF recombinants have spread widely since the introduction of HIV-1 into South America. AIDS 2001, 15, F41-47.

(C) 2011 by the authors; licensee MDPI, Basel, Switzerland. This article is an open access article distributed under the terms and conditions of the Creative Commons Attribution license (http://creativecommons.org/licenses/by/3.0/). 
Figure S1 - $\alpha$-carbon Root Mean Square Fluctuation of each residue after 4 nanoseconds of simulation. Subtype B proteases are colored red and subtype F proteases red. The catalytic triad region is highlighted in red, the flap region in gray and in brown is highlighted the catalytic pocket, as shown by the protease structure above.
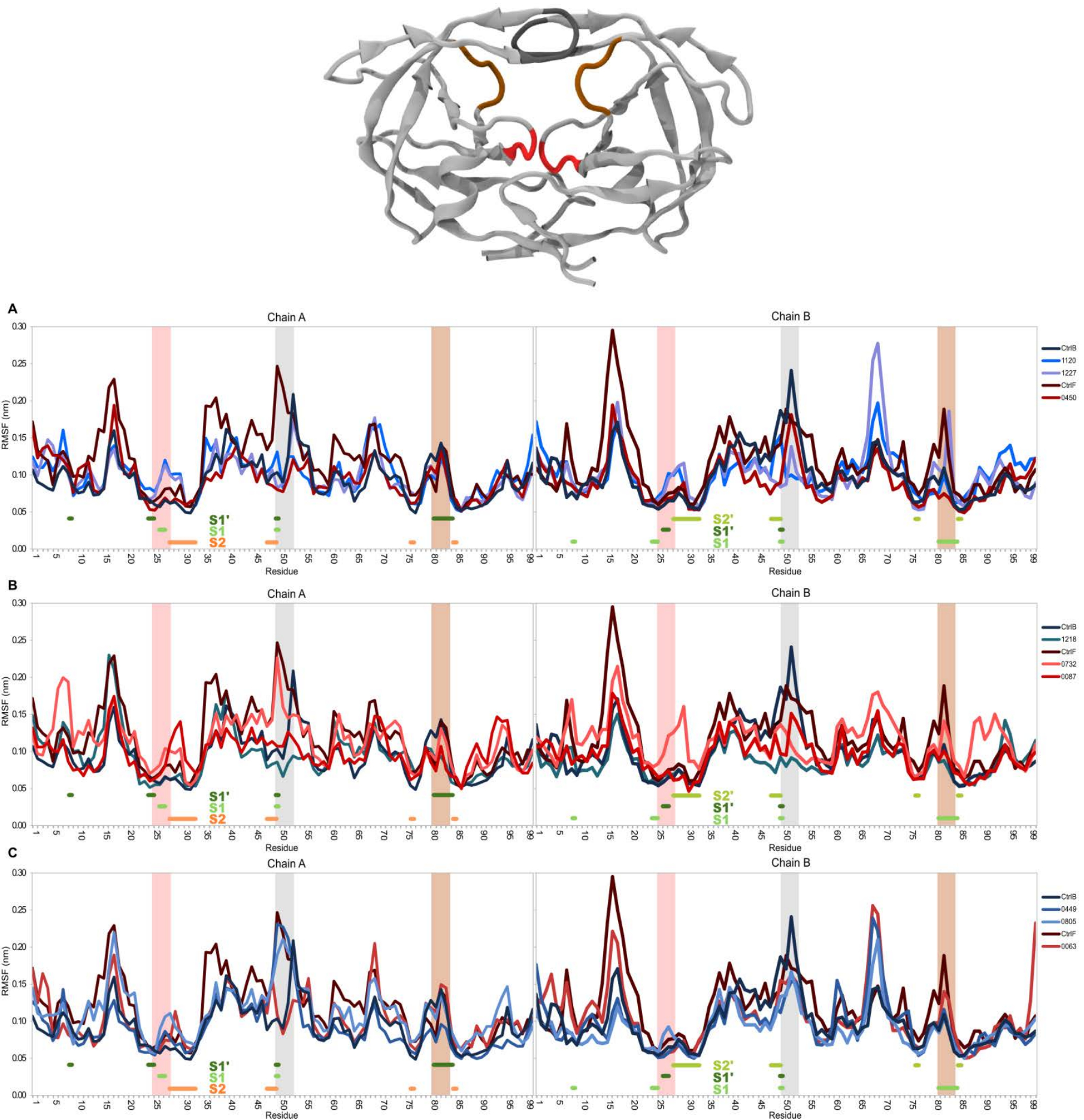


\section{Appendices}

Appendix 1A. Subtype F protease resistance associated mutations and polymorphisms:

Protease 0063: I15V, E35D, M36I, R41K, I54V, R57K, Q61N, L89I, L90M.

Protease 0087: I15V, E35D, M36I, R41K, M46L, R57K, D60E, Q61D, I62V, L63P, V82A, L89M.

Protease 0450: T12K, I15V, L19I, K20R, E35D, M36I, R41K, G48V, I54T, R57K, Q61N, L63A, V82A, L89I.

Protease 0732: T12Q, I15V, K20R, E35D, M36I, N37E, R41K, M46L, R57K, Q61S, V82A, L89M.

Appendix 1B. Subtype B protease resistance associated mutations and polymorphisms:

Protease 0449: T12K, I15V, L19I, K20I, M36I, N37E, M46I, L63P, H69M, I72L, L90M, I93L.

Protease 0805: Q7K, K20I, M36I, N37D, M46I, I54V, K55R, R57K, D60E, I62V, L63P, V82A, L90M.

Protease 1120: E35D, M36I, R41K, I54V, R57K, D60E, Q61D, L63P, I72T, V82A, I93L.

Protease 1218: M36L, M46I, K55R, I54V, I62V, L63P, I72M, V82A.

Protease 1227: I15V, K20M, E35D, M36I, N37E, G48V, I54T, R57K, L63P, I72V, V82A, I93L.

Appendix 1C. Patient drug regimens that included protease inhibitors:

Patient 0063: IDV from Feb/1997 to Nov/1998, RTV/SQV from Nov/1999 to Apr/2000, and NFV from Jun/2000 to Mar/2001 (sampling date);

Patient 0087: IDV from Nov/1996 to Feb/1998, RTV/SQV from Aug/1998 to May/1999, RTV/NFV from May/1999 to Jul/1999, and NFV/IDV from Jul/1999 to Mar/2001 (sampling date);

Patient 0450: SQV from May/1996 to Feb/1998, IDV from Feb/1998 to Jun/2002, and LPV from Jun/2002 to Aug/2003 (sampling date);

Patient 0732: was PI naïve by the time of sampling;

Patient 0449: NFV from May/2000 to Aug/2003 (sampling date);

Patient 0805: SQV at Feb/1997 with unknown duration, NFV from May/1999 to Oct/2001, RTV/IDV from Oct/2001 to Apr/2002, RTV/SQV from Nov/2003 to Jan/2004, and IDV from Jan/2004 to Aug/2004 (sampling date);

Patient 1120: RTV from Aug/1997 to Jul/1998, IDV from Jul/1998 to May/2003, and no PI treatment until sampling date at Aug/2004;

Patient 1218: RTV from Oct/1997 to Sep/1999, LPVr from Dec/2003 to Mar/2004 (sampling date);

Patient 1227: RTV/IDV from Sep/2001 to May/2004, RTV/ATV from Jun/2004 to Aug/2004. 


\section{ANEXO E - Lista de publicações}

de Castro Oliveira JV, de Melo FL, Romano CM, Iamarino A, Rizzi TS, Yeda FP, et al. Structural and phylogenetic relationship of ORF 31 from the Anticarsia gemmatalis MNPV to poly (ADP-ribose) polymerases (PARP). Virus Genes. 2008 Oct;37(2):17784.

Romano CM, de Carvalho-Mello IM, J amal LF, de Melo FL, Iamarino A, Motoki M, et al. Social networks shape the transmission dynamics of hepatitis $\mathrm{C}$ virus. Plos One. 2010;5(6):e11170.

Bello G, Zanotto PM, Iamarino A, Gräf T, Pinto AR, Couto-Fernandez JC, et al. Phylogeographic Analysis of HIV-1 subtype C Dissemination in Southern Brazil. Plos One. 2012;Print.

Iamarino A, de Melo FL, Braconi CT, Zanotto PM. BF Integrase Genes of HIV-1 Circulating in Sao Paulo, Brazil, with a Recurrent Recombination Region. Plos One. 2012;7(4):e34324. 